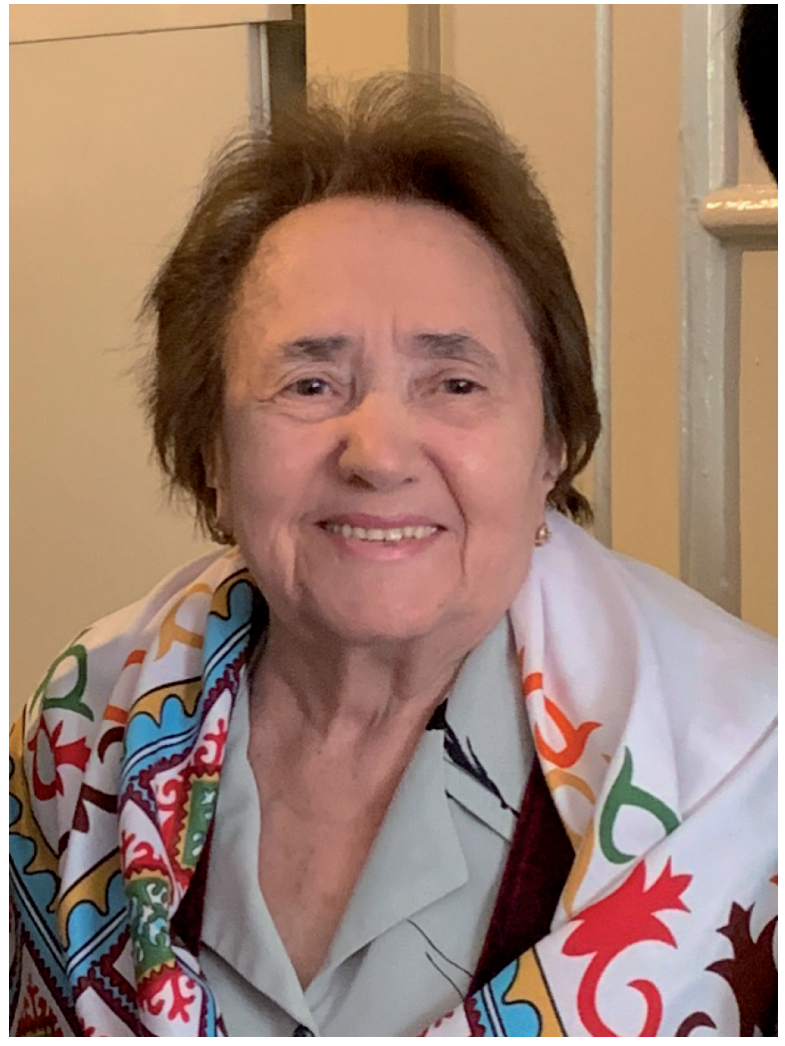

Марина Глебовна Мошкова 


\title{
РАННИЕ КОЧЕВНИКИ ЮЖНОГО УРАЛА И НИЖНЕГО ПОВОЛЖЬЯ
}

\author{
Материалы круглого стола \\ «Археология ранних кочевников евразийской степи: \\ актуальные проблемы и перспективы их решения»
}

К юбилею доктора исторических наук М. Г. Мочковой
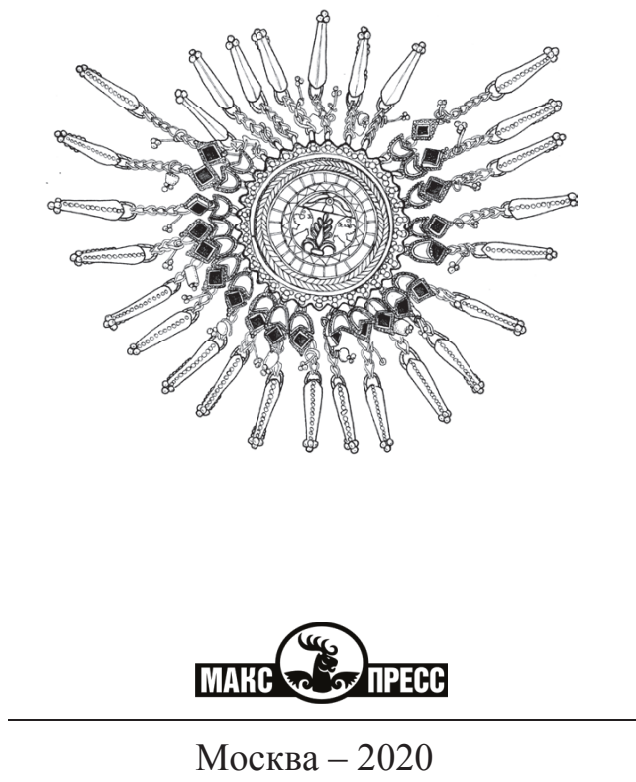


\section{ББК 63.4}

P22

Утверждено к печати Ученым советом

Института археологии Российской академии наук

\section{Ответственный редактор: канд. ист. наук С. В. Сиротин Рецензенты:}

канд. ист. наук С. В. Кузьминых, канд. ист. наук А. Н. Ворошилов

\section{Ранние кочевники Южного Урала и Нижнего Поволжья.}

Р22 Материалы круглого стола «Археология ранних кочевников евразийской степи: актуальные проблемы и перспективы их решения». К юбилею докт. ист. наук М. Г. Мошковой / Институт археологии РАН. - Москва : МАКС Пресс, 2020. - 240 с.

ISBN 978-5-317-06506-5

https://doi.org/10.25681/IARAS.2020.978-5-317-06506-5

В сборнике содержатся материалы круглого стола с международным участием «Археология ранних кочевников евразийской степи: актуальные проблемы и перспективы их решения». Круглый стол состоялся в Институте археологии РАН 12-13 ноября 2019 г. В статьях рассматриваются вопросы, связанные с дискуссионными проблемами истории и археологии ранних ко- чевников Южного Урала и Нижнего Поволжья скифской и сарматской эпохи, а также представлены новые материалы полевых исследований в контексте культурогенеза, погребальной обрядности, хронологии и др.

Издание рассчитано на специалистов в области археологии, истории.

Ключевые слова: археологическая культура, ранние кочевники, скиф-ская, савроматская и сарматская культура, Южный Урал, Нижнее Повол- жье, Предкавказье.

УДК 902/904

ББК 63.4

На обложке и титульном листе приводится изображение подвески из погребения 2 кургана 1 могильника Филипповка 1. Раскопки Л. Т. Яблонского 2013 г. Рисунок К. С. Окорокова 


\section{СОДЕРЖАНИЕ}

Аникеева О.В.

Сакральная символика ювелирного изделия из погребения 2 кургана 1 могильника Филипповка 1........................................ 12

Берлизов Н.Е.

Кости жертвенных животных из савроматских

погребений как индикатор социального положения

погребенного

Гильмитдинова А.Х.

Типы погребальных конструкций как маркеры социальной дифференциации ранних кочевников

Южного Урала второй половины VI-IV вв. до н.э....................... 44

Завьялов В.И., Терехова Н.Н.

Кузнечные артефакты из памятников Скифии и Сарматии

(сравнительный технологический анализ).................................. 54

Канторович А.Р., Маслов В.Е.

Стелы могильника Новозаведенное-III

Клепиков В.М.

Нестандартное клинковое оружие из погребений

IV в. до н.э. в Нижнем Поволжье

81

Краева Л.А.

Систематизация и алгоритм описания

сарматской керамики

Кривочеев М.В.

Южное Приуралье и Нижнее Поволжье

в позднесарматское время. Вопросы взаимодействия 
Лукпанова Я.А.

Сакский компонент в культуре ранних кочевников

Урало-Илекского бассейна VI-IV вв. до н.э.

Льлова Е.В.

К вопросу о датировке спиралевидных височных подвесок

из погребений ранних кочевников Южного Урала

Мышкин В.Н. О дате кургана 3 могильника Филипповка I.... 173

Окороков К.С.

Расшитые бисером рукава женского костюма

из погребения 2 кургана 1 некрополя Филипповка 1

189

Сиротин С.В., Богачук Д.С., Окороков К.С.

Филипповские параллели в погребальном обряде больших

курганов некрополя «Высокая Могила - Студеникин Мар» 203

Сиротин С.В., Богачук Д.С., Окороков К.С.

Позднесарматские комплексы курганной группы

«Высокая Могила» на Южном Урале

Трейстер М.Ю.

Алебастровая статуэтка

из сарматского погребения в Южном Приуралье

228 


\section{ОТ РЕДАКТОРА}

12-13 ноября 2019 г. в Институте археологии РАН состоялся Круглый стол с международным участием «Археология ранних кочевников евразийской степи: актуальные проблемы и перспективы их решения», приуроченный к юбилею д.и.н. М.Г. Мошковой.

Актуальность проведения Круглого стола была связана с тем, что несмотря на активное изучение истории и археологии ранних кочевников (савроматской и сарматской археологических культур) степной Евразии на протяжении XX-XXI века многие вопросы, в числе которых проблемы происхождения культур, хронологии и периодизации, их смены и развития по-прежнему остаются дискуссионными. Активное накопление новых материалов в XXI веке, исследование и доследование таких памятников как Прохоровка, Филипповка, Таксай, Кырык-Оба, Кичигино, Переволочан, Высокая Могила - Студеникин Мар и ряда других привело к постановке новых проблем в изучении савромато-сарматских древностей.

В 2019 году Марина Глебовна Мошкова, д.и.н., главный научный сотрудник Института археологии РАН, отметила юбилей. Закончив в 1955 г. аспирантуру, Марина Глебовна с 1956 г. осуществляет свою научную деятельность в ИА РАН, защитив в стенах Института кандидатскую (1956 г.), а затем и докторскую (1989 г.) диссертации.

Научные интересы Марины Глебовны неразрывно связаны с археологией ранних кочевников евразийских степей - савроматской и сарматскими культурами. 
Необходимо отметить широкую географию полевых работ М.Г. Мошковой. Она принимала участие в экспедиционных работах на Украине, в Дагестане, на территории Нижнего Поволжья, Подонья, Южного Приуралья, Западного Казахстана. Она руководила отрядами в составе экспедиций К.Ф. Смирнова, впоследствии возглавляла Оренбургскую (Южно-Уральскую), Багаевскую, Западно-Казахстанскую экспедиции.

Активную полевую работу М.Г. Мошкова сочетает с плодотворной научной деятельностью. Перу Марины Глебовны принадлежат более 130 научных работ, многие из которых стали классическими в вопросах изучения археологии ранних кочевников.

Помимо этого, следует отметить большую редакторскую работу Марины Глебовны. В 1980-2000-е гг. Марина Глебовна выступает в качестве ответственного редактора многочисленных тематических сборников и монографий.

Отдельного внимания заслуживает работа по подготовке к изданию фундаментальных выпусков из серии «Археология СССР» - «Степи европейской части СССР в скифо-сарматское время», для которого ею были написаны ряд разделов, а также тома «Степная полоса азиатской части СССР в скифо-сарматское время», в котором М.Г. Мошкова выступила в качестве ответственного редактора и соавтора ряда разделов.

Следует сказать, что выход этих двух фундаментальных изданий состоялся, во многом, благодаря усилиям Марины Глебовны.

Помимо научной работы, Марина Глебовна вела активную научно-организационную деятельность. В 1997-1978 гг. - ответственный секретарь журнала Советская археология; 1993-2002 гг. - заведующий Отделом скифо-сарматской археологии; с 1990 г. - член Ученого совета ИА РАН; с 1990 г. - член диссертационного совета ИА РАН; с 1998 г. - член диссертационного совета кафедры архео- 
логии и этнологии исторического факультета МГУ; с 1995 г. - член Редакционного совета журнала «Российская археология».

Будучи заведующим Отделом, Марина Глебовна уделяла особое внимание установлению контактов с региональными археологическими центрами Волго-Уралья, а также содействовала научной подготовке археологов из различных академических учреждений и вузов.

В 2019 г. одной из улиц г. Орска Оренбургской области, в окрестностях которого М.Г. Мошкова проводила активные полевые работы по изучению курганных могильников ранних кочевников присвоено ее имя.

В настоящем сборнике публикуется часть отдельных докладов, представленных на заседаниях Круглого стола.

Всего в работе Круглого стола приняли участие 27 исследователей из научных и образовательных учреждений России (Москва, Волгоград, Ростов-на-Дону, Симферополь, Воронеж, Самара, Екатеринбург, Оренбург, Уфа, Челябинск), а также из Германии и Казахстана.

В представленных докладах в рамках Круглого стола обсуждались вопросы, связанные с современным состоянием проблем сарматской археологии.

Прозвучали доклады, посвященные научной и образовательной деятельности М.Г. Мошковой (Корякова Л.Н., Хабдулина М.К., Таиров А.Д., Медведев А.П.). В докладах А.Д. Таирова, Я.А. Лукпановой, М.К. Хабдулиной, А.Р. Канторовича. В.Е. Маслова, С.В. Сиротина, Д.С. Богачук, К.С. Окорокова, Д.В. Мещерякова были представлены новые материалы из раскопок элитных комплексов ранних кочевников Южного Урала и Предкавказья.

Часть докладов (В.Н. Мышкин, С.В. Сиротин, Н.С. Савельев, Е.В. Лылова) затрагивала вопросы, связанные с хронологией раннекочевнических древностей. В.Н. Мышкиным подробно 
рассмотрен комплекс конского снаряжения из кургана 3 могильника Филипповка 1 в рамках хронологии, как отдельных вещей, так и кургана в целом. Савельевым Н.С. и Сиротиным С.В. был представлен доклад о керамическом комплексе могильников Переволочан I и Переволочан II в контексте хронологии памятников. Е.В. Лылова в своем докладе рассмотрела хронологию одного из типов серег, найденных в богатых комплексах ранних кочевников Южного Урала.

Отдельным категориям вещевого инвентаря были посвящены доклады М.Ю. Трейстера, Л.А. Краевой, В.М. Клепикова, О.В. Аникеевой, В.П. Глебова, А.В. Дедюлькина. М.Ю. Трейстером рассмотрена интересная находка уникальной алебастровой фигурки из детского погребения кургана 1 могильника Нижняя Павловка-І из Южного Приуралья. Л.А. Краевой были затронуты вопросы истории изучения и классификации керамики ранних кочевников Южного Урала. В.М. Клепиковым был представлен доклад, посвященный анализу двух савроматских воинских погребений IV в. до н.э. из раскопок в Астраханской области с нестандартным клинковым оружием. О.В. Аникеевой было рассмотрено уникальное ювелирное изделие, найденное в захоронении знатной женщины (погребение 2) в кургане 1 могильника Филипповка 1 на Южном Урале. В.П. Глебовым и А.В. Дедюлькиным были рассмотрены вопросы современного состояния проблемы так называемых ритуальных кладов.

В докладе А.Х. Гильмитдиновой было предложено рассматривать типы погребальных конструкций как маркеры социальной дифференциации раннекочевнического общества. Вопросы, связанные с реконструкцией женского костюма по материалам элитного погребения из могильника Филипповка 1 были изложены в докладе К.С. Окорокова. Доклад С.И. Лукьяшко был посвящен видам охоты у ранних кочевников Ев- 
разии. В докладе М.В. Кривошеева были отражены проблемы взаимодействия кочевников Южного Приуралья и Нижнего Поволжья в позднесарматское время. В.В. Кропотовым были освещены актуальные вопросы изучения раннесарматских памятников Северного Причерноморья.

В целом, в ходе работы Круглого стола был затронут широкий круг вопросов, связанных с актуальными проблемами археологии ранних кочевников. В ходе развернувшихся дискуссий были обсуждены вопросы хронологии, культурной атрибуции опорных комплексов ранних кочевников Волго-Уралья, различные точки зрения по отдельным проблемам, вопросы классификации и типологии инвентаря и ряд других.

В заключительных выступлениях участники подчеркнули своевременность проведенного Круглого стола, отметили актуальность представленных в докладах вопросов, а также обозначили новые проблемы для обсуждения на мероприятиях, посвященных савромато-сарматской тематике. 


\section{O.В. Аникеева}

\section{Сакральная символика ювелирного изделия из погребения 2 кургана 1 могильника Филипповка 1.}

Резюме. Статья посвящена публикации уникального ювелирного изделия, найденного в нетронутом грабителями захоронении знатной женщины раннесарматского элитного могильника на Южном Урале. Анализ контекста предмета в погребении и технологии его изготовления позволили реконструировать способы крепления и назначения предмета. Он служил драгоценной реликвией, которая могла использоваться только кратковременно в религиозных церемониях и ритуальных практиках.

Поиски аналогий образам, представленным на центральном медальоне, позволили уточнить их семантику и предложить смысловую нагрузку составленной композиции. Ее центральным персонажем является священное дерево, охраняемое божественной силой «khvarenah», представленного в двух ипостасях - крылатого солнечного диска и священных птиц Veraghna. В медальоне применяется новоассирийская композиционная схема, которая появляется в начале IX в. до н.э. и широко распространяется в VIII-VII вв. до н.э. на территориях Урарту и доахеменидской Мидии. Находка реликвии в раннекочевническом погребении IV в. до н.э. свидетельствует о широкой преемственности древнеиранских религиозных культов, которые продолжают существовать в сатрапиях ахеменидского Ирана, воспринимаются элитой сарматских племен Южного Приуралья и распространяются в кочевнической среде. 
Ключевые слова: ранние кочевники Южного Приуралья, могильник Филипповка 1, ювелирное изделие, техники изготовления, способы крепления, композиция и образы медальона.

\section{O.V. Anikeeva \\ Sacral symbolism of jewelry from grave pit 2 burial mound 1 in Filippovka 1 cemetery.}

Abstract. The article is dedicated to the publication of the unique jewelry which was found in the unrobed elite femail grave-pit of the Early Sarmatian burial ground (Southern Urals). The burial context of item convincingly showed that this item was not worn as a decoration in social life, but it was the precious relic used in religious ceremonies and ritual practices very briefly. A detailed study of manufacturing technology allows us to reconstruct the fastening ways and application methods for this jewelry.

The established analogies of medallion images made it possible to clarify its compositional semantics. The sacred tree is placed in the center of the medallion. It is guarded by the divine power of «khvarenah» deity. "Khvarenah" is presented by two guises - the winged sun disc and the sacred Veraghna birds. The general ritual meaning reflects the idea of increasing fertility, ensuring the well-being and multiplying of the offspring, health, wealth and prosperity of the family. New Assyrian compositional scheme used in the medallion. It appeared at the beginning of the IX century BC and actively spread in Urartu and pre-Achaemenid Media since the VIII-VII centuries BC. This relic was found in the early nomadic burial site dating back to the IV century BC. All these show the significant continuity of ancient Iranian religious cults. They continue to exist in the satrapies of Achaemenid Iran, they are perceived by the elite of the Sarmatian tribes of the Southern Urals and they spread in a nomadic environment. 
Keywords: South Urals early nomads, Filippovka 1 cemetery, disk-shaped jewelry, constraction, fastening method, imagery composition, medallion plot

При доследовании в 2013 г. царского кургана 1 могильника Филипповка 1 Приуральской археологической экспедицией ИА РАН под руководством Л.Т. Яблонского было обнаружено нетронутое грабителями захоронение женщины (35-40 лет) (Яблонский, 2014. С. 6). Оно располагалось под восточной полой кургана вблизи края насыпи, имело прямоугольную в плане форму и общие размеры 3,6 × 2,6 м. Длинной осью могила была ориентирована в направлении края насыпи кургана в данном секторе. Глубина ямы составляла 3,7 м. На уровне погребенной почвы, вдоль южной стенки и в заполнении южного сектора могильной ямы, были зафиксированы крупные остатки бревен деревянного перекрытия погребальной камеры. Погребённая лежала на спине, головой в южный сектор, в вытянутом положении на спине. По совокупности необычайно богатого и типологически разного сопровождающего инвентаря захороненная женщина обладала высоким социальным статусом (Яблонский, 2014. С. 5-6; Аникеева и др., 2017. С. 5, 11; 2018. С. 211-212).

Среди разнообразных украшений выделяется сложное ювелирное изделие с дисковидным медальоном в центре, обрамленным разнообразными подвесками (Яблонский, 2016а. С. 748749; Yablonsky, Treister, 2019. Р. 748-749). Всестороннему исследованию этого предмета посвящена эта работа.

Когда мы работаем с предметами из погребений, то предполагаем, что сопровождающий погребенных инвентарь до определенной степени отражает их функции и социальный статус при жизни. Это только предположение, поскольку в могиле порядок и расположение инвентаря определял не сам погре- 
бенный, а другие люди, собиравшие инвентарь в соответствии с тем, что они знали о его использовании при жизни. Поэтому все построения и интерпретации, высказанные ниже, сделаны исходя из контекста рассматриваемого погребения, анализа образов, присутствующих в его декоре, особенностями конструкции, позволяющими предложить способ использования.

Дисковидное изделие (рис. 1), которому посвящена эта работа, находилось в пределах большого короба в изголовье слева от погребённой. Изделие лежало лицевой стороной диска вниз, все подвески на цепочках, обрамляющие края центрального диска, были аккуратно закинуты на оборотную сторону диска (Яблонский, 2016а. С. 748-749; Аникеева и др., 2018. С. 212-213; Yablonsky, Treister, 2019. Р. 123-126). В ряде статей его положение указано между коробом и черепом погребенной (Яблонский, 2015. С. 100-101; Яблонский, 2016а. С. 748-749; 2016б. С. 15; Аникеева и др., 2017, С. 9-10; 2018, С. 212-213; Yablonsky, Treister, 2019, Р. $123-$ 126). Однако мы определенно можем говорить, что оно лежало в коробе. Об этом свидетельствуют характерное комковатое заполнение и сохранившиеся сверху фрагменты деревянного перекрытия, которые аналогичны заполнению и хорошо сохранившимся фрагментам конструкции короба. Это единственное ювелирное изделие, которое не было надето на погребенной, поэтому логично предположить, что оно не предназначалось для украшения элементов одежды, а использовалось кратковременно в определенных ритуалах. Остальное время оно бережно хранилось в коробе вместе с разнообразными культовыми предметами.

Подробный анализ технологии изготовления и конструкции ювелирного изделия был проведен в предыдущей работе (Аникеева, Яблонский, 2019в. С. 50-57) под руководством и при активном участии реставратора высшей категории по изделиям из металла М. В. Нацким (ГОСНИИР, Москва), за что автор 
приносит ему глубокую благодарность. Поэтому в рамках данной статьи я остановлюсь подробнее на конструкции крепления изделия (п. 1), поскольку вопрос о том, для чего предназначался этот предмет, во многом определяется тем, как он крепился, а так же тем, каким образом его было принято носить. Далее приведу характерные признаки, выявленные при технологическом анализе, на которых базируется предложенная в работе модель использования изделия:

1. В центре оборотной стороны диска медальона припаяны четыре крепежные скобы из золотой полосы (1,3 × 0,3 см), образующие каре, которые в центральной части профиля имеют отступ в форме арки для крепления (рис. 3). Под двумя скобами, расположенными по вертикали относительно изображения на медальоне, видны царапины и потертости одного направления, которые отсутствуют на двух боковых скобах. Трасология царапин, проведенная М. В. Нацким, показывает, что они были сделаны заостренным предметом типа «швейной» иглы. Тогда пришивание изделия проводилось преимущественно за две дужки, фиксирующие вертикальное расположение центрального медальона.

2. Семь коротких цепочек (рис. 2; 3) в верхнем секторе диска прикреплены изнаночной (оборотной) стороной, украшающие их подвески видны, только если они перекинуты на лицевую сторону медальона, в этом положении их концевые подвески закрывают изображение крылатого солнечного диска в верхнем ярусе медальона.

3. Петли для крепления цепочек (расположены радиально вдоль фестончатого края диска, под пирамидками зерни) припаяны к основе диска одним концом, второй конец оставлен не припаянным для свободного надевания/снимания цепочек. Это подразумевает возможность изменения положения цепочек вдоль диска.

По мнению М.В. Нацкого, с точки зрения традиционной 
ювелирной техники единственным рациональным положением предмета являлось его стационарное горизонтальное крепление к верхнему торцу вертикального стержня за четыре скобы оборотной стороны диска. Конструкция крепежных петель допускает пришивание, притягивание ремешками, использование штифтов и т.п., поэтому и сам стержень мог быть из плотной ткани, кожи, дерева, металла. Это оправдывает большой диаметр колец петель диска, позволяющий элементам свободно раскачиваться. Вертикальное, относительно композиции, крепление центрального медальона он считает неэстетичным, так как при этом положении верхние цепочки-подвески будут не видны при откидывании их назад. Если перекинуть их вперед, нижние привески цепочек закроют изображение медальона. Цепочки не смогут стабильно удерживаться на лицевой стороне из-за конструкции петель. Также в стационарном вертикальном положении они должны оставлять явные следы потертостей на композиции медальона, которые по данным трасологического анализа не выявлены. Боковые цепочки с кастами, бусинами и концевыми подвесками при этом перепутаются.

М.Ю. Трейстер также предлагает горизонтальное крепление украшения, так как полагает, что форма скоб крепления подразумевают крепление предмета к мягкой основе. Он считает маловероятным, что украшение являлось навершием жезла, так как в этом случае способ его крепления к жесткой основе (камень, дерево, металл) был бы иным (не уточняя каким). На этом основании он определил предмет как навершие, которым украшался головной убор (Yablonsky, Treister, 2019. Р. 123).

Отметим, что М.В. Нацкий и М.Ю. Трейстер однозначно считают, что предмет использовался в стабильном (зафиксированном в определенной позиции) положении и служил навершием для украшения вертикального стержня/посоха или головного убора. 
Если допустить, что предмет использовался кратковременно, в постоянном движении, согласно сценарию ритуалов, цель которых заключалась во взаимодействии подвижных цепочек/подвесок с персонажами композиции медальона: они могли скрывать и полностью открывать изображение или частично перекрывать определенный элемент композиции в зависимости от производимых движений. Важно, что в ходе церемонии позиция медальона постоянно изменялась.

Зафиксировано, что семь коротких цепочек сверху крепятся к медальону оборотной стороной. Привески на них играют, только если они перекинуты на лицевую сторону медальона, при этом они закрывают изображение крылатого солнечного диска в верхнем ярусе медальона, акцентируя внимание на дереве и двух птицах в центре. Изменение бокового угла наклона позволяет длинным боковым цепочкам перекрывать фигуру одной из птиц. Это возможно при наклонно/вертикальном положении диска. Кратковременность использования объясняет отсутствие потертостей, которые появились бы на диске при трении цепочек о медальон при постоянном вертикальном положении предмета. Большой диаметр крепежных петель диска позволяет цепочкам свободно перемещаться при движении и согласуется с результатами трасологического анализа поверхностей крепления изделия, показывающими, что пришивание изделия неоднократно проводилось за две дужки, фиксирующие вертикальное расположение медальона.

Таким образом, в зависимости от сценария религиозной церемонии, предмет мог крепиться в определенном участке тела человека, ведущего этот сценарий, горизонтально (на плече или голове) или вертикально (на груди, спине или руке), в ходе церемонии его позиция постоянно менялась. При этом трасология следов крепления предмета показывает большую вероятность вертикально/наклонного крепления, а дошедшее до нас распо- 
ложение цепочек (п. 2) показывает, что сценарий культа включал закрывание/открывание крылатого диска в верхнем ярусе медальона. Очевидно, целью культовых действий являлось то или иное взаимодействие с основными персонажами, представленными на композиции центрального медальона украшения и олицетворяющих то или иное божество.

Рисунок полихромного медальона (рис. 1) выполнен в технике перегородчатой инкрустации (клуазонне). По внутреннему краю медальона расположены две окружности. Одну составляют четырехугольные ячейки: шаг орнамента определяется цветом вставок - синяя-бирюзовая-красная-бирюзовая. Вторая окружность с треугольными ячейками, которые по цвету образуют два кольца: внешнее - с чередующимися синими и красными треугольниками, внутреннее - из бирюзовых треугольников. Центральная композиция представлена двумя ярусами, разделенными горизонтальной перегородкой. В верхнем ярусе на бирюзовом трапециевидном основании помещено изображение крылатого солнечного диска. Отметим, что диск изображен с помощью двух кольцевидных перегородок, диаметр которых уменьшается к центру, который фиксирован центральной точкой. В центре нижнего яруса расположено мировое древо, выполненное также из красного и бирюзового стекла. Оно стоит на основании бирюзового цвета. Его красные серповидные корни симметричны и опущены вниз. Голубой удлиненный ромбический ствол окаймлен ветвями/листьями бирюзового и красного цвета. По бокам древо охраняют две птицы, выполненные из плоских золотых пластин. Изображения симметричные, профильные: голова, хвост и крыло каждой птицы повернуты от центра к краю диска, туловище изогнуто и расположено по контуру древа жизни. Лапы птиц сверху опираются на дуги корней, головы остроклювые, показано отставленное в сторону крыло 
с загибающимся вверх концом. Обрезанный по прямой линии конец хвоста направлен вниз. На голове гравировкой выделены круглые глаза, на шее - фрагменты оперения.

М.Ю. Трейстер, анализируя сюжет композиции, однозначно относит изображение крылатого диска к символике верховного ахеменидского бога Ахура Мазды и на этом основании относит композицию к ахеменидским религиозным сюжетам. Упоминая изображение пальметты при описании, он опускает семантику изображения (что объяснимо, так как в ахеменидских сюжетах подобная иконография пальметты/дерева не известна, а ее иные изображения являются вторичными элементами композиции, разделяющими ее центральные сцены). Проводя параллели сюжету среди вещей ахеменидского круга, он приводит изображение на верхнем фризе из пекторали, найденной, предположительно, в районе Ардебиль на северо-западе Ирана и датирующейся первой третью IV в. до н.э., где симметричные фигуры птиц изображены по бокам фигуры Ахура Мазды, а крылатый диск отсутствует (Yablonsky, Treister, 2019. Р. 125-126).

Л.Т. Яблонский считал, что «в центре украшения изображено мировое древо с охраняющими его крону мифологическими птицами симургами, частично покрытыми рыбьей чешуей. Корни дерева уходят в подземный мир. Венчает композицию распростершая крылья главная птица симург - охранительница» (Яблонский, 2014. С. 5).

Образ «мирового (космического) древа» («древа жизни», «древа плодородия») появляется в глиптике северной Месопота-

\footnotetext{
* Автор выражает глубокую и искреннюю благодарность Колгановой Галине Юрьевне (научному сотруднику отдела истории и культуры Древнего Востока Института востоковедения РАН, старшему научному сотруднику отдела Древнего Востока ГМИИ им. А.С. Пушкина) за сотрудничество, советы и предоставленную литературу при интерпретации образа мирового древа и его смысловой нагрузки в ритуальных практиках.
} 
мии в III тыс. до н.э. и распространяется в странах восточного Средиземноморья во II тыс. до н.э. (Michaux-Colombot, 2008. P. 349. Pl. $I, 1,2,8,10,17,20$. P. 350. Pl. II, 28. Fig. 14, A-E). О семантике и иконографии стилизованного дерева в искусстве Месопотамии написано много (укажем лишь Giovino, 2007). Этот образ соотносится с общей моделью брачных отношений и - шире - с преемственной связью поколений: в ветвях мирового древа плодились души людей, спускавшиеся затем птицами на землю, чтобы войти в чрево женщин этого рода. Таким образом, все три яруса мирового древа (вершина, ствол и корни) и связанные с ними три класса животных по-своему отражают идею зачатия и плодородия. Горизонтальная структура мирового древа образуется самим деревом и объектами по сторонам от него. Отчётливее всего она обнаруживается в связи со стволом. Если вертикальная структура дерева связана со сферой мифологического, прежде всего, космологического, то горизонтальная структура взаиморасположения и окружения дерева соотнесена с ритуалом и его участниками. Вся последовательность элементов по горизонтали воспринимается как сцена ритуала, основная цель которого обеспечение благополучия, плодородия, потомства, богатства. Сам же ритуал может трактоваться как прагматическая реализация мифа, проекция «мифологического» в сферу «ритуального».

Важно, что ритуальные схемы, связанные с мировым древом олицетворяли для древних процессы мирообразования: 1) исходное положение - мир в любой момент может разрушиться в хаосе; задача ритуала - интегрировать космос из составных частей жертвы; 2) жрец произносит текст и совершает движения по сценарию ритуальной практики (над жертвой на алтаре или в сакральном месте вблизи другого образа дерева жизни, символизирующего сакральный центр мира); 3) обращение к мировому дереву как образу вновь воссозданного порядка с молитвами и просьбами. 
Таким образом, дерево жизни выступает как посредствующее звено между вселенной (макрокосмом) и человеком (микрокосмом) и является местом их пересечения. Образ священного дерева гарантировал целостный взгляд на мир и определение человеком своего места во вселенной.

Образ священного дерева зафиксирован практически повсеместно в Ассирии и Урарту. Примененная схема - дерево, фланкируемое фигурами (в данном случае хищных птиц), с крылатым солнечным диском в изголовье - типично новоассирийская. Ее истоки уходят в начало II тыс. до н.э., что для нас в данный момент не так важно как то, что такая композиционная схема вошла в моду с первой половины IX в. до н.э. (Пиотровский, 1959. С. 228, 238-240, 248-254; Giovino, 2007. Figs. 1, 13-16, 22, 37-38, 56; Batmaz, 2013. Р. 71 83. Figs. 11-15, 17-19, 25, 26, 28, 38). Она активно тиражировалась в VIII-VII вв. до н.э. благодаря глиптике и тканям, композиции вышивок на которых сохранили для нас новоассирийские рельефы. Территория Урарту, являлась плацдармом для распространения ассирийской изобразительной схемы со стилизованным (священным) деревом. Яркий пример - найденная на Кармир-Блуре стеатитовая шкатулка. На ее круглой крышке изображено священное дерево, окруженное фигурами крылатых гениев с птичьими головами; над деревом помещен крылатый солнечный диск, а по краю шкатулки - орнамент из переплетающихся окружностей с точкой в центре (Пиотровский, 1959. С. 188; 1970. Илл. 98).

Иконография дерева на филипповском медальоне отличается от ассирийской и урартской изобразительной системы. Образ на филипповском медальоне сильно стилизован (см. выше), что, очевидно, отражает процесс активного тиражирования образа на поздней стадии в сатрапиях Ахеменидского Ирана. Аналогов ему среди ассирийских или урартских изображений не найдено. Наиболее близкой аналогией является дерево с девя- 
тью ветвями на серебряной чаше, по данным А. Судавар происходящей из западного Ирана и датированной поздним VII в. до н.э. (Soudavar, 2018. Р. 26. Fig. 22). Очевидно, количество ветвей на дереве было обусловлено символикой проводимого ритуала. Преобладает изображение деревьев с девятью ветвями, деревья с семью ветвями встречаются реже (Michaux-Colombot, 2008. P. 249. Pl. I, 17; Batmaz, 2013. P. 71, 73, 77. Figs. 11, 17, 19, 28a).

На филипповском медальоне изображение крылатого солнечного диска связано, безусловно, не с ахеменидской символикой Ахура Мазды, так как иконография диска совершенно иная. Он изображен в форме трех окружностей с уменьшающимися к центру диаметрами. Это символика абстрактного божества Хварна (Хварно, Фарр), обозначаемое «khvarenah (khvarnah)» и являющееся символом божественной силы (обеспечивающую фортуну), «дарующую сияние (славу), божественную благодать великому (правителю, герою) и сопровождающую его пока он справедлив (беспристрастен)» (Kia, 2016, р. 211). Его популярность была особенно высока у иранских племен доахеменидского периода на территории Мидии. Исходя из анализа религиозной символики в ахеменидской иконографии, его популярность по-прежнему велика в сатрапиях ахеменидского Ирана.

Для Ахеменидского периода характерно сотрудничество между жрецами различных племен, отличающихся по религиозным воззрениям. И Геродот, и Страбон упоминают традиционные религиозные различия между персидскими и мидийскими жрецами. Они сообщают, что у иранцев не было храмов или святынь, и они молились на открытом воздухе или на вершине горы (Геродот, История I.131; Страбон, XV3.13). Этот тип поклонения также показан в иконографии Ахеменидов, особенно в ритуальных сценах на гробницах персидских царей после Дария. Несмотря на свои ранние политические разногласия со жреца- 
ми, персидские цари держали их на службе, а некоторые из них занимали административные должности. Жрецы иногда проявляются в искусстве ахеменидского периода. Хорошим примером является рельеф из Даскилиона в Малой Азии, на котором изображены два иранских жреца, один из которых, очевидно, без бороды, стоит перед храмом с головами жертвенного быка и барана, установленными на алтаре. В одной руке они держат усики (барсомы), а другая поднята в знак молитвы. Их носы и рты покрыты нижней частью их тюрбанов. У магов была традиция прикрывать рты, когда они стояли перед священным огнем, чтобы спасти его от загрязнения своим дыханием. Та же традиция существует сегодня среди зороастрийских священников, которые покрывают свои рты куском ткани, называемой падам. Барсим/барсом является еще одним свидетельством того, что священники участвуют в ритуале/церемонии (Curtus, Tallis, 2005. P. 152. Fig. 57. Р. 153).

В рельефах дворца в Персеполе изображены люди, одетые таким образом, поднимающиеся по лестницам дворцов с едой и животными (Curtus, Tallis, 2005. Cat. 40, 47): эти фигуры ранее считались слугами. На фрагменте глазурованного кирпича из раскопок дворцрвого комплекса в Сузах изображен безбородый жрец в белом головном уборе (Curtus, Tallis, 2005. Cat. 54). Это важно, так как белый цвет был характерен для священников в иранской религии. Есть также другой пример того же головного убора в черном цвете, но это может быть признаком священника более низкого ранга.

Интерпретируя символику и назначение птиц, изображенных по бокам сакрального дерева, мы обратились к источникам, где упоминается священная птица. В арийской традиции Шьена/ Саэна-Симург помещался на вершине «мировой горы», что позволяет связать его образ с тем или иным вариантом «мирового древа», поскольку «мировое древо» находилось на вершине «мировой горы» в верованиях индийцев и иранцев. На филиппо- 
вском медальоне обе птицы отвернулись от дерева, контуры их ног и спины параллельны стволу дерева, мощные лапы стоят на корнях дерева, отогнутые в сторону хвосты внизу замыкаются на внешнем бортике медальона, а макушки голов смыкаются с концами крыльев крылатого диска.

Таким образом, ствол и листья дерева вписаны в замкнутое пространство, сверху закрытое размахом крыльев солнечного диска, с боков ограниченное замкнутыми контурами птичьих фигур. Не исключено, что они несут смысловую нагрузку, связанную с изображением крылатого диска, но совершенно отчетливо проявляется их значение как хранителей священного дерева.

В Персеполе найдена табличка с изображением птицы, иконография которой идентична изображениям на филипповском медальоне (Soudavar, 2005. P. 127. Fig. 12.8), но ее поза отличается: с распростертыми крыльями и расставленными лапами с тройственным изображением священной сферы «khvarenah» две в расставленных лапах и одна в изголовье. Согласно легенде, отраженной в Авесте, птица из семейства соколиных по имени Veraghna являлась с одной стороны хранительницей святыни, с другой стороны - только она могла, как приносить сияние «khvarenah», так и забрать его.

Подводя итог проведенному исследованию, надо сказать, что анализ контекста представленного ювелирного изделия в погребении и выявленных особенностей его технологии изготовления и конструкции убедительно показали, что предмет не носился как украшение в повседневной/светской жизни, а служил драгоценной реликвией, которая могла использоваться только кратковременно в религиозных церемониях и ритуальных практиках.

Конструкция предмета - круглый диск, обрамленный радиально расходящимися вертикальными подвесками, представляет символику древнеиранского солярного культа, а сам пред- 
мет олицетворял солнце. Наиболее близкие к диску подвески в форме месяца, вероятно, относятся к лунной символике.

Определенная композиция персонажей в филипповском медальоне показывает, что ее центральным персонажем является священное дерево, охраняемое божественной силой древнеиранского божества Хварны (khvarenah/khvarnah), представленного в двух ипостасях - крылатого диска и священных птиц Veraghna. Мы можем определить общий смысл ритуалов, в которых участвует священное дерево, отражающих идею преумножения плодородия во всех его проявлениях: обеспечении благополучия и преумножения потомства, здоровья, богатства и преуспевания рода.

Использованная в медальоне композиционная схема - новоассирийская. Она появилась в начале IX в. до н.э. и активно распространяется, начиная с VIII-VII вв. до н.э., в Урарту и, вероятно, в доахеменидской Мидии.

Находка этой уникальной реликвии в раннекочевническом погребении, датирующимся в пределах IV в. до н.э., свидетельствует не только о широкой преемственности религиозных постулатов, продолжающих существовать в сатрапиях ахеменидского Ирана, но и об их распространении в кочевнической среде, прежде всего среди элиты сарматских племен Южного Приуралья.

\section{ЛИТЕРАТУРА}

Аникеева О.В., 2019. Производство ювелирных украшений у ранних кочевников Южного Приуралья: инструменты и процесс обработки драгоценных камней // Ювелирное искусство и материальная культура: сб. науч. ст. СПб: Изд-во ГосЭрмитажа. С. 7-16.

Аникеева О.В., Шемаханская М.С., Яблонский Л.Т., 2017. Ювелирные шедевры ахеменидской эпохи из гробницы знатной 
женщины в Южном Приуралье // Ювелирное искусство и материальная культура: сб. науч. ст. СПб: Изд-во Гос. Эрмитажа. С. 5-11.

Аникеева О.В., Нацкий М.В., Немаханская М.С., Яблонский Л.Т., 2018. Ювелирные украшения из погребения знатной женщины (могильник Филипповка 1 курган 1 погребение 2) // Маргулановские чтения-2018: сб. матер. Междунар. науч.-практ. конф. «Духовная модернизация и археологическое наследие» (г. Актобе, 19-20 апреля 2018 г.). Алматы; Актобе. С. 211-219.

Аникеева О.В., Яблонский Л.Т, 2019а. Элементы погребального костюма жрицы из филипповских курганов: материалы к реконструкции // Археология евразийских степей. № 1. С. 12-32.

Аникеева О.В., Яблонский Л.Т., 2019б. Техника изготовления ювелирных украшений из погребения 2 кургана 1 могильника Филлиповка-1 и вероятные центры изготовления // УАВ. Т. 19. № 1. С. $48-62$.

Пиотровский Б.Б., 1959. Ванское царство (Урарту). М.: Издво Восточной литературы. 283 с.

Яблонский Л.Т., 2014. Новые находки в «царском» кургане 1 могильника Филипповка 1 (предварительное сообщение) // КСИА. Вып. 232. С. 3-7.

Яблонский Л.Т., 2015. Новые необыкновенные находки из кургана могильника Филипповка 1 // Археология, этнография и антропология Евразии. Т. 43. №2. С. 97-108.

Яблонский Л.Т., 2016а. Новые археологические данные об ахеменидских влияниях на Южном Урале // ВДИ. Т. 76. № 3. С. 744-766.

Яблонский Л.Т., 2016б. Об одном аспекте социальной роли женщины в раннекочевом сообществе Южного Приуралья (по материалам могильника Филипповка 1) // Кадырбаевские чтения-2016: сб. матер. Междунар. науч. конф. (г. Актобе, 6-7 октября 2016 г.). Актобе. С. 15-18.

Batmaz A.A., 2013. New Ceremonial Practice at Ayanis Fortress: 
The Urartian Sacred Tree Ritual on the Eastern Shore of Lake Van // Journal of Near Eastern Studies. Vol. 72. № 1. P. 65-83.

Curtus J., Tallis N., 2005. Forgotten empires. The world of ancient Persia. London: the British Museum press. 272 p.

Giovino M., 2007. The Assyrian Sacred Tree: A History of Interpretation. Fribourg: Academic Press. 243 p.

Kia M., 2016. The Persian Empire: A Historical Encyclopedia. Empires of the World. Santa-Barbara: ABC-CLIO. Vol. I. 397 p.

Michaux-Colombot D., 2008. The royal Hittite title 'My Sun' and the Winged Sun Disk // 38. ICANAS. Religion. Vol. 1. International Congress of Asian and North African Studies. Ankara: Atatürk Kultür, Dil Ve Tarih Yüsek Kuramu. P. 329-353.

Soudavar A., 2005. The formation of Achaemenid imperial ideology and its impact on Avesta // Eds. J. Curtus, St.J. Simpson. The world of Achaemenid Persia. London; New York: I.B. Taurisp. P. 111-138.

Soudavar A., 2018. Iranian complexities: a stude in achaemenid, avestian, and sasanian controversies. Houston: SOUDAVARHouston. 234 p.

Yablonsky L.T., Treister M.Yu., 2019. New archaeological data on achaemenid influences in the southern Urals // Ancient civilizations from Scythia to Siberia. Vol. 25. P. 79-161.

\section{СВЕДЕНИЯ ОБ АВТОРЕ.}

Аникеева Ольга Викторовна, канд. геол.-минерал. наук, Государственный научно-исследовательский институт реставрации, Москва, Россия, e-mail: olganikeeva@yandex.ru 


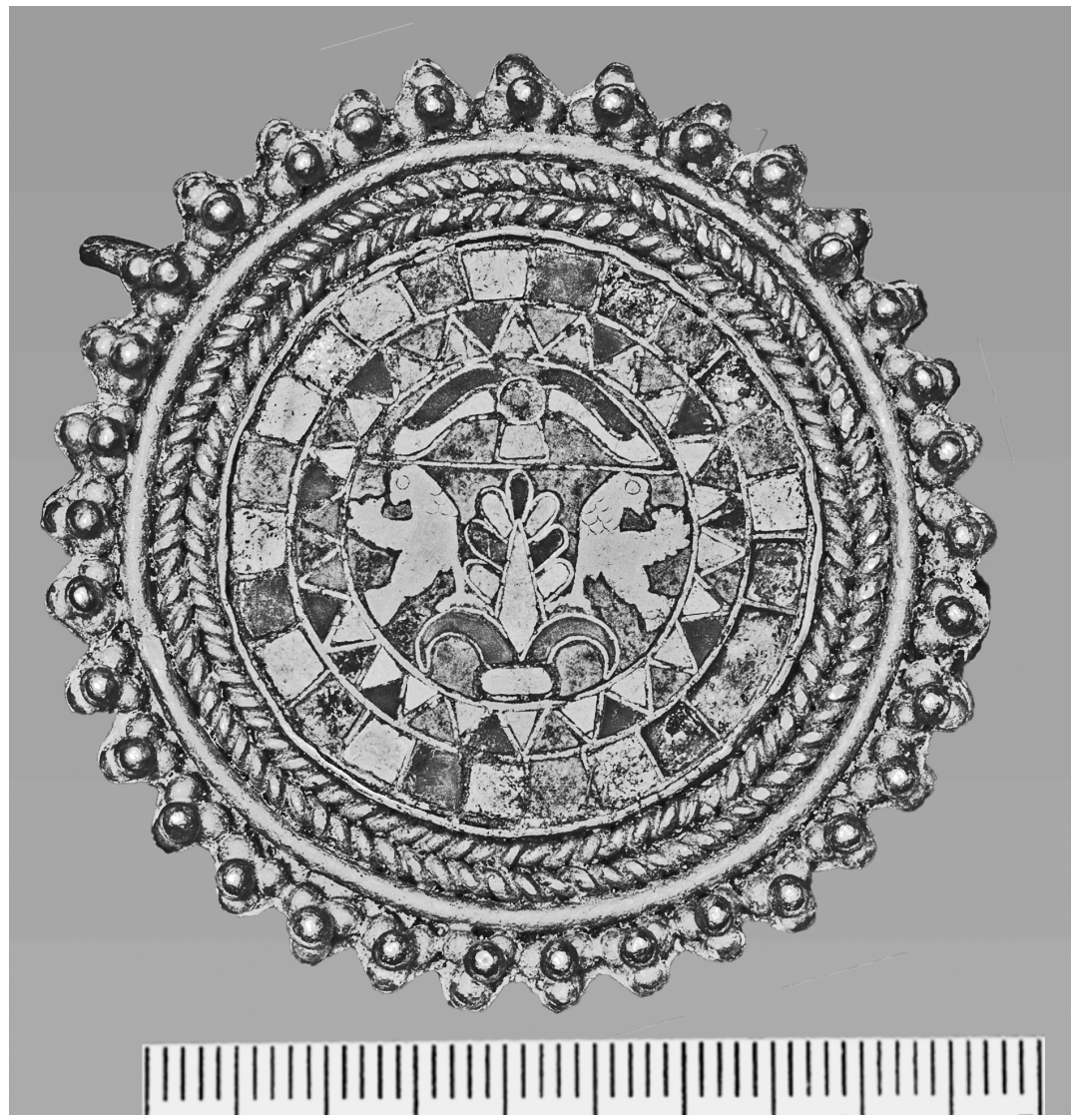

Рис. 1. Могильник Филипповка 1 курган 1 погребение 2. Центральный медальон ювелирного изделия. 


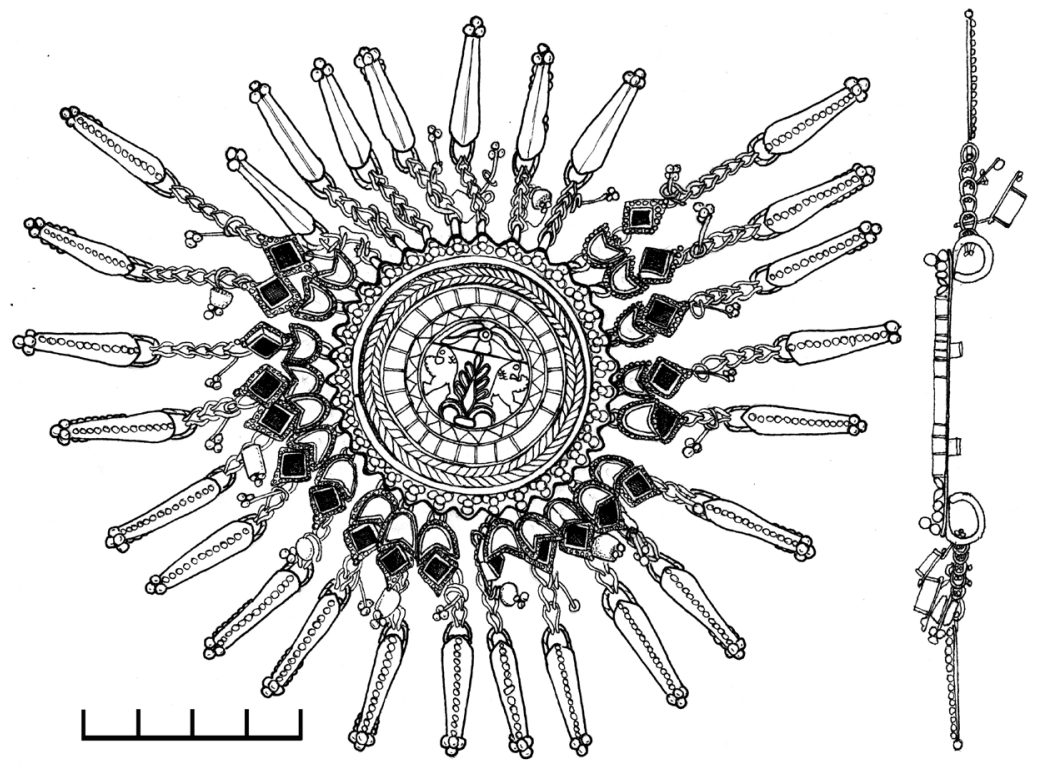

Рис. 2. Могильник Филипповка 1 курган 1 погребение 2. Ювелирное изделие - подвеска, лицевая сторона. ОГИКМ 20283/4 


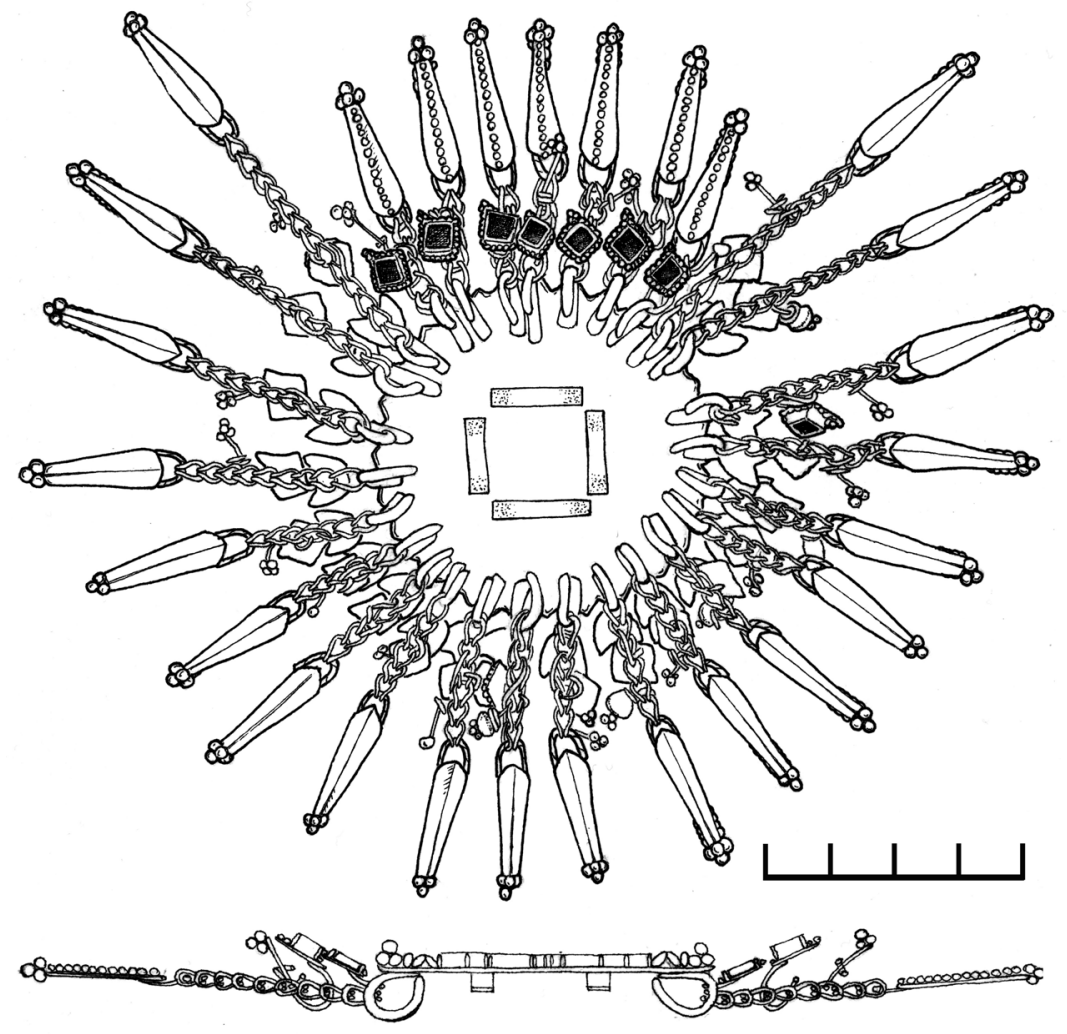

Рис. 3. Могильник Филипповка 1 курган 1 погребение 2. Ювелирное изделие - подвеска, оборотная сторона. ОГИКМ 20283/4 


\section{Н.Е. Берлизов}

\section{Кости жертвенных животных из савроматских погребений как индикатор социального положения погребенного}

Резюме. Статья посвящена выявлению археологических критериев для определения статуса погребенных савроматской археологической культуры. Опираясь на ведийскую погребальную традицию, автор предлагает считать одним из индикаторов общественного положения в савроматском обществе видовую принадлежность жертвенных животных. Многомерный анализ погребальных памятников савроматской культуры конце VII - начале III вв. до н.э. подтверждает эту гипотезу. Кости жертвенных быков и лошадей находят, обычно, в элитных погребениях, кости овец - в менее статусных. Не содержат костей жертвенных животных погребения с самым скромным погребальным обрядом.

Ключевые слова: погребальный обряд, жертвоприношения, животные, социальное положение

\section{N.E. Berlizov \\ The bones of sacrificial animals from the Savromat burials as an indicator of the social status of the buried.}

Abstract. The Article is devoted to the identification of archaeological criteria for determining the status of buried Sauromatian archaeological culture. Based on the Vedic burial tradition, the author proposes to consider one of the indicators of social status in sauromatian society species of sacrificial animals. Multivariate 
analysis of the burial monuments of the Sauromatian culture of the late VII - early III centuries BC confirms this hypothesis. The bones of the sacrificed bulls and horses find, usually in elite burials, the bones of a sheep - less status. Burials without bones of sacrificial animals are distinguished by the most modest funeral rite.

Keywords: funeral rites, sacrifices, animals, social status

Интерпретация тех, или иных деталей погребальных обрядов древности всегда является крайне сложным и уязвимым этапом в работе археолога, так как во многом зависит от полноты знаний о мифологии и религиозных представлениях носителей той, или иной культуры. В тех случаях, когда такая информация отсутствует, либо является неполной, исторические реконструкции реализуются на основе «здравого смысла» и реалий сегодняшнего дня, что далеко не всегда справедливо в отношении древних обществ. Так при определении социального статуса погребенного принято обращать внимание на состав погребального инвентаря, а также на объем трудозатрат на погребальное сооружение.

Вместе с тем, судя по данным письменных источников, такие признаки далеко не всегда могут служить точным критерием статуса погребенного. Так, Солон, стараясь снизить социальную напряженность в Афинах, запретил устраивать слишком пышные похороны, устраивать во время погребения гекатомбы и помещать погребённому более трёх одежд (Plut. Solon. XXI). Следовательно, фиксируемый археологически погребальный ритуал в Афинах постсолоновской эпохи, должен демонстрировать, как минимум, меньшую имущественную дифференциацию афинского общества, чем в досолоновскую, хотя в реальности разрыв в доходах и влиянии афинских пентакосиомедимнов и фетов сохранялся в прежних масштабах. Ведийский погребальный обряд предусматривал 
при погребении кшатриев, составлявших, как известно, варну воинов и правителей, помещать их на погребальный костер, либо в могилу, с оружием и золотыми украшениями. Но в ходе прощания с умершим и то, и другое у мертвого изымалось и передавалось его живым родственникам (РВ. X. 18. 9; АВ. XVIII. 2. 59-60; 4. 56). Погребальный обряд сторонников мировых религий также не всегда позволяет адекватно оценивать прижизненный социальный и имущественный статус погребённого. Эти соображения делают актуальными любые сообщения источников о реальных статусных отличителях в древних погребальных практиках.

Е.Е. Кузьмина обратила внимание на фрагмент из Шатапатха-Брахманы, согласно которому в зависимости от варны умершего, варьировал вид животного, приносившегося в жертву покровителю дорог Пушану: при погребении брахмана жертвовали чёрную корову, похоронам кшатрия соответствовал конь, а вайшьи - коза или баран (Кузвмина, 1986. С. 76). Таким образом, кости жертвенных животных в погребении ведийского арьи могут дать информацию о статусе покойного.

Учитывая, что авторы и почитатели Вед изначально входили в то самое праиндоиранское объединение, из которого вышли и скифы, и савроматы, и сарматы, можно предположить, что верования и ритуалы последних могут быть близки индоарийским. При этом некоторые погребальные практики савроматов и сарматов находят удовлетворительное объяснение именно в ведийских верованиях (Берлизов, 2018). Следовательно, кости жертвенных животных, в принципе, могут быть индикаторами социального статуса погребенного и у савроматов с сарматами.

Для проверки этой гипотезы было решено уточнить роль жертвенной пищи в погребальном обряде савромато-сарматской культуры на разных её этапах. Ниже мы коснемся савроматских древностей. 
Методы фактор- и кластер- анализа позволили установить, что в кон. VII-VI вв. до н.э. (Фаза А савромато-сарматской АК - Берлизов, 2011) савроматские погребения междуречья Дона и Волги не содержат кости КРС. Кости лошади и МРС в них встречаются, причём в эпоху савроматской архаики они никогда не сочетаются в одном погребении. Кости МРС в целом встречаются гораздо чаще, чем кости лошади (соответственно 13 и 3 случая из выборки в 31 погребение). Наличие, либо отсутствие костей жертвенной лошади, либо овцы в этот период коррелирует с характером надмогильного сооружения, числом погребенных в одной могиле, планом могильной ямы, наличием/отсутствием подсыпок в могиле, положением рук погребенного, наличием/отсутствием золотых и/или серебряных бляшек, шильев, створчатых раковин, культовых сосудов, ножей, лежащих с костями жертвенных животных, красящих веществ и костей редких животных.

Можно отметить, что архаические савроматские погребения, не содержавшие костей животных, впущены в курганы эпохи бронзы. Весьма разнообразно положение рук погребенных. Они всегда являются одиночными, совершались в прямоугольных ямах, на дне которых может встречаться посыпка мелом. В них отсутствуют золотые и серебряные бляшки, шилья, створчатые раковины, и, естественно, ножи, лежащие с костями жертвенных животных.

Погребения, сопровождающиеся костями МРС, обычно, впущены в насыпи эпохи бронзы, но могут быть и основными под курганом. Они всегда одиночные. Совершались в прямоугольных и квадратных ямах, на дне которых могут фиксироваться следы мела, огня или охры. Положение рук усопших варьирует, хотя в меньшей степени, чем в погребениях без костей жертвенных животных, В них иногда встречаются золотые бляшки, шилья, 
створчатые раковины; ножи, лежащие с костями жертвенных животных; сосуды с красками; красная, чёрная и синяя краски. Только в них, помимо овечьих, встречены кости сайги.

Кости коня чаще встречены в основных погребениях под курганами в прямоугольных ямах, подсыпки на дне ям отсутствуют. Эти погребения могут быть и индивидуальными, и парными. Верхние конечности покойных, обычно, вытянуты вдоль туловища. Погребения, обычно, содержат бляшки из драгоценных металлов, створчатые раковины, шилья и ножи, лежащие с костями жертвенных животных, белую либо красную краски.

Прослеженные комбинации элементов обряда позволяют говорить о том, что в конце VII-VI вв. до н.э. носители савроматской культуры дифференцировано подходили к составу жертвенной пищи. Крупный рогатый скот в этот период в жертву не приносился. Изредка приносили в жертву коней, причем, лицам, имевшим право на индивидуальную курганную насыпь, помещение в могилу золотых украшений и предметов, традиционно считающихся атрибутами культа. Можно отметить достаточную каноничность конструкции могилы и позы погребённых.

Более «демократичным» жертвенным животным оказывается овца, кости которой встречаются чаще конских. Погребения, сопровождавшиеся костями овец, как правило, отличаются более скромным обрядом. Они чаще являются впускными, у них варьирует конструкция могилы и поза погребенного, в них почти не встречаются золото и атрибуты культа, характерные для захоронений, содержавших кости лошади, хотя могут встречаться кости иных животных, не входящих в «стандартный» набор.

Наконец, погребения, в которых отсутствуют останки жертвенных животных, оказываются самыми скромными: они всегда впускные, у них крайне неустойчиво положение рук, в них отсутствуют золотые украшения и атрибуты культа. 
Для савроматских древностей конце VI - начале III вв. до н.э. (Фаза В савромато-сарматской АК) вновь наблюдается определенная взаимосвязь породы жертвенных животных и статусных особенностей обряда.

В Задонье в этот период наличие в погребении костей КРС, лошади, либо МРС связано с конструкцией погребального сооружения, наличием подсыпок и следов огня в погребении, наличием/отсутствием амфор, золотых и серебряных кубков или обкладок деревянных сосудов, древкового оружия, деталей упряжи из драгоценных металлов, золотых или серебряных бляшек и украшений, гривен и шкатулок.

Выяснилось, что кости КРС являются самой редкой находкой, они сопровождали 4 погребенных из учтенных 161, причем встречены только в мужских погребениях. Только для погребенного с костями КРС была построена монументальная каменная гробница (8 Пятибратний курган у ст. Елисаветовской). Именно для погребений с костями КРС характерны находки кубков и обкладок сосудов из драгоценных металлов и древковое оружие. Только в погребениях с костями КРС, либо с костями коня встречены амфоры, элементы упряжи из драгоценных металлов, золотые бляшки и детали одежды, гривны, шкатулки.

В погребениях, куда кости жертвенных животных не помещались, либо помещались только кости МРС, перечисленные выше детали обряда не фиксируются.

Сделанные наблюдения показывают, что савроматы Задонья, при похоронах которых приносили в жертву КРС, либо коня, явно обладали более высоким общественным статусом, нежели остальные. При этом наиболее статусные детали обряда характерны для мужских погребений, сопровождавшихся костями КРС.

Анализ комплексов конца VI-V вв. до н.э. из Заволжья показывает, что с видовой принадлежностью жертвенных животных связаны характер надмогильного сооружения; план и раз- 
рез могильной ямы; количество погребённых в могиле; особые случаи в позе погребенного; число сосудов с погребенным; наличие/отсутствие метательного, древкового, либо клинкового оружия; элементов упряжи; бус; бляшек из драгоценных металлов; некоторых элементов утвари; амулетов; ножа, лежащего с костями жертвенных животных. Можно отметить, что вошедшие в данный перечень элементы погребального инвентаря (предметы вооружения, утвари, украшения и атрибуты культа), всегда рассматривались как индикаторы социального статуса погребенных. И вновь мы наблюдаем дифференциацию этих элементов в соответствии с присутствием, либо, наоборот, отсутствием в погребении останков тех или иных жертвенных животных.

Комплексы, содержащие кости КРС вновь являются редкостью (4 из 43). Они либо основные в курганах, либо впущены в насыпи «своей» культуры и совершены в простых прямоугольных, либо квадратных ямах с вертикальными стенками и горизонтальным полом. Могут быть индивидуальными и коллективными. Поза погребенных всегда стандартна. Только в этих погребениях встречается более 1 сосуда. В них могут встречаться значительные наборы наконечников стрел, наконечники копий и акинаки, бляшки от конского очелья, бусы, подвески из кабаньих клыков и ножи с костями жертвенных животных. В погребении с костями КРС могут находиться и кости принесенных в жертву коней (Блюменфельд А12). Вместе с тем, золотые бляшки, элементы утвари в них отсутствуют.

Погребения с костями жертвенных коней в савроматских курганах Заволжья также редки (3 случая, причём в двух встречены также кости КРС). Единственное погребение, содержавшее кости коня не в наборе с костями КРС (Солодовка III к. 2 п. 3) было основным под курганом, совершено в овальной яме с вертикальными стенками и горизонтальным полом. Следы постпогребального 
нарушения костяка не фиксируются. В нем обнаружены наконечники стрел, акинак, ворворка, нож с костями лошади. Керамика, детали упряжи, золотые бляшки, бусы, амулеты отсутствуют.

Кости овцы сопровождают обычно погребения, впущенные в насыпи эпохи бронзы, либо эпохи железа, еще реже - основные. Погребения индивидуальные, реже - парные, совершались в прямоугольных ямах (в т.ч. с диагональным положением костяка) с вертикальными стенками и горизонтальным полом. В них зафиксировано разрушение верхней части костяка без ограбления. Погребенных сопровождает не более 1 сосуда, не более 3 наконечников стрел, изредка - акинаки, но встречаются золотые бляшки и кремни. Древковое оружие, детали упряжи, амулеты, ножи с костями жертвенных животных - отсутствуют. Интересно, что в Заволжье кости овцы не сочетаются с костями других животных.

Вновь скромно выглядят погребения, не содержавшие костей жертвенных животных. Они всегда впущены в более ранние насыпи, совершены на древнем горизонте, в прямоугольных, либо овальных ямах с вертикальными стенками и горизонтальным полом. Погребения индивидуальные и парные. Следы постпогребального нарушения костяка не фиксируются. В них помещали не более 1 сосуда и не более 3 наконечников стрел. Клинковое и древковое оружие, детали упряжи, золотые украшения, амулеты, ножи с костями жертвенных животных - отсутствуют.

Итак, погребения с костями КРС и коня вновь выделяются из общей массы и своей редкостью, и сравнительным богатством инвентаря.

В Приуралье в конце VI - начале III вв. до н.э. в савроматских погребениях видовая принадлежность жертвенных животных коррелирует с наличием/отсутствием деревянной гробницы, посыпок на дне могилы, способом обращения с погребенным (кенотаф, ингумация, кремация), его ориентировкой, 
количеством сосудов с погребенным, наличием/отсутствием золотых или серебряных обкладок деревянных сосудов, клинкового оружия, деталей упряжи, золотых украшений, терочников.

Кости КРС редки и здесь (13 комплексов из 224). Они могут встречаться в деревянных гробницах, стоящих на древнем горизонте, либо над большой ямой. На дне погребального сооружения могут встречаться следы огня, иногда в сочетании с меловой посыпкой. Все погребения, содержавшие кости КРС совершены только по обряду ингумации. Ориентировка погребенных в основном колеблется между западной и юго-западной. В погребениях с костями КРС сосуды либо отсутствуют, либо встречается 1 сосуд, либо более трех. В составе инвентаря фигурируют золотые обкладки деревянных сосудов; кинжалы, иногда в сочетании с мечом; трочные пряжки и бляшки от конского очелья, ворворки; бляшки, украшающие колчан; тёрочники. С костями КРС в погребении могут сочетаться конские и бараньи кости.

Несколько чаще встречаются кости жертвенных коней (35 комплексов). Они могут находиться в деревянных гробницах, стоящих на древнем горизонте, либо над небольшой ямой. На дне погребальной камеры могут фиксироваться меловая посыпка, следы огня, иногда - в сочетании. Кости коня фиксируются и в ингумациях, и в кремациях. Помимо западной и юго-западной ориентировки выражены южная, юго-восточная и восточная. Погребальный инвентарь близок тому, который встречается в погребениях с костями КРС, но количество сосудов может быть любым (от 1 до 3 и более), могут встречаться золотые украшения (серьги, браслеты).

Комплексы, содержащие кости МРС еще более многочисленны (90 комплексов). Они могут сочетаться с костями КРС и/или коня и встречаются в деревянных гробницах и построенных на древнем горизонте, и стоявших над большими и малыми ямами. На дне погребальных камер фиксируются посыпки мелом, уголь- 
Н.Е. Берлизов.

ками, следы огня. Кости МРС встречаются как с ингумациями, так и с кремациями. Сектор ориентировок погребенных близок тому, который прослежен в погребениях, содержавших конские кости. Количество сосудов в погребениях варьирует так же, как и в предыдущей группе. В них так же могут помещаться металлические обкладки деревянных сосудов, клинковое оружие, детали упряжи, золотые и серебряные украшения, терочники. Бляшки могут располагаться не только на колчане, но и на груди погребенных.

Погребения, не содержавшие костей жертвенных животных, самые многочисленные. Помимо обычных ям, они встречаются в деревянных гробницах, стоящих на древнем горизонте. На дне могил могут фиксироваться посыпки мелом, угольками, следы огня. Отсутствие костей жертвенных животных может фиксироваться и в ингумациях, и в кремациях. При общем сходстве сектора ориентировок с остальными группами несколько чаще встречается положение погребенных головами на север, северо-запад и северо-восток. В таких погребениях встречается не более 3 сосудов, отсутствуют металлические сосуды и обкладки сосудов, трочные пряжки, никогда не сочетаются вместе меч и кинжал. Бляшки могут встречаться в области шеи погребенного, на ножнах, либо в заполнении могилы. Отсутствуют серебряные украшения (хотя могут быть золотые) и терочники.

Уральская выборка вновь демонстрирует редкость захоронений с костями КРС и коней, а также общую скромность обряда погребений, не содержащих костей жертвенных животных. Можно отметить, что погребения с костями жертвенных животных у ранних кочевников Южного Урала отличаются от остальных наличием терочников, которые можно рассматривать как атрибуты культа: песты и терочники («давильные камни») упоминаются в «Ригведе» и «Атхарваведе» как инструменты для выжимания сомы (PB. I. 28. 1, 4; I. 83. 6; I. 135. 7; IV. 3. 3; VII. 35. 7; IX. 86. 3; X. 100. 9; AB.V. 22. 1; VI. 3. 2; VI. 49. 3; IX. 6. 1. 15; IX. 6. 2. 27; XIX. 10. 7). 
Эти наблюдения позволяют, как нам кажется, сделать вывод о статусном характере заупокойной пищи в погребениях савроматского круга. Судя по всему, к элитным стоит относить комплексы, содержащие кости КРС и коня. Вероятно, ниже был статус у лиц, на похоронах которых приносили в жертву овец. Наконец, еще ниже мог быть социальный статус погребенных, с которыми не обнаруживаются кости жертвенных животных. Можно предполагать, что у ранних савроматов Нижнего Дона конца VII-VI вв. до н.э. лидирующее положение в обществе занимали индивиды, на похоронах которых приносили в жертву коня. В конце VI начале III вв. до н.э. это положение, вероятно, переходит к лицам, при погребении которых приносили в жертву быка или корову. Можно также осторожно предположить наличие неких четырех стратов в обществе номадов Задонья-Приуралья скифской эпохи.

Эту особенность стоит учитывать и при определении статуса ограбленных погребений, и при попытках реконструкции социального устройства общества ранних кочевников Задонья-Приуралья скифского времени.

\section{ЛИТЕРАТУРА}

Берлизов Н.Е., 2011. Ритмы Сарматии. Савромато-сарматские племена Южной России в VII в. до н.э. - V в. н.э. Ч.1. Краснодар: Парабеллум. 320 с.

Берлизов Н.Е., 2018. Материалы к интерпретации погребальных практик савроматов и сарматов // VIII «Анфимовские чтения» по археологии Западного Кавказа. Война и торговля как факторы исторического развития народов Западного Кавказа в древности и средневековье: Материалы международной археологической конференции (г. Анапа, 30 мая - 1 июня 2018 г.) / Отв. ред. Р.Б. Схатум, В.В. Улитин. Краснодар: ИП Шлепнев М.В. С. 24-30. 
Кузъмина E.E. , 1986. Древнейшие скотоводы от Урала до Тянь-Шаня. Фрунзе: Илим. 133 с.

\section{СПИСОК СОКРАЩЕНИЙ}

АВ - Атхарваведа

РВ - Ригведа

\section{СВЕДЕНИЯ ОБ АВТОРЕ.}

Берлизов Николай Евгеньевич, кандидат исторических наук, Краснодарский государственный институт культуры, Краснодар, Россия, e-mail: berlizov@mail.ru 


\section{А.Х. Гильмитдинова \\ Типы погребальных конструкций как маркеры социальной дифференциации ранних кочевников Южного Урала второй половины VI-IV вв. до н.э.}

Резюме. В статье проводится анализ типов погребальных конструкций в захоронениях ранних кочевников Южного Урала второй половины VI-IV вв. до н.э. Всего проанализировано 392 погребения из 216 курганов. Целью исследования является выявление типов погребальных конструкций, дифференцирующих группы населения ранних кочевников по социальному статусу. Для достижения поставленной цели была проведена работа по выявлению социально-значимых признаков погребального обряда, нашедших свое отражение в захоронениях с разными типами внутримогильных конструкций. В рамках работы рассмотрены погребения, совершенные в катакомбах, подбоях, ямах с дромосом и в простых грунтовых ямах. В результате, из всех рассмотренных типов погребений, дромосные и деревянные конструкции наиболее ясно отражали высокий социальный статус умерших.

Ключевые слова: ранние кочевники, Южный Урал, погребальный обряд, кочевая элита, социальная организация. 


\section{A. Kh. Gilmitdinova \\ Types of burial structures as markers of social differentiation of early nomads of the Southern Urals in the second half of the $6^{\text {th }}-4^{\text {th }}$ centuries $\mathrm{BC}$.}

Abstract. The article analyzes the types of burial structures in the graves of the early nomads in the Southern Urals during the second half of the 6 - 4 centuries BC. In total 392 burials from 216 mounds were analyzed. The aim of the study is to identify the types of burial structures that differentiate the groups of early nomads according to their social status. To achieve this goal, we identify socially significant signs of the funeral rite, which are reflected in burials with the different type of constructions. Burials with the following types of burials are considered: catacombs, pits with special niches (podboi) constructed on the longitudinal wall, pits with a dromos and simple pits. As a result, the burials with a dromos and pits with wooden constructions reflected the high social statues of the dead most clearly.

Key words: Early Nomads, South Urals, funeral rite, nomadic elite, social organization.

Считается, что социальное положение умерших могло отражаться в различных формах погребального обряда, и его изучение позволяет проводить социологические реконструкции древних обществ. Неотъемлемой частью погребального обряда являются конструктивные и планиграфические особенности над- и внутримогильных сооружений, благодаря которым возможно не только исследование погребальных традиций древнего населения, его миграций и изучение культурных связей, но также выявление признаков социального неравенства. 
Целью исследования является выделение типов погребальных конструкций, дифференцирующих группы населения ранних кочевников Южного Урала второй половины VI-IV вв. до н.э. по социальному статусу.

Достижение цели невозможно без выполнения задач, заключающихся: 1) в изучении набора признаков погребального обряда, отражающих социальную дифференциацию ранних кочевников; 2) в анализе типов могильных ям, встречающихся в памятниках второй половины VI-V вв. до н.э. и конца V-IV вв. до н.э.; 3) в соотнесении типов могильных ям с известными критериями богатства.

Основная проблема реконструкции социальной структуры ранних кочевников заключается в большом количестве ограбленных памятников. Интерпретировать разграбленные погребения в социальном ключе, опираясь только на анализ остатков инвентаря, представляется не совсем корректным. В связи с этим появляется необходимость в разработке методов изучения социальной структуры ранних кочевников по погребальному обряду, в том числе и по типам погребальных конструкций.

Известно, что погребальный обряд несет в себе информацию о различных сторонах структуры общества, и важной задачей при его исследовании является выявление отдельных признаков, которые можно соотнести с различными сферами социальной структуры древнего населения (Бунятян, 1982. C. 138). Поэтому при изучении погребального обряда ранних кочевников, был рассмотрен набор признаков, включающий в себя: 1) объем насыпей курганов (в м³); 2) типы погребальных конструкций; 3) положение погребений в кургане относительно центра; 4) форму могильных ям; 5) ориентировку могильных ям; 6) размер и глубину могильных ям; 7) количество погребенных в захоронении. 
В рамках исследования было изучено 216 курганов, в которых было выявлено 392 погребения. К периоду второй половины VI-V вв. до н.э. относилось 158 погребений, к концу V-IV вв. до н.э. - 234 захоронения.

К анализу привлечены погребения из памятников: Филипповка I, II, Переволочан I, II, Кырык-Оба II, Канакас-2, Ялчикаево II, Три Мара, Первая, Вторая и Третья группы Аландских курганов, Пятимары I, Тара-Бутак, Близнецы, Увак, Мечетсай, Чумарово, Уязыбашево, Булатово, V Комсомольский, III Сагитово, IV Тавлыкаево, Ивановский I, III, IV, Елбулак-Тамак, Альмухаметово, Новый Кумак, Лебедевка II, IV, V, VI, VII и VIII, Шиханы, а также из Бурибайских, II Сибайских, Казанкинских, Булатовских, Авласовских курганов, и из погребальных памятников у пос. Целинный, одиночных курганов Яковлевка II, VI, VIII и Байгускаровского кургана.

В ходе исследования были получены следующие результаты.

1) Согласно энергозатратной модели, применяемой для анализа социальной организации через погребальную сферу, наиболее явным признаком кочевой элиты является размер курганной насыпи (Tainter, 1978. Р. 105-141). Памятники ранних кочевников имеют общую тенденцию к небольшим объемам насыпей (от 1 до $100 \mathrm{~m}^{3}$ ). Среди памятников второй половины VI-V вв. до н.э. наибольшим оказался курган 1 из могильника Покровка 2 (1770,3 м³, диаметр: 66 х 54 м; высота: 2,5 м) с разграбленной центральной грунтовой ямой. Достаточно крупными размерами отличались памятники конца V-IV вв. до н.э. с центральными дромосными погребениями (Филипповка I, к. 1 - 16953,5 м³, диаметр: 120 м; высота: 7 м; к. 4 - 11211,9 м³ диаметр: 80 м; высота: 8 м). Хотя в вопросе определения элитного статуса памятника не оспаривается значимость трудовых затрат на его сооружение, тем не менее, согласно некоторым исследователям, большие раз- 
меры курганов не всегда являются показателем захоронений социальной верхушки общества. К категории элитных могут относиться памятники и с небольшой насыпью, но в том случае если в них обнаружены предметы из драгоценных металлов, считавшиеся в эпоху ранних кочевников показателями социального престижа (Сокровища.., 2008).

2) Ямы с погребальными конструкциями чаще встречаются в выборке памятников конца V-IV вв. до н.э. (52,3\%), чем второй половины VI-V вв. до н.э. (35\%). Наиболее распространенным типом внутримогильных конструкций в погребениях второй половины VI-V вв. до н.э. являются деревянные перекрытия (47,3\%). Среди захоронений конца V-IV вв. до н.э. нередки подбои (42,3\%) и ямы с дромосом $(32,5 \%)$. В этот же период появляются ямы с заплечиками и подбойно-катакомбные конструкции (Сиротин, 2015. С. 781-783).

3) Прямоугольная и овальная формы ям являлись преобладающими в захоронениях на протяжении двух рассматриваемых периодов. Реже встречались квадратные и крестообразные ямы. Последняя форма распространена только среди дромосных погребений конца V-IV вв. до н.э.

4) Ориентировка могильных ям тесно связана, с существовавшими в рассматриваемые периоды, традициями погребального обряда. Могильные ямы второй половины VI-V вв. до н.э. чаще имели широтную ориентировку (40,8\%), а ямы конца V-IV вв. до н.э. - меридиональную (32\%).

5) Все дромосные погребения расположены в центральной части кургана. Но нередко, когда вместо ям с дромосом в центре находятся ямы других типов. Вне зависимости от типа захоронений, центральные ямы обычно сильно разграблены и поэтому иногда с трудом могут быть использованы для социальных реконструкций. Несмотря на то, что центральное поло- 
жение ям является одним из критериев элиты, периферийные захоронения тоже могут быть отнесены к элитным. Это хорошо проиллюстрировано на материалах погребения 2 из кургана 1 могильника Филипповка I, где в южной поле кургана было обнаружено непотревоженное погребение, соответствующее всем критериям элитного захоронения. Стоит отметить, что это погребение хоть и не являлось центральным, но находилось под деревянными плахами общего надмогильного сооружения, что свидетельствует об одновременном его совершении с элитным дромосным погребением в центре. Таким образом, элитным может быть не только погребение, но и весь погребальный комплекс - курган или могильник. Похожей точки зрения придерживался и Л.Т. Яблонский, который считал, что выделенные им признаки элиты являются маркером не только погребенного, но и целого могильника (Яблонскиц̆, 2015. С. 37-61).

6) Размеры и глубина ям - важные социо-информативные признаки в силу учета трудозатрат на их сооружение. Из всех типов погребений наиболее «компактными» оказались ямы с подбоями. Высокой вариативностью отличались простые ямы, среди которых встречались как маленькие и неглубокие, так и большие ямы. К обширным глубоким ямам относилось большое количество погребений с деревянными перекрытиями и дромосом.

7) Преобладал индивидуальный характер захоронений во всех типах погребений. Наибольший «всплеск» коллективных погребений фиксируется в памятниках конца V-IV вв. до н.э., что, скорее всего, связано с широким распространением традиции совершения многоактных захоронений в дромосных могилах.

Очевидно, что не все из рассмотренных признаков отражают социальный статус. Также их нельзя назвать однозначными и «до- 
ступными» для проведения социальных реконструкций. В таких признаках, как форма и ориентировка могильных ям, отражаются, бытовавшие в рассматриваемое время, погребальные традиции, а центральное положение погребений в кургане не всегда является маркером элиты, как и наоборот: периферийные захоронения не всегда относятся к рядовому или бедному населению.

Для получения более достоверных данных о наличии дифференцирующих особенностей у захоронений разных типов, был проанализирован, встречающийся в них, погребальный инвентарь. В результате чего было выявлено, что погребения всех типов конца V-IV вв. содержат в себе наиболее богатый инвентарь: в захоронениях с дромосами, деревянными конструкциями, в катакомбах, подбоях и даже в простых грунтовых ямах встречались вещи из драгоценных металлов и предметы импорта. Но среди всех прочих типов именно могильные ямы с дромосом и деревянными конструкциями содержали инвентарь, отличавшийся наибольшим богатством и престижностью.

Таким образом, среди рассматриваемых типов погребений ранних кочевников Южного Урала второй половины VI-IV вв. до н.э., большинство захоронений в ямах с дромосом и с деревянными конструкциями могут относиться к погребениям кочевой элиты. На это указывают: 1) захоронения, совершенные в курганах с большим объемом насыпей; 2) центральное положение погребений в курганах; 3) значительные трудозатраты на совершение захоронений этого типа; 4) относительно большие размеры и глубина ям; 5) высокая частота встречаемости в них предметов престижа, вещей из драгоценных металлов и импорта.

Уже на протяжении многих лет социальный аспект является важным направлением в изучении типов погребений. Исследователями неоднократно отмечалось, что в ямах с дромосом 
погребены представители кочевой элиты ранних кочевников Южного Урала (Смирнов, 1978. С. 62; Мошкова, Малашев, Мещеряков, 2011. С. 311; Таиров, Гаврилюк, 1988. С. 145; Мьикин, 2011. С. 318-334; Яблонский, 2011. С. 238; Сиротин, 2016. С. 27). Поэтому, данное исследование по большей части является лишь очередным подтверждение данного наблюдения.

Что касается остальных, рассматриваемых в работе типов погребений, то, как уже отмечалось, в катакомбах, подбоях и в простых грунтовых ямах тоже встречались изделия из благородных металлов и предметы престижа, но сравнительно реже. К тому же, у большинства захоронений этих типов редко встречаются сразу несколько маркеров высокого социального статуса.

Так или иначе, при исследовании погребений любого типа, необходимо применять индивидуальный подход к изучению каждого из них, так как социальный статус определяется не сколько типом могильной ямы, сколько наличием и взаимовстречаемостью признаков, отражающих социальную дифференциацию в обществе ранних кочевников Южного Урала.

\section{ЛИТЕРАТУРА}

Бунятян Е.П., 1982. Методика социальной реконструкции по данным рядовых скифских могильников // Теория и методы археологических исследований. Киев: «Наукова Думка». С. 136-184.

Мошкова М.Г., Малашев В.Ю., Мещеряков Д.В., 2011. Дромосные и катакомбные погребения Южного Приуралья в савроматское и раннесарматское время // Погребальный обряд ранних кочевников Евразии. Материалы и исследования по археологии юга России / Ред. Л.Т. Яблонский, С.И. Лукъяшко. Ростов-на-Дону: Изд-во ЮНЦ РАН. Вып. ІІІ. С. 302-317. 
Мышкин В.Н., 2011. Погребальная обрядность социальной элиты кочевников Самаро-Уральского региона в VI-V вв. до н.э. (к проблеме формирования прохоровской культуры) // Погребальный обряд ранних кочевников Евразии: Материалы и исследования по археологии юга России / Ред. Л.Т. Яблонский, С.И. Лукъяшко. Ростов н/Д: Изд-во ЮНЦ РАН. Вып. III. С. 318-334.

Сиротин C.B., 2016. Дромосные погребения эпохи ранних кочевников с территории Зауральской Башкирии // Научное периодическое издание «IN SITU». № 11. С. 27-30.

Сиротин C.B., 2015. Дромосные и подбойно-катакомбные погребения ранних кочевников восточной и юго-восточной (степной) Башкирии // Степи Северной Евразии. Материалы VII Международного симпозиума / Под науч. ред. А.А. Чибилева. Оренбург: Печатный дом «Димур». С. 781-783.

Смирнов К.Ф., 1978. Дромосные могилы ранних кочевников Южного Приуралья и вопрос о происхождении сарматских катакомб // Вопросы древней и средневековой археологии Восточной Европы / Отв. ред. В.И. Козенкова, Ю.А. Краснов, И.Г. Розенфельдт. М.: Изд-во Наука. С. 56-64.

Сокровища сарматских вождей (материалы раскопок Филипповских курганов). Оренбург: Димур, 2008. 144 с.

Таиров А.Д., Гаврилюк А.Г., 1988 К вопросу о формировании раннесарматской (прохоровской) культуры // Проблемы археологии Урало-Казахстанских степей / Отв. ред. Г.Б. Зданович. Челябинск: Изд-е Башкирского ун-та. С. 141-159.

Яблонский Л.Т., 2011. Погребальный обряд ранних кочевников Приуралья переходного времени и вопросы археологической периодизации памятников // Погребальный обряд ранних кочевников Евразии. Материалы и исследования по археологии юга России / Ред. Л.Т. Яблонский, С.И. Лукъяшко. Ростов-на-Дону: Изд-во ЮНЦ РАН. Вып. III. С. 235-240. 
Яблонский Л.Т., 2015. Элитарная субкультура ранних кочевников Южного Приуралья и механизмы формирования раннесарматской культуры // Элита в истории древних и средневековых народов Евразии. Барнаул / Отв. ред. П.К. Дашковский. Барнаул: Изд-во Алт. ун-та. С. 37-61.

Tainter J.R., 1978. Mortuary practices and the study of prehistoric social systems // Archaeological Method and Theory. No. 1. P. 105-141.

\section{СВЕДЕНИЯ ОБ АВТОРЕ.}

Гильмитдинова Алина Харисовна, Институт археологии РАН, Москва, Россия, e-mail: $\underline{\text { melnichuk.alina@mail.ru }}$ 


\section{В.И. Завьялов, Н.Н. Терехова \\ Кузнечные артефакты \\ из памятников Скифии и Сарматии (сравнительный технологический анализ)*}

Резюме. Образ жизни и менталитет кочевников не способствовали становлению в местной среде сложных производств. На примере скифских и сарматских кочевых племён даётся технологическая характеристика ремесленной продукции, поступавшей к номадам. В результате археометаллографического анализа установлено, что племена Скифии и Сарматии обеспечивались кузнечной продукцией из разных центров. Эти центры находились на разных уровнях развития производства. Это можно рассматривать как отражение различий в социальном развитии двух групп кочевников.

Ключевые слова: скифы, сарматы, кузнечные изделия, археометаллография, производственный центр.

\section{V.I. Zavyalov, N.N. Terekhova}

\section{Blacksmith artifacts from the monuments of Scythia and Sarmatia (comparative technological analysis).}

Abstract. The lifestyle and mentality of the nomads did not contribute to the formation of complex industries in the local environment. On the example of the Scythian and Sarmatian nomadic

* Статья подготовлена в рамках выполнения Государственного задания Минобрнауки РФ, проект № АААА-А18-118011790092-5 «Археологические и антропологчческие источники и верификация гипотез: методические аспекты фундаментального знания и полевых исследований». 
tribes, a technological characteristic of handicraft products that came to the nomads is given. As a result of archaeometallographic analysis, it was established that the tribes of Scythia and Sarmatia were provided with blacksmith products from different centers. These centers were at different levels of production development. This can be seen as a reflection of the differences in social development of the two groups of nomads.

Key words: Scythians, Sarmatians, blacksmiths, archeometallography, production center.

В истории номадов одной из актуальных является проблема обеспечения их ремесленной продукцией, в частности такого производства, как чёрная металлургия и металлообработка. Возможность решения этой проблемы появилась с внедрением в археологию методов археометаллографии, которые позволяют реконструировать технологию производства кузнечных артефактов. Менталитет кочевников, их образ жизни не способствовали становлению в местной среде подобных сложных производств, которые требовали стационарных условий работы (длительные временные затраты на получение сырья и топлива, сложные пиротехнические сооружения, набор инструментов, специальных приспособлений и т.д.), что в свою очередь предполагает переход к оседлости. При кочевом образе жизни приходилось довольствоваться нестабильными способами получения ремесленной продукции у оседлого населения (либо за счёт торговли или обмена, либо за счёт прямого грабежа, либо за счёт дани).

На примере скифских и сарматских кочевых племён мы имеем возможность дать технологическую характеристику ремесленной продукции номадов, находящихся на разных ступенях социального развития. С этой точки зрения обратимся 
к сопоставимым по времени исследованным нами материалам из Каменского городища, Прохоровских курганов и коллекции случайных находок с территории Башкирии. Кроме того, мы привлекаем опубликованные разными исследователями результаты отдельных анализов, обработанные по применяемой нами методике (Завьялов, Терехова, 2013. С. 32-34).

Наиболее ярким центром Степной Скифии конца V-III вв. до н.э. является Каменское городище, расположенное у г. Каменка-Днепровская (Украина) на левом берегу Днепра. Многолетние археологические исследования этого памятника, начиная с Б.Н. Гракова (30-50 гг. ХХ в.), и вплоть до настоящего времени (раскопки Н.А. Гаврилюк) дали значительный и разнообразный материал, характеризующий получение и обработку чёрного металла. В своё время Б.Н. Граков пришёл к выводу о том, что «Каменское городище явно было постоянным поселением оседлых мастеров-металлургов в этой стране скифов-кочевников» (Граков, 1954. С. 123).

Сарматы же в это время (IV-II вв. до н.э.) продолжают оставаться в рамках кочевого образа жизни, основу хозяйства которого составляло скотоводство.

Кузнечные артефакты из памятников Скифии и Сарматии давно привлекают внимание исследователей истории чёрной металлургии и металлообработки. В частности, уже в 60-е гг. ХХ в. к этим материалам обращался Б.А. Шрамко с группой металловедов (Шрамко и др., 1963; 1970; 1971; 1974). Анализы изделий из скифских и сарматских памятников опубликованы в работах Г.А. Вознесенской, Л.С. Розановой, Н.Н. Тереховой, В.Д. Гопака, Д.П. Недопако, А.Н. Порох, В.И. Завьялова, С.В. Рязанова (Вознесенская, Недопако, 1978; Вознесенская, Розанова, 1989; Вознесенская, Хомутова, 1979; Гопак, Радзиевская, 1990; Завьялов, 2010; Недопако, 2005; Розанова, Терехова, 1988; Терехова, 2011; Рязанов, 2006; Порох, 1999).

Прежде чем перейти к изложению конкретных результа- 
тов сравнительного технологического анализа материалов из скифских и сарматских памятников, необходимо дать некоторые пояснения. В настоящее время мы располагаем достаточно большим количеством свидетельств о том, что уже в раннем железном веке при обработке чёрного металла применялись как простые, так и сложные технологии (Завьялов, Терехова, 2019а). К простым технологиям (технологическая группа I) относятся ковка предметов непосредственно из сырья, полученного в ходе металлургического процесса (железо и сырцовая сталь), без каких-либо дополнительных операций по улучшению механических свойств. Высокотехнологичными (технологическая группа II) для раннего железного века считаются такие приёмы как цементация (искусственное получение стали) готовых изделий или заготовок, различные виды термической обработки. Соотношение простых и сложных технологий в материалах конкретного памятника или археологической культуры позволяет говорить об уровне развития производства.

В настоящее время наиболее представительной является археометаллографически исследованная коллекция из памятников Степной Скифии конца V-III вв. до н.э. (Каменское городище - 80 анализов) (Завьялов, Терехова, 2017). Сарматские изделия IV-II вв. до н.э. (прохоровская культура) представлены 40 анализами (Завьялов, Терехова, 2019б).

Совокупность археометаллографических данных по материалам из Каменского городища позволяет говорить о существовании здесь высокоразвитой техники обработки чёрных металлов. Это иллюстрирует соотношение двух технологических групп - доля группы II (высокие технологии) составляет более 40\%. При этом характерной технологической особенностью кузнечной продукции является высокий процент термообработанных изделий (мягкая закалка и нормализация) - более 50\% артефактов группы II. 
По нашим данным, высокие технологии, представленные среди материалов Каменского городища, хорошо увязываются с кавказскими производственными традициями (Завьялов, Тереховa, 2018). Особенно показательно в этом плане использование таких приёмов термической обработки, как мягкая закалка и нормализация. С технологической точки зрения есть все основания рассматривать Каменское городище как крупный железообрабатывающий центр, производящий высококачественную продукцию.

Накопленные в настоящее время археометаллографические данные, характеризующие технологию железообработки у северокавказских племён позволяют говорить о высоком уровне развития здесь этого производства не позднее VIII в. до н.э. (Вознесенская, 1975; Терехова, 2015). В частности, об этом свидетельствуют широкое развитие приёмов искусственного получения стали и разнообразных видов термической обработки. Особенного внимание заслуживает использование такого приёма как нормализация, который характерен именно для кавказской железообработки. Целью этого приёма является необходимость избежать хрупкости термообрабатывемого изделия. Присутствие предметов, обработанных подобным образом, можно рассматривать как прямое указание на связь с кавказскими центрами железообработки. Есть все основания полагать, что кузнечные изделия Каменского городища выполнены в кавказских производственных традициях.

Иная картина наблюдается при анализе кузнечных изделий из синхронных памятников сарматского круга. Технологическая группа I составляет здесь более $90 \%$ всех исследованных предметов. То есть, при обработке чёрного металла использовались простейшие технологические приёмы: ковка предмета либо целиком из железа или сырцовой стали, либо многослойная сварка заготовки. Последний приём является наиболее характерной чертой сарматского металла этого времени (его доля 
составляет более 20\%). Отметим и практически отсутствие термообработанных изделий (2 экз. из 40 исследованных).

Таким образом, разница в технологии изготовления скифских и сарматских кузнечных изделий очевидна (рис. 1). Естественно, может возникнуть вопрос, не связано ли это с различием в категориальном составе исследованных коллекций. Дело в том, что материалы Каменского городища представлены в основном орудиями труда. В то время как коллекция сарматских изделий состоит из предметов вооружения (мечи и кинжалы).

Однако ещё Б.А. Колчин заметил, что «оружейное производство с глубокой древности всегда находилось на передовом рубеже наиболее высоких технических и научных достижений» (Колчин, 1978. С. 188). Исходя из этого, следует заключить, что, если даже такая престижная категория как предметы вооружения изготовлены с использованием простых технологий, то речь может идти о низком уровне развития производственной культуры источника поступления кузнечных изделий в целом. Таким образом, несмотря на различие категориального состава, сравнительный анализ технологических характеристик кузнечной продукции из памятников Скифии и Сарматии вполне правомерен.

Итак, сопоставляя технологические характеристики кузнечных артефактов из синхронных памятников Скифии и Сарматии, мы имеем возможность говорить о различном уровне развития производственных центров, обеспечивавших номадов кузнечной продукцией. Это можно рассматривать как отражение различий в социальном развитии двух групп кочевников. Так, установлено, что в степной Скифии на рубеже V-IV вв. до н.э. происходят кардинальные изменения, которые были связаны со сменой основ хозяйственной деятельности - освоением земледелия и, как следствие, переходом к оседлому образу жизни (Гаврилюк, 1989. С. 94; Граков, 1954. С. 123). Результатом этого процесса является 
появление высокоразвитых ремесленных центров на территории степной Скифии, служивших стабильным источником кузнечной продукции скифского населения. В противоположность этому сарматам приходилось довольствоваться, по крайней мере, в раннесарматское время, продукцией центра, производившего технологически несложную продукцию. К сожалению, в настоящее время из-за недостатка аналитических данных не представляется возможным наметить локализацию этого центра.

\section{ЛИТЕРАТУРА}

Вознесенская Г.А., Недопако Д.П., 1978. Технология производства металлических изделий Трахтемировского городища // Использование методов естественных наук в археологии. Киев: Наукова думка. С. 21-27.

Вознесенская Г.А., Розанова Л.С., 1989. Технологическое исследование железных предметов с городища Переверзево I // Естественнонаучные методы в археологии / Отв. ред. Е.Н. Черных. М.: Наука. С. 139-146.

Вознесенская Г.А., Хомутова Л.С., 1979. Техника и технология кузнечного производства на городище Марица // СА. № 4. С. 180-188.

Гаврилюк Н.А., 1989. Домашнее производство и быт степных скифов. Киев: Наукова думка. 112 с.

Гопак В. Д., Радзиевская В. Е., 1990. Кузнечное ремесло Коломакского городища в VI-III вв. до н.э. // СА. № 1. С. 199-212.

Граков Б.Н., 1954. Каменское городище на Днепре. (МИА № 36). М.: Академия наук СССР. 240 с.

Завьялов В.И., 2010. Археометаллографическое исследование сарматских железных изделий // Л.Т. Яблонский. Прохоровка. У истоков Сарматской археологии. Материалы и исследования по археологии России. № 12. М.: Таус. С. 298-312. 
Завьядов В.И., Терехова Н.Н., 2013. Кузнечное ремесло Великого княжества Рязанского. М.: ИА РАН. 272 с.

Завьялов В.И., Терехова Н.Н, 2017. Становление кузнечного ремесла в степной Скифии (на примере Каменского городища) // КСИА. Вып. 248. С. 317-331.

Завьялов В.И., Терехова Н.Н., 2019а. К проблеме распространения технологических знаний в области железообработки // РА. № 3. С. 19-25.

Завьялов В. И., Терехова Н. Н., 2019б. Технологические трансформации в производстве клинкового оружия сарматов // Stratum plus. № 4. С. 313-320.

Колчин Б.А., 1978. Оружейное дело древней Руси // Проблемы советской археологии / Ред. В.В. Кропоткин, Г.Н. Матюшин, Б.Г. Петерс. М.: Наука. С. 188-196.

Недопако Д.П., 2005. Технологічні дослідження залізних виробів із скіфського Кам'янського городища // Археологічні дослідження в Україні 2003-2004 pp. Запоріжжя: Дике Поле. С. 412-416.

Порох В.Н., 1999. История кузнечного производства у кочевников Нижнего Поволжья скифской эпохи // Археология Волго-Уральского региона в эпоху раннего железного века и средневековья / Отв. ред. А.С. Скрипкин. Волгоград: Волгоградский государственный университет. С. 300-342.

Розанова Л.С., Терехова Н.Н., 1988. Технологическая характеристика железных изделий из памятников Курского Посеймья // КСИА. Вып. 194. С. 30-36.

Рязанов С.В., 2006. Кузнечная техника савромато-сарматского клинкового оружия из Башкортостана // Южный Урал и сопредельные территории в скифо-сарматское время / Отв. ред. Г.Т. Обыденнова, Н.С. Савельев. Уфа: Гилем, 2006. С. 137-140.

Терехова Н.Н., 2011. Технология производства мечей и кинжалов Южного Приуралья скифского и сарматского времени // 
Европейская Сарматия / Отв. ред. Д.А. Мачинский. СПб: Нестор-История. С. 67-92.

Терехова Н.Н., Завъялов В.И., 2018. Кавказские технологические традиции в производстве железного инвентаря из памятников Степной Скифии // Кавказ в системе культурных связей Евразии в древности и средневековье. ХXX «Крупновские чтения». Материалы международной научной конференции. Карачаевск, 22-29 апреля 2018 г. / Отв. ред. У.Ю. Качкаров. Карачаевск: Из-во КЧГУ им. У.Д. Алиева. С. 266-268.

Шрамко Б. А., Солнцев Л. А., Фомин Л. Д., 1963. Техника обработки железа в лесостепной и степной Скифии // СА. № 4. С. 36-57.

Шрамко Б.А., Фомін Л.Д., Солнщев Л.С., 1970. Техніка виготовлення скіфської наступальної зброї із заліза й сталі // Археологія. XXIII. С. 42-48.

Шрамко Б. А., Фомин Л. Д., Солнцев Л. А., 1971. Новые исследования техники обработки железа в Скифии // СА. № 4. С. 140-153.

Шрамко Б.А., Солнцев Л.А., 1974. Степанская Р.Б., Фомин Л.Д. К вопросу о технике изготовления сарматских мечей и кинжалов // СА. № 1. С. 181-190.

\section{СВЕДЕНИЯ ОБ АВТОРАХ.}

Завьялов Владимир Игоревич, доктор исторических наук, Институт археологии РАН, Москва, Россия, e-mail: v_zavyalov@ $\underline{\text { list.ru }}$

Терехова Наталия Николаевна, кандидат исторических наук, Институт археологии РАН, Москва, Россия. 


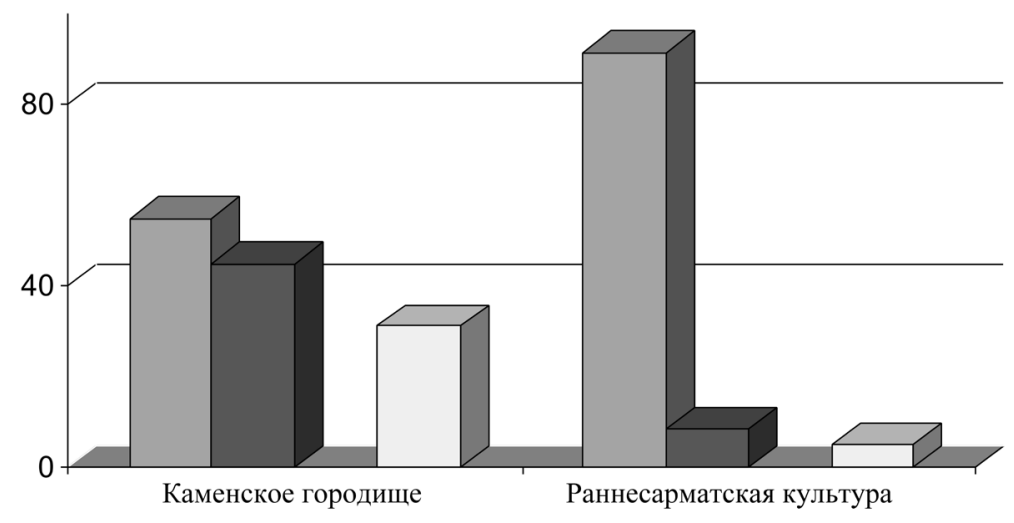

$\square$ Технологическая группа I $\square$ Технологическая группа II $\square$ Термообработка

Рис. 1. Соотношение технологических групп изготовления железных изделий в Степной Скифии (Каменское городище) и в раннесарматской культуре. 


\section{A.P. Канторович, В.Е. Маслов \\ Стелы могильника Новозаведенное-III*}

Резюме. В статье рассмотрены находки неантропоморфных стел из курганного могильника конца V-IV вв. до н. э. в Центральном Предкавказье - Новозаведенное-III. Установка стел на вершине курганов, вероятно, являются продолжением культовой традиции зафиксированной здесь в скифских памятниках второй половины VII - начала VI вв. до н. э. Эта традиция, не имеет местных истоков, и, возможно, связана с сакским миром, где она восходит к культовой практике эпохи поздней бронзы.

Ключевые слова: стелы; менгиры; скифская культура Центрального Предкавказья; курганы

\section{A.R. Kantorovich, V.E. Maslov Steles from the burial ground Novozavedennoye-III}

Abstract. Thearticledealswith thefindsofnon-anthropomorphic steles from a burial mound of the late 5th - 4th centuries BC in the Central Ciscaucasia - Novozavedennoye-III. The installation of steles on the top of the mounds is probably a continuation of the cult tradition recorded here in the Scythian monuments of the second half of the 7 th - early 6 th centuries BC. This tradition has no local origins, and is possibly associated with the Saka world, where it dates back to the cult practice of the Late Bronze Age.

\footnotetext{
* Статья написана в рамках научного проекта РФФИ № 18-09-00725 «Скифы в Центральном Предкавказье в VII-IV вв. до н.э.».
} 
Key words: steles; menhirs; Scythian culture of the Central Ciscaucasia; mounds.

В 2015-2019 гг. на территории Георгиевского городского округа Ставропольского края Ставропольской экспедицией кафедры археологии Исторического факультета МГУ им. М.В. Ломоносова проводились раскопки скифского курганного могильника Новозаведенное-III. Данные работы стали продолжением многолетних исследований памятников скифской культуры сосредоточенных в окрестностях с. Новозаведенное. Здесь под руководством В.Г. Петренко в 1985-2003 гг. был исследован элитарный могильник эпохи скифской архаики Новозаведенное-II, дату которого можно предварительно обозначить как середина третья четверть VII - первая - вторая четверть VI вв. до н. э. Оба памятника располагались почти параллельно, местами в пределах прямой видимости: расстояние между неровными цепочками насыпей, вытянутых в направлении юго-восток - северо-запад не превышала 2,5-3 км.

Исследованиями была затронута, в основном, юго-восточная часть нового памятника, расположенная на высокой надпойменной террасе р. Кумы. Раскопанные курганы №o 1-9 можно разделить на две группы: насыпи высотой свыше 2 м - №№ 1-4, 8 и насыпи, высота которых первоначально не превышала 1,5 м - №o 5, 7, 9. При том, что часть насыпей первой группы была полностью снесена в советский период, об их высоте может свидетельствовать глубина окружавших их рвов, откуда извлекался грунт для строительства курга-

* Исследования выполнялись при поддержке грантов РГНФ № 15-01-18083е и 16-01-18092е, РФФИ № 17-01-18087. Руководитель проектов и начальник экспедииии - зав. кафедрой археологии Исторического факультета МГУ д.и.н. А.Р. Канторович. 
нов. Для курганов первой группы глубина рвов составляет в среднем около 3 м, для второй - 0,5-0,7 м. Существует также определенная корреляция между размерами и глубиной могильных камер в насыпях двух групп: в первой группе площадь могильных камер больше, и они глубже. Таким образом, нельзя исключать, что между погребениями в курганах разных групп имелись некие ранговые социальные различия, которые нельзя проследить по погребальному инвентарю изза древнего разграбления.

По полученным материалам хронологические рамки могильника Новозаведенное-III на сегодняшний день - последняя треть V-IV в. до н.э. (Канторович, Маслов, 2017. С. 116-131, 133; Канторович, Маслов, 2018. С. 196).

В ходе раскопок курганов №№ 2, 6-9 были найдены стелы из необработанного или слабо обработанного камня. Рассмотрим подробнее эти находки.

Курган № 2. Стела из серого песчаника, разломанная на два фрагмента, была обнаружена в центре кургана в грабительской траншее, прорезавшей надмогильную древесно-камышовую конструкцию, к югу от юго-восточного угла могильной камеры на уровне древней погребенной почвы (Канторович, Маслов, 2017. Рис. 5). Нижний фрагмент стелы находился в вертикальном положении, верхний - лежал на ребре. Близ стелы были найдены разнообразные предметы, выброшенные из могильной камеры при ограблении. Размеры фрагментов: нижняя часть - 110 х 65 х 23 см, верхняя - 115 х 60 х 15 см (рис.1, 1, 1a).

Курган № 6. В ходе исследования насыпи кургана в заполнении перекопа грабительской траншеи были обнаружены два крупных обломка столбообразной стелы (без видимых следов обработки) из зеленовато-серого камня (Канторович, Маслов, 2017. Рис. 6). Обломки лежали параллельно в направлении за- 
пад - восток, близ северного края могильной камеры, на уровне древней погребенной почвы. Размеры крупного фрагмента $145 \mathrm{x}$ 25 х 20 - 28 см, меньшего - 78 х 20 × 24 см (рис.1, 2, 2a).

В этом же кургане в придонном заполнении могильной камеры была обнаружена небольшая каменная стела из серого песчаника, лежавшая в направлении северо-восток - юго-запад (Канторович, Маслов, 2017. Рис. 10). Явных следов обработки на ней нет, но её абрис с небольшим выступом мог символизировать антропоморфный образ. Её размеры 53 х 27 х 12 см (рис.2, 1, 1a).

Курган № 7. Отколотый фрагмент стелы из светло-серого песчаника (?) удлиненно-прямоугольной формы был обнаружен в заполнении могильной камеры близ северо-западной стенки, прорезанной грабительской траншеей. Размеры обломка стелы: $97 \times 20$ × 15 см (рис.1, 3).

Курган № 8. Стела - столбообразная плита из желтого песчаника, с выступом в верхней части, напоминающим голову, лежавшая в направлении север - юг с небольшим отклонением к западу, была обнаружена в ходе исследования насыпи кургана в 14,5 м к западу-юго-западу от $\mathrm{R}_{0}$ на глубине -113-128 см (Канторович, Маслов, 2018. Рис. 1, 2). Как выяснилось в ходе дальнейшей расчистки, стела лежала у подножия насыпи, на краю рва.

Один из краев стелы раскололся: отслоились два крупных латеральных фрагмента. С южной стороны стела завершалась выступом, придающим ей антропоморфные очертания; более широкое основание имеет неправильную угловатую форму. Однако видимых следов обработки камня нет. Общие размеры стелы 118 × 60 × 30 см (рис. 2, 2).

Курган № 9. Два отколотых фрагмента стелы из желто-серого песчаника удлиненно-прямоугольной формы были обнаружены в придонном заполнении могильной камеры близ юго-восточного угла, вплотную к восточной стенке, прорезан- 
ной сверху с востока грабительским лазом. Общие размеры стелы 90 х 35 х 17 см (рис.1, 4*).

За исключением миниатюрной стелы из могильной камеры кургана № 6, первоначальное положение которой остается неясным (она была быть установлена как в камере, так и на перекрытии), во всех остальных случаях стелы, очевидно, первоначально, стояли на вершинах насыпей. Их разрушение и перемещение во всех случаях было связано с моментом ограбления курганов: в курганах №№ 7 и 9 куски разбитых стел сползли вместе с заполнением в еще полупустые могильные камеры, сразу после ограбления. Хотя соответствующего исследования на проводилось, визуально породы камня, из которых были сделаны стелы, различаются. Лишь некоторые из разновидностей песчаника предположительно могли быть добыты в пойме р. Кумы. В ближайшей округе нет выходов камня, и часть стел, вероятно, была изготовлена и привезена из предгорий. В таком случае расстояние для их транспортировки составляло не менее 40 км - до окрестностей г. Минеральные Воды или станицы Лысогорской.

Поскольку стелы были найдены в 5-ти из 9-ти исследованных курганов, относившихся к двум размерным группам, можно предположить, что первоначально стелы стояли на всех насыпях могильника. Очевидно, они зримо подчеркивали принадлежность определенной территории, контролировавшей её, семейно-родовому клану. Высота некоторых стел была не менее 2 м - курганы №№ 2 и 6. То, что стелы не были обнаружены при исследовании ряда курганов могильника, в т.ч. крупнейшей насыпи - кургана № 1, вполне объяснимо. Сброшенные стелы грабители могли использовать вторично как каменное сырье или разбить на мелкие части.

* Обломки двух стел были найдены в 2020 г. в ходе исследования кургана 12. 
Очевидно также, что разрушению стел в ходе разграблении могил придавалось важное значение. Это акт демонстративного уничтожения сакрального пространства кургана, который оберегала стела, сопутствовавший корыстному надругательству над захоронениями социальной элиты.

В нашем случае, вероятно, нельзя рассматривать свержение стел и ограбление курганов, как итог межклановой борьбы в скифском обществе. Именно внутренние усобицы М.Н. Дараган рассматривает в качестве причины переиспользования скифских антропоморфных стел и их обломков на примере Зототобалковского могильника (Дараган, 2016. С. 40, 41. Рис. 6; Daragan, 2016. Р. 120-122. Fig. 8). Однако, судя по всему, в окрестностях с. Новозаведенное ограбление скифских курганов было тотальным: в короткий промежуток времени ограблению подверглись все соседние курганы эпохи скифской архаики, простоявшие к тому времени не менее 300 лет нетронутыми. Об этом свидетельствуют материалы впускного погребения в кургане № 13 могильника Новозаведенное-II, где захоронение было произведено в скифскую могильную камеру, сразу после ограбления через грабительский лаз. Это событие произошло около рубежа IV-III вв. до н.э. (Маслов, 1996) - то есть в период исчезновения Скифского царства. Следует отметить также, что курганы обеих групп были ограблены одним и тем же способом: боковыми ходами под насыпью, до краев могильных камер, где на момент ограбления сохранялось деревянно-камышовое перекрытие.

В большие разграбленные курганные насыпи, которые оставались топографическими ориентирами, много веков, до позднего средневековья, никто более не совершал захоронений, хотя активная жизнедеятельность по соседству продолжалась.

Сравнительные исследования материалов могильников Новозаведенное-II и III позволяют установить, что, несмотря 
на хронологический разрыв, между этими памятниками, существует несомненная преемственность в традициях погребального обряда: от эпохи скифской архаики до второй половины IV в. до н.э. (Канторович, Маслов, 2017; 2018). Установка на вершинах курганов стел - важный аспект обрядовых действий, связанный с сакрализацией образа умершего. Преемственность могильника Новозаведенное-III по отношению к могильнику Новозаведенное-II прослеживается и в этом.

Так, в кургане № 6 Новозаведенное-II в заполнении ограбленной могильной камеры, в её центре, была обнаружена стела из зеленовато-серого камня, визуально близкого к породе камня стелы из кургана № 6 могильника Новозаведенное-III. Стела представляла собой каменный столб с оббитыми гранями размером 202 × 39 х 22 см (Петренко, 1988).

В соседнем кургане № 5 при снятии насыпи в юго-западном секторе кургана, в 10 м от центра, встречались обломки сходного серого камня размером до 30 см. Обломок такого же серого камня был найден и на глубине -183 см в центральной части насыпи (нах. 5). Очевидно, и здесь первоначально была установлена стела (Петренко, 1988).

В насыпи кургана на восточной окраине с. Новозаведенного, получившего обозначение как «курган 1 могильника Новозаведенное-I», в 1,6 м к ЮЮ3 от $\mathrm{R}_{0}$ на глубине -56 см был найден «камень среднего размера» (Кореняко, 2001. С. 52. Рис.2). В местных лессовидных суглинках, из которых была сооружена насыпь, вообще не встречаются камни, так что, в любом случае, это артефакт, хотя полной уверенности в том, что этот камень выполнял роль стелы, нет.

Рассмотрим также находки стел из других могильников эпохи скифской архаики.

\footnotetext{
* Стела была передана в 1987 г. в краеведческий музей г. Георгиевска, где бесследно исчезла.
} 
В таком ключевом памятнике для раннескифской археологии, как курган № 1 Краснознаменского могильника, наряду с фрагментом скульптурной стелы, которая по мнению В.Г. Петренко стояла на вершине кургана, в разном контексте найдено сразу три стелы без изображений на поверхности (2006. С. 105. Табл. 58, 6, 7, 9, 15).

В южном секторе насыпи среди плит каменного панциря была обнаружена антропоморфная плита - стела из серого песчаника с моделированными плечами и головой в виде небольшого выступа. В.Г. Петренко связала её с соседними курганами эпохи бронзы, с которых могли собирать камень, для строительства кургана (2006. С. 20, 123. Табл. 58, 9). Действительно, из ближайшего могильника эпохи бронзы происходит похожая стела ( $A$ дреева, Петренко, 1998. С. 32. Рис.16). Однако, как мы постараемся показать ниже, полной уверенности в этом быть не может.

Вторая стела была найдена при расчистке крепиды. Это антропоморфная плита с головой, четко выделенной подтеской (Петренко, 2006. С. 105. Табл. 3; 58, 7). Её атрибуция достаточно условна, поскольку она, очевидно, использована вторично, и также могла относиться к эпохе бронзы.

Наибольший интерес для нас представляет небольшая 125 х 30-40 см столбообразная стела-менгир из северо-восточной части южной гробницы, находившаяся близ жертвенного костра (?) (Петренко, 2006. С. 27, 28, 105. Табл. 3; 58, 15; 85, 2). Зафиксированная здесь ситуация имеет важную параллель в кургане № 16 могильника Купьеваха в Левобережном Приднепровье, где деревянная антропоморфная стела была горизонтально уложена «лицевой» частью вниз в могильной камере кенотафа (?). Под ней находилось зольное пятно, а у заостренного основания размещалась жертвенная пища - шкура козла (?) и разбитая амфора клазоменского типа (Бойко, 1999. С.41. Рис. 1; 2). В.С. Ольховский 
видел в стеле из Купьевахи продолжение киммерийских традиций, связанных с оленными камнями (Ольховский, 2005. С. 121).

Эти два комплекса дают определенные основания для предположения о том, что и в кургане № 6 могильника Новозаведенное-III малая стела была установлена внутри могильной камеры.

Можно также особо отметить камень весом 8 кг уложенный на живот захороненного мужчины в погребении 1/1984 в поле знаменитого Чертомлыкского кургана (Алексеев и др., 1991. С.68, 69. Рис. 44). Но, очевидно, здесь камень играл роль магического оберега, непосредственно связанного с умершим.

В ходе раскопок раннескифского кургана близ юго-западной окраины г. Новопавловск, насыпь которого была покрыта галечным панцирем, в завале над могильной камерой был найден вытянутый гранитный (?) галечный камень, высотой 73 см и диаметром 20-30 см, который, очевидно был установлен на вершине кургана (Канторович и др., 2007. С. 176. Рис. 8).

Серия из трех туфовых стел происходит из курганов №№ 16, 17 и 20 Нартанского могильника, относящихся к числу наиболее ранних насыпей могильника. Все нартанские стелы были найдены в центре курганов (курган № 16) или в центре заполнения могильных камер, вместе с просевшими в них камнями каменных панцирей (курганы №№ 17 и 20) (Чеченов, 1984. С. 219, 220. Рис. 39, 7, 8; 42, 3, 4; Батчаев, 1985. С. 40. Табл. 47).

В кургане № 16 стела представляла собой столб со скругленными гранями и намеченной подтеской головным выступом (Батчаев, 1985. Табл. 41, 31).

В кургане № 17 стела имела неантропоморфную удлиненно-овальную форму с сетчатым декором из бороздок в области невыделенной головы (Батчаев, 1985. Табл. 43, 1).

Стела из кургана № 20 осталось неопубликованной: указано лишь, что это «камень длиной 1,05 м» (Батчаев, 1985. С. 40). 
Существуют различные точки зрения на нартанские стелы. И.М. Чеченов отнес их к эпохе ранней - средней бронзы. Так, стелу из кургана № 17 он сопоставлял с одной из стел Нальчикской гробницы (Чеченов, 1984. С. 247; 1973. С. 15. Рис.16, 5). B.С. Ольховский высказывался в пользу их связи с погребениями раннескифского времени, а декор на стеле из кургана № 17 сопоставлял с декором на глиняной статуэтке из Двина (Ольховский, 2005. С.122, 123. Ил. 97, 2). При этом нартанские стелы исследователь рассматривал как важный образец перехода от неантропомофного изобразительного канона к скифскому антропоморфному, как один из вариантов внешнего инокультурного воздействия на этапе формирования скифских антропоморфных изображений.

Открытие поздней серии стел из могильника Новозаведенное-III противоречит эволюционной версии. В Предкавказье стелы-менгиры сосуществуют с антропоморфной скульптурой, более того, архаичная традиция сохраняется до исчезновения скифской культуры. Предполагаемая связь с оленными камнями на раннем этапе также не выглядит убедительной. Проблема усугубляется сходством отдельных стел скифского периода со стелами эпохи ранней и средней бронзы, отмеченной ещё И.М. Чеченовым (Чеченов, 1984. Рис. 39, 1, 6; 40, 1; 41, 8; 42, 3). Хотя в отдельных случаях стелы эпохи бронзы могли быть использованы по назначению вторично, никакой преемственности в традициях погребального обряда, определенно, не было.

Для предскифских кобанских памятников стелы не характерны. Обломок нижней части стелы был использован при строительстве каменной гробницы 3 могильника Терезе. В.И. Козенкова сочла его вторично использованным фрагментом оленного камня (Козенкова, 2004. С. 137. Рис. 63; 95). Однако так ли это - не ясно, следов изображений на нём нет. Пока достоверно не из- 
вестно, на каких памятниках в Центральном Предкавказье устанавливались немногочисленные известные оленные камни.

Важен факт появления в Центральном Предкавказье стел-менгиров на фоне кратковременного строительства каменных подкурганных сооружений в Краснознаменском могильнике. В.Г. Петренко связала появление каменной архитектуры с прибытием новой волны кочевников из Азии (Петренко, 2006. С.120). Параллели для каменных сооружений краснознаменских курганов исследователь видит, прежде всего, в памятниках бегазы-дандыбаевской культуры, хотя допускает участие в строительстве и переднеазиатских мастеров (Петренко, 2006. С. 52). Для этой культуры характерны стелы-менгиры (Бейсенов и др., 2014. С. 27, 28).

Но очевидные, более близкие параллели центральной дромосной гробнице царского Краснознаменского кургана 1 имеются среди сакских памятников Центрального и Восточного Казахстана (Бейсенов., 2015. С. 26, 28. Рис.11). В последние годы на территории Казахстана открыта большая серия различных образцов каменных изваяний: оленные камни, стелы-менгиры, разнотипные статуарные антропоморфные изображения, некоторые из которых обнаруживают несомненную близость к скифским изваяниям (Гуцалов, Таиров, 2000. Рис. 8, 1, 4; Бейсенов, 2015. С. 35. Рис. 18, 1).

Стелы-менгиры непосредственно связаны с сакской каменной курганной архитектурой (Бейсенов, 2015. С. 12, 35; Бейсенов и др., 2015. С. 62, 64). Поэтому, не исключено, что традиция использования стел-менгиров, зачастую лишенных антропоморфных черт, появляется, как многие другие элементы раннескифской культуры с востока - из сакского мира. Следует подчеркнуть необычайно консервативных характер скифской культуры в Центральном Предкавказье, наряду со стелами из раннего этапа раннескифской культуры в поздний переходят такие культовые предметы как наборы галек и плиты- тёрочники, 
исследование которых должно стать предметом самостоятельной работы (Канторович, Маслов, 2018. С. 197). Возможно, такой культурный консерватизм был обусловлен существованием во враждебном, подвластном окружении. Скифская элита широко пользовалась предметами, характерными для кобанской культуры, но отвергала местные культурные стереотипы. Своеобразным визуальным идеологическим стержнем при этом оставался скифский «звериный стиль», сохранявший связь с другими регионами скифского мира (Канторович, 2018).

\section{ЛИТЕРАТУРА}

Алексеев А.Ю., Мурзин В.Ю., Ролле Р., 1991. Чертомлык (Скифский царский курган IV в. до н. э.). Киев: Наукова думка. 416 с.

Андреева М.В., Петренко В.Г., 1998. Комплексы эпохи бронзы из кургана у хутора «Красное знамя» // МИИКНСК. Вып.1. / Отв. ред. А.Б. Белинский. Ставрополь. С. 7-54.

Батчаев B.M., 1985. Древности предскифского и скифского времени // Археологические исследования на новостройках Кабардино-Балкарии в 1972-1979 гг. Т. 2: Памятники эпохи бронзы и раннего железа / Отв. ред. М.П. Абрамова, В.И. Козенкова. Нальчик: Эльбрус. С. 7-115.

Бейсенов А.3., 2015. Поселения и могильники сакской эпохи Центрального Казахстана // Сакская культура Сарыарки в контексте изучения этносоциокультурных процессов Степной Евразии. Сборник научных статей, посвященный памяти археолога К.А. Акишева / Отв. ред. А.З. Бейсенов. Алматы: НИЦИА «Бегазы-Тасмола». С. 59-70.

Бейсенов А. 3., Варфоломеев В. В., Касеналин А. Е., 2014. Памятники бегазы-дандыбаевской культуры Центрального Казахстана / Отв. ред. В.В. Евдокимов. Алматы: ИА им. А.Х. Маргулана. 192 с.; илл. 
Бейсенов А.З., Джумабекова Г.С., Базарбаева Г.А., Баринова Е., Крешиоли Л., 2015. Археологические исследования могильника раннего железного века Каспан 6 в Жетысу // Сакская культура Сарыарки в контексте изучения этносоциокультурных процессов Степной Евразии. Сборник научных статей, посвященный памяти археолога К.А. Акишева / Отв. ред. А.З. Бейсенов. Алматы: НИЦИА «Бегазы-Тасмола». С. 59-70.

Бойко Ю.П., 1999. Погребение скифского времени с деревянной стелой // Проблемы скифо-сарматской археологии Северного Причерноморья (К 100-летию Б.Н. Гракова) / Отв. ред. П.П. Толочко. Запорожье: ЗГУ. С. 41-45.

Гуиалов С.Ю., Таиров А.Д., 2000. Стелы и антропоморфные изваяния раннего железного века южно-уральских степей // Археология, палеоэкология и палеодемография Евразии / Отв. ред. В.С. Ольховский. М.: ГЕОСС. 226-251.

Дараган М.Н., 2016. Скифские междоусобицы // ВДИ. 2016. 1 (76). C. 22-62.

Канторович А.Р., 2018. Изделия в скифском зверином стиле из курганного могильника Новозаведенное-ІІІ в Центральном Предкавказье // На ионийский лад я пою...: сборник статей в честь Н.М. Никулиной / Под ред. Т.П. Кишбали, М.А. Лопухова, Н.А. Налимова, И.И. Тучков / Труды исторического факультета МГУ. Т. 139. Москва: КДУ; Университетская книга. С. 142-170.

Канторович А.Р., Маслов В.Е., 2017. Могильник Новозаведенное-III как свидетельство пребывания скифов в Центральном Предкавказье в конце V-IV в. до н. э. // Исторические исследования. Вып.8. С. 107-139.

Канторович А.Р., Маслов В.Е., 2018. Скифский курганный могильник Новозаведенное-III в Центральном Предкавказье: три сезона исследований // Кавказ в системе культурных связей Евразии в древности и средневековье. XXX «Крупновские чте- 
ния». Материалы международной научной конференции. Карачаевск, 22-29 апреля 2018 г. / Отв. Ред. У.Ю. Кочкаров. Карачаевск: Из-во КЧГУ им. У.Д. Алиева. С. 196-198.

Канторович А.Р., Петренко В.Г., Маслов В.Е., 2007. Раскопки кургана раннескифской эпохи у г.Новопавловска (предварительная публикация) // МИИКНСК. Вып.VII. / Гл. ред. А.Б. Белинский. М.: Памятники исторической мысли. С. 168-207.

Козенкова В.И., 2004. Биритуализм в погребальном обряде древних «кобанцев». Могильник Терезе конца XII-VIII вв. до н. э. МИИКНСК. Вып. V. / Гл. ред. А.Б. Белинский. Москва: Памятники исторической мысли. 220 с.; илл.

Кореняко В.А., 2001. Курган раннескифского времени у села Новозаведенное Ставропольского края // Северный Кавказ: историко-археологические очерки и заметки. МИАР № 3 / Отв. ред. М.П. Абрамова, В. И. Марковин. М.: Гриф и К. С. 52-64.

Маслов В.Е., 1996. Впускное погребение из кургана № 13 могильника Новозаведенное-ІІ // ИАА. Вып. 2 / Отв. ред. Р.М. Мунчаев. Армавир. М.: АКМ. С. 66-71.

Ольховский В.С., 2005. Монументальная скульптура населения западной части евразийских степей эпохи раннего железа / Отв. ред. М.Г. Мошкова, Е.А. Попова. М.: Наука. 299 с.

Петренко В.Г., 1988. Отчёт о раскопках курганного могильника Новозаведенное-ІІ Ставропольского края в 1987 г. // Архив ИА РАН. Р-1. №№ 13817, 13918.

Петренко В.Г., 2006. Краснознаменский могильник. Элитные курганы раннескифской эпохи на Северном Кавказе // Corpus tumulorum scythicorum et sarmaticorum. T. III. / Отв. ред. А.И. Иванчик, М.Г. Мошкова. Москва, Берлин, Бордо: Палеограф. 175 с.; илл.

Чеченов И.М., 1973. Нальчикская подкурганная гробница (III тыс. до н. э.) / Отв. ред. В.И. Марковин. Нальчик: Эльбрус. 68 с. 
Чеченов И. М., 1984. Вторые курганные группы у селений Кишпек и Чегем 2 // Археологические открытия на новостройках Кабардино-Балкарии в 1972-1979 гг. Т. 1 / Отв. ред. В. И. Марковин. Нальчик: Эльбрус. С. 164-253.

Daragan Marina N., 2016. Scythian Internecine Feuds // ACSS. 22 (2016) P. 96-140.

\section{СПИСОК СОКРАЩЕНИЙ}

АКМ - Армавирский краеведческий музей

ВДИ - Вестник древней истории. - М.

ЗГУ - Запорожский государственный университет. - Днепропетровск.

ИАА - Историко-археологический альманах

КЧГУ - Карачаево-Черкесский государственный университет

МИАР - Материалы по истории и археологии России

МИИКНСК - Материалы по изучению историко-культурного наследия Северного Кавказа. Москва; Ставрополь.

ACSS - Ancient Civilisations from Scythia to Siberia. Leiden.

\section{СВЕДЕНИЯ ОБ АВТОРАХ.}

Канторович Анатолий Робертович, доктор исторических наук, МГУ им. М.В. Ломоносова, Москва, Россия, е-mail: kantorovich@mail.ru

Маслов Владимир Евгеньевич, кандидат исторических наук, Институт археологии РАН, Москва, Россия, e-mail: maslovlad@mail.ru 


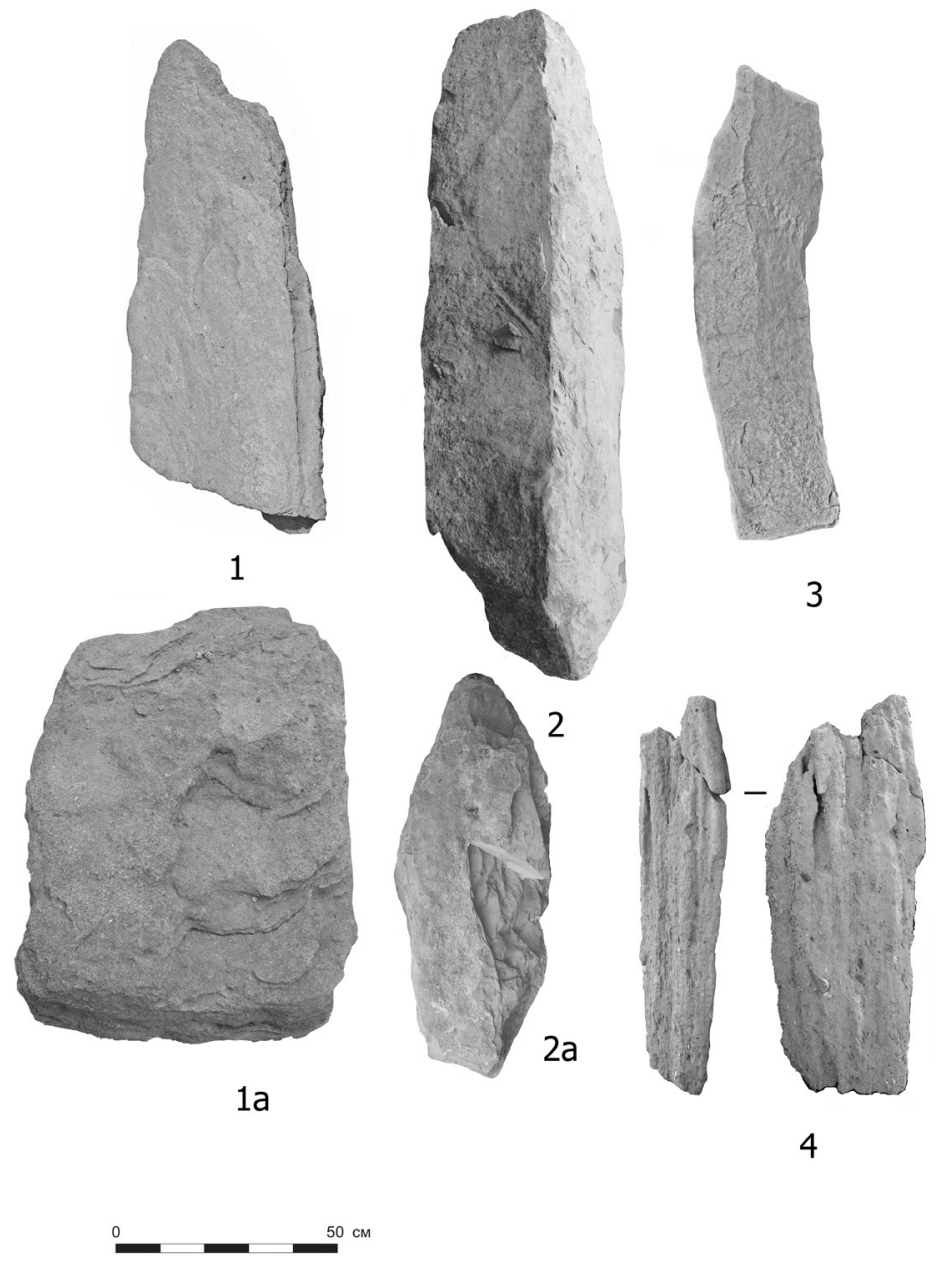

Рис. 1. Могильник Новозаведенное-III. 1-1a - фрагменты стелы из кургана № 2; 2-2a - фрагменты стелы из кургана № 6; 3 - фрагмент стелы из кургана № 7; 4 - фрагменты стелы из кургана № 9. 


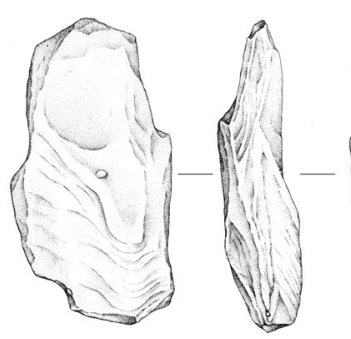

1
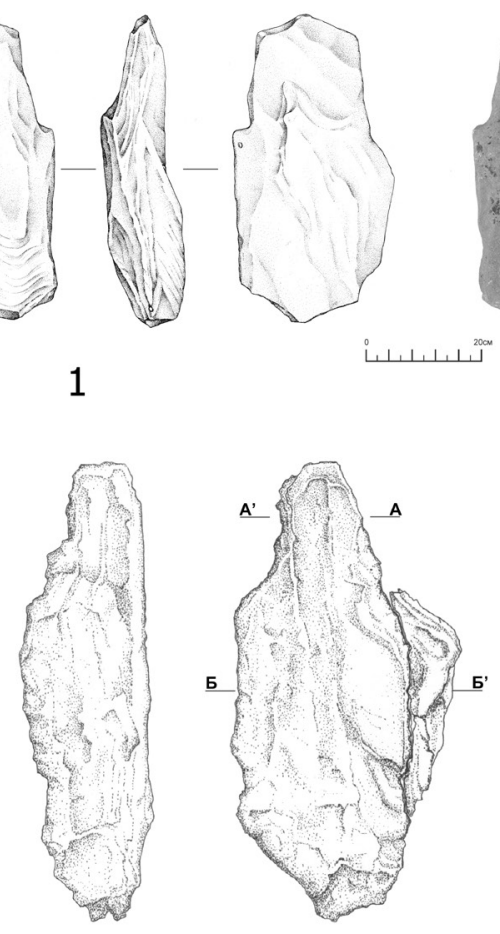

(1)

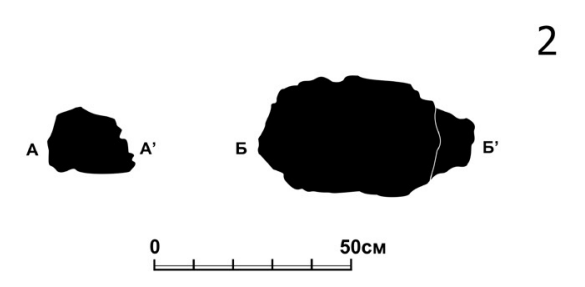

Рис. 2. Могильник Новозаведенное-III. 1-1a - стела из могильной камеры кургана № 6; 2 - стела из кургана № 8. 


\section{В.М. Клепиков}

\section{Нестандартное клинковое оружие из погребений IV в. до н.э. в Нижнем Поволжье}

Резюме. Статья посвящена анализу двух савроматских воинских погребений из раскопок в Астраханской области. Особенностью этих комплексов является наличие длинных мечей без навершия и перекрестия. Такие мечи нехарактерны для савроматского и раннесарматского вооружения, и получают широкое распространение лишь в позднесарматское время. Савроматы, вероятно, в условиях изменившейся военно-политической обстановки и миграционного давления с востока, не имея своей производственной базы, вынуждены были менять традиционный набор вооружения, обращаясь к западным соседям в поисках новых типов оружия. Железные втульчатые наконечники стрел, мечи синдо-меотского типа позволяют предположить ориентацию на Кавказ и Прикубанье. Вероятно, и мечи без навершия и перекрестия были получены из этих регионов.

Ключевые слова: Нижнее Поволжье, погребальный обряд, савроматы, мечи, наконечники стрел, миграции.

\section{M. Klepikov}

\section{Non-standard bladed weapons from burials of the IV century $\mathrm{BC}$ in the Lower Volga region}

Abstract. The main subject of this article is the analysis of the two Sauromatian military burials unearthed in the Astrakhan region. A key characteristic of these complexes is the long swords without pommel and crosshair. Such swords were not typical for Sauromatian 
and Early-Sauromatian weapon and were widely distributed only in the Late-Sauromatian time. Due to the migration pressure from the East and the military-political situation changes, the Sauromats without having their own production base, were probably forced to abandon their traditional set of weapons and reached out to their Western neighbors for new types of armament. The iron socketed arrowheads and the swords of the Sindo-Meotian type allow to suggest the focus on the Caucasus and Kuban. Probably the swords without pommels and crosshairs were received from these regions.

Keywords: Lower Volga region, funeral rites, Sauromats, swords, arrowheads, migration.

Клинковое оружие савроматов во всем его своеобразии хорошо известно исследователям и широко представлено многочисленными публикациями. Господство коротких мечей с разнообразными фигурными перекрестиями и навершиями сменяется к IV веку до н.э. короткими и длинными мечами т.н. «переходных» форм, причем эти изменения явно связаны с восточным, южноуральским регионом, где тогда же появляются железные черешковые наконечники стрел. Мечи этого нового облика начинают появляться и в Нижнем Поволжье, вероятно вместе с носителями такого типа оружия. Мы фиксируем их вместе с появлением в Заволжье курганов-кладбищ и, по обе стороны Волги, диагональных погребений.

Миграционная активность, вероятно, вызвала к жизни и смену набора вооружения, включающего теперь длинный меч, копье и традиционный колчан (Клепиков, 2002. С. 132). Тогда же в степях Поволжья и Приуралья стали появляться мечи синдо-меотского типа, явно фиксирующие усиление контактов с северокавказским населением. 
Однако среди упомянутого разнообразия савроматского клинкового оружия как-то остались незамеченными два меча из погребений IV в. до н.э. в Нижнем Поволжье, хотя в сводках клинкового оружия Нижнего Поволжья они были отмечены (Клепиков, 2007. С. 51-52). Речь пойдет о погребениях из могильников Никольское IV и Старица.

Курганная группа Никольское IV, курган 1 погребение 3 (рис. 1). Курганная насыпь диаметром 20 м, высотой 0,35 м сооружена в эпоху бронзы. Погребение 3 (впускное) обнаружено в северной части кургана на глубине 161 см. Могильная яма подпрямоугольной формы была ориентирована по оси запад-восток. На дне ямы погребенный был уложен вытянуто на спине, головой на запад. Среди сопутствующего инвентаря следует отметить наличие длинного меча (79 см) вдоль левой ноги. Клинок меча без навершия и перекрестия был согнут. Между мечом и бедром, и в ногах обнаружено 8 бронзовых втульчатых наконечников стрел и 10 спекшихся железных, вероятно также втульчатых. На левом крыле таза и на левом колене найдены две костяные ворворки, одна четырехугольной формы, вторая - овальной. Под левым крылом таза найден каменный оселок с отверстием для подвешивания. В ногах также обнаружен железный колчанный крючок. В головах, справа от черепа поставлен глиняный лепной горшок с примесью ракушки в тесте (Дворниченко В. В., Федоров-Давыдов Г.А., 1989. С. 100-104).

Курганный могильник Старица, курган 4 погребение 9 (рис. 2). Курганная насыпь высотой 4,20 м, диаметром до 88 метров, была сооружена в эпоху бронзы. Погребение 9 (впускное) обнаружено в насыпи в юго-западном секторе кургана, на глубине 2,95 м от центрального репера. Границы могильной ямы не прослежены. На дне могилы лежал костяк мужчины на спине, вытянуто, головой на восток с небольшим отклонением к северу. Под костяком и выше левого плеча прослеживались остатки дерева, по-видимому, 
от гробовища. Сопутствующий инвентарь представлен длинным железным мечом без навершия и перекрестия (1 м), лежавшим вдоль левой ноги. Под костями левой руки обнаружен сигаровидный оселок из серой гальки с отверстием для подвешивания. В ногах слева найдено 7 бронзовых втульчатых наконечников стрел и около 140 железных, также втульчатых. Рядом с колчаном находились железный ножичек и две ворворки: одна квадратная костяная, вторая полусферическая золотая. Еще одна золотая ворворка меньшим диаметром найдена на шейных позвонках. Рядом с колчаном в ногах стоял лепной широкогорлый, сероглиняный кувшин с круглой в сечении ручкой и лепной горшочек с выпуклыми боками и отогнутым наружу краем. Поверхность сосуда светло-коричневая с темными пятнами копоти (Шилов, 1960).

Погребения обнаруживают значительное сходство как в традициях погребального обряда, так и в номенклатуре сопутствующего инвентаря. Ориентация погребенного в широтном направлении, набор ворворок, сочетание бронзовых и железных втульчатых наконечников стрел позволяет отнести эти погребения к памятникам савроматского времени. Длинные мечи получают распространение в Нижнем Поволжье с IV в. до н.э., периодически встречаясь как в курганах-кладбищах прохоровской культуры Заволжья, так и в одиночных диагональных погребенияx IV в. до н.э. по обе стороны Волги. Однако длинные мечи этого времени представлены, как правило вариантами так называемого переходного типа, с дуговидными либо согнутыми под тупым углом перекрестиями и аналогичными, либо брусковидными навершиями, что свидетельствует о приуральских источниках их появления (Клепиков, 2007. Рис. 1). В то же время, ворворки, как часть портупейной гарнитуры, широко представленные комплектами начиная со скифского времени, с III в. до н.э. исчезают из употребления, спорадически обнаруживаясь единичными эк- 
земплярами. C III в. до н.э. в Нижнем Поволжье получают распространение и железные черешковые наконечники стрел, хотя железные втульчатые к западу от региона продолжали использоваться вплоть до рубежа эр. Все это позволяет датировать анализируемые погребения второй половиной IV - началом III в. до н.э. Именно в это время начинаются миграции прохоровского населения и занятие им заволжских степей, что отразилось в появлении целой серии могильников с курганами-кладбищами (Лапасина, Лятошинка, Эльтон, Новоузенск). Вероятно, тогда же из Заволжья были вытеснены относительно немногочисленные группы савроматского населения. Однако, на волжском правобережье мигранты появлялись эпизодически, о чем свидетельствует отсутствие здесь родовых могильников, сооруженных в прохоровской традиции. К тому же, савроматское население на этой территории продержалось как минимум до середины III в. до н.э. . Известное савроматское погребение из Кривой Луки VI (курган 1 погребение 14) с гераклейской амфорой может служить тому подтверждением (Дворниченко, Малиновская, Федоров-Давыдов. 1977. С. 67). Активное противостояние аборигенного и пришлого населения, вероятно нашло отражение в разнообразии и явном увеличении вооруженности кочевников.

На этом фоне, появление длинных мечей без навершия и перекрестия выглядит вполне логично, однако требует объяснения источник происхождения. Мечи такого типа хорошо известны в позднесарматское время, что видно и смутило авторов публикации комплекса из Никольского, предположивших позднесарматскую принадлежность погребения (Дворниченко, Федоров-Давыдов, 1989. С. 104). Подобные мечи в I-II вв. н.э. встречаются на Боспоре и в Прикубанье (Горончаровский. 2003. С. 52-57. Рис. 15; Марченко, 1996. С. 56-57), но для IV в. до н.э. это нехарактерно. Определенные аналогии можно найти в материалах раннесармат- 
ского времени Центрального Предкавказья. В опубликованных Ю.А. Прокопенко сводках клинкового оружия второй половины I тыс. до н.э. встречаются немногочисленные мечи без навершия и перекрестия, датированные автором III-I вв. до н.э., однако среди экземпляров V-IV вв. до н.э. таких мечей нет (Прокопенко, Рис. $91,93)$. Относительно длинный (63 см) однолезвийный меч без навершия и перекрестия, найденный на Кубани, датирован И.И. Марченко концом III - первой половиной II в. до н.э. (Марченко, 1996. С. 59. Рис. 97, 6-13). Более точные аналогии отсутствуют, но поскольку наиболее ранние находки длинных мечей без навершия и перекрестия обнаруживаются именно на этой территории, можно предположить, что такие мечи могли появиться из этого региона. Заметим, что на IV в. до н.э. ложится и широкое распространение отсюда мечей так называемого синдо-меотского типа, получивших распространение не только в Прикубанье и на Северном Кавказе, но и на Дону, в Нижнем Поволжье и далее вплоть до Приуралья (Смирнов, 1980. С. 43. Рис. 1, 3).

Однако следует обратить внимание на разницу в клинках. Не только мечи синдо-меотского типа, но и те, что отличаются от них отсутствием навершия, имеют сужающиеся к острию лезвия. В случае с анализируемыми экземплярами мы имеем дело с параллельными лезвиями клинка, более похожими на так называемые «переходные» мечи ранних прохоровцев.

Тем не менее и в погребениях раннесарматской культуры, хотя и на более позднем этапе, можно найти аналогию длинным мечам без навершия и перекрестия из Никольского и Старицы. Летом 2017 года в Северном Казахстане при раскопках кургана 1 могильника Каратомар было обнаружено впускное раннесарматское погребение с хронологически значимым сопутствующим инвентарем, среди которого вместе с ложковидной подвеской, бронзовой ажурной рамчатой пряжкой со сценой терзания 
и железными черешковыми наконечниками стрел обнаружен длинный меч $(94,5$ см) без навершия и перекрестия, положенный в могилу вдоль правой ноги уже в сломанном состоянии. Погребение датируется концом раннесарматской культуры в пределах II-I вв. до н.э. (Логвин, Шевнина, Сеитов, 2019. С. 316-324).

Заметим, что традиция «умерщвления» меча при положении в могилу, известная в раннесарматских и среднесарматских погребениях, зафиксирована и в савроматском комплексе из Никольского, что свидетельствует о длительности существования этого ритуала в среде евразийских кочевников. При этом использование длинных мечей без металлических наверший и перекрестий так же практикуется на всем протяжении сарматской эпохи, хотя широкое распространение такое оружие получит лишь в позднесарматское время. Вероятно, этот достаточно простой в изготовлении тип меча имел накладки на рукоять, возможно, съемное навершие, однако здесь мы можем лишь высказывать определённые предположения, опираясь на более поздние аналогии.

\section{ЛИТЕРАТУРА}

Горончаровский В. А. 2003. Между Империей и варварами: военное дело Боспора римского времени. СПб.: Филоматис. 224 с.

Дворниченко В. В., Малиновская Н. В., Федоров-Давыдов Г. A.. 1977. Раскопки курганов в урочище Кривая Лука в 1973 г. // Древности Астраханского края. М.: Наука. С. 3-77.

Дворниченко В. В., Федоров-Давыдов Г.А., 1989. Раскопки курганов в зоне строительства Калмыцко-Астраханской и Никольской рисовых оросительных систем // Сокровища сарматских вождей и древние города Поволжья. М.: Наука. С. 14-132.

Клепиков B.M., 2007. Раннесарматские мечи в Нижнем Поволжье // Вооружение сарматов: региональная типология и хро- 
нология: доклады к VI м/н конференции / Отв. ред. Л.Т. Яблонский, А.Д. Таиров. Челябинск: ЮУрГУ. 2007. С. 51-57.

Клепиков, В. М., 2002. Сарматы Нижнего Поволжья в IVIII вв. до н. э. Волгоград: ВолГУ. 216 с.

Логвин А.В., Шевнина И.В., Сеитов А.М., 2019. Раннесарматское погребение кургана 1 могильника Каратомар // Маргулановские чтения - 2019: Материалы Международной археологической научно-практической конференции, посвященной 95-летию со дня рождения выдающегося казахстанского археолога К.А. Акишева / Гл. ред. Б.А. Байтанаев. Нур-Султан. С. 316-327.

Марченко И.И., 1996. Сираки Кубани (по материалам курганных погребений Нижней Кубани). Краснодар: КубГУ. 336 с.

Прокопенко Ю.А. 2014. Скифы, сарматы и племена кобанской культуры Центрального Предкавказья во второй половине I тыс. до н.э. Часть 2. Ставрополь: СКФУ. 726 с.

Смирнов К. Ф., 1980. О мечах и кинжалах синдо-меотского типа // КСИА. Вып. 162. С. 38-45.

Шилов В.П., 1960. Отчет о раскопках Астраханской археологической экспедиции в 1960 году // Архив ИА РАН. Р.-1. № 2155.

\section{СВЕДЕНИЯ ОБ АВТОРЕ.}

Клепиков Валерий Михайлович, кандидат исторических наук, Волгоградский государственный университет, Волгоград, Россия, e-mail: valery.klepikov@mail.ru 


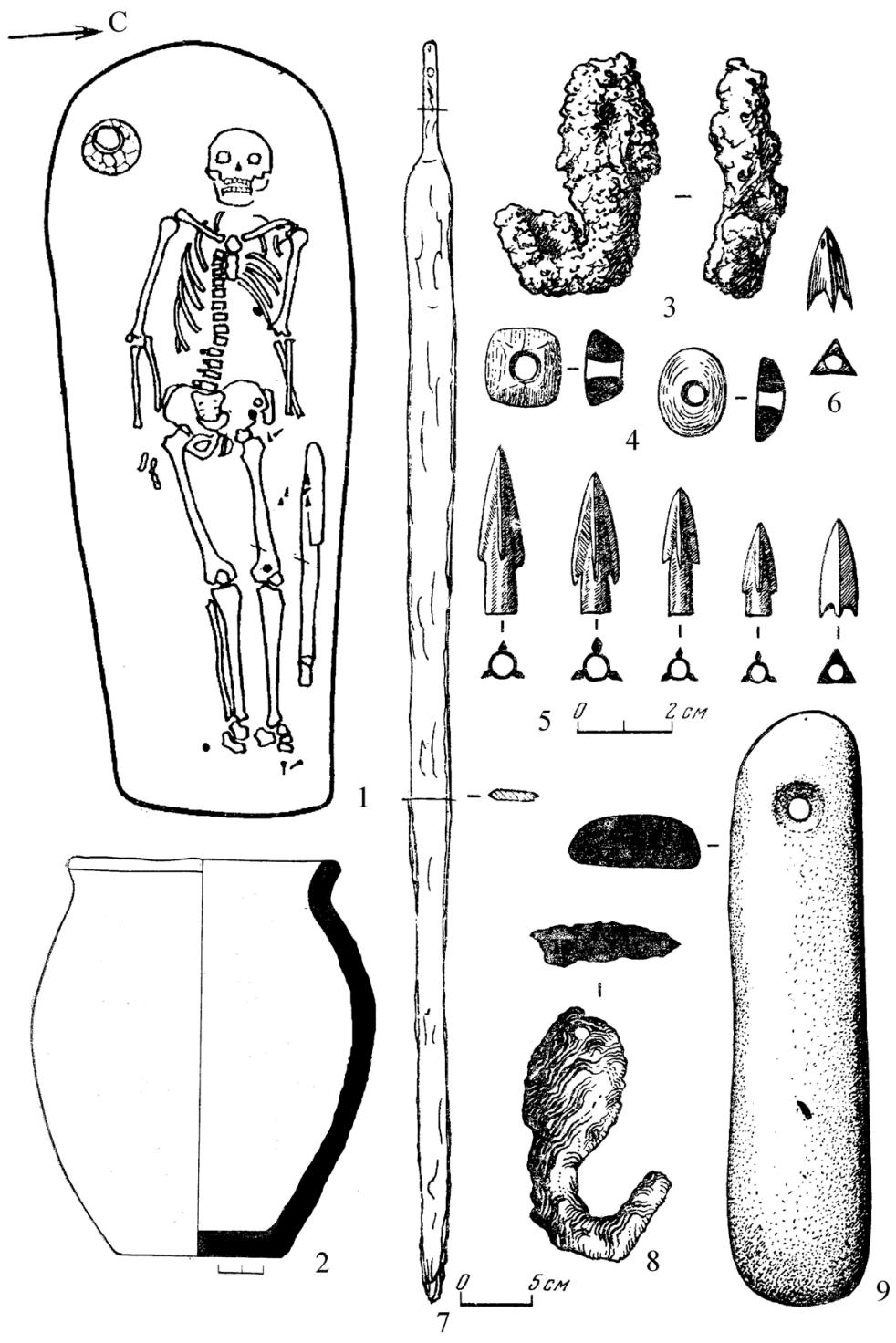

Рис. 1. Могильник Никольское IV. Курган 1, погребение 3. 


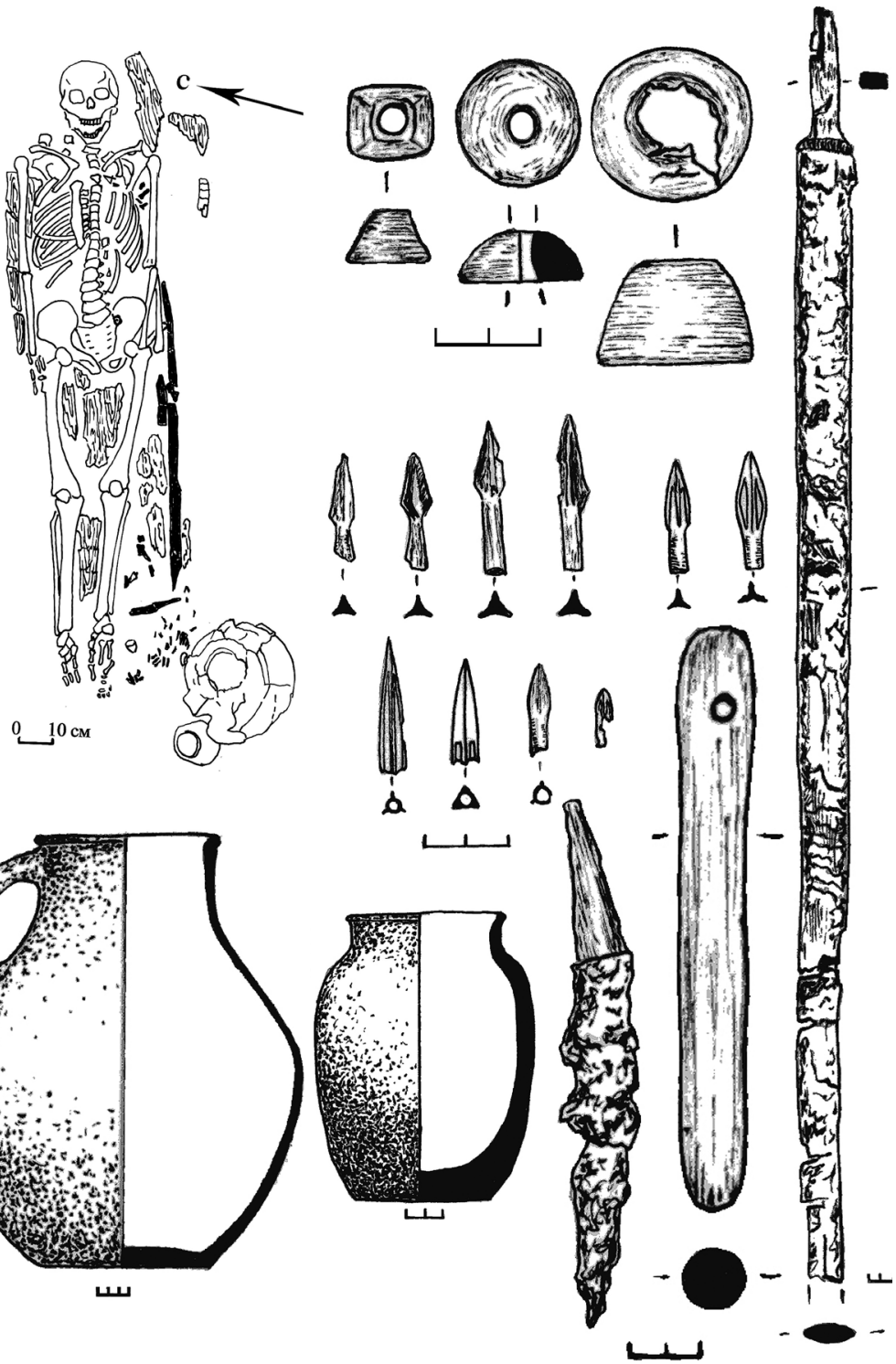

Рис. 2. Могильник Старица. Курган 4, погребение 9. 


\section{Л.А. Краева}

\section{Систематизация и алгоритм описания сарматской керамики *}

Резюме. В статье предлагается систематизация и алгоритм описания сарматской лепной керамики, которые состоят из 6 уровней. Предлагаемая систематизация форм и описания сложилась по ходу изучения технологии более 1500 сосудов из погребальных комплексов Южного Приуралья VI вв. до н.э. - IV в. н.э. (включая Западный Казахстан), но данная система может быть использована и для других территорий.

Ключевые слова: керамика, систематизация, типология, сарматы, ранний железный век

\section{L.A. Kraeva}

\section{Systematization and algorithm for describing Sarmatian ceramics}

Abstract. The article suggests an algorithm for describing Sarmatian stucco ceramics, which results in the systematization consisting of 6 levels. The proposed systematization of forms and descriptions has developed in the course of studying the technology of production of more than 1500 vessels from the burial complexes of the southern Urals (including Western Kazakhstan) of the $4^{\text {th }}$ century $\mathrm{BC}-4^{\text {th }}$ century AD. The suggested system can be used for other territories as well.

* Работа подготовлена при поддержке гранта РФФИ, проект № 18-0940031 . 
Keywords: ceramics, systematization, typology, Sarmatians, early iron age.

В сарматских захоронениях керамическая посуда встречается в значительном количестве и является одним из самых массовых материалов.

Общая периодизация истории изучения савромато-сарматских племен была рассмотрена Мариной Глебовной Мошковой (Мошкова, 1989. С. 158-164).

В связи с тем, что интенсивность изучения керамики на каждом этапе была непоступательной и различной, нами были выделены периоды, согласно росту внимания к сарматской керамике как к историческому источнику в разные годы: I - начало XX века - 1918 г.; II - 1919 - конец 40-х гг.; III - 50-80-е гг.; IV 90-е - начало XXI века (Краева, 2007. С. 257-265).

За многие годы изучения сарматской культуры типология керамической посуды продолжала рассматриваться в общем контексте, наряду с погребальным обрядом и другими категориями вещевого инвентаря.

В последнее время создание обобщающих типологических классификаций приобретает локальный характер, а при описании керамики из разных могильников продолжается терминологическая путаница, которая зародилась еще на первом этапе ее изучения.

Парадоксально, но до сих пор не существует общей классификации сарматской керамики, признанной всеми исследователями. Отсутствует четкость в описании керамики и каждый автор прибегает порой к своим довольно специфическим терминам, акцентируя внимание на каких-то отдельных особенностях керамики, например, соединяя форму и орнаментацию 
(керамика с гофрированным горлом); технологию и категорию (тальковая керамика) или форму и функционал (к курильницам относят горшки, основываясь только на нагаре). Выделение типов керамики производится обычно применительно к керамическому материалу региона или конкретного памятника. Не решена также проблема разделения сосудов по функциональному назначению. Часто перед исследователем стоят вопросы: кувшин это или горшок; курильница или туалетный сосудик.

Несмотря на то, что к изучению сарматской керамики в разные годы обращались неоднократно многие исследователи, специальной монографии, посвященной морфологии и орнаментации сарматской керамики нет.

Исследуя технологию изготовления керамики, невозможно не обращать внимание на морфологию, анализ которой позволяет выделить ряд причин, которые препятствуют созданию общей классификации сарматской керамики (Краева, 2018. С. 140-143). Первыми из которых следует назвать трудоемкость изучения керамики, учитывая массовость этой категории инвентаря, а также отсутствие единого терминологического аппарата не только при описании сарматской керамики, но и при описании керамики в целом.

Основной же трудностью в разработке общей типологии сарматской керамики является наличие большого разнообразия форм сарматских сосудов и присутствие массы сосудов переходных типов, выделить критерии разделения, которых очень сложно.

Например, разделение сарматской посуды на группы по форме днища всегда достаточно условно, так как наблюдается масса переходных форм между плоскодонными и круглодонными сосудами, критерий же выделения степени уплощенности весьма размыт, и на рисунках обычно его очень сложно показать. Следует отметить, что уплощенность могла возникать непроизвольно при установке на дно еще сырого круглодонного сосуда в 
результате оседания и, таким образом, не иметь целенаправленный характер оформления дна (Краева, 2011. С. 55-56)

Встречается слишком много вариантов разнообразия на каждом этапе классификации и такая дробность затрудняет выделение наиболее информативных признаков.

Применение же методов статистического анализа показывает довольно слабую адаптированность их использования к изучению лепной керамики, что приводит к дроблению керамики на множество типов, которые часто визуально неотличимы друг от друга (Скрипкин, 1990. С. 30-58. Рис. 4-18; Берлизов, 2011. С. 72-79). И, к сожалению, данные методы не подходят для описания керамики.

Как известно, в сарматских захоронениях присутствует круговая импортная керамика, но большую часть составляет лепная посуда как местного, так и импортного производства (Краева, 2019. С. 137-138).

В настоящей статье предлагается систематизации сарматской лепной керамики в рамках формально-классификационного подхода, как более понятного и отличимого визуально для археолога.

Цель работы - разработка систематизации форм для создания определенного единого алгоритма описания сарматской керамики.

Предлагаемая систематизация форм и описания сложилась по ходу изучения технологии более 1500 сосудов с территории Южного Приуралья VII в. до н.э. - IV в. н.э. (включая Западный Казахстан), но данная система может быть использована и для других территорий.

Систематизация основана на обобщении уже существующих классификационных схем сарматской керамики, разработанных К.Ф. Смирновым, М.Г. Мошковой, А. С. Скрипкиным, М.А. Очир-Горяевой, В.М. Клепиковым, а также некоторых принципах классификации средневековой керамики Т.А. Хлеб- 
никовой (Мошкова, 1963. С. 24-30; Смирнов, 1964. С. 108-127; Скрипкин, 1984. С. 24-30; Очир-Горяева, 1991. С. 81-83; Клепиков, 2002. С. 50-54; Хлебникова, 1962. С. 93-152).

В систематизации употребляются общепринятые термины, известные по указанным выше работам исследователей. Отличие состоит в более строгой систематизации, использовании единой терминологии для описания керамики всех хронологических периодов сарматской культуры, а также в более дробном выделении таксономических единиц по оформлению шейки, венчика и придонной части, включая учет дополнительных скульптурных деталей на сосудах.

В систематизации не учитывается размерность и пропорции сосудов, так как эти данные относятся к числовым показателям, не рассматриваемым в настоящей статье. Они безусловно важны и возможно учитывать их в дальнейшем, внутри полученных разновидностей форм керамики.

Следует отметить, что описывая керамику, обязательно нужно указывать общий размер и размерность частей сосудов (высота, диаметр, ширина), а также толщину стенок и дна.

В основном, при названии конструктивных частей сосудов использовалась терминология, предложенная В. Ф. Генингом с привлечением некоторых элементов системы А.А. Бобринского (Генинг, 1973. С. 115-116; Бобринский, 1999. С. 11; Бобринский, 2018а. С. 27. Рис. 1).

Выделялись следующие конструктивные части сосуда (рис. 1, 1).

Дно - основание сосуда, служащая опорой на плоскости.

Поддон - выделенная часть дна, имеющая свою скульптурную форму в виде трапеции или полого цилиндра.

Придонная часть сосуда - часть сосуда, непосредственно прилегающая ко дну. 
Тулово - основная емкость сосуда.

Плечо - часть сосуда, находящаяся выше тулова и служащая добавочным наполнителем.

Шейка - суженная часть сосуда, опирающаяся на плечо и служащая для дозирования слива.

Венчик - часть сосуда, опирающаяся на тулово, плечо или шейку и служащая для устройства слива.

Срез венчика - верхнее окончание венчика.

Таксономическими единицами служили: категория, группа, отдел, тип, вид, вариант, внутри которых в некоторых случаях выделены дополнительные таксоны с приставкой «под» (подгруппа, подвариант и т.д.). Каждой таксономической единице и дополнительному таксону присваивается цифровое или буквенное значение (табл. 1).

Преимущество данной систематизации заключается в том, что она адаптирована для создания алгоритма описания керамики, а также может быть расширена и дополнена на каждом уровне по мере выявления новых разновидностей форм посуды. Так, в дальнейшем возможно выделение новых категорий керамики, особенно из многочисленной категории горшков, основываясь на форме, размерах и функциональном назначении сосудов.

Систематизация керамики представляет собой 6 уровней (табл. 1. рис. 1; 2). В результате, каждый сосуд может быть записан в виде буквенно-цифрового шифра и занесен в электронную таблицу (Excel).

Первый уровенъ. Все сосуды были разделены на 10 категорий: горшки, кувшины, чаши, блюда, миски, курильницы, керамические котелки, кружки, фляги, сосуды нестандартных форм.

В настоящей статье мы не рассматриваем такие категории как фляги, курильницы и сосуды нестандартных форм, как наиболее специфичные формы, которые требуют особого 
подхода, но описание данных сосудов с учетом предлагаемого алгоритма вполне возможно.

К горшкам отнесены сосуды с невысокой шейкой или без шейки с разнообразной формой тулова, иногда имеющие ручки или носики-сливы (рис. 3, 1-3).

Традиционно к кувшинам в сарматологии относят все сосуды с ручками. Мы предлагаем к кувшинам отнести сосуды разнообразной формы, с шейкой, высота которой приближается к 1/3 или даже равна 1/2 высоте тулова, иногда имеющие слив или ручки, утилитарного назначения (рис. 3, 4-5).

К чашам отнесены сосуды высотой до 15 см, у которых диаметр венчика значительно превышает диаметр дна (рис. 3, 6-7).

К блюдам отнесены емкости высотой до 5 см, имеющие широкое дно, практически равное диаметру венчика и невысокие прямые или слегка наклоненные внутрь стенки (рис. 3, 8).

К мискам отнесены сосуды высотой до 12 см, у которых максимальный диаметр венчика значительно больше высоты сосуда (рис. 3, 9).

Котелки - это керамические сосуды-подражания, распространенные в основном в позднесарматское время (отдельные экземпляры есть и в более раннее время), которые обладают целым рядом признаков, свойственным бронзовым котлам (Малашев, Яблонский, 2008. С. 49; Краева, 2019. С. 142) (рис. 3, 13-15).

Кружки - небольшие сосуды (высота до 15 см, диаметр венчика до 10-12 см) для питья, чаще имеющие форму усеченного конуса или цилиндра, либо иную форму, с одной ручкой, расположенной, как правило, в средней части тулова (рис. 3,16 ). Данная категория керамики, также как и котелки, характерна для более поздних комплексов сарматской культуры (Скрипкин, 1984. С. 144. Рис. 10, 4-5). Важно при выделении кружек уметь отделять их от горшков с ручками или кувшинчиков. 
Фляги - сосуды с овальной или уплощенно-овальной формой тулова в сечении и узким горлом, используемые для хранения и перевоза жидкости (рис. 3, 17). Как правило, в сарматских курганах находят импортные круговые фляги, но встречаются и лепные подражания им местного производства (Краева, 2019. С. 142-143).

Курильницы - небольшие сосудики, иногда нестандартной формы, используемые для курения различных веществ в религиозных целях (рис. 3, 10-12). Курильницы довольно специфичная категория сарматской керамики, которая, как уже отмечалось выше, требует отдельного подхода в изучении, поэтому в настоящей статье не рассматривается. Отметим только, что, на наш взгляд, в основу выделения такой категории как курильницы должны быть положены такие критерии как: 1) форма сосуда; 2) размеры сосуда до 10 см; 3) признаки горения содержимого в емкости сосуда в виде пригара или копоти.

Вполне возможно, что при более тщательном анализе маленьких сосудиков, ранее относимым к «курильницам», они не окажутся таковыми (Краева, 2016а. С. 48-55).

К сожалению, иногда трудно разделить курильницы и туалетные сосудики (Смирнов, 1973. С. 166-179). В таком случае на помощь могут прийти следы на внутренней и внешней поверхностях данных предметов: у туалетных сосудиков - это будут различные маслянистые пятна и следы краски, у курильниц следы нагара (Краева, 2015. С. 91-93).

Детальная же разработка критериев, позволяющих выделить туалетные сосудики как отдельную категорию сарматской керамики, еще предстоит.

Сосудики по форме похожие на горшки, но которые использовались для воскуривания, могут описываться и систематизироваться по схеме описания горшков внутри категории «курильницы». 
В категорию керамики «нестандартных форм» отнесены сосуды, редко встречающиеся среди сарматской керамики, имеющие необычную форму и не подходящие ни к одной из вышеописанных категорий (рис. 3, 18). Правда, из этой категории они могут быть со временем перенесены, если будет доказана их функциональная принадлежность. Так произошло с сосудами в виде вымени (Рис. 3, 11-12), которые были первоначально нами отнесены к сосудам нестандартных (редких) форм, а позже было доказано их отношение к курильницам (Краева, 2016б. С. 119-120. Рис. 3, 4)

Второй уровень. Все категории керамики разбиваются на 3 большие группы по форме дна, которые обозначены в классификационной таблице римскими цифрами: I - плоскодонные сосуды; II круглодонные сосуды; III - остродонные сосуды (табл. 1, рис. 1, 2).

При делении сосудов на группы мы руководствовались критерием возможности замера диаметра дна. К группе плоскодонной керамики отнесены сосуды, диаметр дна которых можно измерить. К круглодонной керамике отнесены сосуды с округлым днищем, диаметр дна которых измерить невозможно.

И, к сожалению, данные методы не подходят для описания керамики.

Было бы заманчиво со временем выделить сосуды с уплощенным дном, но для этого необходимо разработать четкие критерии уплощенности, которые, к сожалению, пока не найдены. Возможно, ими могут быть: характер оформления перехода дна в стенку, угол между точкой соприкосновения с поверхностью или количество точек соприкосновения с поверхностью.

Изучение технологии изготовления керамики показало, что целенаправленное уплощение дна производилось или постукиванием круглодонного сосуда о твердую поверхность или с помощью ударов по округлому дну специальным инструментом 
(колотушкой). В некоторых случаях «уплощенность» возникала в результате процесса конструирования.

Еще М.А. Очир-Горяева обратила внимание на особое оформление дна в савроматской керамике, назвав его выделенным (Очир-Горяева, 1990. С. 82-83). В отличии от сосудов с поддоном, у которых поддон выделялся отдельно и имел свою скульптурную форму в виде трапеции или полого цилиндра, при «выделенном» дне выпуклая часть тулова начиналась не прямо от основания дна, а на 0,8-2 см выше, отчего ниже него сосуд как бы был окружен невысоким уступчиком, образующим с плоскостью дна угол примерно 90 градусов (рис. 3, 1, 20-21). У сосудов с «невыделенным» дном переход между плоскостью дна и придонной частью плавный или образует тупой угол (рис. 3, 2, 4, 6, 22).

Описывая керамику, следует обращать внимание на переход дна в стенки: он может быть как плавный, так и четкий.

По особенностям оформления дна внутри групп выделяются подгруппы:

У плоскодонной керамики: 1 - прямое невыделенное дно; 2 - прямое выделенное дно; 3 - вогнутое невыделенное; 4 - вогнутое выделенное; 5 - сосуды с поддоном (кольцевым или сплошным) (табл. 1. рис. 1, 2).

Круглодонные сосуды могут быть разделены по степени уплощенности, но как уже отмечалось выше, критерии ее выделения пока отсутствуют.

Таким образом, в шифре группа может быть записана в виде индекса, обозначаемого римской цифрой, где I - плоскодонная керамика, II - круглодонная керамика, III - остродонная керамика, а арабскими цифрами - номер подгруппы по особенностям оформления дна, которая пока выделена только для плоскодонной посуды: $\mathrm{I}_{1}, \mathrm{I}_{2}, \mathrm{I}_{3}, \mathrm{I}_{4}, \mathrm{I}_{5}$. 
Третий уровень. На этом уровне каждая группа керамики разбивается на отделы по форме тулова, а также по высоте расположения максимального диаметра тулова (табл. 1. рис. 2). Использовались названия отделов, общепринятые в археологической литературе.

В классификационной таблице отделы обозначались арабскими цифрами (табл. 1).

Всего было выделено 7 отделов (рис. 2):

1 отдел - грушевидные сосуды (эллипсоидная форма с расширением в нижней части). Сосуды имеют расширяющееся книзу тулово, максимальный диаметр приходится на нижнюю часть.

2 отдел - яйцевидные сосуды (эллипсоидная форма с расширением в верхней части). Сосуды имеют расширяющуюся в верхней части форму тулова, максимальный диаметр в верхней трети тулова.

3 отдел - шаровидные сосуды. Сосуды с шаровидным или близким к нему туловом. Наибольший диаметр приходится на среднюю часть тулова.

4 отдел - вертикально-эллипсоидные сосуды. Сосуды, имеющие в профиле овальную форму тулова, растянутую по вертикали. Наибольший диаметр приходится на среднюю часть тулова. 5 отдел - горизонтально-эллипсоидные сосуды. Сосуды, имеющие в профиле овальную форму тулова, растянутую по горизонтали. Наибольший диаметр приходится на среднюю часть тулова.

6 отдел - биконические сосуды. Сосуды, тулово которых состоит как бы из двух усеченных конусов, соединенных своими широкими основаниями в основном в средней части тулова. Как правило, такие сосуды имеют четкое ребро перехода.

7 отдел - баночные. Баночной названа форма тулова с прямыми или слегка выпуклыми стенками. Наибольший диаметр приходится на венчик сосуда.

Часто оказывается, что исследователю трудно отнести 
сосуд к определённому отделу из-за сильной асимметричности тулова, когда с одной стороны, тулово вертикально-эллипсоидное, а с другой яйцевидное. В таком случае основанием отнесения к тому или иному отделу может служить преобладание того или иного признака при повороте сосуда вокруг своей оси или, в идеальном варианте, приведение сосуда к условной симметрии с помощью вычерчивания среднего контура, например, с помощью метода, предложенного А. А. Бобринским (Бобринский, 20186. С. 23)

Четвертый уровень. На этом уровне внутри отделов выделяются типы. В основу каждого типа было положено отсутствие или наличие шейки, а также ее форма при наличии.

В классификационной таблице типы обозначаются заглавными буквами, например: А, Б, В, Г, Е

Выделено 5 типов: А - без шейки; Б - плавно отогнутая; В - резко отогнутая (в этом случае наблюдается резкий переход от плеча к венчику); «Г» - прямая; «Д» - наклоненная внутрь; «Е»- выпуклая (табл. 1, рис. 1, 3).

При работе с керамикой было обращено внимание на наличие такого признака, особенно характерного для так называемых «тальковых сосудов», как внутреннее ребро (простое или более сложной конструкции) (рис. 3, 3). Данный признак не учитывается в нашей систематизации, но перед описанием керамики исследователю следует изучить внутренний контур сосуда.

Шейка может быть впоследствии также разделена по высоте при разработке дальнейшей классификации (например, короткая, средняя, длинная).

Пятьй уровень. На этом уровне выделяются виды по оформлению верхней части венчика (табл. 1. рис. 1, 4).

Отмечены 23 вида венчиков: 1 - прямой срезан по горизонтали; 2 - прямой округло-плоский; 3 - прямой заостренный; 
4 - прямой заостренный, скошенный к внутренней стороне; 5 - прямой скругленный, скошенный к внутренней стороне; 6 наклоненный наружу срезан по горизонтали; 7 - наклоненный наружу округлый; 8 - наклоненный наружу округло-плоский; 9 - наклоненный наружу заостренный; 10 - наклоненный наружу, скошенный к внешней стороне; 11 - наклоненный наружу с наплывом с внешней стороны; 12 - отогнут наружу, скошенный к внешней стороне; 13 - отогнут наружу округлый (округло-отогнутый); 14 - отогнут наружу заостренный; 15 - отогнут наружу под прямым углом; 16 - отогнут наружу закругленный, скошенный к внутренней стороне; 17 - отогнут наружу плоский, скошенный к внутренней стороне; 18 - отогнут наружу заостренный, скошенный к внутренней стороне; 19 - Т-образный (с наплывами с двух сторон); 20 - наклоненный наружу отогнутый с ребром с внешней стороны; 21 -наклоненный внутрь слегка заостренный; 22 - наклоненный внутрь с наплывом с внутренней стороны; 23 наклоненный внутрь с желобком с внутренней стороны.

Вид венчика выделяется как отдельный показатель и нумеруется в шифре арабскими цифрами.

Основная трудность определения оформления края венчика, как и степени уплощенности дна, заключается в том, что при описании в литературе этому не уделяется внимание, а по рисункам данные особенности не видно. В таком случае, если исследователь затрудняется с определением формы венчика, то может отказаться от классификации на этом уровне, записав его буквой «Х» в шифре.

Учитывая разнообразие видов венчика и трудность определения по рисункам, данный уровень систематизации можно пропустить, но при описании керамики ему следует уделить внимание.

Шестой уровенъ. По наличию у сосудов определенных скульптурных служебных частей керамика разбивается на варианты (табл. 1). 
Скульптурными названы детали, которые обычно располагаются на одном или нескольких участках боковой поверхности сосудов (Бобринский, 1999. С. 11).

Всего было выделено 4 варианта: а) сосуды без дополнительных скульптурных деталей (рис. 3, 1-3, 6, 8-10, 17); б) - сосуды со сливом (рис. 3, 19); в) - сосуды с ручками (рис. 3, 4-5, 13-14, 22-23); г) сосуды со сливом и ручками (рис. 3, 24-25).

По форме, количеству и месту расположения скульптурных деталей внутри вариантов возможно разделение на подварианты.

б) сосуды со сливом: 1 - с простым сливом по краю венчика (рис. 3, 19); 2 - со сложным фигурным сливом по краю венчика*; 3 - с трубчатым носиком сливом, сформованным в виде трубочки на плече (рис. 3, 20-21);

в) сосуды с ручками: 1 - с одной ручкой (рис. $3,4-5,22) ; 2$ с двумя ручками (рис. 3, 13-14, 23);

г) сосуды со сливом и ручками: 1 - с простым сливом и одной ручкой (рис. 3, 24); 2 - с простым сливом и двумя ручками; 3 - со сложным фигурным сливом и одной ручкой; 4 - со сложным фигурным сливом и двумя ручками; 5 - с трубчатым носиком сливом и одной ручкой; 6 - с трубчатым носиком сливом и двумя ручками (рис. 3, 25).

Таким образом в шифре вариант может быть записан в виде индекса, обозначаемого строчной буквой (а, б, в, г), номер подварианта - арабскими цифрами, например: $\sigma_{1}, \sigma_{2}, \sigma_{3}$.

Важно при описании керамики с ручками обращать внимание на место крепления ручки (ее верхней и нижней части), а также ее форму в целом (вертикальные, горизонтальные, петлевидные, зооморфные, ручки-ушки горизонтальные, ручки ушки вертикальные и т.д.) и форму сечения ручки (округлая, овальная,

* Сложные фигурные сливы, особенно характерны для импортной круговой керамики и лепных сосудов-подражаний им (Скрипкин, 1984. С. 138. Рис. 4, 8, 9) 
подпрямоугольная, подквадратная). Возможно, в дальнейшем необходимо будет ввести учет данных признаков в систематизацию.

Таким образом, учитывая предложенную систематизацию разновидность формы сосуда внутри категории можно будет записать по числовому коду. Например: $\mathrm{I}_{2}-2-5-12-\sigma_{3}$ (Горшок лепной, плоскодонный с прямым выделенным дном, яйцевидной формой тулова, плавно отогнутой короткой шейкой. Венчик отогнут наружу, скошен к внешней стороне. Сосуд имеет на плече трубчатый носик слив) (рис. 3, 21).

Использование шифра удобно при классификации керамики с помощью такой программы как Excel, где для каждой таксономической единицы и дополнительного таксона выделяются свои раздельные ячейки, которые могут быть задействованы в последующей фильтрации в программе по определённым признакам.

В случае, когда информация по какому-то таксону или дополнительному таксону отсутствует, она может быть заменена на «Х». Такой вариант возможен, если какая-то функциональная часть сосуда утрачена или исследователь по какой-то причине решил остановиться на определенном уровне и не учитывать все признаки. В не табличном варианте это будет выглядеть как I -2-Б-X-б.

Подводя итог, следует сказать, что конечно же представленная систематизация ни в коей мере не претендует на всеобъемлющую классификацию и требует дальнейшей апробации, в результате которой может быть дополнена и скорректирована. Надеемся, что ее использование позволит внести большую четкость и единообразие в описание сарматской керамики и поможет исследователям классифицировать материал. 


\section{ЛИТЕРАТУРА}

Бобринский А.А., 1999. Гончарная технология как объект историко-культурного изучения // Актуальные проблемы изучения древнего гончарства. Самара: Изд-во СамГПУ. С. 5-109.

Бобринский А.А., 2018а. Функциональные части в составе емкостей глиняной посуды // Формы глиняных сосудов как объект изучения. Историко-культурный подход / Отв. ред. Ю.Б. Цетлин. М.: ИА РАН. С. 26-37.

Бобринский А.А., 2018б. О методике изучения форм глиняной посуды из археологических раскопок // Формы глиняных сосудов как объект изучения. Историко-культурный подход / Отв. ред. Ю.Б. Цетлин. М.: ИА РАН. С. 11-25.

Генинг В.Ф., 1973. Программа статистической обработки керамики из археологических раскопок // СА. №1. С. 114-136.

Берлизов Н. Е., 2011. Ритмы Сарматии. Савромато-сарматские племена Южной России в VII в. до н.э.-V в. н.э. Краснодар: КГУКИ, Парабеллум. Ч І. 320 с.

Краева Л.А., 2007. Проблемы изучения сарматской керамики второй половины I тыс. до н. э. // Формирование и взаимодействие уральских народов в изменяющейся этнокультурной среде Евразии: проблемы изучения и историография. Уфа: Изд-во «Китап». С. 257-265.

Краева Л.А. 2011. Технология изготовления керамики из погребений раннесарматской культуры Южного Приуралья // Археология, этнография и антропология Евразии. №4 (48). С. 51-60.

Краева Л.А., 2015. Бытовое и сакральное использование керамики у сарматов Южного Приуралья и Западного Казахстана // Самарский научный вестник. №3 (12). С. 90-99.

Краева Л.А., 2016а. «Курильницы» с одним боковым отверстием // Религия и система мировоззрений древних и сред- 
невековых номадов Евразии / Отв. ред. А. Онгарулы. Алматы: Институт археологии им. А.Х. Маргулана. С. 48-55.

Краева Л.А., 2016б. Технология изготовления и способы использования некоторых типов сарматских курильниц // Константин Федорович Смирнов и современные проблемы сарматской археологии. Материалы IX Международной научной конференции «Проблемы сарматской археологии и истории» / Отв. ред. Л.Т. Яблонский, Л.А. Краева. Оренбург: Изд-во ОГПУ. С. 113-121.

Краева Л.А. 2018. Гончарное производство сарматских племен Западного Казахстана и проблемы изучения // Археология ранних кочевников Евразии / Под общ. ред. В. Н. Мышкина. Самара: ООО «Книжное издательство». С. 140-150.

Краева Л.А., 2019. Заимствования и подражания в гончарстве сарматских племен Южного Приуралья и Западного Казахстана // Крым в сарматскую эпоху (II в. до н.э.-V в. н.э). V. Материалы X Международной научной конференции «Проблемы сарматской археологии и истории» / Отв. ред. И.Н. Храпунов. Симферополь: ООО «Фирма «Салта» ЛТД». С. 136-146.

Клепиков B.M., 2002. Сарматы Нижнего Поволжья в IVIII вв. до н.э. Волгоград: Изд-во ВолГУ. 216 с.

Малашев В.Ю., Яблонский Л.Т., 2008. Степное население Южного Приуралья в позднесарматское время: по материалам могильника Покровка 10 / Отв. ред. М.Г. Мошкова. М.: ИА PAH. 365 c.

Мошкова М.Г., 1963. Памятники прохоровской культуры // САИ. Д1-10 М.: Наука. 56 с.

Мошкова М.Г. 1989. История изучения савромато-сарматских племен // Археология СССР. Степи европейской части СССР в скифо-сарматское время. М.: Наука. С. 158-164.

Очир-Горяева М.А., 1990. Классификация керамики из погребений скифской эпохи Нижнего Поволжья // Вопросы 
археологии юга Восточной Европы. Элиста: Изд-во Калмыцкого ун-та. С. 81-92.

Скрипкин А.С., 1984. Нижнее Поволжье в первые века нашей эры / Ред. М.Г. Мошкова. Саратов: Изд-во Сарат. ун-та. 240 с.

Скрипкин А.С., 1990. Азиатская Сарматия. Саратов: Издво Сарат. ун-та. 240 с.

Смирнов К.Ф., 1964. Савроматы. М.: Наука. 379 с.

Смирнов К.Ф., 1973. Курильницы и туалетные сосудики Азиатской Сарматии // Кавказ и Восточная Европа в древности / Отв. ред. Р.М. Мунчаев и В.И. Марковин. М.: Наука. С. $166-179$.

Хлебникова Т. А., 1962. Гончарное производство волжских болгар X-начала XIII вв. // Труды Куйбышевской экспедиции. МИА. №111. С. 93-152.

\section{СПИСОК СОКРАЩЕНИЙ:}

МИА - Материалы и исследования по археологии СССР

САИ - Свод археологических источников

ОГПУ - Оренбургский государственный педагогический университет

СамГПУ - Самарский государственный педагогический университет

\section{СВЕДЕНИЯ ОБ АВТОРЕ:}

Краева Людмила Анатольевна, кандидат исторических наук, Оренбургский государственный педагогический университет, Оренбург, Россия, e-mail: kraeva ludmila@mail.ru 


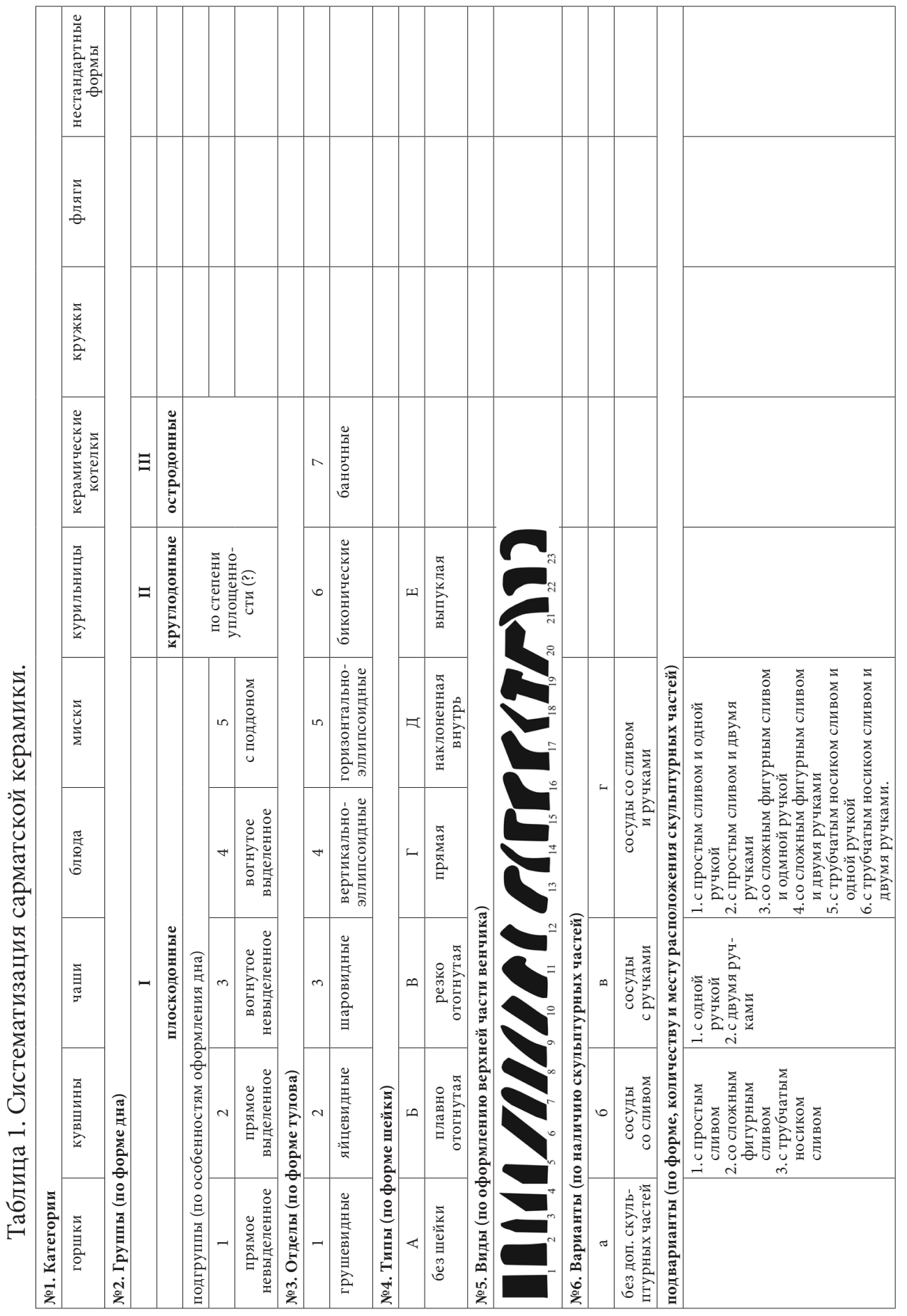



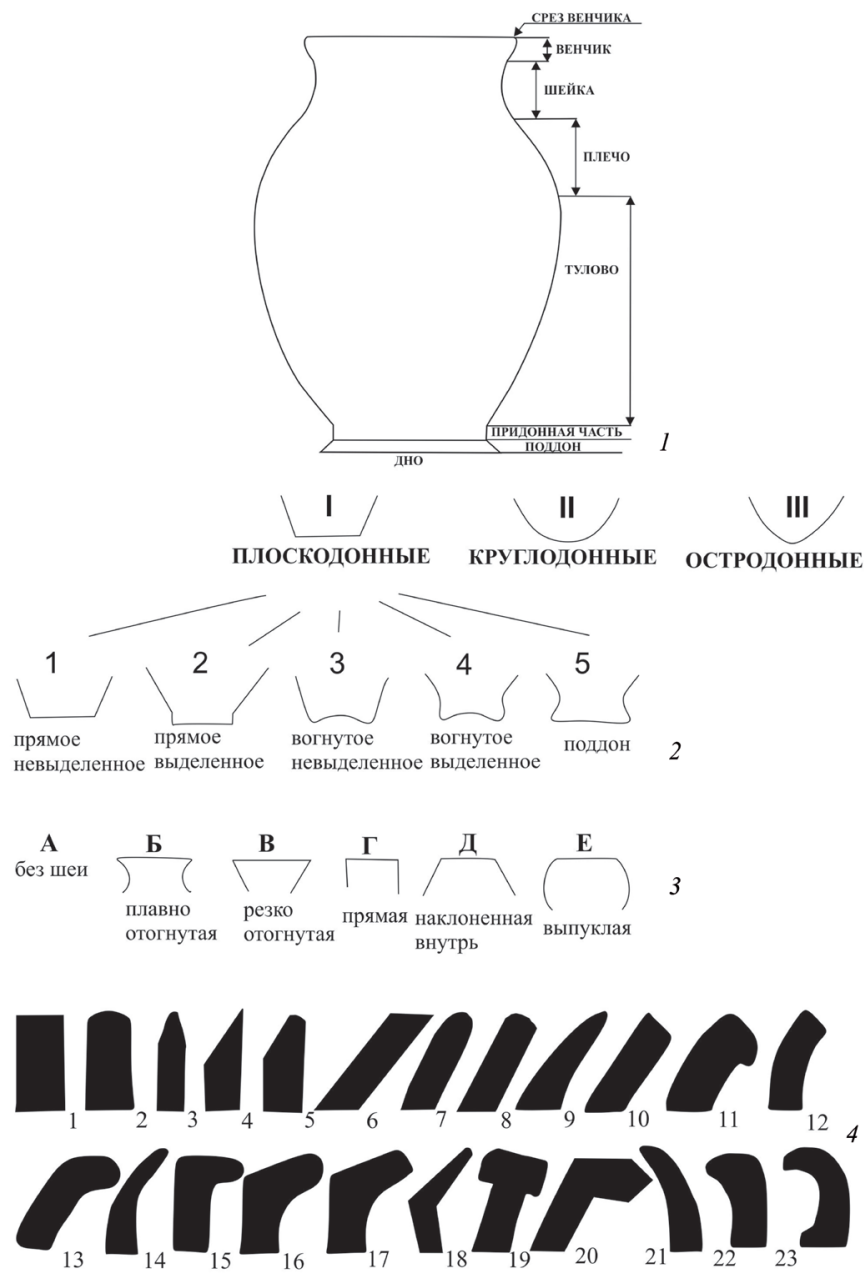

Рис. 1. Систематизация сарматской керамики: 1 - схема конструктивных частей сосуда; 2 - группы и подгруппы керамики по оформлению дна; 3 - типы керамики по форме шейки; 4 - виды керамики по оформлению верхней части венчика. 


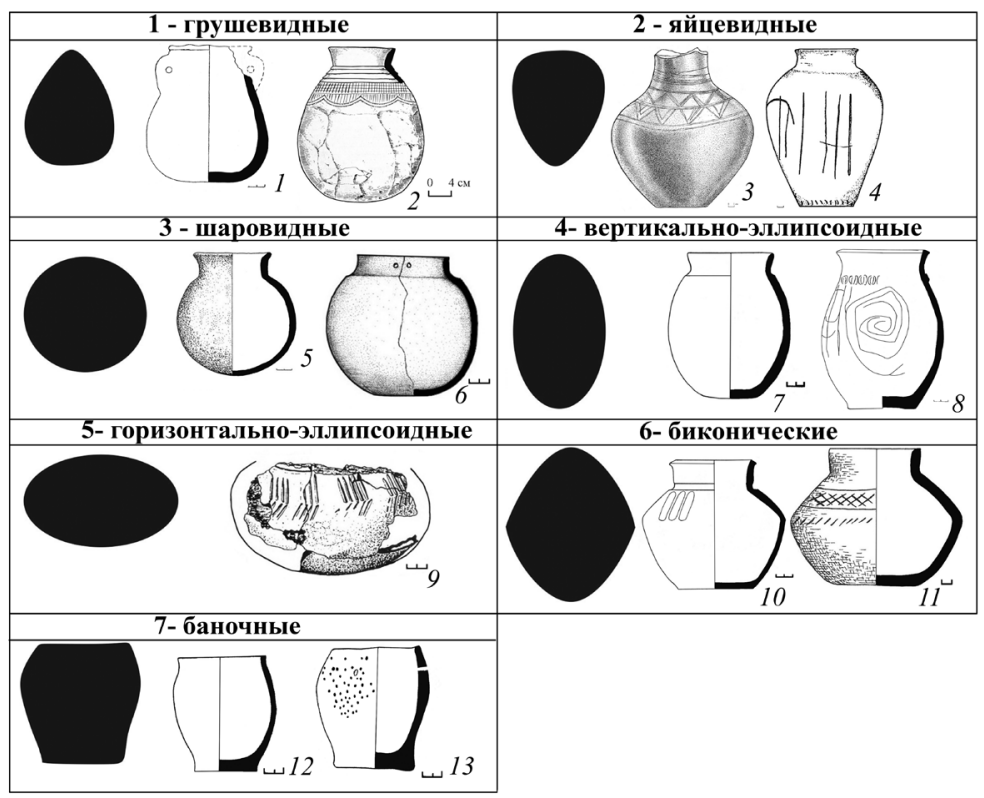

Рис. 2. Отделы керамики по форме тулова: 1 - Болдырево 1 к. 6; 2 - Мечет-Сай к. 8. п. 1; 3 - Прохоровка к. «б» п. 9; 4 - Шумаево 1 к. 7 п. 3 сосуд 1; 5 - Покровка 2 к. 7 п. 3; 6 - Шумаево 2 к. 3 п. 4; 7 - Мечет-Сай к. 3 п.7; 8 - Липовка к. 3 п. 1; 9 - Черный Яр к. 20 п. 4 с. 3; 10 - Мечет-Сай к. 3 п. 2; 11 - Покровка 8 к. 6 п.1; 12 Покровка 2 к. 25 п. 1; 13 - Медведка к. 7 п. 2. 


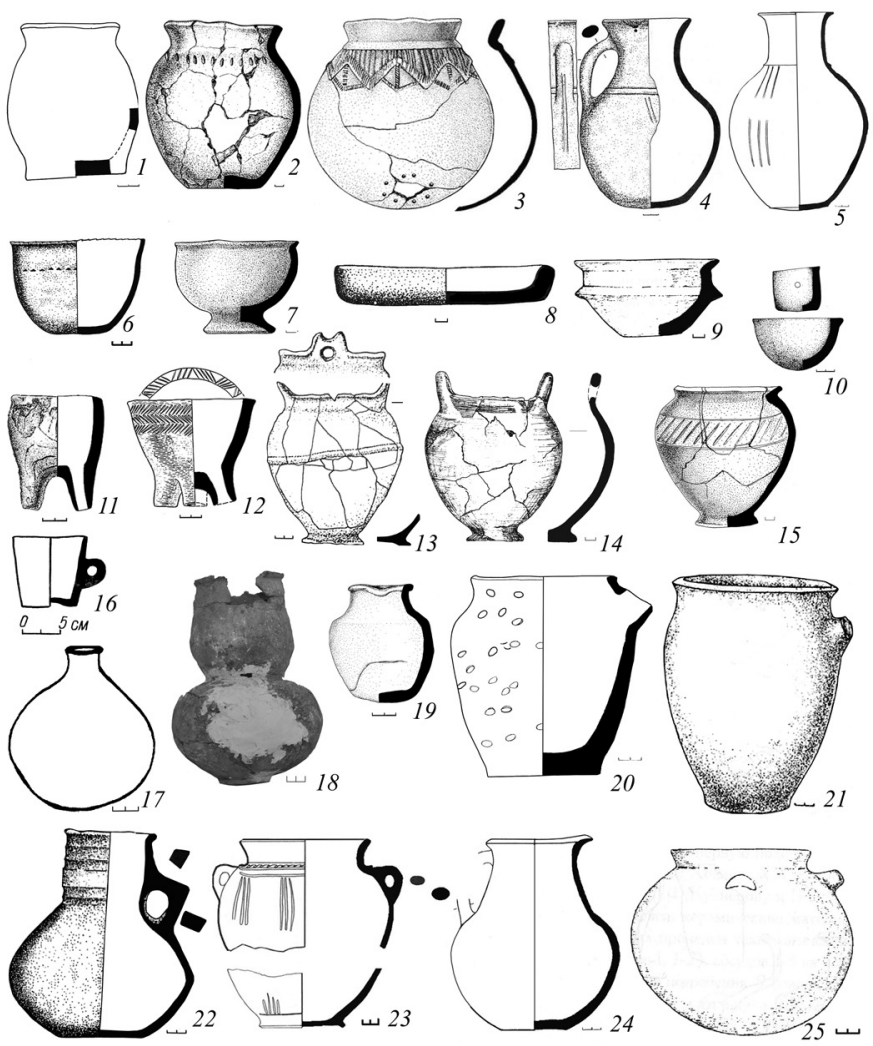

Рис. 3. Сарматская керамика: 1 - Чкаловский к. 4 п. 2; 2 - Шумаево 2 к. 9 п. 17; 3 - Прохоровка к. «б» п. 26; 4 - Покровка 1 к. 3 п. 6; 5 - Чкаловский к. 3 п. 7; 6 - Покровка 1 к. 16 п. 2; 7 - Шумаево 2 к. 9 п. 14; 8 - Покровка 2 к. 23 п. 9; 9 - Бердянка 5 к. 5 п. 3 сосуд 2; 10 Шумаево 1 к. 3 п. 2; 11 - Акоба 2 к. 1 п. 3 сосуд 3; 12 - Филипповка к. 7 скелет 3; 13- Покровка 10, к. 66; 14 - Красный Яр к. 20; 15 - Акоба 5 к. 1 п. 2 сосуд 4; 16 - Сидоры к. 25; 17 - Кардаилово к. 3 п. 1; 18 - Уркач 1 к 25 п. 1 сосуд 4; 19 - Прохоровка к. 4 п. 2 сосуд 2; 20 - Липовка к. 9 п. 3; 21 - Медведка к. 8; 22 - Покровка 10 к. 85; 23 - Чкаловский к. 4 п. 13; 24 - Чкаловский к. 3 п. 1; 25 - Бердянка 5 к. 5 п. 6 сосуд 1. 


\section{М.В. Кривошеев}

\section{Южное Приуралье и Нижнее Поволжье в позднесарматское время. Вопросы взаимодействия*.}

Резюме. В работе проводится сравнительный анализ позднесарматских памятников с территории волго-донского региона и Южного Приуралья. Оба региона имели особенности развития культуры, но уверенно можно говорить об их политической и экономической близости. В каждом из них в первой половине III в. формируется собственный политический центр. Во второй половине III в. отмечается появление в волго-донских памятниках вещей южноуральских форм, что можно связать с оттоком населения из Южного Приуралья, вызванного неблагоприятными климатическими изменениями.

Ключевые слова: Южное Приуралье, Нижнее Поволжье, позднесарматская культура, миграция, погребальный обряд

\section{M.V. Krivosheev}

\section{Southern Cis-Urals and Lower Volga region during Late Sarmatian Age. Aspects of interaction*.}

The paper deals with comparative analysis, which is being undertaken for the Late Sarmatian sites over vast territory of Volga and Don rivers basin and Southern Cis-Urals. Both areas are of particular

\footnotetext{
* Работа выполнена при поддержке гранта РФФИ № 19-09-00471 «Палеоантропология древнего и средневекового населения Нижнего Поволжья (палеопатологический аспект)».
} 
cultural development, but certainly were politically and economically connected. During the first half of the III century AD each region had rising political center. The second half of the III century AD is marked by appearance of artifacts of the South-Uralian origin in archaeological sites as far as Volga and Don rivers basin. This might be linked with population shift from the Southern Cis-Urals provoked by unfavorable climatic changes.

Keyword: The Southern Cic-Urals, Lower Volga region, Late Sarmatian culture, migration, funerary ritual.

В 1994 г. вышла статья М.Г. Мошковой, в которой был поставлен вопрос о рассмотрении южноприуральской и волго-донской групп памятников позднесарматского времени как двух локальных вариантов или двух разных культур (Мошкова, 1994). Уже тогда Мариной Глебовной были отмечены основные различия между памятниками этих двух регионов, выраженные в доминировании разных типов ям, в высоком проценте южной ориентировки в волго-донских степях. При этом отмечалась близость материальной культуры. Объяснялось такое положение дел различной основой, с которой взаимодействовали носители позднесарматской культуры в период её формирования. В Южном Приуралье на момент появления позднесарматских племен местное население среднесарматского времени было малочисленным и не повлияло на формирование новой культуры. В Поволжье «инновации ... ложились на мощный местный культурный пласт» (Мошкова, 1994. С. 22). Более поздние исследования подтвердили это предположение (Малашев, Яблонский, 2008; Малашев, 2013).

В финале своей статьи М.Г. Мошкова предположила возможность разделения волго-донских и южноуральских памятников на две самостоятельные культуры, но, возможно, в рамках 
единого политического объединения во второй половине II первой половине III в. н.э. (Мошкова, 1994. С. 23).

В данной работе хотелось бы, опираясь на новые данные, остановиться на вопросах взаимодействия кочевых групп двух упомянутых регионов.

Отдельные элементы погребального обряда указывают на восточные корни позднесарматской культуры. Однако вопрос о её происхождении до сих пор открыт. Имеющиеся версии о начальной территории сложения позднесарматского археологического комплекса пока не нашли однозначных подтверждений (Малашев, Мошкова, 2010; Скрипкин, 2012; Малашев, 2013).

Позднесарматская культура в наиболее чистом виде представлена в Южном Приуралье, где она появилась около сер. II в. уже с набором всех присущих ей признаков (Малашев, Яблонский, 2008; Малашев, 2013). В волго-донском регионе процесс взаимодействия с предшествующим среднесарматским населением сильно видоизменил облик культуры. Однако достаточно серьёзные отличия средне- и позднесарматских традиций позволяют наблюдать процесс диффузии двух культур на протяжении второй половины II в. н.э. Это взаимодействие не было однозначно мирным. Появление позднесарматских кочевников на территории Заволжья привело к значительному оттоку среднесарматского населения в Волго-Донское междуречье (Кривошеев, 2010. С. 62).

Для территории волго-донского региона можно выделить период формирования позднесарматской культуры во второй половине II в. н.э. Процесс культурогенеза здесь имел двухкомпонентную основу среднесарматских и позднесарматских традиций. Анализ материала показывает сложный процесс взаимопроникновения обрядовых норм. В итоге мы наблюдаем во второй половине II - первой половине III вв. н.э. в Волго-Донском междуречье 
доминирование южной ориентировки погребенных, что указывает на мощный субстратный пласт среднесарматского населения.

Судя по материалу, в нижнедонском регионе традиции предшествующей культуры в меньшей степени влияли на сложение позднесарматского культурного комплекса. Здесь процесс становления культуры происходил значительно интенсивнее: уже во второй половине II в. н.э. практически исчезают погребальные традиции среднесарматской культуры и ведущее положение занимают погребения с чертами «классической» позднесарматской культуры (Кривошеев, 2005. С. 187).

Своеобразная диспропорция в развитии позднесарматской культуры в южноуральском и волго-донском регионах начинает выравниваться к началу III в. н.э. Позднесарматские черты занимают доминирующие позиции в погребальном обряде на всей территории её распространения. Среднесарматские традиции практически исчезают из погребального обряда. Для периода первой половины III в. н.э. не возникает сомнений в целостности культурного пространства от Приуралья до Нижнего Дона и если не в политическом единстве, то близости облика.

Аргументом в пользу единства торгово-экономических связей различных регионов могут выступать импортные вещи. Во второй половине II-III вв. н.э. в позднесарматских памятниках Южного Приуралья встречается значительное количество керамики из производственных центров Северного Кавказа (Малашев, 2013. С. 37-50). Аналогичные формы широко распространены на территории волго-донского региона (рис. 1).

Во всем ареале позднесарматской культуры надежными хроноиндикаторами выступают фибулы северопричерноморского, кавказского и нижнедонского производства. Основные типы застежек у кочевников резко меняются в позднесармат- 
ское время. Они получают широкое распространение как в волго-донских степях, так и в Южном Приуралье (рис. 2). Аналогичная картина наблюдается и с зеркалами-подвесками, которые так же распространены во всех регионах (рис. 2).

Единые элементы и детали ременной гарнитуры становятся хорошим хроноиндикатором от Приуралья до Подонья и независимо от их происхождения синхронизируют комплексы позднесарматской культуры (Малашев, 2000).

Маркером политической близости двух регионов также могут выступать яркие воинские комплексы, которые указывают на наличие в позднесарматской среде неких мужских воинских коллективов, функции которых пока не вполне ясны, но которые четко выделяются из среды рядовых кочевников (Высочино VII, Таксай I, Камышевский I, Конезавод, Ковалевка) (Безуглов, 1997; 2000; 2017; Зубов, Багаутдинов, 2019; Дьяченко, Кривочеев, 2014). Их отличает ярко выраженный воинский характер, нередко указывающий на принадлежность к кругу профессиональных воинов выраженный в сочетании элементов вооружения, ременной гарнитуры, деталей отделки мечей, конской узды, импортных вещей (Кривочеев, 2020). Аналогичные комплексы, наиболее яркие из которых происходят с территории Нижнего Дона, встречаются в разных регионах распространения позднесарматской культуры.

К первой половине III в. относится большое количество находок импортных вещей античного производства. В первую очередь, это римская металлическая посуда и эмалевые фибулы (Кривошеев, 2014; Трейстер, 2016). Они, как правило, маркируют статусные комплексы, в том числе воинского круга. Их ареал охватывает территорию от Нижнего Дона до Зауралья. Находки таких вещей в наиболее удаленных зауральских памятниках (Магнитный кург. 23, погр. 1) также могут указывать на участие этих кочевых групп или их представителей в контактах с античной периферией. 
В условиях единства позднесарматского мира во второй половине II- первой половине III вв. можно отметить и специфические черты двух позднесарматских групп. Уже упоминались различия в их формировании. Стоит сказать и о географической обусловленности. Маршруты кочевания сарматских племен, как правило, выстраивались в меридиональном направлении. Позднесарматские кочевники волго-донского региона в этом случае вступали в контакты с производственными центрами Северного Кавказа, Нижнего Дона, откуда к ним и поступала основная масса импортных вещей.

Маршруты кочевания южноуральских номадов доходили до среднеазиатских территорий. Это может объяснить появление в первой половине III в. н.э. на этой территории находок керамических изделий среднеазиатского производства (Мошкова, 1987), зеркал с центральной петелькой, выполненных как подражание китайским образцам. Такие зеркала могли производиться в среднеазиатских мастерских. К западу от Волги эти вещи практически не попадали (Малашев, Яблонский, 2008; Малашев, 2013).

В обрядовом плане приуральская группа памятников также имеет специфические черты, которые не находят аналогии к западу от Волги. Это использование огня в погребальном обряде, наличие кольцевых насыпей на территории могильников, гантелеобразных насыпей и др. (Малашев, 2013).

Для первой половины III в. н.э. можно говорить о формировании двух центров племенных объединений в позднесарматском мире. Один находился в низовьях Дона. Здесь обнаружены наиболее статусные захоронения в таких могильниках как Валовый I, Новоалександровка, Высочино. Другой центр связан с территорией Южного Приуралья. Могильник Лебедёвка демонстрирует погребения высшей аристократии этой группы. Веро- 
ятно, в зону влияния приуральского центра входила и территория Заволжья (Кривошеев, Малашев, в печати).

Определить степень подчиненности или независимости этих групп в отношении друг друга в политическом отношении пока не представляется возможным.

Середина III в. н.э. стала переломным моментом в истории позднесарматской культуры. В результате перемещения на Нижний Дон выходцев с территории Северного Кавказа, носителей обряда захоронения в Т-образных катакомбах, здесь были разрушены поселения меотов и античный город Танаис. С этого момента в степных памятниках значительно меняется вещевой инвентарь: в степи появляются новые типы фибул, деталей ременной гарнитуры, иных категорий инвентаря (Кривошеев, Maлашев, 2016). На территории Нижнего Дона и в северной части Волго-Донского междуречья черты позднесарматской погребальной традиции постепенно вытесняются новыми, северокавказскими. Подбойные могилы к началу IV в. н.э. практически исчезают (Малашев, 2009).

На территории южной части Волго-Донского междуречья, преимущественно в астраханском правобережье, отмечается появление достаточно крупных могильников типа Кривая Лука XVII, в которых отсутствуют Т-образные катакомбы. Можно предположить существование во второй половине III в. н.э. в волго-донских степях двух политически самостоятельных групп кочевников, одна из которых связана с выходцами с Северного Кавказа, обосновавшимися в низовьях Дона и северной части Волго-Донского междуречья. Другая - с позднесарматским населением, оставившим могильники на правобережье Волги, в которых доминируют северная ориентировка, узкие прямоугольные и подбойные могилы. В условиях обитания на близких территориях, вероятно, происходила некая диффузия в контакт- 
ной зоне, при которой катакомбный обряд захоронений воспринимался в группе позднесарматского населения.

После середины III в. н.э. в южной части Волго-Донского междуречья стали появляться вещи, которые не были характерны для этого региона в предыдущее время. В 2000 г. Марина Глебовна, разбирая позднесарматские застежки, указала, что коленчатые фибулы, датируемые концом II-III вв. н.э. (Мошкова, 2000. С. 191; Малашев, 2013), характерны исключительно для кочевников южноуральской группы и к западу от Волги не встречаются (Мошкова, 2000. С. 190). Однако сейчас появились новые материалы, указывающие на присутствие таких фибул в могильниках междуречья во второй половине III в. н.э. (Кривая Лука XVII кург. 17 (рис. 3,1), кург. 30 (рис. 3,2); Дюкер кург. 20 (рис. 3,3)).

Также в могильниках второй половины III в. н.э. отмечается появление типов лепной керамики, которая морфологически сходна с формами, распространенными в Южном Приуралье (рис. 3,4-18). Она отличается прямым вертикальным горлом, как правило, без выделенного венчика, практически горизонтальными плечиками и красноватым цветом поверхности, что связано с особенностями обжига. До сер. III в. такая керамика в волго-донских памятниках мне неизвестна.

Можно сделать предположение относительно причин появления вещей южноуральского происхождения в Волго-Донских степях.

В свой работе по позднесарматским памятникам Южного Приуралья В.Ю. Малашев ограничил верхнюю границу их существования второй половиной III в. н.э. без финала столетия (Малашев, 2013. С. 130). Для Нижнего Поволжья к IV в. можно отнести лишь единичные захоронения. Совсем недавно было предложено возможное объяснение отсутствия памятников IV в. н.э. в Приуралье и их резкое сокращение в Волго-Донских степях. 
По данным палеопочвоведения в Нижнем Поволжье во второй половине II - первой половине III в. н.э. климат отмечен аридными условиями благоприятными для ведения кочевого скотоводства в степной зоне. Во второй половине III - на рубеже III-IV вв. отмечаются процессы гумидизации, связанные с увеличением увлажненности климата. Достаточная обводнённость территории, высокий травостой благоприятны для летнего выпаса скота. Однако зимы с частыми оттепелями, дождями, туманами, сменяющимися похолоданиями с обильными снегопадами, метелями, гололёдом, формированием ледяной корки и увеличением мощности снегового покрова приводят к катастрофическим последствиям в условиях кочевого скотоводства, вплоть до полной потери стада (Кривошеев, Борисов, 2019). Предполагаемые процессы гумидизации в первую очередь отразились на климате в Южном Приуралье и в финале III в. н. э. достигли волго-донских степей.

Нарастающие неблагоприятные условия могли стать причиной оттока позднесарматского населения из Южного Приуралья в районы Поволжья во второй половине III в. н.э. Не исключено, что появление приуральских вещей в Поволжье стало отражением движения кочевников из Южного Приуралья в районы Поволжья.

B IV в. н.э. степи от Приуралья до Нижнего Дона практически обезлюдили.

Подводя итог вышесказанному, хотелось бы вернуться к тезисам, высказанным Мариной Глебовной по поводу возможности выделения двух культур или двух вариантов позднесарматской культуры. На мой взгляд, на имеющихся сейчас данных стоит говорить о единой позднесарматской культуре, имеющей специфические особенности на разных этапах своего развития в каждом регионе. Во второй половине II - первой половине III в. эти регионы тесно связаны как основными культурными мар- 
керами, так и устойчивыми торговыми связями, демонстрируя единство по типу сообщающихся сосудов.

При ухудшении климатических условий в южноуральском регионе во второй половине III в. н.э. отток населения оттуда в степи Волго-Донского междуречья делает её ещё более монолитной. Вычленить южноуральский компонент в этом монолите крайне сложно, что говорит в пользу культурного единства двух слившихся групп кочевников.

Во второй половине II - первой половине III вв. н.э. уровень развития кочевых сообществ вряд ли позволял создать политическое объединение в рамках всего ареала позднесарматской культуры. Можно предположить существование в этот период как минимум двух крупных центров власти в Южном Приуралье и на Нижнем Дону, к которым могли тяготеть менее влиятельные образования (Заволжье, северная часть Волго-Донского междуречья).

\section{ЛИТЕРАТУРА}

Безуглов С.И., 1997. Воинское позднесарматское погребение близ Азова // Историко-археологические исследования в Азове и на Нижнем Дону в 1994 г. Вып. 14. Азов: С. 133-142.

Безуглов С.И., 2000. Позднесарматские мечи (по материалам Подонья) // Сарматы и их соседи на Дону / Отв. ред. Ю.К. Гугуев. Ростов-на-Дону: Терра. С. 169-193.

Безуглов С.И., 2017. Позднесарматский курган у станицы Камышевской на Дону // Вестник Танаиса. Вып. 4 / Отв. ред. В.И. Перевозчиков. Хутор Недвиговка Мясниковского района Ростовской области: АМЗ «Танаис». С. 84-127.

Дьяченко А.Н., Кривошеев М.В., 2014. Погребение воина позднесарматского времени в Волго-Донском междуречье // Военная история России: проблемы, поиски, решения: материалы 
Междунар. науч.-практ. конф., посвящ. 100-летию Первой мировой войны, г. Волгоград, 26-27 сент. 2014 г. / Отв. ред. С. Г. Сидоров. Волгоград: Изд-во ВолГУ. С. 42-49.

Зубов С.Э., Багаутдинов Р.С., 2019. Новые материалы позднесарматского времени в Самарском Заволжье (курганный могильник Конезавод 1) // Крым в сарматскую эпоху (II в. до н.э. - V в. н.э.). V. Материалы X Международной научной конференции «Проблемы сарматской археологии и истории» / Отв. ред. И.Н. Храпунов. Симферополь: ООО «Фирма «Салта» ЛТД». С. 103-111.

Кривошеев М.В., 2005. Позднесарматская культура южной части междуречья Волги и Дона. Проблемы хронологии и периодизации. Диссертация на соискание ученой степени кандидата исторических наук. Волгоград. 336 с.

Кривошеев М.В., 2010. Вопросы происхождения и развития позднесарматской культуры в Нижнем Поволжье // Становление и развитие позднесарматской культуры (по археологическим и естественнонаучным данным). Материалы семинара Центра изучения истории и культуры сарматов. Выпуск III / Отв. ред. А.С. Скрипкин. Волгоград: Изд-во. ВолГУ. С. 57-92.

Кривошеев М.В., 2014. Импортная металлическая посуда как маркер знатных погребений позднесарматского времени // Материалы VIII Всероссийской (с международным участием) конференции «Проблемы сарматской археологии и истории», Уфа, ИИЯЛ УНЦ РАН, 12-15 мая 2014 г. / Отв. ред. Л.Т. Яблонский, Н.С. Савельев (УАВ Вып. 14). Уфа: ИИЯЛ УНЦ РАН, Центр «Наследие». С. 105-112.

Кривошеев М.В., 2020. К вопросу о существовании профессиональных воинов у кочевников позднесарматского времени // Археологическое наследие. № 1 (3). Античность. Скифы. Сарматы. С. 317-324.

Кривошеев М.В., Малашев В.Ю., 2016. Хроноиндикаторы 
середины III-IV вв. н.э. из степных памятников Волго-Донского региона // Античная цивилизация и варварский мир Понто-Каспийского региона: материалы Всероссийской научной конференции с международным участием, посвященной 70-летнему юбилею Б.А. Раева (Кагальник, 20-21 октября 2016 г.) / Отв. ред. С.И. Лукьяшко. Ростов-на-Дону: Изд-во ЮНЦ РАН. С. 138-147.

Кривошеев М.В., Борисов А.В., 2019. Климатический оптимум как фактор кризиса экономики степных номадов в IV в. н.э. // Вестник Волгоградского государственного университета. Серия 4, История. Регионоведение. Международные отношения. Т. 24, № 3. C. 47-57. DOI: https://doi.org/10.15688/jvolsu4.2019.3.4

Кривошеев М.В., Малашев В.Ю. «Позднесарматские памятники Волго-Уральского региона» // Археология Волго-Уральского региона. Том 4. Казань. В печати.

Малашев В.Ю., 2000. Периодизация ременных гарнитур позднесарматского времени // Сарматы и их соседи на Дону / Отв. ред. Ю.К. Гугуев. Ростов-на-Дону: Терра. С. 194-232.

Малашев В.Ю., 2009. Позднесарматская культура: верхняя хронологическая граница // РА. № 1 . С. 47-51.

Малашев В.Ю., 2013. Позднесарматская культура Южного Приуралья во II-III вв. н.э. Диссертация на соискание ученой степени кандидата исторических наук. М. 301 с.

Малашев В.Ю., Яблонский Л.Т., 2008. Степное население Южного Приуралья в позднесарматское время. По материалам могильника Покровка 10. М.: Восточная литература. 365 с.

Малашев В.Ю., Мошкова М.Г., 2010. Происхождение позднесарматской культуры (к постановке проблемы) // Становление и развитие позднесарматской культуры (по археологическим и естественнонаучным данным). Материалы семинара Центра изучения истории и культуры сарматов. Вып. III. / Отв. ред. А.С. Скрипкин. Волгоград: Изд-во. ВолГУ. С. 37-56. 
Мошкова М.Г., 1987. Среднеазиатская керамика из позднесарматских комплексов // Прошлое Средней Азии (археология, нумизматика и эпиграфика, этнография) / Отв. ред. В.А. Ранов. Душанбе: Дониш. С. 104-112.

Мошкова М.Г., 1994. К вопросу о двух локальных вариантах или культурах на территории Азиатской Сарматии во II-IV вв. н.э. // Проблемы истории и культуры сарматов / Ред. А.С. Скрипкин. Волгоград: Изд-во ВолГУ. С. 18-23.

Мошкова М.Г., 2000. Фибулы из позднесарматских погребений Южного Приуралья: вопросы хронологии и производства // Нижневолжский археологический вестник. Вып. 3. С. 186-200.

Скрипкин А.С., 2012. Позднесарматская культура (проблемы исследования) // Евразия в скифо-сарматское время. Памяти Ирины Ивановны Гущиной. Труды ГИМ. Вып. 191. / Отв. ред. Д.В. Журавлев, К.Б. Фирсов. М., 2012. С. 239-243.

Трейстер М. Ю., 2016. Провинциально-римские шарнирные броши с эмалью и мозаичным стеклом в позднесарматских погребениях Урала и Западного Казахстана // Актуальные проблемы археологии Евразии. Сборник материалов международной научно-практической конференции, посвященной 25-летию независимости Республики Казахстан и 25-летию Института археологии им. А.Х. Маргулана / Отв. ред. Б.А. Байтанаев. Алматы: ИА им. А.Х. Маргулана. С. 345-354.

\section{СВЕДЕНИЯ ОБ АВТОРЕ.}

Кривошеев Михаил Васильевич, кандидат исторических наук, Волгоградский государственный университет, Волгоград, Россия, e-mail: arhlab@volsu.ru, tyaf@mail.ru, https:/orcid. org/0000-0003-4847-8209 


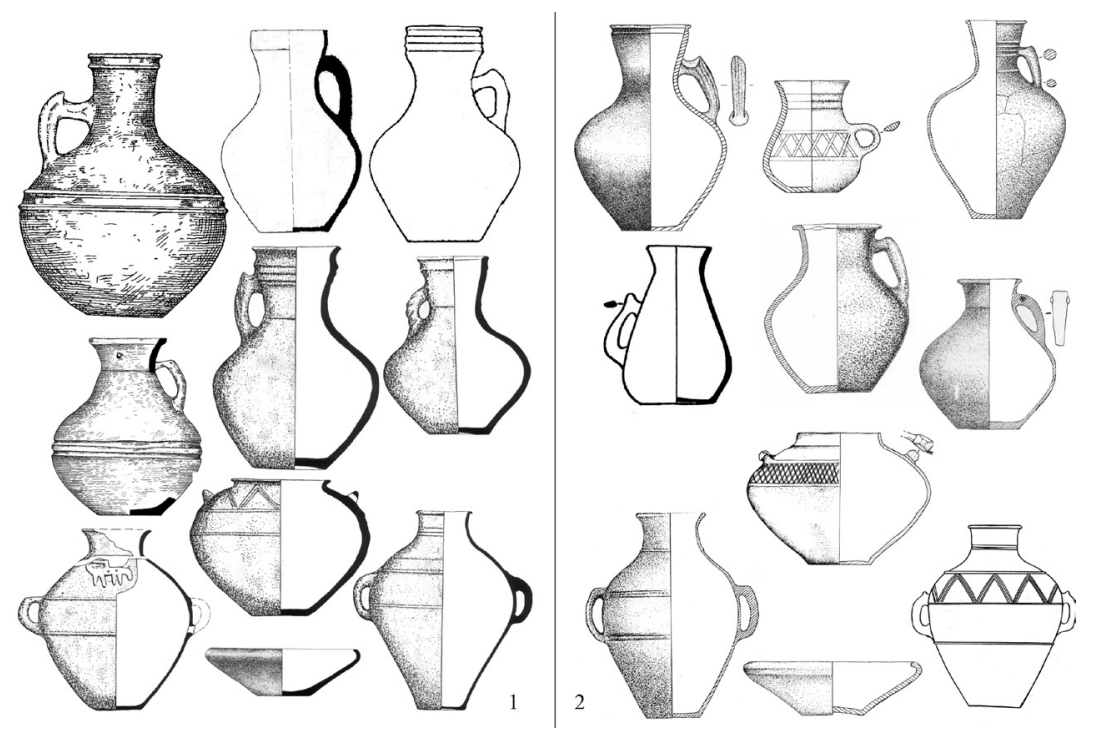

Рис. 1. Керамика северокавказского производства из позднесарматских погребений:

1 - Южное Приуралье; 2 - Волго-Донской регион. 

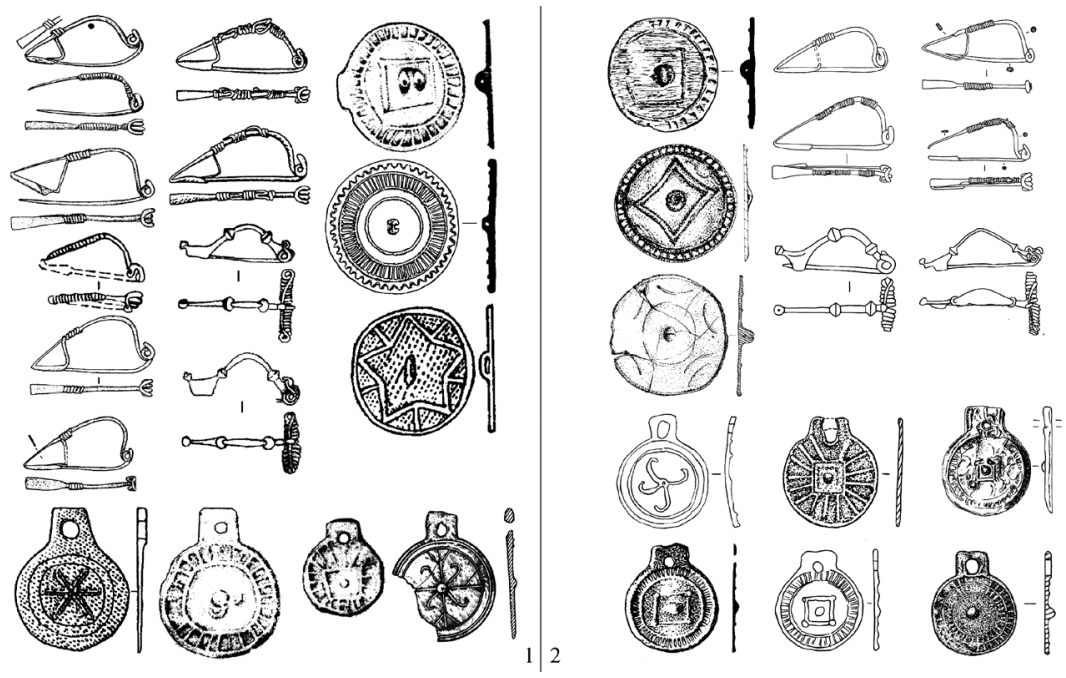

Рис. 2. Фибулы и зеркала-подвески из позднесарматских погребений: 1 - Южное Приуралье; 2 - Волго-Донской регион. 

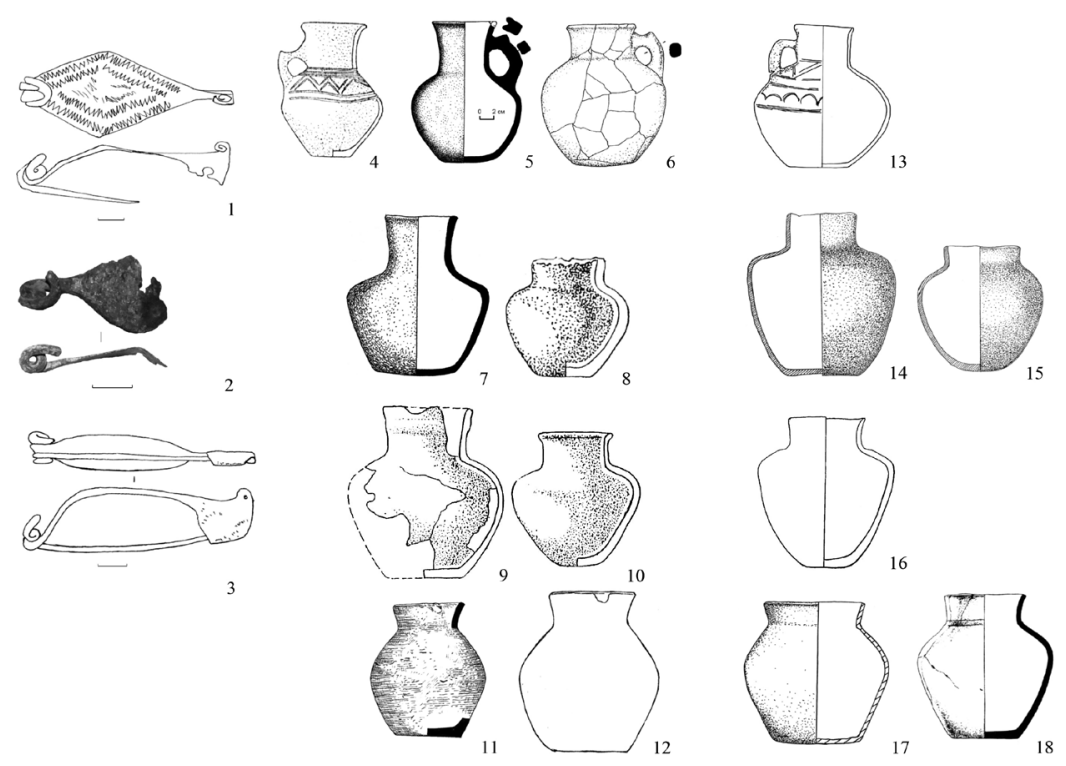

Рис. 3. Фибулы и лепная керамика из позднесарматских погребений Южного Приуралья и Волго-Донского региона. 1-3 фибулы с территории южной части Волго-Донского междуречья; 4-12 - лепная керамика из погребений Южного Приуралья; 1318 - лепная керамика из Волго-Донского региона. 


\section{Я.А. Лукпанова \\ Сакский компонент в культуре ранних кочевников Урало-Илекского бассейна VI-IV вв. до н.э.}

Резюме. В статье рассматриваются элементы погребального обряда саков Приаралья и ранних кочевников Южного Приуралья. Основной целью статьи является выявление трансформации культуры ранних кочевников Урало-Илекского бассейна под воздействием раннесакских компонентов. Понятие «культура ранних кочевников», которое используется в данной статье, подразумевает единство материальной и духовной сфер культуры. Особое внимание уделяется погребальному обряду. Анализируются характер и время изменений местных культурных комплексов под влиянием внешних инноваций. В статье реконструируются процессы проникновения новшеств в материальную и духовную сферы культуры.

Ключевые слова: саки, кочевники, конструкция, ранние кочевники, Приаралье, Приуралье, трансформация.

\section{Ya.A. Lukpanova}

\section{The Saki component in the culture of the early nomads of the Ural-Ilek basin of the $6^{\text {th }}-4^{\text {th }}$ centuries BC.}

Abstract. The article examines the elements of the funeral rite of the Saks of the Aral Sea region and the early nomads of the southern Ural region. The main purpose of the article is to identify 
the transformation of the culture of the early nomads of the Ural-Ilek basin under the influence of the early Saka components. The concept of "culture of early nomads", which is used in this article, implies the unity of the material and spiritual spheres of culture. Special attention is paid to the funeral rite. The nature and timing of changes in local cultural complexes under the influence of external innovations are analyzed. The article reconstructs the processes of penetration of innovations into the material and spiritual spheres of culture.

Key words: Sakas, nomads, construction, early nomads, Priaralye, Urals, transformation.

Южное и Юго-Восточное Приаралье - регион, прилегающий к Аральскому морю, он расположен в дельтовом оазисе нижнего течения рек Сырдарьи и Амударьи, запад этого региона ограничен берегом Аральского моря, юг песками пустыни Кызылкум, на севере его граница идет примерно по современному руслу Сырдарьи ниже города Кызылорда. Регион заполнен огромным количеством «староречий», вся эта система дельтовых протоков функционировала в разные периоды (Итина, 1992, С. 31) и была пригодна для проживания кочевников.

Открытие раннесакских древностей в Южном Приаралье связано с многолетними исследованиями Хорезмской экспедиции Института этнографии АН СССР (Яблонский, 2015, С. 20-24). К могильникам раннесакского времени Приаралья относятся Тагискен, Уйгарак, Сакар-чага (рис.1).

Могильник Уйгарак расположен на границе дельтовой области Сырдарьи и пустыни Кызылкум в юго-западной части Кызылординской области на палеогеновом останце Уйгарак (Толстов, Итина, 1966; Вишневская, 1976). Погребения были выполнены в ямах и на уровне древнего горизонта, причем последние захороне- 
ния составляли наибольшее количество и датировались VI в. до н.э. Могильные ямы большие прямоугольные и узкие. Прямоугольные ямы двух вариантов: а) могилы с округлыми ямками по углам дна, похожие на столбовые, иногда в два ряда; б) могилы с канавкой по периметру дна или только вдоль двух параллельных стенок, образуя подобие земляных «столов» (Вишневская, 1973. С. 60). Узкие ямы были перекрыты хворостом и камышом, лежавшим на основе из жердей. (Вишневская, 1973. С. 61; Итина, 1992. С. 38).

Погребенные головой были ориентированы на запад или юго-запад. Важно отметить, что над погребениями, были зафиксированы остатки сгоревшей погребальной конструкции. В плане эти постройки круглые, овальные, реже - прямоугольные. Очень часто в погребальном обряде прослеживается применение огня, особенно, для погребений на древнем горизонте.

Могильник Тагискен расположен на одноименном плато, в 200 км к западу от Кызылорды. Большинство погребений также как и на Уйгараке совершались на древнем горизонте и в грунтовых ямах, в обряде прослеживается применение огня, сначала сжигалось все, потом сверху насыпался курган.

Погребальные камеры перекрывались деревянными балками, сверху настилали слой камыша или мелкие сучья, также устилали могильный выкид и древнюю дневную поверхность вокруг ямы, затем возводили курган. На Тагискене, как и на Уйгараке были выявлены ямы с канавками, где по периметру стен были выкопаны углубления (Итина, 1992. С. 39). Подавляющее большинство захоронений на могильнике совершены с использованием обряда ингумации.

Погребальные камеры широкой прямоугольной формы с дромосом и без. Дромосные могилы на Тагискене датируются V в. до н. э. и, как правило, представляют собой богатые захоронения (Итина, 1992. С. 39; Байпаков, Таймагамбетов, 2006. С. 170). 
Погребенные в могилах на Тагискене в основном были ориентированы головой на запад, в могилах с дромосом встречаются погребения ориентированные на восток-северо-восток. Скелеты зафиксированы в трех позициях: на спине, на спине с полусогнутой ногой, на спине со сведенными стопами и на спине с раскинутыми в стороны коленями (Итина, Яблонский, 1997. С. 31).

Курганные могильники Сакар-Чага, расположены у северной кромки Заунгузских Каракумов, на территории древней Присарыкамышской дельты Амударьи (Яблонский, 1986. С. 45).

В могильниках Сакар-Чага, как на Уйгараке и Южном Тагискене встречаются два вида погребений, совершенных в ямах и на древнем горизонте, трупосожжение и трупоположение, одиночные и коллективные.

Поверхность бархана выравнивалась, по краю сооружался вал, внутри которого на выровненной площадке была расположена могильная яма с дромосом ориентированной на юг, затем возводилась песчаная насыпь. При совершении кремации, погребенных сжигали внутри площадки, насыпь кургана сооружали над еще непогасшим погребальным костром (Яблонский, 1986. С. 45).

В курганах с трупоположением, часто встречаются разновременные погребения, выполненные на уровне древнего горизонта, большинство из них относятся к раннесакским захоронениям.

Таким образом, элементы погребального обряда ранних саков Приаралья VII-VI вв. до н.э. по материалам исследованных могильников Тагискен, Сакар-Чага, Уйгарак, прослеживаются в погребальном обряде ранних кочевников Южного Приуралья VI-V вв. до н.э. В трудах ряда исследователей были отмечены общие признаки, как в обряде, так и в инвентаре (Смирнов, 1964; Вищневская, Итина, 1971; Яблонский, 1986, Кадьрбаев, 1984. С. 92-93). М.К. Кадырбаев выделял памятники бассейна реки Илек - Бесоба, Сынтас, где явное сходство проявляется в наличии деревянных 
столбовых конструкций, на погребальной площадке и в могилах, в распространении святилищ огня, захоронений на уровне древнего горизонта, в преобладании южной, западной ориентировки умерших в процессе захоронения, а также в использовании настила из камыша, веток и коры, лежащего не только поверх перекрытия, но и на большой площади вокруг ямы, на поверхности вала (Кадьрбаев, 1984. С. 85). Здесь встречаются трупоположение, ингумация, был распространен культ огня. Важно отметить, что курганные комплексы, совершенные с применением огня и со сложными внутри- и надмогильными конструкциями в Приуралье - это усыпальницы, принадлежащие военной аристократии жречеству и племенным вождям кочевников раннего железного века, расселявшимся на этой территории (Смирнов, 1964. С. 88, 89).

За последние 20 лет, на территории Западного Казахстана открыты и исследованы новые памятники археологии, материалы которых расширяют географию памятников, схожих с раннесакскими комплексами Приаралья (Гуцалов, 2007. С. 91). Самыми яркими среди них являются Кырык-Оба-2, Таксай-1, Таксай-3, Жайык -1.

Могильник Кырык-Оба-2 расположен в Бурлинском районе Западно-Казахстанской области в 77 км от Уральска, на левобережье р. Урал. Он состоял из более, чем 30 земляных насыпей, растянувшихся цепочкой с запада на восток. Могильник условно разделен на две части восточную, где насчитывается восемь курганов и западную, образованную из 21 объекта. Под насыпью курганов, были выявлены сложные деревянные конструкции шатрового и срубного типа, опиравшиеся на валы, в центре которых были зафиксированы могильные ямы, выявлены столбовые конструкции. Встречаются захоронения взнузданных коней, уложенных мордой на север, обряд захоронения взнузданных коней под насыпью кургана характерный признак для памятников Южного Приуралья, в курганах Приаралья захоронения коней отсутствуют. 
На могильнике раскопано около 15 объектов. В погребальном обряде практически везде присутствует применение огня. Могильные ямы квадратные, прямоугольные широкие с дромосом, круглые, встречаются коллективные погребения на древней поверхности (курганы № 16, 18) (Гуцалов, 2007. С. 81).

Могила с дромосом была выявлена в кургане № 16 (рис. 2, 1) могильника Кырык-Оба-2. Диаметр кургана 29 м, высота - 1,2 м. Под насыпью в центре кургана была обнаружена могильная яма, прямоугольной формы с округлыми углами, от нее к югу отходил дромос длиной 14 м. Размеры ямы 5,3 х 7,4 м. По периметру кургана на уровне древнего горизонта был обнаружен вал, диаметром 38 м, ширина вала - 4 м. В южной части он был разомкнут. Над могилой был сооружен глиняный склеп. В результате пожарища, разведенного здесь во время погребения, надмогильное сооружение обрушилось. Расположение досок позволяет сделать предположение, что сооружение было шатровым. У входа в склеп обнаружено погребение лошади, головой на север. Могила была ограблена.

Под насыпью кургана № 18 было сооружена могильная конструкция из материкового блока, плотность конструкции примерно 1 м. Склеп окружал кольцевой вал диаметром 21-23 м. Вход был выполнен в юго-западной части. От вала к центру лежали деревянные плахи шириной 20 см. Доски покрыты ветками и слоем камыша и коры. Конструкция представляла собой шатровое сооружение, рухнувшее в результате пожарища, разведенного здесь в процессе захоронения. Погребение было коллективным, выполнено на уровне древнего горизонта, здесь покоилось пять человек. Могила разграблена, только у одного из пяти погребенных кости ног были не потревожены. Судя по их расположению головой они были ориентированы на юг. (Сдъков, Гуцалов, Бисембаев, 2003. С. 59). Аналогичная могила была обнаружена и в кургане 1, могильника Кырык-Оба-2. 
Сопутствующий материал в погребениях данного могильника представлен наборами конской узды, алтариками, бронзовыми котлами, оружием, зеркалами, ритуальными предметами. Многие из них выполнены в зверином стиле. Самыми распространенными изображениями являются образы волка и хищной птицы.

Еще одним типом захоронения, где присутствует столбовая конструкция, является курган № 19. Под насыпью кургана был зафиксирован двухкамерный земляной склеп. Вокруг ямы, на погребенной почве насыпан вал, диаметром 25,5 м. Ширина вала 6 м, высота 0,5 см. От центра сооружения к валу были расположены деревянные доски шириной до 20 см. Плахи были покрыты ветками, тонкими жердями, и поверх всего этого был накрыт слой камыша и коры. За валом доски укладывались прямоугольником, вдоль вала. Это была также конструкция шатрового типа, опиравшаяся на попарно установленные столбы, вокруг могильной ямы. Сооружение было подожжено, бревна обуглились, а вся центральная часть прокалилась до 1 м. Могила была полностью разграблена, в яме был обнаружен железный нож среди костей КРС. В кургане на дневном горизонте было совершено захоронение лошади головой на север.

Могильник Таксай-1,расположен в Теректинском районе, Западно-Казахстанской области. Памятник находится в 50 км от Уральска, близ п. Долинное. Насыпь кургана 6 (рис. 2, 2) округлая, высотой 1 м, диаметром 45 м. В центре кургана, под насыпью, на уровне погребенной почвы была выявлена центральная прямоугольная яма вокруг, которой зафиксированы два кольцевых вала из желтой материковой глины. На уровне погребенной почвы сохранились остатки обгоревшей деревянной надмогильной конструкции. Яма была перекрыта двойным деревянным накатом из тополя, лежавшим на поперечных балках. После снятия верхнего слоя наката, под бревнами была обнаружена прослойка из мелких 
обгоревших веток и речного песка. Диаметр бревен 0,15-0,2 м, глубина ямы - 3,5 м. Дно ямы было застлано мелкими ветками.

С четырех сторон подквадратной ямы - СВ, СЗ, ЮЗ, ЮВ зафиксировано огромное количество шлаков, и следы мощных кострищ. В яме выявлено одно погребение, предположительно женщины, головой ориентированной на запад, с некоторым отклонением на юго-запад. Вещевой комплекс был представлен золотыми нашивными бляшками в зверином стиле, украшениями, подвесками, коробом с ритуальными предметами, зеркалом в ореховом футляре, котлом, жаровней и пятью наборами конской узды. В погребении, как и во всех женских погребениях Приаралья, отсутствовало оружие, также немаловажно отметить, что в могиле было зафиксировано минимальное количество заупокойной пищи, что также характерно для погребений Приаралья (Сдыков, Лукпанова, 2013).

Захоронения воинской элиты, выполненных на уровне древнего горизонта и в грунтовой яме с дромосом были выявлены в курганах 2, 3 могильника Таксай -3. Конструкция кургана 2 (рис. 2, 3) представляла собой кольцевидный глиняный вал, имеющий разрыв с южной стороны. Внутренняя поверхность вала была покрыта корой дерева, а от самого вала к центру кургана радиально были уложены бревна диаметром 0,5-0,8 м верх которых покрыт ветками и корой. Возможно, эта была некогда шатровая конструкция, которая рухнула в результате сожжения. После снятия бревен в юго-западном секторе, внутри вала на 2,75 м к югу от $\mathrm{R}^{0}$ м к западу - 4,60 м на глубине - 0,64 были обнаружены две подпружные бляхи и столбовые ямы. В центре вала была выявлена могильная камера прямоугольной формы, вытянутая длинными сторонами с запада на восток. К югу от нее отходил дромос, который соединялся с ямой 2 (рис. 2, 4). Яму перекрывал бревенчатый накат, который впоследствии был сожжен. 
В кургане было обнаружено захоронение трех воинов, погребенных вероятно, одновременно в центральной яме. Размеры ямы $5 \times 2,65$ м была ориентирована по линии запад - восток и перекрыта двойным бревенчатым накатом. Заполнение ямы представляло собой спрессовавшийся темно-серый гумус с примесью древесного угля, золы. Глубина ямы зафиксирована на уровне - 2,86 м от $\mathrm{R}^{0}$. Стенки ямы прямые, в северо-восточном углу ямы на уровне - 1 м был зафиксирован небольшой уступ. Размеры ямы по дну 4,5 х 2,86 м.

Погребенные были уложены на деревянный настил у северной стенки, его размеры 2,93 х 1,5 м.

Скелет 1 . На бедренной кости левой ноги зафиксирован железный кинжал с сердцевидным перекрестьем, прямым навершием, с левой стороны погребенного на уровне тазовых костей выявлены элементы узды - налобник и распределитель, выполненные в зверином стиле с изображением головы хищной птицы. Вдоль костей правой руки обнаружен воинский жезл или булава (?), состоящий из древка, на которой с двух сторон надевались округлые шаровидные наконечники из бронзы, с V образными сквозными отверстиями. Наконечники с цилиндрической втулкой. У изголовья с правой стороны черепа лежали фрагменты плохо сохранившегося железного псалия. Чуть выше зафиксирован бронзовый двудырчатый псалий с окончаниями голов двух хищных птиц. В 0,1 м правее пяток погребенного зафиксирован чумбурный блок.

Скелет 2. Над черепом была зафиксирована костяная ложка, с навершием на ручке в виде стилизованной морды, оскаленного волка. В 0,1 м западнее ее лежали две бронзовые ворворки.

Скелет 3. На бедренной кости левой ноги выявлен железный кинжал с сердцевидным перекрестьем и прямым навершием. Рядом с кинжалом на уровне перекрестья обнаружено две ворворки. С левой стороны на уровне коленей были выявлены 
три подпружные бляхи с кольцевидным основанием, с грибовидными штырями для крепления фрагмент железного предмета и фрагмент звена удил. С правой стороны черепа были выявлены две пронизи с навершием в виде оскаленного хищника.

В северо-западном углу деревянного настила, над скелетами 2 и 3 был выявлен колчан со стрелами. На бронзовых трехлопастных наконечниках сохранились длинные древки. Среди них найдены два наконечника из кости, пулевидной формы, поверхность их отполирована. Фрагменты черешкового ножа и 2 шила. На одном из них сквозное отверстие. По верхнему краю колчана зафиксированы 18 пронизей с изображением хищников, вероятно, они служили декором кожуха колчана, а также заклепки листовидной формы, функциональная часть их сломана. Рядом с колчаном выявлены спекшиеся фрагменты комплектов удил с псалиями, распределителями ремней, двумя экземплярами чумбурного блока. Рядом выложены 2 бронзовые пронизи с изображением оскаленных кошачьих хищников, конусовидный предмет в виде ворворки из стекла. Под колчаном, в нижней его части, обнаружен умбон из желтого металла.

Под западной стенкой, за пределами деревянного настила были обнаружены пронизь, выполненная в виде кошачьего хищника и навершие в виде лошади с рифлеными рогами.

В южной части ямы были выложены кости лошади. Среди костей были обнаружены три стилизованные обкладки деревянного сосуда в виде клюва птицы и копыта травоядного животного из желтого металла, одна обкладка овальной формы из белого металла и черешковый нож. С внешней стороны деревянного настила, в юго-восточном углу выявлены два распределителя ремней в виде стилизованного скульптурного изображения головы хищной птицы, с загнутым книзу клювом. В 0,4 м к северу от южной стены ямы, рядом с костями лошади 
обнаружены предметы узды, состоящие из налобника и распределителя ремней. Налобник в виде вытянутого клюва хищной птицы с большим глазом выделенным валиком, при развороте фигуры налобник превращается в голову рогатого льва с гривой. Распределитель в виде стилизованного скульптурного изображения ушастой головы хищной птицы.

Дромос неглубокий, длина его - 2,8 м, максимальная глубина - 1,75 м. В северной части дромоса зафиксированы 4 коротких бревна длиной 0,5 м.

Дромос соединялся со второй ямой. Размеры ямы 4,2 х2,8 м на поверхности ямы были зафиксированы бревна уложенные по направлению 3В, в заполнении ямы встречались кости животных, дерево. Стенки ямы не ровные, пологие. В яме было выявлено погребение четырех коней, ориентированных головой на север. Два коня зафиксированы у входа в дромос, кости остальных двух коней были погребены южнее и и были потревожены грабительским вкопом.

В кургане 3, диаметром 45 м, высотой 1,5 м было обнаружено коллективное захоронение на уровне древнего горизонта. Выявлено три скелета, головой ориентированных на юго-восток. Два скелета были погребены вместе, предположительно они принадлежали мужчине и девочке - подростку. Скелет мужчины сильно обгорел, В области шейных позвонков мужчины была выявлена гривна из желтого металла с наконечниками в виде двух кошачьих хищников в прыжке. Возле правой кисти рук обнаружен фрагмент акинака.

Кости полростка потревожены, сохранились лишь тазовые кости и части нижних конечностей. У изголовья его найден лепной плоскодонный сосуд с шаровидным туловом плохой сохранности, зеркало с гладким диском и боковой ручкой на нем бусины, раковина каури, в области тазовых костей обнаружен умбон из желтого 
металла. Ближайшие прямые аналогии гривне и умбону мы находим в Филлипповском могильнике Оренбургской области.

Третий скелет, располагался в 1,5 метрах восточнее от них, кости разбросаны грабителями в древности. Кости человека сохранились фрагментарно в небольшом количестве. Среди инвентаря были обнаружены наконечники стрел, втулка из кости в виде оскаленного насторожившегося волка, лепной горшок с плоским дном, шаровидным туловом и со слегка отогнутым венчиком. Рядом с усопшими были погребены две взнузданные лошади, ориентированные головой на север, их кости также обгорели. Среди костей найдены фрагменты удил и бронзовые пронизи, оформленные в зверином стиле.

При совершении погребального обряда на курганах был применен огонь, шатровые сооружения сгорели, земля прокалилась мощностью до 1,0 м.

Могильник Жайык-1 расположен на правом высоком берегу р. Урал, в 13 км юго-западнее г. Уральск, при въезде на территорию средневекового городища Жайык. Курган 1, являлся самым большим, его диаметр - 42 м, высота - 1,8 м (рис. 3,1 ). Он сооружался в два этапа, имел сложную подкурганную конструкцию (рис. 3, 2). Период раннего сооружения кургана относится к V-IV вв. до н.э., позже курган неоднократно досыпался и дополнялся более поздними впускными захоронениями. Центральная часть кургана была сложена из грунтовых блоков, вырезанные из верхнего гумусового горизонта, они были уложены на бревна, которые впоследствии сгорели во время сжигания конструкции. Размер блоков примерно $30 \times 20 \times 15$ см. По периферии внутренняя насыпь окружена кольцевым рвом глубиною от 0,5 до 2,5 м, ширина рва варьировалась от 0,5 до 1,5 м. Важно отметить, что с северной стороны ров был более глубоким и ширина максимальной, вход зафиксирован с южной 
стороны. В заполнении кольцевого рва на разных глубинах обнаружены камни, мел, кости животных, фрагменты керамики, фрагменты жертвенников разных форм.

В центральной части кургана присутствуют следы горения в виде обожженных и оплавленных блоков, шлаков, кусков грунта кирпичного и темно-розового цветов, обугленные фрагменты древесины. Сложенная из блоков внутренняя конструкция перекрыта насыпью из желто-серого рыхлого гумусированного суглинка, представляющего собой слой грунта, залегающего под гумусовым горизонтом на участках заготовки строительных блоков. К сожалению, погребение ограблено в древности.

Таким образом, рассмотрев материалы из комплексов Уйгарак, Южный Тагискен, Сакар-Чага мы в полной мере можем допустить, что в VI-V вв. до н.э. сакские культурные параллели проявляются в погребальном обряде племен савроматской культуры Южного Приуралья. Они сказываются на конструкции, инвентаре, ориентировке погребенных и обряде в целом.

Сакские племена, которые оставили свои памятники в Приаралье датируемые VII-V вв. до н. э., генетически свое начало берут с эпохи поздней бронзы (Вишневская, 1973. С. 60-69, 127-128; Толстов, Итина, 1966. С. 152-157; Вишневская, Итина, 1971. С. 197-199; Итина, Яблонский, 1997. С. 28-37, 80; Кадырбаев, 1984. С. 92, Бейсенов, 2016. С. 88 и др.).

Погребения на древнем горизонте, которые выявлены в значительной степени в могильниках, аналогичны по планировке могильным конструкциям погребальных сооружениий эпохи поздней бронзы Северного Тагискена (Вишневская, 1973. С. 128). Это дополняется обрядом трупосожжения и западной ориентировкой погребенных, канавками вдоль стен могил. С эпохи бронзы берут свое начало и дромосные захоронения, которые были распространены и у саков Южного Приаралья. 
Безусловно, в погребальном обряде ранних кочевников Южного Приуралья VI-V вв до н.э. присутствует сакский компонент. Наличие погребений выполненных на древнем горизонте с надмогильными сооружениями, прямоугольные ямы с перекрытием из жердей, травы и камыша и покрытие древней дневной поверхности вокруг ямы. Истоки обряда погребения на поверхности горизонта, по мнению исследователей, следует искать, возможно, в степных могильниках эпохи поздней бронзы, где такие захоронения встречались. Имели место активные контакты между населением двух регионов в эпоху бронзы. Это выражалось в форме «притока населения с северо-запада на юго-восток» (Вuшневская, Итина, 1971. С. 207), имела место «взаимная прямая инфильтрация населения», где отдельные племена входили в состав друг друга (Смирнов, 1964. С. 277-280), что сказалось на погребальном обряде и инвентаре ранних кочевников Приуралья.

У саков Приаралья и ранних кочевников Приуралья зафиксированы различные формы использования огня в погребальном обряде, имеет место и трупосожжение. В курганах могильников Кырык-оба-2, Таксай-1, 3, Жайык-1 были зафиксированы сожжения перекрытия могил, что сближает их с погребениями Уйгарака, Южного Тагискена, Сакар-Чаги.

Важно отметить и вопрос появления дромосных захоронений в Приуралье датируемыми концом VI-V в. до н.э. Вероятно, данный вид погребальной конструкции появился в регионе с приходом элитных групп кочевых объединений племен с юга, юго-востока Казахстана (Таиров, Гаврилюк, 1988. С. 144-145; Исмагилов, 1996. С. 44; Сиротин, 2013. С. 13-25) и в этом большую роль сыграли саки Приаралья. В Южном Приуралье они появляются в VI в. до н.э, тогда как в сакских памятниках Северного, Восточного, Юго-Восточного Казахстана, Южного Приаралья появились не позднее VIII-VII вв. до н.э. и истоки подобных кон- 
струкций начинаются с эпохи поздней бронзы (Бейсенов, 2016. С. 87). А.Д. Таиров, отмечает, что подобное влияние произошло в результате миграции части сакских племен в Южное Приуралье, в результате активной завоевательной политики ахеменидской Персии в конце VI в. до н.э в этом регионе (Таиров, 2006. С. 76).

Подтверждением культурно-генетической преемственности населения двух областей является проявление в Южном Приуралье во второй половине VI - начале V вв. до н.э. сакского компонента в погребальном обряде, инвентаре.

В памятниках Западного Казахстана встречаются предметы импорта, изготовленные в Средней Азии и Ахеменидском Иране возможно, в этом немалую роль сыграли саки Приаралья, которые имели обширный круг этнических и культурных связей.

В курганах со сложной конструкцией, со специфическим погребальным обрядом была погребена кочевая элита. По предположению С.Ю. Гуцалова в регион переселилась большая группа кочевников Приаралья, вследствие войн Кира II и Дария I с саками, под их влиянием потом сложилась культура ранних кочевников (Гуиалов, 2007. С. 91). Возможно, в Приуралье мигрировала определенная часть элиты саков Приаралья, ассимилировалась и принесла свои элементы культуры, что сказалось и на на обряде захоронения ранних кочевников Южного Приуралья.

\section{ЛИТЕРАТУРА}

Байпаков К.М., Таймагамбетов Ж.К., 2006. Археология Казахстана: учебное пособие для студентов высших учебных заведений. Алматы: Қазақ университеті. 356 с.

Бейсенов А.З., 2016. Дромосные курганы сакской эпохи урочища Назар (Центральный Казахстан) // Самарский научный вестник. № 1 (14) 87. С. 84-93 
Вишневская О.А., 1973. Культура сакских племен низовьев Сыр-Дарьи в VII-V вв. до н.э. (по материалам Уйгарака) // ТХАЭЭ. Т. VIII. М.: Наука. 160 с.

Вишневская О.А., Итина М.А., 1971. Ранние саки Приаралья // Проблемы скифской археологии. МИА, № 177. М. С. 197-208.

Гуиалов С.Ю., 2007. Погребальные памятники кочевой элиты Южного Приуралья середины I тыс. до н.э. // Археология, этнография и антропология Евразии. № 2 (30). С. 75-92.

Гуиалов С.Ю., Бисембаев А.А., Сдьков М.Н., 2007. Скифы Западного Казахстана. Алматы: Исламнұр, 208 с.

Исмагилов Р.Б., 1996. Сарматское окно в Европу // Актуальные проблемы древней истории и археологии Южного Урала // ред. Н. А. Мажитов, М. Ф. Обыденнов. Уфа: Изд-во «Восточный университет». Уфа. С. 32-71.

Итина М.А., 1992. Ранние саки Приаралья // Археология СССР. Степная полоса Азиатской части СССР в скифо-сарматское время. М.: Наука. С. 31-47.

Итина М.А., Яблонский Л.Т., 1997. Саки Нижней Сырдарьи (по материалам могильника Тагискен). М.: Российская политическая энциклопедия (РОССПЭН). 187 с.

Кадырбаев М.К., 1984. Курганные некрополи верховьев р. Илек // Древности Евразии в скифо-сарматское время. М.: Наука. С. 84-93.

Сдыков М.Н., Гуизалов С.Ю., Бисембаев А.А., 2003. Сокровища скифов Западного Казахстана. Уральск. 124 с.

Сдъков М.Н., Лукпанова Я.А., 2013. Ранние кочевники Западного Казахстана (на примере курганного комплекса Таксай-1). Уральск: Полиграфсервис. 292 с.

Сиротин С.В., 2013. Погребальный комплекс дромосного типа эпохи ранних кочевников из юго-восточной Башкирии // Вестник Башкирского университета. Т. 18, № 4. С.1323-1327. 
Смирнов К.Ф., 1961. Археологические данные о древних всадниках поволжско-уральских степей // СА. №1. С. 46-72.

Смирнов К.Ф., 1964.Савроматы: Ранняя история и культура сармат. - М.: Наука. 380 с.

Таиров А.Д., Гаврилюк А.Г., 1988. К вопросу о формировании раннесарматской (прохоровской) культуры // Проблемы археологии Урало-Казахстанских степей / Ред. Г.Б. Зданович. Челябинск: Изд-е Башкирского ун-та. С. 141-159.

Таиров А.Д., 2006. Саки Приуралья в степях Южного Зауралья (по материалам могильника Маровый Шлях) // Южный Урал и сопредельные территории в скифо-сарматское время: Сборник статей к 70-летию Анатолия Харитоновича Пшеничнюка // Отв. ред. Г. Т. Обыденнова, Н. С. Савельев. Уфа: Гилем. С.76-91

Толстов С.П., Итина М.А., 1966. Саки низовьев Сыр-Дарьи (по материалам Тагискена) // СА. № 2. С. 151-175.

Яблонский Л.Т., 1996. Саки Южного Приаралья: (археология и антропология могильников). М.: ИА РАН. 185 с

Яблонский Л.Т., 1986. К этногенезу населения северной Туркмении (могильник раннесакского времени Сакар-чага 3) // СЭ. № 5. С. 45-54.

Яблонский Л.Т., 2015. Саки в дельте Окса. М.: Новое время. 312 c.

\section{СВЕДЕНИЯ ОБ АВТОРЕ.}

Лукпанова Яна Амангельдиевна, Западно-Казахстанский центр истории и археологии, Уральск, Казахстан, e-mail: Yana_2004_75@mail.ru 


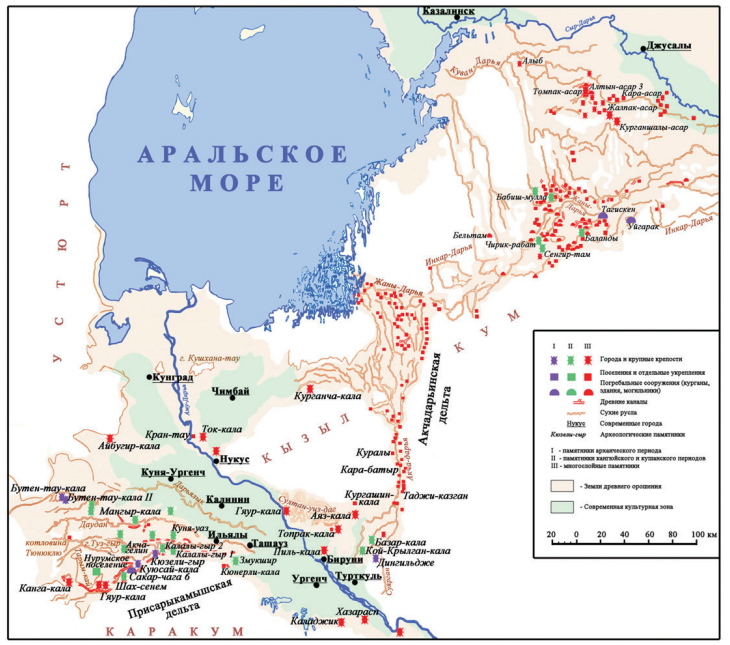

Карта археологических памятников Хорезма и низовий Сырдарьи по С.П. Толстому, 1948

Рис. 1. Карта археологических памятников Хорезма и Низовий Сырдарьи. 


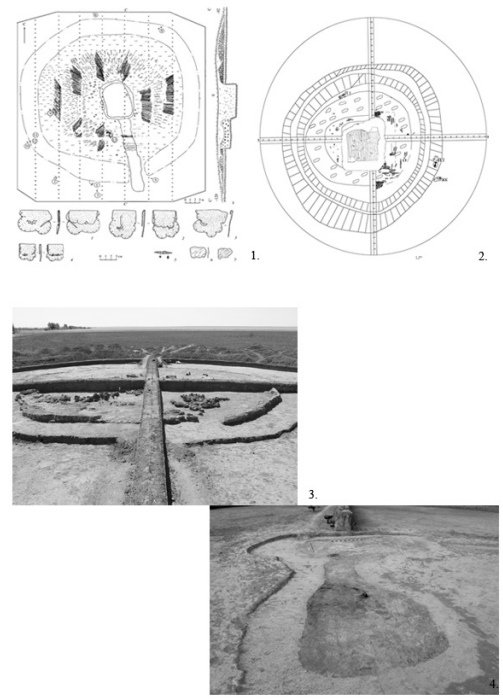

Рис. 2. Комплексы из могильников Кырык-Оба-2, Таксай-1, Таксай-3: 1 - план кургана 16 могильника Кырык-Оба-2 (по С.Ю. Гуцалову); 2 - план кургана 6 могильника Таксай-1; 3 - вид на курган 2 могильника Таксай-3 в процессе раскопок; 4 - могильная яма с дромосом в кургане 2 могильника Таксай-3.
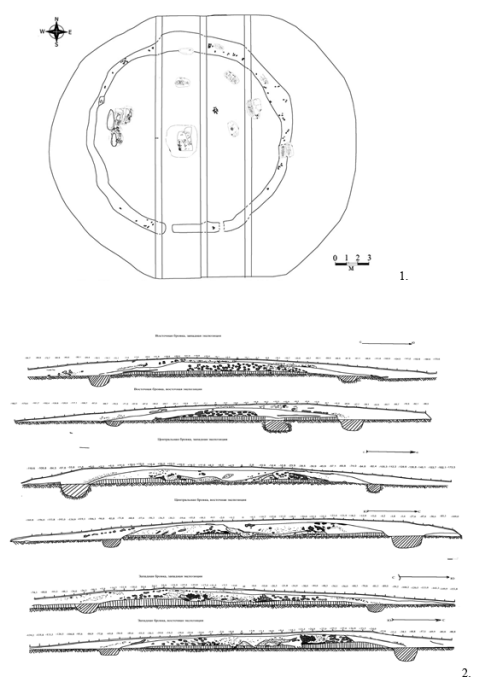

Рис. 3. План и профили кургана 1 могильника Жайык-1. 1 - план кургана 1 могильника Жайык-1; 2 - профили кургана 1 могильника Жайык-1. 


\section{Е.В. Лылова}

\section{К вопросу о датировке спиралевидных височных подвесок из погребений ранних кочевников Южного Урала}

Резюме. В данной работе рассматривается первый тип височных колец, выделенный М.Г. Мошковой - височные кольца или серьги в виде кольца с заходящими друг за друга концами или спирали в 1,5-2 оборота. М.Г. Мошковой в 1963 г. была разработана первая классификация сарматских украшений, которая учитывая форму и технику изготовления, выделила несколько типов гривен, браслетов, сережек (височных колец), бусин и бляшек из могил прохоровского времени. Исследователем на базе, в которую входило 22 украшения, происходящих из 17 комплексов с территории Южного Приуралья и Нижнего Поволжья, был сделан вывод о существовании определенной зависимости между диаметром колец и временем их существования.

Тезис был проверен в рамках настоящего исследования на материалах в виде 128 украшений из 83 комплексов Южного Урала путем хронологической корреляции их диаметров.

В результате сделан вывод о том, что для памятников IV в. до н.э. характерны височные кольца диаметром более 25 мм. Диаметр височных колец с IV-III вв. до н.э. не превышает 24 мм. На материалах прослеживается тенденция уменьшения диаметра височных колец от IV ко II-I вв. до н.э. Уменьшение диаметров меньше 20 мм происходит на рубеже IV-III вв. до н.э.

Таким образом, рассматриваемый тезис М.Г. Мошковой в целом подтверждается современными материалами, работает и 
справедливо используется современными исследователями при датировке памятников.

Ключевые слова: Южный Урал, ранние кочевники, украшения, тип, височные подвески, височные кольца, серьги.

\section{E.V. Lylova}

\section{On the dating of spiral temporal pendants from the burials of early nomads of the Southern Urals}

Abstract. This work reviews the first type of temple rings, designated by Moshkova - temple rings or ear-rings in the shape of the ring with the crossing edges, or in the shape of 1,5-2 turns spiral. In 1963 M. Moshkova had developed first regimentation of Sarmat decorations, that included several types of hrivnyas, wristbands, earrings (temple rings), beads and badges from Prokhorov mounds. The researcher, based on the study of 22 decorations from 17 complexes of Southern Urals and Lower Volga regions, makes a conclusion on certain dependence between diameter of the rings and their time.

This thesis had been checked within the present research with the materials of 128 decorations from 83 complexes of the Southern Urals by the chronology correlation of their diameters.

In result the following conclusion had been made: temple rings over $25 \mathrm{~mm}$ in diameter are the feature of IV century BC. The diameter of the temple rings in IV-II century BC never exceeds $24 \mathrm{~mm}$. Based on the materials, a tendency of temple rings diameter decrease from IV to II-I centuries BC, can be traced. The decrease of the diameters below $20 \mathrm{~mm}$ occurs in the edge of IV-III centuries BC.

This way the reviewed thesis, made by Moshkova works and is a right tool for modern researchers for artifacts dating. 
Key words: Southern Urals, early nomads, decorations, type, temple pendants, temple rings, ear-rings.

Ювелирные украшения, в первую очередь те из них, что входили в состав костюма, по всей видимости, имели достаточно короткую жизнь, так как, являясь частью личного убранства, оказывались погребенными вместе со своим хозяином. С этой точки зрения они представляют интерес в части возможности использования их в качестве датирующих предметов.

Некоторые категории украшений уже рассматривались в литературе в качестве датирующих. Так, В.М. Клепиковым убедительно доказано существование железных стержневых браслетов с заходящими друг на друга концами из раннесарматских памятников в рамках IV в. до н.э. (Клепиков, 2002. С. 83-88). Данный вывод был принят научным сообществом и довольно активно используется исследователями при определении датировки комплексов.

На датирующие возможности спиралевидных височных подвесок впервые обратила внимание М.Г. Мошкова. Ею была разработана первая классификация сарматских украшений, в рамках которой учитывалась форма изделия и техника его изготовления. М.Г. Мошкова выделила несколько типов гривен, браслетов, сережек (височных колец), бусин и бляшек из комплексов прохоровского времени (Мошкова, 1963. С. 43-45).

В распоряжении исследователя находился сравнительно небольшой материал - изображения всех металлических украшений помещались в одной таблице (Мошкова, 1963. Табл. 29).

Мариной Глебовной был сделан вывод о том, что наиболее распространенными и характерными украшениями населения прохоровского времени были серьги или височные кольца, представленные в могилах тремя типами: 1) височные кольца 
или серьги в виде кольца с заходящими друг за друга концами или спирали в 1,5-2 оборота (Мошкова, 1963. Табл. 29. Рис. 1-4, 7, 12-28); 2) спиральные кольца с припаянными украшениями (Мошкова, 1963. Табл. 29. Рис. 6, 29, 31, 33, 35); 3) спиральные кольца с петельками с прикрепленными сдвоенными полулунными щитками (Мошкова, 1963. Табл. 29. Рис. 30).

Необходимо отметить, что данная классификация не только послужила основой для последующих построений ученых, но и сохранила самостоятельное значение, не смотря на существенное расширение источниковой базы.

В данной работе рассматривается 1-й тип сережек или височных подвесок, выделенный М.Г. Мошковой.

Характеризуя данный тип украшений, Марина Глебовна пишет: «Самой ранней и распространенной формой являются бронзовые, золотые, серебряные, или бронзовые, обложенные золотом, височные кольца или серьги в виде кольца с чуть заходящими друг за друга концами или спирали в 1,5-2 оборота. Концы колец бывают тупые, чаще чуть заостренные, в редких случаях даже утолщенные. Независимо от материала, сечение проволоки, из которой делались кольца, всегда круглое. Кольца эти известны начиная с IV в. до н.э., вплоть до III-II вв. до н.э., причем наиболее ранние IV в до н.э. сравнительно большие - диаметром 1,9-3,4 см, а с конца IV-III вв. до н.э. диаметр височных колец-сережек не превышает 2 см, обычно же 1-1,5 см» (Мошкова, 1963. С. 44. Табл. 29, 1-4, 7, 12-28).

Таким образом, данный вывод был сделан М.Г. Мошковой на 22 украшениях из 17 комплексов (Мошкова, 1963. Табл. $29,1-4,7,12-28)$. Для наглядности он проиллюстрирован в настоящей работе в виде графика, демонстрирующего хронологическую корреляцию диаметров височных подвесок 1-го типа из комплексов ранних кочевников Нижнего Поволжья и Южного 
Урала (рис.1, 1). На данном графике мы видим группу украшений диаметром 20-30 мм IV в. до н.э., которые не встречаются в более поздний период. Другая группа объединяет украшения III-II вв. до н.э., II-I вв. до н.э. диаметры которых составляют 10-16 мм.

Данный тезис был поддержан наблюдениями А.Х. Пшеничнюка, который отмечает, что височные кольца «...из позднепрохоровских погребений (Старые Киишки, Бишунгарово, Боголюбовка) небольших размеров, диаметром 1-1,5 см. Кольца из ранних могил крупнее, диаметры их от 2,5 до 3,6 см...» (Пшеничнюк, 1983. С. 112).

B.М. Клепиков соглашается с выводом о том, что «...крупные подвески 3-4 см диаметром действительно прекращают бытование с рубежа IV-III вв. до н.э.», однако считает, что «...маленькие имеют более широкие хронологические рамки. Они изредко встречаются с савроматского времени синхронно с крупными, но затем полностью сменяют их и сохраняются в погребальном инвентаре вплоть до I-II вв. н.э.» (Клепиков, 2002. С.89). Случаи нахождения украшений данного типа в погребениях савроматского времени, также как и сочетания в одном комплексе крупных и мелких подвесок с территории Южного Урала мне не известны.

Целью моей работы ставилось проверить вывод М.Г. Мошковой о корреляции диаметра височных подвесок со временем их бытования на современном материале с территории Южного Урала. Внимание к этому моменту объясняется активным использованием данного тезиса исследователями его для датировки памятников (например, Матюшко И.В. и др., 2016. С. 114).

Для проверки этого тезиса на более широкой источниковой базе мною были собраны материалы (с учетом материалов, использованных М.Г.Мошковой в 1963 г.), куда вошли 128 украшений из 83 комплексов с территории Южного Урала (рис. 2-5, таб. 1). Далее была произведена хронологическая корреляция диаметров височных подвесок (сережек) 1-го типа из этих комплексов (рис. 1, 2). 
В группу украшений IV в. до н.э. (рис. 2) входит 32 экземпляра из 21 комплекса. Из этих украшений 22 составляли пары (11 пар), 10 расположены возле погребенного по одному. Диаметры колец варьируют от 25 до 43 мм.

Группа украшений IV-III вв. до н.э. (рис. 3) состоит из 20 экземпляров, которые происходят из 12 комплексов. Из них 16 составляли пары (8 пар), 4 расположены возле погребенного по одному. Диаметры колец варьируют от 11 до 24 мм.

Причем диаметры более 20 мм для этой группы не характерны. Пара височных колец из погребения 4 кургана 6 могильника Мечет-Сай диаметром 24 мм и одно височное кольцо из погребения 2 кургана 9 могильника Лебедевка VII диаметром 21 мм выделяются из всей группы украшений IV-III вв. до н.э. своими относительно крупными размерами. Остальные 17 экземпляров имеют диаметры 11-15 мм.

Группа украшений III-II вв. до н.э. (рис. 4) представлена 73 экземплярами из 50 комплексов. Из них 44 составляли пары (22 пары), 29 зафиксированы возле костяка по одному. Их диаметры варьируют от 9 до 20 мм.

Группа украшений II-I вв. до н.э. (рис. 5) представлена 3 экземплярами, происходящими из 2 комплексов (2 из них образовывали пару, 1 - непарное). Диаметры колец варьируют от 8 до 15 мм.

Анализ представленных материалов позволяет сделать следующие выводы. Спиралевидные височные подвески (серьги) характерны для кочевнических погребений степной зоны Южного Урала на всем протяжении развития раннесарматской культуры. При этом форма остается постоянной - число витков варьирует от незначительного захождения концов друг за друга до 2 неполных оборотов (рис. 2-5). Чаще всего их находят в районе черепов погребенных - как парами, по обе стороны черепа, так и по одному - справа, либо слева от черепа. 
Видимо, такое расположение украшений в погребениях соответствовало способу их ношения при жизни. Размеры же подвесок (сережек) с течением времени изменяются в сторону уменьшения диаметров. Для памятников IV в. до н.э. характерны височные кольца диаметром 25 мм и более. Диаметр височных колец с IV-III вв. до н.э. не превышает 24 мм, чаще же всего этот диаметр составляет 20 мм и менее. Прослеживается тенденция уменьшения диаметра височных колец от IV в. до н.э. ко II-I вв. до н.э. Уменьшение диаметров меньше 20 мм происходит на рубеже IV-III вв. до н.э.

Таким образом, рассматриваемый тезис М.Г. Мошковой в целом подтверждается современными материалами, работает и справедливо используется современными исследователями при датировке памятников.

\section{ЛИТЕРАТУРА}

Агеев Б.Б., Рутmо Н.Г., 1984. Новые памятники прохоровской культуры на юге Башкирии // Памятники кочевников Южного Урала / Отв. ред. В.А. Иванов. Уфа: БФАН СССР. С. 37-45.

Бытковский О.Ф., 1998. Отчет о работе Орской археологической экспедиции в 1998 году // Архив ИА РАН, 1-Р, №22109.

Веддер Дж., Егоров В.Л., Дэвис-Кимболл Дж., Моргунова Н.Л., Трунаева Т.Н., Яблонский Л.Т., 1993. Раскопки могильников Покровка 2 и Покровка 8 в 1992 г. // Курганы левобережного Илека. Вып. 1. / Ред. Л.Т. Яблонский. М.: ИА РАН. С. 18-55.

Воронова С.А., Порохова О.И., 1992. Чкаловский курганный могильник // Древняя история населения Волго-Уральских степей / Отв. ред. А.Т. Синюк. Оренбург: Оренбургский пединститут им. В. Чкалова. С. 228-255.

Гуиалов С.Ю., 1985. Отчет об археологических разведках и 
раскопках в Актюбинской области летом 1985 г. Личный архив С.Ю. Гуцалова.

Гуцалов С.Ю., 1991. Отчет об археологических работах в Актюбинской области летом 1991 г. Личный архив С.Ю. Гуцалова.

Гуцзалов С.Ю. Родионова В.В., 1984. Отчет об археологических раскопках в Актюбинской области в 1984 г. Личный архив С.Ю. Гуцалова.

Железчиков Б.Ф., Кригер В.А., 1978 г. Катакомбные захоронения Уральской области // СА. №4. С.219-229.

Железчиков Б.Ф., 1998. Археологические памятники Уральской области. Волгоград: Издательство Волгоградского государственного университета. $136 \mathrm{c.}$

Железчиков Б.Ф., Клепиков В.М., Сергачков И.В., 2006. Древности Лебедевки (VI-II вв. до н.э.). М.: Вост. лит. 159 с.

Заседателева С.Н., 1984. Отчёт о работе археологической экспедиции краеведческого музея в 1984 г. Архив Орского краеведческого музея.

Заседателева С.Н., 1985. Отчёт о работе археологической экспедиции краеведческого музея в 1985 г. Архив Орского краеведческого музея.

Заседателева С.Н., 1989. Отчет о работе Орской археологической экспедиции в 1989 г. // Архив ИА РАН, Р-1, №14220, 14221.

Клепиков B.M., 2002. Сарматы Нижнего Поволжья в IVIII вв. до н.э. Волгоград: Издательство Волгоградского государственного университета. 216 с.

Матюшко И.В., Моргунова Н.Л., Туреикий М.А., Файзуллин A.A., 2016. Курганный могильник у с. Донецкое // Археологические памятники Оренбуржья. Вып. 12. С. 102-115.

Мещеряков Д.В., 1997. Впускные погребения сарматской культуры в курганах на р. Илек // Археологические памятники Оренбуржья. Вып.1. С. 44-67. 
Моргунова Н.Л., Мещеряков Д.В., 1999. «Прохоровские» погребения V Бердянского могильника // Археологические памятники Оренбуржья. Вып. III. С. 124-146.

Моргунова Н.Л., Гольева А.А., Краева Л.А., Мещеряков Д.В., Турецкий М.А., Халяпин М.В., Хохлова О.С., 2003. Шумаевские курганы. Оренбург: Издательство ОГПУ. 392 с.

Моргунова Н.Л., Евгенвев А.А., Крюкова Е.А., Купцова Л.В., Харламов П.В., Файзуллин И.А., 2016. Переволоцкий курганный могильник в Оренбургской области: предварительные результаты исследования // Археологические памятники Оренбуржья. Вып. 12. С. 21-51.

Малашев В.Ю., 2002. Отчет Илекской экспедиции ИА РАН о раскопках могильника Покровка 10 в Соль-Илецком районе Оренбургской области в 2001 г. // Архив ИА РАН.

Мошкова М.Г., 1963. Памятники прохоровской культуры (САИ, Д 1-10) / Ред. Б.А. Рыбаков. М.: Издательство АН СССР. 56 с.

Мошкова М.Г., 1969. Отчет о работе Западно-Казахстанской экспедиции 1969 г. // Архив ИА РАН, Р-1, № 4381, 4381a.

Мошкова М.Г., Кушаев Г.В, 1973. Сарматские памятники Западного Казахстана // Проблемы археологии Урала и Сибири / Отв. ред. А.П. Смирнов. М.: Наука. С. 258-268.

Пшеничнюк А.Х., 1983. Культура ранних кочевников Южного Урала. М.: Наука. 200 с.

Родионов В.В., Гуцалов С.Ю., 2000. Материалы погребений и случайных находок савромато-сарматского времени из фондов Актюбинского краеведческого музея // Уфимский археологический вестник. Выпуск 2. С. 129-144.

Садыкова М.X., 1958. Научный отчет за 1958 г. «Сарматские памятники на территории Кармаскалинского и Федоровского районов» // Архив ИА РАН № 1902, 1902 а. 
Садыкова M.X, 1962. Сарматский курганный могильник у дер. Старые Киишки // Археология и этнография Башкирии. Том 1. Уфа: БФАН СССР. С. 88-122.

Садькова М.Х., Васильев В.Н., 2001. Поздние прохоровцы в центральной Башкирии // Уфимский археологический вестник. Вып. 3. С. 55-80.

Смирнов К.Ф., 1957. Отчет о работе Чкаловской экспедиции ИИМК 1957 г. // Архив ИА РАН, Р-1, №1686, 1686а.

Смирнов К.Ф., 1961. Отчет о работе Оренбургской экспедиции института археологии АН СССР и Оренбургского музея краеведения 1961 г. // Архив ИА РАН, р-1, №2499, 2499а.

Смирнов К.Ф., 1964. Савроматы. Ранняя история и культура сарматов. М.: Наука. 380 с.

Смирнов К.Ф., 1971. Отчет Оренбургской экспедиции института археологии АН СССР и Оренбургского краеведческого музея в 1971 г. // Архив ИА РАН, Р-1, №4510, 4510а.

Смирнов К.Ф, 1972. Отчет о работе Оренбургской археологической экспедиции 1972 г. // Архив ИА РАН, Р-1, №4814, 4814a.

Смирнов К.Ф., 1975. Сарматы на Илеке. М.: Наука. 176 с.

Яблонский Л.Т., Трунаева Т.Н., Веддер Дж, Дэвис-Кимболл Дж., Егоров В.Л, 1994. Раскопки курганных могильников Покровка 1 и Покровка 2 в 1993г. // Курганы левобережного Илека / Ред. Л.Т. Яблонский. Вып.2. М.: ИА РАН. С. 4-60.

Яблонский Л.Т., Дэвис-Кимболл Дж., Демиденко Ю.В, 1995. Раскопки курганных могильников Покровка 1 и Покровка 2 в 1994 г. // Курганы левобережного Илека / Ред. Л.Т. Яблонский. Вып. 3. М.: ИА РАН. С. 9-47.

Яблонский Л.Т., Дэвис-Кимболл Дж., Демиденко Ю.В., Малашев В.Ю., 1996. Раскопки могильников Покровка 1, 2, 7 и 10 в 1995 году. // Курганы левобережного Илека / Ред. Л.Т. Яблонский. Вып. 4. М.: ИА РАН. С. 7-48. 
Яблонский Л.Т., 2003. Отчет об исследовании курганного могильника Прохоровка-I в Шарлыкском районе Оренбургской области РФ в 2003 году // Архив ИА РАН.

\section{СВЕДЕНИЯ ОБ АВТОРЕ.}

Лылова Евгения Владимировна, ООО «НПП Археобюро», г. Оренбург, Россия, e-mail: amaga-4@yandex.ru. 

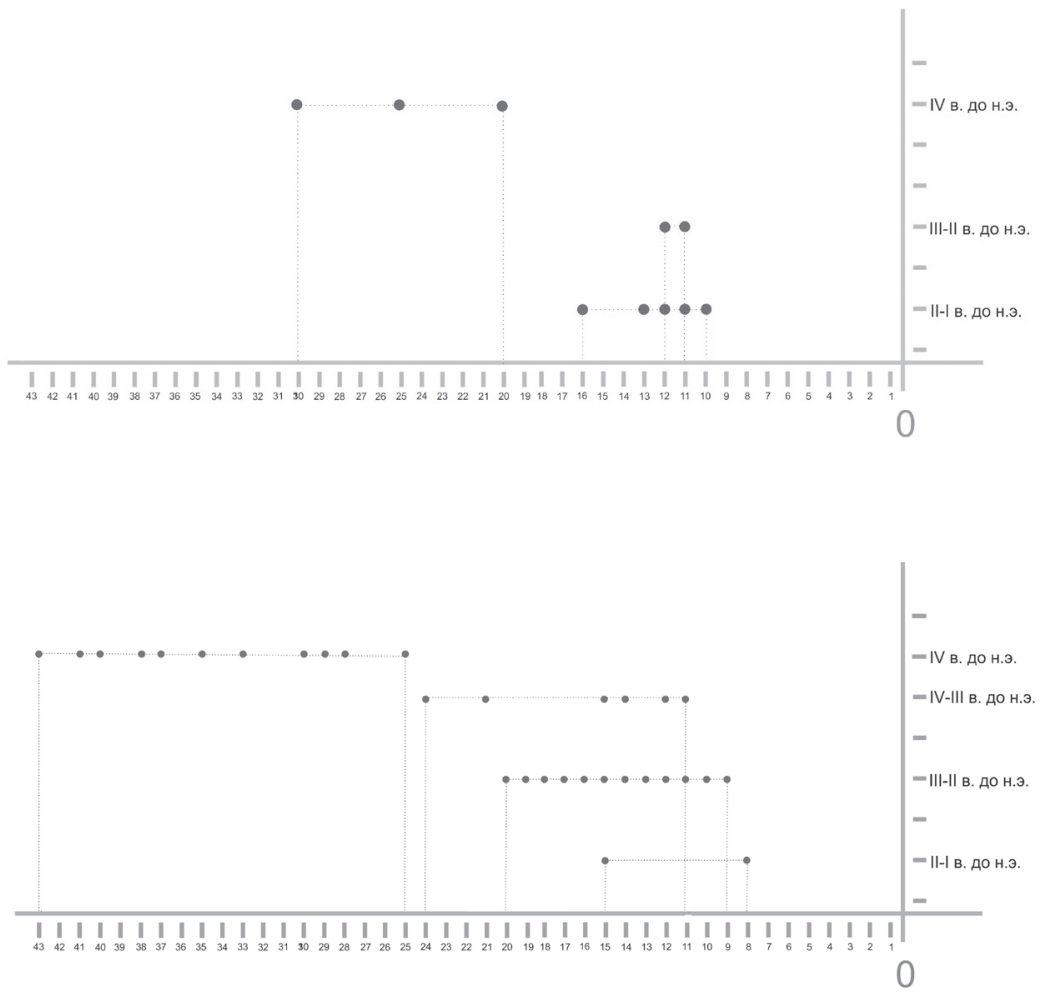

Рис. 1. Хронологическая корреляция диаметров височных подвесок 1-го типа по М.Г. Мошковой: 1 - височные подвески из комплексов ранних кочевников Южного Урала и Нижнего Поволжья (1963 год); 2 - височные подвески из комплексов ранних кочевников Южного Урала (с 1963 года по настоящее время). 

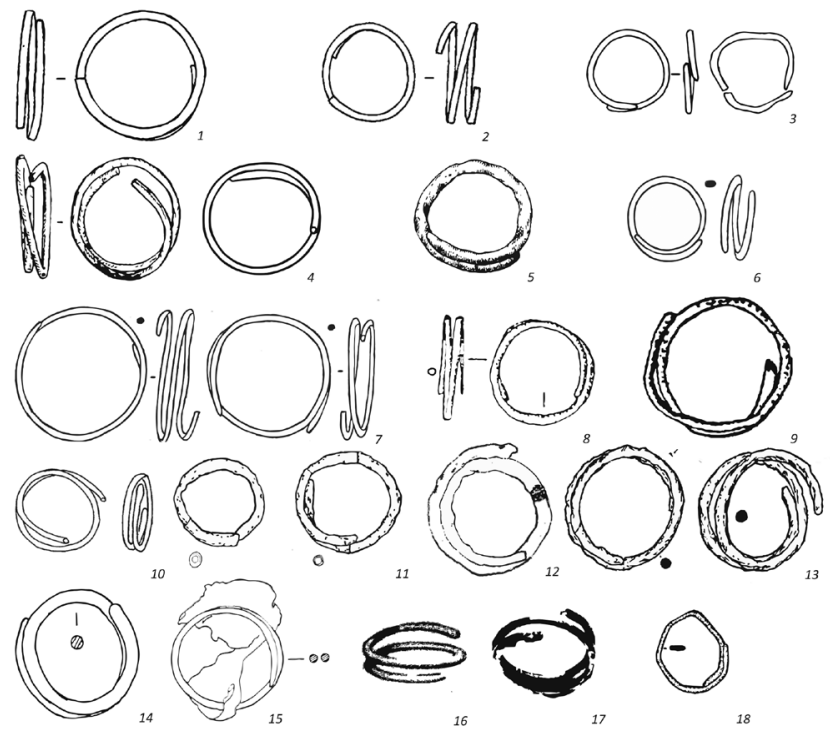

16

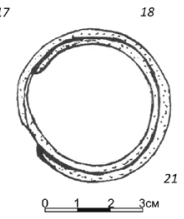

Рис. 2. Спиралевидные височные подвески из погребений ранних кочевников степной зоны Южного Урала IV в. до н.э.: 1 Альмухаметово К6; 2 - Бекешево III К2 П2; 3 - Тавлыкаево IV К2; 4 - Леканды К4 П1; 5 - Матвеевский К3; 6 - Близнецы К1 П4 Череп 2; 7 - Мечет-Сай К8 П4; 8 - Покровка 2 К23 П13; 9 - Черный Яр К20 П5,7; 10 - Новый Кумак К1 П1; 11 - Новоорский I К9 П3; 12 - Новоорский II К2 П3; 13 - Новоорский II К3 П3; 14 - Казачья Губерля I К3 П3; 15 - Казачья Губерля I К3П5; 16 - Челкар III К6 П1; 17 - Челкар III К6П2; 18 - ЛебедевкаV К9 П3; 19 - Жаман-Каргала II К1 П4; 20 - Имангазы-Карасу К3 П2; 21 - Донецкое К2 П3. 


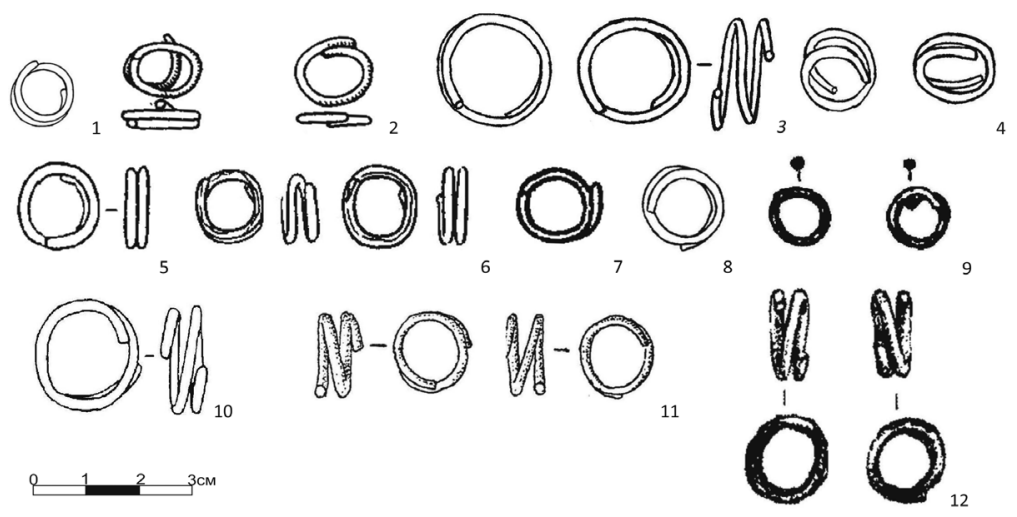

Рис. 3. Спиралевидные височные подвески из погребений ранних кочевников степной зоны Южного Урала IV-III вв. до н.э.: 1 - Леканды К3 П2; 2 - Новопавловка (Уральская) К5 П2; 3 - Мечет-Сай К6 П4; 4 - Мечет-Сай К7 П8; 5 - Мечет-Сай К7 П9; 6 - Мечет-Сай К7 П10; 7 - Мечет-Сай К7 П12-14; 8 - Новый Кумак К20 П6; 9 - Лебедевка V К48 П2; 10 - Лебедевка VII К9 П2; 11 - Покровка 2 К23 П18; 12 - Шумаево II К9 П11. 


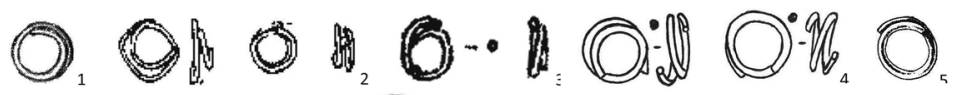
(1) O. $\mathrm{HO}, 0 . \mathrm{M}, 0$.

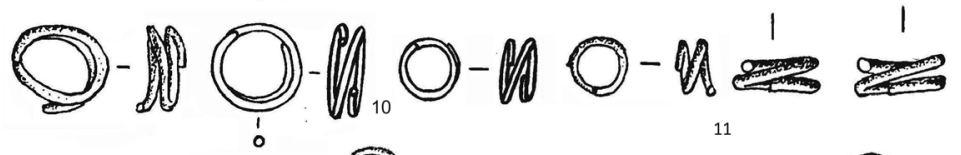

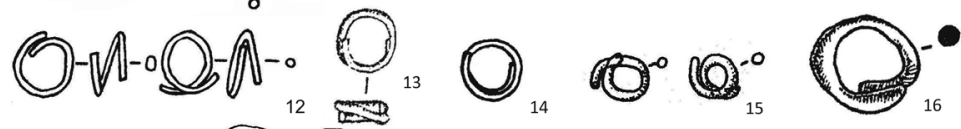

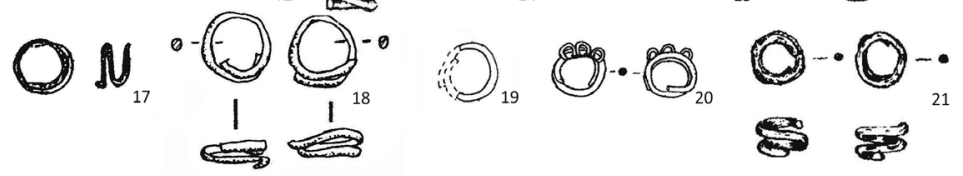

ONOH (0) $10-10,0$

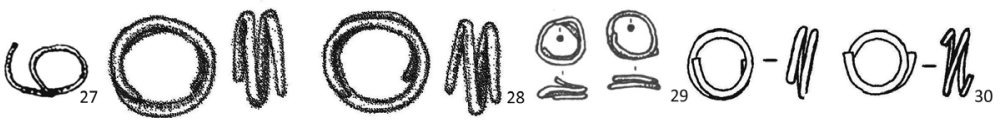
(1) (O) O

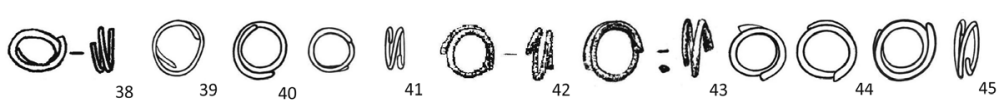
O. O. Q. O- $\mathbb{P}_{0 . \cdots}$ 
Рис. 4. Спиралевидные височные подвески из погребений ранних кочевников степной зоны Южного Урала III-II вв. до н.э.: 1 - Челкар III К9; 2 - Болгарка I П5; 3 - Танаберген II К1 П7; 4 Увак К8 П1; 5 - Мечет-Сай К1 П1; 6 - Мечет-Сай К3 П3; 7 - Покровка 1 К16 П3; 8 - Покровка 2 К7 П1; 9 - Покровка 2 К7 П2; 10 - Покровка 2 К7 П4; 11 - Покровка 2 К7 П7; 12 - Покровка 2 К8 П5; 13 - Покровка 7 К9 П4; 14 - Покровка 7 К9 П9; 15 - Покровка 8 К1 П15; 16 - Покровка 8 К2 П2; 17 - Покровка 8 К6 П1; 18 - Покровка 10 К5 П2; 19 - Покровка 10 К5 П5; 20 - Бердянка V К4 П5; 21 -Бердянка V К5 П2; 22 - Бердянка V К5 П3; 23 - Шумаево II К3 П6; 24 - Шумаево II К3 П9; 25 - Шумаево II К9 П4; 26 - Шумаево II К9 П6; 27 - Прохоровка Кб П2; 28 - Прохоровка К2 П5; 29 - Переволоцкий К1 П4; 30 - Боголюбовка П3; 31 - Бишунгарово К2 П7; 32 - Бишунгарово К3 П6; 33 - Бишунгарово К5 П3; 34 - Бишунгарово К11 П4; 35 - Бишунгарово К11 П7; 36 - Бишунгарово К11 П9; 37 - Бишунгарово К19 П4 костяк 1; 38 - Бишунгарово К19 П4 костяк 2; 39 - Старые Киишки К11 П2; 40 - Старые Киишки К11 П3; 41 - Старые Киишки К11 П16; 42 - Старые Киишки К13 П5; 43 - Старые Киишки К13 П12; 44 - Старые Киишки К14 П7; 45 - Старые Киишки К14 П14; 46 - Старые Киишки К15 П10; 47 Старые Киишки К18 П9; 48 - Старые Киишки К18 П27; 49 - Якутово II КЗ П2. 


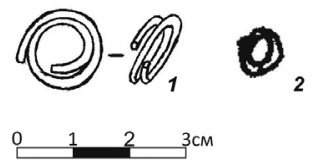

Рис. 5. Спиралевидные височные подвески из погребений ранних кочевников степной зоны Южного Урала II-I вв. до н.э.: 1 - Чкаловский К4 П10; 2 - Жарсуат I К2 П4.

Таблица 1. Спиралевидные височные подвески из погребений ранних кочевников степной зоны Южного Урала.

\begin{tabular}{|c|c|c|c|c|c|}
\hline $\begin{array}{l}\text { № } \\
\text { п/ா }\end{array}$ & Комплексы & Датировка & $\begin{array}{c}\text { Диаметр } \\
\text { колец в } \\
\text { мм. }\end{array}$ & Источники & $\begin{array}{l}\text { Номер рисунка } \\
\text { в статье }\end{array}$ \\
\hline 1. & $\begin{array}{l}\text { Альмухаметово } \\
\text { курган } 6\end{array}$ & IV в. до.н.э. & 40 & $\begin{array}{l}\text { Пшеничнюк, } \\
1983 . \\
\text { Табл. XXXI, } 4\end{array}$ & Рис. 2, 1 \\
\hline 2. & \begin{tabular}{|l} 
Бекешево III \\
курган 2 \\
погребение 2 \\
\end{tabular} & IV в. до.н.э. & 28 & $\begin{array}{l}\text { Пшеничнюк, } \\
1983 . \\
\text { Табл. LI, } 16 \\
\end{array}$ & Рис. 2, 2 \\
\hline 3. & $\begin{array}{l}\text { Тавлыкаево IV } \\
\text { курган } 2\end{array}$ & IV в. до.н.э. & 25 & $\begin{array}{l}\text { Пшеничнюк, } \\
1983 . \\
\text { Табл. XLIX, } 3\end{array}$ & $\begin{array}{l}\text { Рис. 2, } 3 \\
\text { (рисунок автора) }\end{array}$ \\
\hline 4. & $\begin{array}{l}\text { Тавлыкаево IV } \\
\text { курган } 2\end{array}$ & IV в. до.н.э. & 25 & $\begin{array}{l}\text { Пшеничнюк, } \\
1983 . \\
\text { Табл. XLIX, } 3\end{array}$ & $\begin{array}{l}\text { Рис. 2, } 3 \\
\text { (рисунок автора) }\end{array}$ \\
\hline 5. & $\begin{array}{l}\text { Леканды } \\
\text { курган } 4 \\
\text { погребение } 1 \\
\end{array}$ & IV в. до.н.э. & 35 & $\begin{array}{l}\text { Пшеничнюк, } \\
1983 . \\
\text { Табл. VIII, } 2\end{array}$ & $\begin{array}{l}\text { Рис. 2, } 4 \\
\text { (рисунок автора) }\end{array}$ \\
\hline 6. & $\begin{array}{l}\text { Леканды } \\
\text { курган } 4 \\
\text { погребение } 1 \\
\end{array}$ & IV в. до.н.э. & 35 & $\begin{array}{l}\text { Пшеничнюк, } \\
1983 . \\
\text { Табл. VIII, } 2\end{array}$ & $\begin{array}{l}\text { Рис. 2, } 4 \\
\text { (рисунок автора) }\end{array}$ \\
\hline 7. & $\begin{array}{l}\text { Матвеевский } \\
\text { курган } 3 \\
\end{array}$ & IV в. до.н.э. & 30 & $\begin{array}{l}\text { Смирнов, } 1964 . \\
\text { С. } 342, \text { рис. } 48,23 \\
\end{array}$ & Рис. 2, 5 \\
\hline 8. & $\begin{array}{l}\text { Матвеевский } \\
\text { курган } 3\end{array}$ & IV в. до.н.э. & 30 & $\begin{array}{l}\text { Смирнов, } 1964 . \\
\text { С. } 342, \text { рис. } 48,23 \\
\end{array}$ & Рис. 2, 5 \\
\hline 9. & \begin{tabular}{|l} 
Близнецы \\
курган 1 \\
погребение 4 череп 2
\end{tabular} & IV в. до.н.э. & 25 & $\begin{array}{l}\text { Смирнов, } 1957 . \\
\text { Рис. 67, } 4\end{array}$ & $\begin{array}{l}\text { Рис. 2, } 6 \\
\text { (рисунок автора) }\end{array}$ \\
\hline 10. & $\begin{array}{l}\text { Мечет-Сай } \\
\text { курган } 8 \\
\text { погребение } 4\end{array}$ & IV в. до.н.э. & 41 & $\begin{array}{l}\text { Смирнов, } 1957 . \\
\text { Рис. 52, } 10\end{array}$ & $\begin{array}{l}\text { Рис. 2, } 7 \\
\text { (рисунок автора) }\end{array}$ \\
\hline
\end{tabular}




\begin{tabular}{|c|c|c|c|c|c|}
\hline 11. & $\begin{array}{l}\text { Мечет-Сай } \\
\text { курган } 8 \\
\text { погребение } 4\end{array}$ & IV в. до.н.э. & 38 & $\begin{array}{l}\text { Смирнов, } 1957 . \\
\text { Рис. 52, } 10\end{array}$ & $\begin{array}{l}\text { Рис. 2, } 7 \\
\text { (рисунок автора) }\end{array}$ \\
\hline 12. & $\begin{array}{l}\text { Покровка } 2 \\
\text { курган } 23 \\
\text { погребение } 13\end{array}$ & IV в. до.н.э. & 33 & $\begin{array}{l}\text { Яблонский и др., } \\
\text { 1994. Рис.96, } 3\end{array}$ & Рис. 2, 8 \\
\hline 13. & $\begin{array}{l}\text { Черный Яр } \\
\text { курган } 20 \\
\text { погребения 5,7 }\end{array}$ & IV в. до.н.э. & 43 & $\begin{array}{l}\text { Мещеряков, } \\
1997 . \\
\text { С.66, рис.12,6 }\end{array}$ & Рис. 2, 9 \\
\hline 14. & $\begin{array}{l}\text { Новый Кумак } \\
\text { курган } 1 \\
\text { погребение } 1\end{array}$ & IV в. до.н.э. & 30 & $\begin{array}{l}\text { Смирнов, } 1971 . \\
\text { Рис. } 22\end{array}$ & Рис. 2, 10 \\
\hline 15. & $\begin{array}{l}\text { Новый Кумак } \\
\text { курган } 1 \\
\text { погребение } 1 \\
\end{array}$ & IV в. до.н.э. & 30 & $\begin{array}{l}\text { Смирнов, } 1971 . \\
\text { Рис. 25,1 }\end{array}$ & Рис. 2, 10 \\
\hline 16. & $\begin{array}{l}\text { Новоорский I } \\
\text { курган } 9 \\
\text { погребение } 3\end{array}$ & IV в. до.н.э. & 33 & $\begin{array}{l}\text { Заседателева, } \\
1984\end{array}$ & Рис. 2, 11 \\
\hline 17. & $\begin{array}{l}\text { Новоорский I } \\
\text { курган } 9 \\
\text { погребение } 3\end{array}$ & IV в. до.н.э. & 29 & $\begin{array}{l}\text { Заседателева, } \\
1984\end{array}$ & Рис. 2, 11 \\
\hline 18. & $\begin{array}{l}\text { Новоорский II } \\
\text { курган } 2 \\
\text { погребение } 3\end{array}$ & IV в. до.н.э. & 37 & $\begin{array}{l}\text { Заседателева, } \\
1985\end{array}$ & Рис. 2, 12 \\
\hline 19. & $\begin{array}{l}\text { Новоорский II } \\
\text { курган } 3 \\
\text { погребение } 3 \\
\end{array}$ & IV в. до.н.э. & 35 & $\begin{array}{l}\text { Заседателева, } \\
\text { 1989. Рис. 9,1 }\end{array}$ & Рис. 2, 13 \\
\hline 20. & $\begin{array}{l}\text { Новоорский II } \\
\text { курган } 3 \\
\text { погребение } 3\end{array}$ & IV в. до.н.э. & 35 & $\begin{array}{l}\text { Заседателева, } \\
\text { 1989. Рис. 9,1 }\end{array}$ & Рис. 2, 13 \\
\hline 21. & $\begin{array}{l}\text { Казачья Губерля I } \\
\text { курган } 3 \\
\text { погребение } 3\end{array}$ & IV в. до.н.э. & 37 & \begin{tabular}{|l} 
Бытковский, \\
1998. Рис. 47, 48
\end{tabular} & Рис. 2, 14 \\
\hline 22. & $\begin{array}{l}\text { Казачья Губерля I } \\
\text { курган } 3 \\
\text { погребение } 5\end{array}$ & IV в. до.н.э. & 32 & $\begin{array}{l}\text { Бытковский, } \\
\text { 1998. Рис. 67, } 68\end{array}$ & Рис. 2, 15 \\
\hline 23. & $\begin{array}{l}\text { Челкар III } \\
\text { курган } 6 \\
\text { погребение } 1 \\
\end{array}$ & IV в. до.н.э. & 30 & $\begin{array}{l}\text { Мошкова, } \\
\text { Кушаев, } 1973 . \\
\text { С. 263, рис. 4, } 7 \\
\end{array}$ & Рис. 2, 16 \\
\hline 24. & \begin{tabular}{|l} 
Челкар III \\
курган 6 \\
погребение 1
\end{tabular} & IV в. до.н.э. & 30 & \begin{tabular}{|l|} 
Мошкова, \\
Кушаев, 1973. \\
С. 263, рис. 4, 7
\end{tabular} & Рис. 2, 16 \\
\hline 25. & $\begin{array}{l}\text { Челкар III } \\
\text { курган } 6 \\
\text { погребение } 2 \\
\end{array}$ & IV в. до.н.э. & 30 & $\begin{array}{l}\text { Мошкова, } \\
\text { Кушаев, } 1973 . \\
\text { С. 263, рис. 4, } 8 \\
\end{array}$ & Рис. 2, 17 \\
\hline 26. & $\begin{array}{l}\text { Челкар III } \\
\text { курган } 6 \\
\text { погребение } 2 \\
\end{array}$ & IV в. до.н.э. & 30 & $\begin{array}{l}\text { Мошкова, } \\
\text { Кушае, } 1973 . \\
\text { С. 263, рис. 4, } 8 \\
\end{array}$ & Рис. 2, 17 \\
\hline
\end{tabular}




\begin{tabular}{|c|c|c|c|c|c|}
\hline 27. & \begin{tabular}{|l|} 
ЛебедевкаV \\
курган 9 \\
погребение 3
\end{tabular} & IV в. до.н.э. & 25 & $\begin{array}{l}\text { Железчиков и } \\
\text { др., } 2006 . \\
\text { Рис. } 24,3\end{array}$ & Рис. 2, 18 \\
\hline 28. & $\begin{array}{l}\text { Жаман-Каргала II } \\
\text { курган } 1 \\
\text { погребение } 4\end{array}$ & IV в. до.н.э. & 33 & $\begin{array}{l}\text { Гуцалов , } 1985 . \\
\text { Рис. } 15 \text { a, } 12\end{array}$ & Рис. 2, 19 \\
\hline 29. & $\begin{array}{l}\text { Жаман-Каргала II } \\
\text { курган } 1 \\
\text { погребение } 4\end{array}$ & IV в. до.н.э & 33 & $\begin{array}{l}\text { Гуцалов, } 1985 . \\
\text { Рис. } 15 \text { a, } 12\end{array}$ & Рис. 2, 19 \\
\hline 30. & $\begin{array}{l}\text { Имангазы-Карасу } \\
\text { курган } 3 \\
\text { погребение } 2\end{array}$ & IV в. до.н.э & 28 & $\begin{array}{l}\text { Родионов, } \\
\text { Гуцалов, 2000 } \\
\text { С.140, рис. 5, } 88\end{array}$ & Рис. 2,20 \\
\hline 31. & $\begin{array}{l}\text { Имангазы-Карасу } \\
\text { курган } 3 \\
\text { погребение } 2\end{array}$ & IV в. до.н.э & 28 & $\begin{array}{l}\text { Родионов, } \\
\text { Гуцалов, 2000. } \\
\text { С.140, рис. 5, } 88\end{array}$ & Рис. 2, 20 \\
\hline 32. & $\begin{array}{l}\text { Донецкое } \\
\text { курган } 2 \\
\text { погребение } 3 \\
\end{array}$ & IV в. до.н.э. & 35 & $\begin{array}{l}\text { Матюшко и др., } \\
\text { 2016. С.112, } \\
\text { рис. 10, } 10\end{array}$ & Рис. 2, 21 \\
\hline 33. & $\begin{array}{l}\text { Леканды } \\
\text { курган } 3 \\
\text { погребение } 2 \\
\end{array}$ & $\begin{array}{l}\text { IV-III вв. } \\
\text { до.н.э. }\end{array}$ & 12 & \begin{tabular}{|l|} 
Пшеничнюк, \\
1983. Табл. VII, 21
\end{tabular} & Рис. 3, 1 \\
\hline 34. & $\begin{array}{l}\text { Новопавловка } \\
\text { (Уральская) } \\
\text { курган } 5 \\
\text { погребение } 2 \\
\end{array}$ & $\begin{array}{l}\text { IV-III вв. } \\
\text { до.н.э. }\end{array}$ & 15 & $\begin{array}{l}\text { Железчиков, } \\
\text { Кригер, } 1978 . \\
\text { Рис. 2,14 }\end{array}$ & Рис. 3, 2 \\
\hline 35. & $\begin{array}{l}\text { Новопавловка } \\
\text { (Уральская) } \\
\text { курган } 5 \text { погребение } 2\end{array}$ & $\begin{array}{l}\text { IV-III вв. } \\
\text { до.н.э. }\end{array}$ & 15 & $\begin{array}{l}\text { Железчиков, } \\
\text { Кригер, } 1978 . \\
\text { Рис. 2,14 }\end{array}$ & Рис. 3,2 \\
\hline 36. & $\begin{array}{l}\text { Мечет-Сай } \\
\text { курган } 6 \\
\text { погребение } 4\end{array}$ & $\begin{array}{l}\text { IV-III вв. } \\
\text { до.н.э. }\end{array}$ & 24 & $\begin{array}{l}\text { Смирнов, } 1961 . \\
\text { Рис. } 87\end{array}$ & $\begin{array}{l}\text { Рис. } 3,3 \\
\text { (рисунок автора) }\end{array}$ \\
\hline 37. & $\begin{array}{l}\text { Мечет-Сай } \\
\text { курган } 6 \\
\text { погребение } 4\end{array}$ & $\begin{array}{l}\text { IV-III вв. } \\
\text { до.н.э. }\end{array}$ & 24 & $\begin{array}{l}\text { Смирнов, } 1961 . \\
\text { Рис. } 87\end{array}$ & $\begin{array}{l}\text { Рис. } 3,3 \\
\text { (рисунок автора) }\end{array}$ \\
\hline 38. & $\begin{array}{l}\text { Мечет-Сай } \\
\text { курган } 7 \\
\text { погребение } 8 \\
\end{array}$ & $\begin{array}{l}\text { IV-III вв. } \\
\text { до.н.э. }\end{array}$ & 15 & $\begin{array}{l}\text { Смирнов, } 1957 . \\
\text { Рис. } 127\end{array}$ & $\begin{array}{l}\text { Рис. } 3,4 \\
\text { (рисунок автора) }\end{array}$ \\
\hline 39. & $\begin{array}{l}\text { Мечет-Сай } \\
\text { курган } 7 \\
\text { погребение } 8\end{array}$ & $\begin{array}{l}\text { IV-III вв. } \\
\text { до.н.э. }\end{array}$ & 15 & $\begin{array}{l}\text { Смирнов, } 1957 . \\
\text { Рис. } 127\end{array}$ & $\begin{array}{l}\text { Рис. } 3,4 \\
\text { (рисунок автора) }\end{array}$ \\
\hline 40. & $\begin{array}{l}\text { Мечет-Сай } \\
\text { курган } 7 \\
\text { погребение } 9\end{array}$ & $\begin{array}{l}\text { IV-III вв. } \\
\text { до.н.э. }\end{array}$ & 15 & $\begin{array}{l}\text { Смирнов, } 1975 . \\
\text { С. } 126 \text {, рис. } 46,1\end{array}$ & Рис. 3,5 \\
\hline 41. & $\begin{array}{l}\text { Мечет-Сай } \\
\text { курган } 7 \\
\text { погребение } 10\end{array}$ & $\begin{array}{l}\text { IV-III вв. } \\
\text { до.н.э. }\end{array}$ & 15 & $\begin{array}{l}\text { Смирнов, } 1975 . \\
\text { С. } 126, \text { рис. } 47,4\end{array}$ & Рис. 3,6 \\
\hline
\end{tabular}




\begin{tabular}{|c|c|c|c|c|c|}
\hline 42. & $\begin{array}{l}\text { Мечет-Сай } \\
\text { курган } 7 \\
\text { погребение } 10\end{array}$ & $\begin{array}{l}\text { IV-III вв. } \\
\text { до.н.э. }\end{array}$ & 15 & $\begin{array}{l}\text { Смирнов, } 1975 . \\
\text { С. } 126, \text { рис. } 47,4\end{array}$ & Рис. 3,6 \\
\hline 43. & \begin{tabular}{|l} 
Мечет-Сай \\
курган 7 \\
погребение 12-14
\end{tabular} & $\begin{array}{l}\text { IV-III вв. } \\
\text { до.н.э. }\end{array}$ & 15 & $\begin{array}{l}\text { Смирнов, } 1975 . \\
\text { С. } 129 \text {, рис. } 49,1\end{array}$ & Рис. 3,7 \\
\hline 44. & $\begin{array}{l}\text { Новый Кумак } \\
\text { курган } 20 \\
\text { погребение } 6\end{array}$ & $\begin{array}{l}\text { IV-III вв. } \\
\text { до.н.э. }\end{array}$ & 15 & $\begin{array}{l}\text { Смирнов, } 1972 . \\
\text { Рис. } 71\end{array}$ & $\begin{array}{l}\text { Рис. } 3,8 \\
\text { (рисунок автора) }\end{array}$ \\
\hline 45. & $\begin{array}{l}\text { ЛебедевкаV } \\
\text { курган } 48 \\
\text { погребение } 2\end{array}$ & $\begin{array}{l}\text { IV-III вв. } \\
\text { до.н.э. }\end{array}$ & 11 & $\begin{array}{l}\text { Железчиков } \\
\text { и др., 2006. } \\
\text { Рис. 45,6 }\end{array}$ & Рис. 3, 9 \\
\hline 46. & $\begin{array}{l}\text { Лебедевка V } \\
\text { курган } 48 \\
\text { погребение } 2 \\
\end{array}$ & $\begin{array}{l}\text { IV-III вв. } \\
\text { до.н.э. }\end{array}$ & 11 & $\begin{array}{l}\text { Железчиков } \\
\text { и др., } 2006 . \\
\text { Рис. } 45,6 \\
\end{array}$ & Рис. 3,9 \\
\hline 47. & $\begin{array}{l}\text { Лебедевка VII } \\
\text { курган } 9 \\
\text { погребение } 2\end{array}$ & $\begin{array}{l}\text { IV-III вв. } \\
\text { до.н.э. }\end{array}$ & 21 & $\begin{array}{l}\text { Железчиков } \\
\text { и др., 2006. } \\
\text { Рис. 65,5 }\end{array}$ & Рис. 3, 10 \\
\hline 48. & $\begin{array}{l}\text { Лебедевка VII } \\
\text { курган } 9 \\
\text { погребение } 2 \\
\end{array}$ & $\begin{array}{l}\text { IV-III вв. } \\
\text { до.н.э. }\end{array}$ & 21 & $\begin{array}{l}\text { Железчиков } \\
\text { и др., } 2006 . \\
\text { Рис. 65,5 } \\
\end{array}$ & Рис. 3,10 \\
\hline 49. & $\begin{array}{l}\text { Покровка } 2 \\
\text { курган } 23 \\
\text { погребение } 18\end{array}$ & $\begin{array}{l}\text { IV-III вв. } \\
\text { до.н.э. }\end{array}$ & 15 & $\begin{array}{l}\text { Яблонский и др., } \\
\text { 1994. Рис.99,1,2 }\end{array}$ & Рис. 3,11 \\
\hline 50. & $\begin{array}{l}\text { Покровка } 2 \\
\text { курган } 23 \\
\text { погребение } 18 \\
\end{array}$ & $\begin{array}{l}\text { IV-III вв. } \\
\text { до.н.э. }\end{array}$ & 15 & $\begin{array}{l}\text { Яблонский и др., } \\
\text { 1994. Рис.99,1,2 }\end{array}$ & Рис. 3,11 \\
\hline 51. & $\begin{array}{l}\text { Шумаево II } \\
\text { курган 9 } \\
\text { погребение } 11\end{array}$ & $\begin{array}{l}\text { IV-III вв. } \\
\text { до.н.э. }\end{array}$ & 14 & $\begin{array}{l}\text { Моргунова и др., } \\
\text { 2003. Рис. 91,3 }\end{array}$ & Рис. 3,12 \\
\hline 52. & $\begin{array}{l}\text { Шумаево II } \\
\text { курган } 9 \\
\text { погребение } 11 \\
\end{array}$ & $\begin{array}{l}\text { IV-III вв. } \\
\text { до.н.э. }\end{array}$ & 14 & $\begin{array}{l}\text { Моргунова и др., } \\
\text { 2003. Рис. 91,3 }\end{array}$ & Рис. 3,12 \\
\hline 53. & $\begin{array}{l}\text { Челкар III } \\
\text { курган } 9\end{array}$ & $\begin{array}{l}\text { III-II вв. } \\
\text { до.н.э. }\end{array}$ & 12 & \begin{tabular}{|l|} 
Мошкова, 1969. \\
Рис. 36
\end{tabular} & Рис. 4,1 \\
\hline 54. & \begin{tabular}{|l} 
Болгарка I \\
погребение 5
\end{tabular} & $\begin{array}{l}\text { III-II вв. } \\
\text { до.н.э. }\end{array}$ & 10 & \begin{tabular}{|l} 
Гуцалов \\
Родионова, 1984
\end{tabular} & Рис. 4, 2 \\
\hline 55. & \begin{tabular}{|l} 
Болгарка I \\
погребение 5
\end{tabular} & $\begin{array}{l}\text { III-II вв. } \\
\text { до.н.э. }\end{array}$ & 10 & \begin{tabular}{|l|}
$\begin{array}{l}\text { Гуцалов, } \\
\text { Родионова, } 1984\end{array}$ \\
\end{tabular} & Рис. 4, 2 \\
\hline 56. & $\begin{array}{l}\text { Танаберген II } \\
\text { курган 1 } \\
\text { погребение } 7\end{array}$ & $\begin{array}{l}\text { III-II вв. } \\
\text { до.н.э. }\end{array}$ & 15 & $\begin{array}{l}\text { Гуцалов, } 1991 . \\
\text { С. } 7\end{array}$ & Рис. 4,3 \\
\hline 57. & \begin{tabular}{|l} 
Увак \\
курган 8 \\
погребение 1 \\
\end{tabular} & $\begin{array}{l}\text { III-II вв. } \\
\text { до.н.э. }\end{array}$ & 12 & $\begin{array}{l}\text { Смирнов, } 1975 . \\
\text { С. } 67 \text {, рис. } 21,4\end{array}$ & Рис. 4,4 \\
\hline 58. & \begin{tabular}{|l} 
Увак \\
курган 8 \\
погребение 1 \\
\end{tabular} & $\begin{array}{l}\text { III-II вв. } \\
\text { до.н.э. }\end{array}$ & 12 & $\begin{array}{l}\text { Смирнов, } 1975 . \\
\text { С. } 67 \text {, рис. } 21,4\end{array}$ & Рис. 4,4 \\
\hline
\end{tabular}




\begin{tabular}{|c|c|c|c|c|c|}
\hline 59. & $\begin{array}{l}\text { Мечет-Сай } \\
\text { курган } 1 \\
\text { погребение } 1 \\
\end{array}$ & $\begin{array}{l}\text { III-II вв. } \\
\text { до.н.э. }\end{array}$ & 12 & $\begin{array}{l}\text { Мошкова, } 1963 . \\
\text { Табл. 29,13 }\end{array}$ & Рис. 4, 5 \\
\hline 60. & $\begin{array}{l}\text { Мечет-Сай } \\
\text { курган } 3 \\
\text { погребение } 3\end{array}$ & $\begin{array}{l}\text { III-II вв. } \\
\text { до.н.э. }\end{array}$ & 14 & $\begin{array}{l}\text { Смирнов, } 1961 . \\
\text { Рис. } 15\end{array}$ & $\begin{array}{l}\text { Рис. } 4,6 \\
\text { (рисунок автора) }\end{array}$ \\
\hline 61. & $\begin{array}{l}\text { Мечет-Сай } \\
\text { курган } 3 \\
\text { погребение } 3 \\
\end{array}$ & $\begin{array}{l}\text { III-II вв. } \\
\text { до.н.э. }\end{array}$ & 14 & $\begin{array}{l}\text { Смирнов, } 1961 . \\
\text { Рис. } 15\end{array}$ & $\begin{array}{l}\text { Рис. } 4,6 \\
\text { (рисунок автора) }\end{array}$ \\
\hline 62. & \begin{tabular}{|l} 
Покровка 1 \\
курган 16 \\
погребение 3 \\
\end{tabular} & $\begin{array}{l}\text { III-II вв. } \\
\text { до.н.э. }\end{array}$ & 18 & $\begin{array}{l}\text { Яблонский и др., } \\
\text { 1994. Рис. 45,4 }\end{array}$ & Рис. 4, 7 \\
\hline 63. & \begin{tabular}{|l} 
Покровка 2 \\
курган 7 \\
погребение 1 \\
\end{tabular} & $\begin{array}{l}\text { III-II вв. } \\
\text { до.н.э. }\end{array}$ & 13 & $\begin{array}{l}\text { Яблонский и др., } \\
\text { 1995. Рис. 51,3 }\end{array}$ & Рис. 4, 8 \\
\hline 64. & \begin{tabular}{|l} 
Покровка 2 \\
курган 7 \\
погребение 2 \\
\end{tabular} & $\begin{array}{l}\text { III-II вв. } \\
\text { до.н.э. }\end{array}$ & 19 & $\begin{array}{l}\text { Яблонский и др., } \\
\text { 1995. Рис. 51,5 }\end{array}$ & Рис. 4, 9 \\
\hline 65. & \begin{tabular}{|l} 
Покровка 2 \\
курган 7 \\
погребение 2 \\
\end{tabular} & $\begin{array}{l}\text { III-II вв. } \\
\text { до.н.э. }\end{array}$ & 19 & $\begin{array}{l}\text { Яблонский и др., } \\
\text { 1995. Рис. 51,5 }\end{array}$ & Рис. 4, 9 \\
\hline 66. & \begin{tabular}{|l} 
Покровка 2 \\
курган 7 \\
погребение 4 \\
\end{tabular} & $\begin{array}{l}\text { III-II вв. } \\
\text { до.н.э. }\end{array}$ & 18 & $\begin{array}{l}\text { Яблонский и др., } \\
\text { 1995. Рис. 53,1,2 }\end{array}$ & Рис. 4, 10 \\
\hline 67. & $\begin{array}{l}\text { Покровка } 2 \\
\text { курган } 7 \\
\text { погребение } 4 \\
\end{array}$ & $\begin{array}{l}\text { III-II вв. } \\
\text { до.н.э. }\end{array}$ & 18 & $\begin{array}{l}\text { Яблонский и др., } \\
\text { 1995. Рис. 53,1,2 }\end{array}$ & Рис. 4, 10 \\
\hline 68. & \begin{tabular}{|l} 
Покровка 2 \\
курган 7 \\
погребение 7 \\
\end{tabular} & $\begin{array}{l}\text { III-II вв. } \\
\text { до.н.э. }\end{array}$ & 12 & $\begin{array}{l}\text { Яблонский и др., } \\
\text { 1995. Рис. 53,11 }\end{array}$ & Рис. 4, 11 \\
\hline 69. & $\begin{array}{l}\text { Покровка } 2 \\
\text { курган } 7 \\
\text { погребение } 7\end{array}$ & $\begin{array}{l}\text { III-II вв. } \\
\text { до.н.э. }\end{array}$ & 12 & $\begin{array}{l}\text { Яблонский и др., } \\
\text { 1995. Рис. 53,11 }\end{array}$ & Рис. 4, 11 \\
\hline 70. & $\begin{array}{l}\text { Покровка } 2 \\
\text { курган } 8 \\
\text { погребение } 5\end{array}$ & $\begin{array}{l}\text { III-II вв. } \\
\text { до.н.э. }\end{array}$ & 20 & $\begin{array}{l}\text { Яблонский и др., } \\
\text { 1995. Рис. 57,1,2 }\end{array}$ & Рис. 4, 12 \\
\hline 71. & $\begin{array}{l}\text { Покровка } 2 \\
\text { курган } 8 \\
\text { погребение } 5\end{array}$ & $\begin{array}{l}\text { III-II вв. } \\
\text { до.н.э. }\end{array}$ & 20 & $\begin{array}{l}\text { Яблонский и др., } \\
\text { 1995. Рис. 57,1,2 }\end{array}$ & Рис. 4, 12 \\
\hline 72. & $\begin{array}{l}\text { Покровка } 7 \\
\text { курган } 9 \\
\text { погребение } 4 \\
\end{array}$ & $\begin{array}{l}\text { III-II вв. } \\
\text { до.н.э. }\end{array}$ & 13 & $\begin{array}{l}\text { Яблонский и др., } \\
\text { 1996. Рис. 50, } 2\end{array}$ & Рис. 4, 13 \\
\hline 73. & $\begin{array}{l}\text { Покровка } 7 \\
\text { курган } 9 \\
\text { погребение } 9\end{array}$ & $\begin{array}{l}\text { III-II вв. } \\
\text { до.н.э. }\end{array}$ & 12 & $\begin{array}{l}\text { Яблонский и др., } \\
\text { 1996. Рис. 53, } 10\end{array}$ & Рис. 4,14 \\
\hline 74. & $\begin{array}{l}\text { Покровка } 8 \\
\text { курган } 1 \\
\text { погребение } 15\end{array}$ & $\begin{array}{l}\text { III-II вв. } \\
\text { до.н.э. }\end{array}$ & 10 & $\begin{array}{l}\text { Веддер и др., } \\
\text { 1993. Рис. 53,8 }\end{array}$ & Рис. 4, 15 \\
\hline
\end{tabular}




\begin{tabular}{|c|c|c|c|c|c|}
\hline 75. & $\begin{array}{l}\text { Покровка } 8 \\
\text { курган } 1 \\
\text { погребение } 15\end{array}$ & $\begin{array}{l}\text { III-II вв. } \\
\text { до.н.э. }\end{array}$ & 10 & $\begin{array}{l}\text { Веддер и др., } \\
\text { 1993. Рис. 53,8 }\end{array}$ & Рис. 4, 15 \\
\hline 76. & $\begin{array}{l}\text { Покровка } 8 \\
\text { курган } 2 \\
\text { погребение } 2\end{array}$ & $\begin{array}{l}\text { III-II вв. } \\
\text { до.н.э. }\end{array}$ & 20 & $\begin{array}{l}\text { Веддер и др., } \\
\text { 1993. Рис. 54,1 }\end{array}$ & Рис. 4,16 \\
\hline 77. & $\begin{array}{l}\text { Покровка } 8 \\
\text { курган } 6 \\
\text { погребение } 1\end{array}$ & $\begin{array}{l}\text { III-II вв. } \\
\text { до.н.э. }\end{array}$ & 12 & $\begin{array}{l}\text { Веддер и др., } \\
\text { 1993. Рис. 57,10 }\end{array}$ & Рис. 4, 17 \\
\hline 78. & $\begin{array}{l}\text { Покровка } 8 \\
\text { курган } 6 \\
\text { погребение } 1\end{array}$ & $\begin{array}{l}\text { III-II вв. } \\
\text { до.н.э. }\end{array}$ & 12 & $\begin{array}{l}\text { Веддер и др., } \\
\text { 1993. Рис. 57,10 }\end{array}$ & Рис. 4, 17 \\
\hline 79. & $\begin{array}{l}\text { Покровка } 10 \\
\text { курган } 5 \\
\text { погребение } 2\end{array}$ & $\begin{array}{l}\text { III-II вв. } \\
\text { до.н.э. }\end{array}$ & 13 & $\begin{array}{l}\text { Малашев, } 2002 . \\
\text { Рис 41, 1,2 }\end{array}$ & Рис. 4, 18 \\
\hline 80. & $\begin{array}{l}\text { Покровка } 10 \\
\text { курган } 5 \\
\text { погребение } 2\end{array}$ & $\begin{array}{l}\text { III-II вв. } \\
\text { до.н.э. }\end{array}$ & 14 & $\begin{array}{l}\text { Малашев, } 2002 . \\
\text { Рис 41, 1,2 }\end{array}$ & Рис. 4,18 \\
\hline 81. & $\begin{array}{l}\text { Покровка } 10 \\
\text { курган } 5 \\
\text { погребение } 5\end{array}$ & $\begin{array}{l}\text { III-II вв. } \\
\text { до.н.э. }\end{array}$ & 12 & $\begin{array}{l}\text { Малашев, } 2002 . \\
\text { Рис 53, } 3\end{array}$ & Рис. 4,19 \\
\hline 82. & $\begin{array}{l}\text { Бердянка V } \\
\text { курган } 4 \\
\text { погребение } 5\end{array}$ & $\begin{array}{l}\text { III-II вв. } \\
\text { до.н.э. }\end{array}$ & 11 & $\begin{array}{l}\text { Моргунова, } \\
\text { Мещеряков, } 1999 . \\
\text { Рис. 2, 6а }\end{array}$ & Рис. 4, 20 \\
\hline 83. & $\begin{array}{l}\text { Бердянка V } \\
\text { курган } 4 \\
\text { погребение } 5\end{array}$ & $\begin{array}{l}\text { III-II вв. } \\
\text { до.н.э. }\end{array}$ & 11 & $\begin{array}{l}\text { Моргунова, } \\
\text { Мещеряков, } 1999 . \\
\text { Рис. 2, 6а }\end{array}$ & Рис. 4, 20 \\
\hline 84. & $\begin{array}{l}\text { Бердянка V } \\
\text { курган } 5 \\
\text { погребение } 2\end{array}$ & $\begin{array}{l}\text { III-II вв. } \\
\text { до.н.э. }\end{array}$ & 12 & $\begin{array}{l}\text { Моргунова, } \\
\text { Мещеряков, } 1999 . \\
\text { Рис. 7, } 5\end{array}$ & Рис. 4, 21 \\
\hline 85. & $\begin{array}{l}\text { Бердянка V } \\
\text { курган } 5 \\
\text { погребение } 2\end{array}$ & $\begin{array}{l}\text { III-II вв. } \\
\text { до.н.э. }\end{array}$ & 12 & $\begin{array}{l}\text { Моргунова, } \\
\text { Мещеряков, } 1999 . \\
\text { Рис. 7, } 5\end{array}$ & Рис. 4, 21 \\
\hline 86. & $\begin{array}{l}\text { Бердянка V } \\
\text { курган } 5 \\
\text { погребение } 3\end{array}$ & $\begin{array}{l}\text { III-II вв. } \\
\text { до.н.э. }\end{array}$ & 12 & $\begin{array}{l}\text { Моргунова, } \\
\text { Мещеряков, } 1999 . \\
\text { Рис. } 8,6\end{array}$ & Рис. 4, 22 \\
\hline 87. & $\begin{array}{l}\text { Бердянка V } \\
\text { курган } 5 \\
\text { погребение } 3\end{array}$ & $\begin{array}{l}\text { III-II вв. } \\
\text { до.н.э. }\end{array}$ & 12 & $\begin{array}{l}\text { Моргунова, } \\
\text { Мещеряков, } 1999 . \\
\text { Рис. } 8,6\end{array}$ & Рис. 4, 22 \\
\hline 88. & $\begin{array}{l}\text { Шумаево II } \\
\text { курган } 3 \\
\text { погребение } 6\end{array}$ & $\begin{array}{l}\text { III-II вв. } \\
\text { до.н.э. }\end{array}$ & 11 & $\begin{array}{l}\text { Моргунова и др., } \\
\text { 2003. Рис. 44, 1,2 }\end{array}$ & Рис. 4, 23 \\
\hline 89. & $\begin{array}{l}\text { Шумаево II } \\
\text { курган } 3 \\
\text { погребение } 6\end{array}$ & $\begin{array}{l}\text { III-II вв. } \\
\text { до.н.э. }\end{array}$ & 11 & $\begin{array}{l}\text { Моргунова и др., } \\
\text { 2003. Рис. 44, 1,2 }\end{array}$ & Рис. 4, 23 \\
\hline 90. & $\begin{array}{l}\text { Шумаево II } \\
\text { курган } 3 \\
\text { погребение } 9\end{array}$ & $\begin{array}{l}\text { III-II вв. } \\
\text { до.н.э. }\end{array}$ & 20 & $\begin{array}{l}\text { Моргунова и др., } \\
\text { 2003. Рис. 47, 4,5 }\end{array}$ & Рис. 4, 24 \\
\hline
\end{tabular}




\begin{tabular}{|c|c|c|c|c|c|}
\hline 91. & $\begin{array}{l}\text { Шумаево II } \\
\text { курган } 3 \\
\text { погребение } 9 \\
\end{array}$ & $\begin{array}{l}\text { III-II вв. } \\
\text { до.н.э. }\end{array}$ & 20 & $\begin{array}{l}\text { Моргунова и др., } \\
\text { 2003. Рис. } 47,4,5\end{array}$ & Рис. 4, 24 \\
\hline 92. & $\begin{array}{l}\text { Шумаево II } \\
\text { курган } 9 \\
\text { погребение } 4\end{array}$ & $\begin{array}{l}\text { III-II вв. } \\
\text { до.н.э. }\end{array}$ & 10 & $\begin{array}{l}\text { Моргунова и др., } \\
\text { 2003. Рис. } 83,7\end{array}$ & Рис. 4, 25 \\
\hline 93. & $\begin{array}{l}\text { Шумаево II } \\
\text { курган } 9 \\
\text { погребение } 6 \\
\end{array}$ & $\begin{array}{l}\text { III-II вв. } \\
\text { до.н.э. }\end{array}$ & 12 & $\begin{array}{l}\text { Моргунова и др., } \\
\text { 2003. Рис. } 85,9\end{array}$ & Рис. 4, 26 \\
\hline 94. & $\begin{array}{l}\text { Шумаево II } \\
\text { курган } 9 \\
\text { погребение } 6\end{array}$ & $\begin{array}{l}\text { III-II вв. } \\
\text { до.н.э. }\end{array}$ & 12 & $\begin{array}{l}\text { Моргунова и др., } \\
\text { 2003. Рис. } 85,9\end{array}$ & Рис. 4, 26 \\
\hline 95. & \begin{tabular}{|l} 
Прохоровка \\
курган б \\
погребение 2 \\
\end{tabular} & $\begin{array}{l}\text { III-II вв. } \\
\text { до.н.э. }\end{array}$ & 10 & $\begin{array}{l}\text { Яблонский, } 2003 . \\
\text { Рис. 226, } 3\end{array}$ & Рис. 4, 27 \\
\hline 96. & $\begin{array}{l}\text { Прохоровка } \\
\text { курган } 6 \\
\text { погребение } 2\end{array}$ & $\begin{array}{l}\text { III-II вв. } \\
\text { до.н.э. }\end{array}$ & 10 & $\begin{array}{l}\text { Яблонский, } 2003 . \\
\text { Рис. 226, } 3\end{array}$ & Рис. 4, 27 \\
\hline 97. & $\begin{array}{l}\text { Прохоровка } \\
\text { курган } 2 \\
\text { погребение } 5\end{array}$ & $\begin{array}{l}\text { III-II вв. } \\
\text { до.н.э. }\end{array}$ & 20 & $\begin{array}{l}\text { Яблонский, } 2003 . \\
\text { Рис. 195, 5,6 }\end{array}$ & Рис. 4, 28 \\
\hline 98. & \begin{tabular}{|l} 
Прохоровка \\
курган 2 \\
погребение 5
\end{tabular} & $\begin{array}{l}\text { III-II вв. } \\
\text { до.н.э. }\end{array}$ & 20 & $\begin{array}{l}\text { Яблонский, } 2003 . \\
\text { Рис. 195, 5,6 }\end{array}$ & Рис. 4, 28 \\
\hline 99. & $\begin{array}{l}\text { Переволоцкий } \\
\text { курган } 1 \\
\text { погребение } 4\end{array}$ & $\begin{array}{l}\text { III-II вв. } \\
\text { до.н.э. }\end{array}$ & 10 & $\begin{array}{l}\text { Моргунова и др., } \\
\text { 2016. С.28, рис. } \\
5,4,5\end{array}$ & Рис. 4, 29 \\
\hline 100. & $\begin{array}{l}\text { Переволоцкий } \\
\text { курган } 1 \\
\text { погребение } 4\end{array}$ & $\begin{array}{l}\text { III-II вв. } \\
\text { до.н.э. }\end{array}$ & 10 & $\begin{array}{l}\text { Моргунова и др., } \\
2016 . \text { С.28, рис. } \\
5,4,5\end{array}$ & Рис. 4, 29 \\
\hline 101. & $\begin{array}{l}\text { Боголюбовка } \\
\text { погребение } 3\end{array}$ & $\begin{array}{l}\text { III-II вв. } \\
\text { до.н.э. }\end{array}$ & 13 & \begin{tabular}{|l|} 
Пшеничнюк, \\
1983. С. 18 \\
\end{tabular} & $\begin{array}{l}\text { Рис. } 4,30 \\
\text { (рисунок автора) }\end{array}$ \\
\hline 102. & $\begin{array}{l}\text { Боголюбовка } \\
\text { Погребение } 3\end{array}$ & $\begin{array}{l}\text { III-II вв. } \\
\text { до.н.э. }\end{array}$ & 14 & $\begin{array}{l}\text { Пшеничнюк, } \\
\text { 1983. С. } 18\end{array}$ & $\begin{array}{l}\text { Рис. } 4,30 \\
\text { (рисунок автора) }\end{array}$ \\
\hline 103. & \begin{tabular}{|l} 
Бишунгарово \\
курган 2 \\
погребение 7 \\
\end{tabular} & $\begin{array}{l}\text { III-II вв. } \\
\text { до.н.э. }\end{array}$ & 15 & $\begin{array}{l}\text { Пшеничнюк, } \\
\text { 1983. Табл. XII, } 9\end{array}$ & $\begin{array}{l}\text { Рис. } 4,31 \\
\text { (рисунок автора) }\end{array}$ \\
\hline 104. & \begin{tabular}{|l} 
Бишунгарово \\
курган 3 \\
погребение 6 \\
\end{tabular} & $\begin{array}{l}\text { III-II вв. } \\
\text { до.н.э. }\end{array}$ & 11 & $\begin{array}{l}\text { Пшеничнюк, } \\
\text { 1983. Табл. XV, } 8\end{array}$ & $\begin{array}{l}\text { Рис. } 4,32 \\
\text { (рисунок автора) }\end{array}$ \\
\hline 105. & \begin{tabular}{|l} 
Бишунгарово \\
курган 3 \\
погребение 6
\end{tabular} & $\begin{array}{l}\text { III-II вв. } \\
\text { до.н.э. }\end{array}$ & 11 & $\begin{array}{l}\text { Пшеничнюк, } \\
\text { 1983. Табл. XV, } 8\end{array}$ & $\begin{array}{l}\text { Рис. } 4,32 \\
\text { (рисунок автора) }\end{array}$ \\
\hline 106. & \begin{tabular}{|l} 
Бишунгарово \\
курган 5 \\
погребение 3 \\
\end{tabular} & $\begin{array}{l}\text { III-II вв. } \\
\text { до.н.э. }\end{array}$ & 9 & $\begin{array}{l}\text { Пшеничнюк, } \\
\text { 1983. Табл. XVII, } 7\end{array}$ & $\begin{array}{l}\text { Рис. } 4,33 \\
\text { (рисунок автора) }\end{array}$ \\
\hline
\end{tabular}




\begin{tabular}{|c|c|c|c|c|c|}
\hline 107. & \begin{tabular}{|l} 
Бишунгарово \\
курган 11 \\
погребение 4 \\
\end{tabular} & $\begin{array}{l}\text { III-II вв. } \\
\text { до.н.э. }\end{array}$ & 16 & $\begin{array}{l}\text { Пшеничнюк, } \\
\text { 1983. Табл. XIX, } 5\end{array}$ & Рис. 4, 34 \\
\hline 108. & \begin{tabular}{|l} 
Бишунгарово \\
курган 11 \\
погребение 7
\end{tabular} & $\begin{array}{l}\text { III-II вв. } \\
\text { до.н.э. }\end{array}$ & 10 & \begin{tabular}{|l|} 
Пшеничнюк, \\
1983. Табл. XIX, 9
\end{tabular} & Рис. 4,35 \\
\hline 109. & \begin{tabular}{|l} 
Бишунгарово \\
курган 11 \\
погребение 7 \\
\end{tabular} & $\begin{array}{l}\text { III-II вв. } \\
\text { до.н.э. }\end{array}$ & 10 & $\begin{array}{l}\text { Пшеничнюк, } \\
\text { 1983. Табл. XIX, } 9\end{array}$ & Рис. 4, 35 \\
\hline 110. & $\begin{array}{l}\text { Бишунгарово } \\
\text { курган } 11 \\
\text { погребение } 9\end{array}$ & $\begin{array}{l}\text { III-II вв. } \\
\text { до.н.э. }\end{array}$ & 12 & \begin{tabular}{|l|} 
Пшеничнюк, \\
1983. Табл. XXI, 2
\end{tabular} & Рис. 4,36 \\
\hline 111. & \begin{tabular}{|l} 
Бишунгарово \\
курган 11 \\
погребение 9 \\
\end{tabular} & $\begin{array}{l}\text { III-II вв. } \\
\text { до.н.э. }\end{array}$ & 12 & $\mid$\begin{tabular}{|l} 
Пшеничнюк, \\
1983. Табл. XXI, 2
\end{tabular} & Рис. 4, 36 \\
\hline 112. & \begin{tabular}{|l} 
Бишунгарово \\
курган 19 \\
погребение 4 \\
костяк 1 \\
\end{tabular} & $\begin{array}{l}\text { III-II вв. } \\
\text { до.н.э. }\end{array}$ & 10 & \begin{tabular}{|l|} 
Пшеничнюк, \\
1983. табл. XXIV, 2
\end{tabular} & $\begin{array}{l}\text { Рис. } 4,37 \\
\text { (рисунок автора) }\end{array}$ \\
\hline 113. & \begin{tabular}{|l} 
Бишунгарово \\
курган 19 \\
погребение 4 \\
костяк 2 \\
\end{tabular} & $\begin{array}{l}\text { III-II вв. } \\
\text { до.н.э. }\end{array}$ & 9 & \begin{tabular}{|l|} 
Пшеничнюк, \\
1983. табл. XXIV, 9
\end{tabular} & $\begin{array}{l}\text { Рис. } 4,38 \\
\text { (рисунок автора) }\end{array}$ \\
\hline 114. & $\begin{array}{l}\text { Старые Киишки } \\
\text { курган } 11 \\
\text { погребение } 2 \\
\end{array}$ & $\begin{array}{l}\text { III-II вв. } \\
\text { до.н.э. }\end{array}$ & 10 & $\begin{array}{l}\text { Садыкова, } 1958 . \\
\text { Рис. } 145,5\end{array}$ & $\begin{array}{l}\text { Рис. } 4,39 \\
\text { (рисунок автора) }\end{array}$ \\
\hline 115. & $\begin{array}{l}\text { Старые Киишки } \\
\text { курган } 11 \\
\text { погребение } 3 \\
\end{array}$ & $\begin{array}{l}\text { III-II вв. } \\
\text { до.н.э. }\end{array}$ & 11 & $\begin{array}{l}\text { Садыкова, } 1958 . \\
\text { Рис. } 145,7\end{array}$ & $\begin{array}{l}\text { Рис. } 4,40 \\
\text { (рисунок автора) }\end{array}$ \\
\hline 116. & $\begin{array}{l}\text { Старые Киишки } \\
\text { курган } 11 \\
\text { погребение } 16\end{array}$ & $\begin{array}{l}\text { III-II вв. } \\
\text { до.н.э. }\end{array}$ & 9 & $\begin{array}{l}\text { Садыкова, } 1962 . \\
\text { Табл. IV, } 11\end{array}$ & $\begin{array}{l}\text { Рис. } 4,41 \\
\text { (рисунок автора) }\end{array}$ \\
\hline 117. & $\begin{array}{l}\text { Старые Киишки } \\
\text { курган } 13 \\
\text { погребение } 5\end{array}$ & $\begin{array}{l}\text { III-II вв. } \\
\text { до.н.э. }\end{array}$ & 10 & $\begin{array}{l}\text { Садыкова, } 1962 . \\
\text { Табл. VI, } 15\end{array}$ & Рис. 4,42 \\
\hline 118. & $\begin{array}{l}\text { Старые Киишки } \\
\text { курган } 13 \\
\text { погребение } 12\end{array}$ & $\begin{array}{l}\text { III-II вв. } \\
\text { до.н.э. }\end{array}$ & 12 & $\begin{array}{l}\text { Садыкова, } 1962 . \\
\text { Табл. VIII, } 2\end{array}$ & Рис. 4, 43 \\
\hline 119. & \begin{tabular}{|l} 
Старые Киишки \\
курган 14 \\
погребение 7
\end{tabular} & $\begin{array}{l}\text { III-II вв. } \\
\text { до.н.э. }\end{array}$ & 11 & $\begin{array}{l}\text { Садыкова, } 1958 . \\
\text { Рис. } 145,6,8\end{array}$ & $\begin{array}{l}\text { Рис. } 4,44 \\
\text { (рисунок автора) }\end{array}$ \\
\hline 120. & $\begin{array}{l}\text { Старые Киишки } \\
\text { курган } 14 \\
\text { погребение } 7\end{array}$ & $\begin{array}{l}\text { III-II вв. } \\
\text { до.н.э. }\end{array}$ & 12 & $\begin{array}{l}\text { Садыкова, } 1958 . \\
\text { Рис. 145, 6,8 }\end{array}$ & $\begin{array}{l}\text { Рис. } 4,44 \\
\text { (рисунок автора) }\end{array}$ \\
\hline 121. & \begin{tabular}{|l} 
Старые Киишки \\
курган 14 \\
погребение 14 \\
\end{tabular} & $\begin{array}{l}\text { III-II вв. } \\
\text { до.н.э. }\end{array}$ & 12 & $\begin{array}{l}\text { Садыкова, } 1962 . \\
\text { Табл. IX, } 25\end{array}$ & $\begin{array}{l}\text { Рис. } 4,45 \\
\text { (рисунок автора) }\end{array}$ \\
\hline
\end{tabular}




\begin{tabular}{|c|c|c|c|c|c|}
\hline 122. & $\begin{array}{l}\text { Старые Киишки } \\
\text { курган } 15 \\
\text { погребение } 10\end{array}$ & $\begin{array}{l}\text { III-II вв. } \\
\text { До.н.э. }\end{array}$ & 17 & $\begin{array}{l}\text { Садыкова, } \\
\text { Васильев, } 2001 . \\
\text { С.59 }\end{array}$ & $\begin{array}{l}\text { Рис. } 4,46 \\
\text { (рисунок автора) }\end{array}$ \\
\hline 123. & $\begin{array}{l}\text { Старые Киишки } \\
\text { курган } 18 \\
\text { погребение } 9\end{array}$ & $\begin{array}{l}\text { III-II вв. } \\
\text { до.н.э. }\end{array}$ & 18 & $\begin{array}{l}\text { Садыкова, } \\
\text { Васильев, } 2001 . \\
\text { С.60 }\end{array}$ & $\begin{array}{l}\text { Рис. } 4,47 \\
\text { (рисунок автора) }\end{array}$ \\
\hline 124. & $\begin{array}{l}\text { Старые Киишки } \\
\text { курган } 18 \\
\text { погребение } 27\end{array}$ & $\begin{array}{l}\text { III-II вв. } \\
\text { до.н.э. }\end{array}$ & 12 & $\begin{array}{l}\text { Садыкова, } 1958 . \\
\text { Рис. 188, } 3\end{array}$ & $\begin{array}{l}\text { Рис. } 4,48 \\
\text { (рисунок автора) }\end{array}$ \\
\hline 125. & $\begin{array}{l}\text { Якутово II } \\
\text { курган } 3 \\
\text { погребение } 2\end{array}$ & $\begin{array}{l}\text { III-II вв. } \\
\text { до.н.э. }\end{array}$ & 12 & $\begin{array}{l}\text { Агеев, Рутто, } \\
\text { 1984. С.42, рис. } \\
3,5\end{array}$ & Рис. 4,49 \\
\hline 126. & $\begin{array}{l}\text { Чкаловский } \\
\text { курган } 4 \\
\text { погребение } 10\end{array}$ & $\begin{array}{c}\text { II-I вв. до } \\
\text { н.э. }\end{array}$ & 15 & $\begin{array}{l}\text { Воронова, } \\
\text { Порохова, } 1992 . \\
\text { С.250, рис. } 8,11\end{array}$ & $\begin{array}{l}\text { Рис. } 5,1 \\
\text { (рисунок автора) }\end{array}$ \\
\hline 127. & $\begin{array}{l}\text { Жарсуат I } \\
\text { курган } 2 \\
\text { погребение } 4\end{array}$ & $\begin{array}{c}\text { II-I вв. до } \\
\text { н.э. }\end{array}$ & 8 & $\begin{array}{l}\text { Железчиков, } \\
\text { 1998. Рис. 43, } 11\end{array}$ & Рис. 5, 2 \\
\hline 128. & $\begin{array}{l}\text { Жарсуат I } \\
\text { курган } 2 \\
\text { погребение } 4\end{array}$ & $\begin{array}{c}\text { II-I вв. до } \\
\text { н.э. }\end{array}$ & 8 & $\begin{array}{l}\text { Железчиков, } \\
\text { 1998. Рис. 43, } 11\end{array}$ & Рис. 5, 2 \\
\hline
\end{tabular}




\section{В.Н. Мышкин}

\section{O дате кургана 3 могильника Филипповка I*}

Резюме. Статья посвящена анализу материалов, полученных при исследовании кургана 3 могильника Филипповка I. Цель исследования - определить хронологию центрального захоронения кургана. Анализ сочетания различных типов бытовых предметов, вооружения, прежде всего, конской амуниции, сопоставление принадлежностей конского снаряжения с аналогичными находками на территории Северного Причерноморья и Северного Кавказа позволили предложить для центрального погребения узкую дату, которая, вероятно, укладывается в рамки середины-третьей четверти IV в. до н.э.

Ключевые слова: ранний железный век, Южное Приуралье, кочевники, курган, погребальный инвентарь, хронология.

\section{V.N. Myshkin}

\section{About the date of the mound 3 of the Filippovka I burial ground}

Abstract. The article is devoted to the analysis of materials obtained during the study of the mound 3 of the Filippovka I burial ground. The purpose of the study was to determine the time of the central burial of this mound. An analysis of the combination of various types of household items, weapons, and especially horse harness, as well as a comparison of horse equipment with similar finds on the territory of the Northern Black Sea Region and the North Caucasus, * Работа выполнена при поддержке Российского научного бонда, проект №18-
18-00137 
made it possible to propose a narrow date for the central burial, which probably fits into the middle-third quarters of the 4th century BC.

Keywords: the Early Iron Age, Southern Urals, nomads, barrow, funerary equipment, chronology.

Уникальность могильника Филипповка I делает необходимым дальнейшее исследование материалов этого памятника, включая разработку вопросов его хронологии, в том числе уточнение периода функционирования некрополя и времени возведения его отдельных курганов. Время функционирования этого некрополя определялось началом IV в. до н.э. (Пшеничнюк, 2012. C. 87), второй половиной IV в. до н.э. (Васильев, 2004. С. 153-172); второй половиной V-IV в. до н.э. (Яблонский, 2008. С. 262); периодом от рубежа V-IV вв. до н.э. до третьей четверти IV вв. до н.э. (Трейстер, Яблонский, 2012. С. 284). Курган 1 было предложено датировать V-IV вв. до н. э. (Королькова (Чежина), 1992. С. 98-99). С этой точки зрения интерес представляет курган 3, в котором найдены импортные предметы, позволяющие предложить для этого комплекса достаточно узкую дату. Детали сбруи, обнаруженные у подножия кургана, рассматриваются как более поздние по отношению к остальным комплексам могильника. Они свидетельствуют о верхней границе даты некрополя, не исключающей второй половины IV в. до н.э. (Канторович, Яблонский, 2009. С. 82-83). Эти обстоятельства послужили причиной анализа материалов именно этого кургана для определения времени его совершения.

В центральной могиле 1 кургана обнаружены украшения, наконечники стрел, железный чешуйчатый панцирь, меч, зеркало, пряслице, бусы, нож, костяное орудие, крючок, костяная статуэтка воина, сидящего на коне (рис. 1, 3-4; 2, 1-79; 3, 1-5). В пределах насыпи к Ю3 от центральной могилы на уровне древнего горизонта 
обнаружено скопление костей лошади, рядом на этом же уровне лежали предметы сбруи (рис. 1, 1, 6-27). К С3 от центральной могилы располагалось впускное погребение 2, которое было совершено, очевидно, после того, как перестало функционировать погребение 1. Впускное захоронение содержало сосуд, котел и обойму (Пшеничнюк, 2012. С. 30-37. Рис. 54-71). На основании морфологических и технологических признаков среднеазиатский круговой красноглиняный сосуд (рис. 1,2 ) датирован временем не позднее конца IV в. до н.э. (Болелов, 2012. С. 217). Таким образом, впускное погребение 2 фиксирует время прекращения функционирования центрального захоронения 1, которое наступило не позже конца IV в. до н.э.

Что касается вещей из погребения 1 , то они дают широкую дату. Меч (рис. 1,4$)$ со слегка изогнутым навершием и перекрестьем в виде изогнутого под тупым углом бруска (Пшеничнюк, 2012. С. 34. Рис. 66) относится к «переходному типу», время бытования которого первоначально ограничивали IV в. до н.э. (Мошкова, 1963. С. 33-34). Сейчас начало их использования относят ко второй половине V в. до н.э. (Таиров и др., 2008. С. 143-144).

Бронзовое зеркало (рис. 1, 3) с диском, имеющим широкий уплощенный валик по краю, и длинной боковой ручкой (Пшеничнюк, 2012. С. 34) имеет аналогии среди зеркал, найденных в южноуральских комплексах как V в. до н.э., так и IV в. до н.э.: кургане 7 могильника Бис-Оба и кургане у с. Ак-Булак (Смирнов, 1964. С. 153). Этот тип зеркал, по мнению А.С. Скрипкина, встречается вплоть до рубежа IV-III вв. до н. э. (Скрипкин, 1990. С. 150).

Бронзовые наконечники стрел из погребения 1 (рис. 2, 1-60) разнотипные втульчатые: пулевидные, трехгранные, с внутренней и выступающей втулкой типов $3,4,14$, и трехлопастные, с внутренней и выступающей втулкой типов $6,10,12,13$, длительное время (с VI по IV в. до н. э., некоторые - по II в. до н.э.) использовавшиеся кочевниками Южного Приуралья. Большин- 
ство из них имеет небольшие размеры и треугольные головки, что становится характерным для наконечников с IV в. до н.э. (Смирнов, 1961. С. 46, 49, 50-52, 56). Хронология железных наконечников стрел не является в достаточной степени разработанной, что не позволяет использовать их для датировки комплекса.

Среди конского снаряжения, найденного в кургане, для определения даты возведения использованы следующие предметы.

Уздечная бляшка в виде головы волка (рис. 1, 22). Основная масса датируемых изображений этого типа ограничена рамками 2-й половины V-IV в. до н.э. (Канторович, Маслов, 2017. Рис. 14. С. 116-117).

Подвеска (рис. 1, 26) на наносный или налобный ремень (Пиеничнюк, 2012. С. 32. Рис. 57, 14) в виде головы «оленекозла» по (терминологии А.Р. Канторовича) сходна с серией находок в Прикубанье, лесостепном Поднепровье, Абхазии и на Нижнем Дону. Аналогичные детали узды найдены в памятниках, которые датированы временем в пределах IV в. до н.э.: у Агудзеры, на поселении Ахул-абаа, (Воронов, 1975. С. 231; 1991. С. 230; Эрлих, 2004. С. 172) в Шолоховском кургане (Максименко и др., 1984. С. 140), Карагодеуашхе (Лаппо-Данилевский, Мальмберг, 1884. С. 191; Артамонов, 1966. С. 77; Алексеев и др., 1991. С. 86), кургане 1 некрополя Тенгинского II городища (Эрлих, 2002, С. 7-17; 2004. С. 170. Рис 5, 12), Елизаветинских курганах 4 и 7 (Галанина, 2005. С. 98, $104,107$. Табл. $4,4,5,8,10,11)$. Следует присоединиться к мнению, что филипповская подвеска была изготовлена под влиянием прикубанских культурных традиций или поступила из Прикубанья не ранее начала IV в. до н.э. (Канторович, Яблонский, 2009. С. 77).

Две пары Г-образных псалиев (рис. 1, 9-10) со щитками в виде ажурной пальметки - стилизованной лапы хищной птицы, когти которой в одном случае трансформированы в головы птиц, в другой в головы зверей (Пшеничнюк, 2012. С. 32. Рис. 56, 4, 5). Ближайшие 
аналогии этим экземплярам найдены в кургане 1 у станицы Кужорской (Шедевры..., 1987. С. 86, 90, 92. Кат. №№22, 24), датированном 1-3 четвертями IV в. до н.э. (Канторович, 2015. С. 140), елизаветинском кургане 4, период сооружения которого - 1 четверть IV в. до н.э. (Галанина, 2005. Рис. 3, 7. С. 98). Аналогичные псалии найдены в погребениях 224, 159, 236, 394 Прикубанского могильника. Погребение 224 датировано 60-40 гг, остальные - 2 четвертью IV в. до н. э. (Лимберис, Марченко, 2018. С. 101-102. Рис. 2, 1-2, 3, 1-2; 5, 4-5; 6, 2-3).

Бронзовый наконечник псалия (рис. 1, 24), выполненный в виде стержня, завершающегося скульптурным схематичным изображением головы хищного животного (пантеры?), которая расположена под прямым углом к продольной оси наконечника (Пшеничнюк, 2012. С. 32. Рис. 57, 10). Наиболее близкой аналогией этой находке являются бронзовые наконечники псалиев с изображением головки пантеры из курганов 1 и 2 некрополя Тенгинского II городища, а также изображения на псалиях, найденных М.Б. Барамидзе при раскопках Гюэноса. Указанные курганы датированы второй половиной IV в. до н.э., а предметы узды из Гюэноса - серединой-второй половиной IV в. до н. э. (Эрлих, 2004, с. 159, 165, 170. Рис. 1, 2-3; 5, 10, 12).

Четыре бронзовых двудырчатые псалия (рис. 1, 6-7) в виде прямых стержней, окончания которых не имеют какого-либо дополнительного оформления, относятся к типу, который использовался южноуральскиими кочевниками с конца VI по IV в. до н.э. (Смирнов, Петренко, 1963. Табл. 16, 11; 1964. С. 50; Кадырбаев, Курманкулов, 1976. С. 144. Рис. 5, 2; Боталов, Таиров, 1996. С. 129, 134-135. Рис. 9, 7; Пшеничнюк, 1995. С. 85. Рис. 14, 16; 11, 7; Сиротин, 2016. С. 259; Сиротин, 2015. С. 250, 252. Рис. 3, 6).

Налобник (рис. 1, 23) в виде фигуры, которая интерпретирована как изображение копытного животного с подогнутой задней ногой и вывернутой передней, имеет аналогии среди 
предметов сбруи из памятников Северного Кавказа. Особенности композиционного решения этого налобника сближает его с находкой из кургана 2 Уляпского могильника, отнесенного к первой половине IV в. до н. э., а схематизм и геометричность - с налобником из Елизаветинского кургана 7, датированного временем не позднее 3 четверти IV в. до н.э., позволяет датировать его 2-3 четвертями IV в. до н.э. (Канторович, Яблонский, 2009. С. 78).

Пластинчатый налобник (рис. 1, 20) в виде припавшего на передние лапы хищника с вывернутой задней частью (Пшеничнюк, 2012. С. 32. Рис. 56, 6). Близкими аналогиями данному предмету являются налобники из кургана 2 могильника Уляп (1 половина IV в. до н. э.), кургана 2 некрополя Тенгинского II городища, жертвенного комплекса 1 из раскопок 1985 г. на Гюэносе, отнесенных к середине - 2 половине IV в. до н.э. (Эрлих, 2004. С. 166-167, 170. Рис. 3, 1-4), погребений 33 и 224 Прикубанского могильника, датированных 2 четвертью и 60-40 гг. IV в. до н.э. соответственно (Лимберис, Марченко, 2018. С. 100-101. Рис. 1, 1; 5, 1). Уляпский курган 2 датирован первой половиной IV в. до н.э. (Эрлих, 2004. С. 170). Филипповский экземпляр рассматривается как подражание налобникам типа уляпского и тенгинского (Канторович. Яблонский, 2009. С. 78). Это свидетельствует в пользу его датирования временем в пределах середины-второй половины IV в. до н.э.

Бронзовая налобная подвеска (рис. 1,21) в виде птицы (Пшеничнюк, 2012. Рис. 57, 11) сходна с налобником из кургана 5 могильника Колбино I на Среднем Дону (Савченко, 2004. С. 56, 89. Рис. 25, 1) и может быть отнесена к середине-второй половине IV в. до н.э.

Наиболее близкой аналогией двудырчатому стержневидному бронзовому псалию с окончаниями в виде круглых лопастей (рис. 1, 8) являются слегка изогнутые биметаллические $\mathrm{S}$-видные псалии с окончаниями в виде округлых лопастей из кургана 1 некрополя Тенгинского II городища, датированного второй половиной IV в. до н.э. (Эрлих, 2002. Рис. 3, 7). 
Аналогиями длинной ворворке (рис. 1, 16) с вогнутыми стенками (Пшеничнюк, 2012. С. 32. Рис. 57, 3) являются находки из погребения 2 кургана 6 могильника Переволочан I (Пшеничнюк, 1995. С. 69. Рис. 5, 6), занимающего в этом памятнике промежуточную хронологическую позицию между комплексами, сооруженными не позднее второй половины V в. до н.э. - рубежа V-IV вв. до н.э. и второй половины IV в. до н.э. (Сиротин, 2016. С. 261). У скифов Северного Причерноморья время использования ворворок с вогнутыми стенками (группа II-1) приходится на вторую четверть V в. до н. э. - рубеж V-IV вв. до н.э. (Алексеев, 2003, с. 214-215). Такие ворворки встречены в курганах V в. до н.э.: № 398 у с. Журовка, № 4 у с. Берестняги (Петренко, 1967. Табл. 32, 23-24. С. 92-93), № 3 в ур. Стайкин Верх, Старшей могиле (Ильинская, 1968. Табл. V, 10;), в Завадской Могиле (Мозолевский, 1980. Рис. 37, 9; 38, 5; 41, 11-13 Алексеев, 2003. С. 259), №o 1 (гробница 14) и 24 некрополя Нимфея (Силантьева, 1959. Рис. 37, 10; 47, 11. С. 71, 83). Ворворки достаточно сложно отнести к числу предметов конского снаряжения, которые могли очень долго храниться и использоваться кочевниками. Наличие длинной ворворки в наборе филипповского кургана 3 свидетельствует в пользу того, что диапазон даты рассматриваемого погребального комплекса, определенный по другим, более поздним предметам, следует ограничить временем, наиболее приближенным к рубежу V-IV вв. до н.э.

Подводя итоги, необходимо отметить, что курган 3 могильника Филипповка I был возведен в IV в. до н.э. Сочетание таких предметов конского снаряжения, как Г-образные псалии с ажурными пластинчатыми окончаниями (рис. 1, 9-10), окончаниями в виде округлых лопастей (рис. 1, 8), наконечник псалия в виде головки пантеры (рис. 1, 24), пластинчатые налобники (рис. 1, 20-23), подвеска в виде птицы (рис. 1, 21) позволяет предположить, что дата возведения этого кургана приходится на середину-третью четверть IV в. до н.э. (рис. 4). 


\section{ЛИТЕРАТУРА}

Алексеев Ю.А., 2003. Хронография Европейской Скифии VII-IV веков до н.э. СПб.: Изд-во Гос. Эрмитажа, 416 с.

Алексеев А.Ю., Мурзин В.Ю., Ролле Р., 1991. Чертомлык. Скифский царский курган IV в. до н.э. Киев.: Наукова Думка, 416 с.

Артамонов М.И., 1966. Сокровища скифских курганов в собрании Государственного Эрмитажа. Прага - Л.: «Артия», «Советский художник», 120 с.

Болелов С.Б., 2012. Среднеазиатская керамика в памятниках кочевников Южного Приуралья // Влияние ахеменидской культуры в Южном Приуралье (V-III вв. до н.э.) / Ред. М.Ю. Трейстер, Л.Т. Яблонский. Том 1. М.: Изд-во Таус. С. 208-219.

Боталов С.Г., Таиров А.Д., 1996. Памятники раннего железного века в окрестностях села Варна // Материалы по археологии и этнографии Южного Урала: Тр. музея-заповедника Аркаим. Челябинск: Каменный пояс. С. 117-138.

Васильев В.Н., 2004. К хронологии раннепрохоровского комплекса // Уфимский археологический вестник. Вып. 5. Уфа: Гилем. С. 153-172.

Воронов Ю.Н., 1975. Вооружение древнеабхазских племен в VI-I вв. до н.э. // Скифский мир / Ред. А.И. Тереножкин . Киев: Наукова думка. С. 218-234.

Воронов Ю.Н., 1991. Новые материалы античной эпохи из окрестностей Диоскурии // СА. №1. С. 225-234.

Галанина Л.К., 2005. Кубанское уздечное снаряжение IV в. до н. э. (по материалам Елизаветинского кургана, раскопанного Н.И. Веселовским в 1913 г.) // Археологический сборник Государственного Эрмитажа. Вып. 37. СПб. Изд-во Гос. Эрмитажа. С. 97-108.

Ильинская В.А., 1968. Скифы днепровского лесостепного Левобережья (курганы Посулья). Киев: Наукова думка. 268 с.

Кадырбаев М.К., Курманкулов Ж., 1976. Захоронение вои- 
нов савроматского времени на левобережье р. Илек // Прошлое Казахстана по археологическим источникам / Ред. К.А. Акишев. Алма-Ата: Наука Казахской ССР, С. 137-156.

Канторович А.Р., 2015. Образы синкретических существ в восточноевропейском скифском зверином стиле: классификация, типология, хронология, иконографическая динамика // Исторические исследования. № 3. С. 113-218.

Канторович А.Р., Яблонский Л.Т., 2009. О северопричерноморских и северокавказских параллелях изображениям в скифо-сибирском зверином стиле на предметах из Филипповских курганов // Нижневолжский археологический вестник. Вып. 10. Волгоград: Изд-во ВолГУ. С. 73-99.

Канторович А.Р., Маслов В.Е, 2017. Могильник Новозаведенное-III как свидетельство пребывания скифов в Центральном Предкавказье в конце V - IV в. до н.э. // Исторические исследования. №8. Код доступа http://www.historystudies.msu.ru/ojs2/ index.php/ISIS/article/view/141/347

Королькова (Чежина) Е.Ф., 1992. О датировке Филипповского кургана // Вторые исторические чтения памяти Михаила Петровича Грязнова. Часть II / Отв. ред. В.И. Матющенко. Омск: Изд-во Омского гос. ун-та. С. 97-99.

Лаппо-Данилевский А., Мальмберг В., 1894. Древности Южной России Курган Карагодеуашх (МАР, №13). СПб. 192 с.

Лимберис Н.Ю., Марченко И.И., 2018. Хронология погребений с конской упряжью в зверином стиле из Прикубанского могильника // Вестник ВолГУ. Серия 4, История. Регионоведение. Международные отношения. 2018. Т. 23. № 3. С. 99-113. DOI: https://doi.org/10.15688/jvolsu4.2018.3.9

Максименко В.Е., Смирнов К.Ф. Горбенко А.А., Лукьяшко С.И., 1984. Курган у пос. Шолоховский. Богатые раннесарматские комплексы правобережья Дона. Приложение // Смирнов 
К.Ф. Сарматы и утверждение их политического господства в Скифии. М.: Наука. С. 124-141.

Мозолевский Б.М., 1980. Скифские курганы в окрестностях г. Орджоникидзе на Днепропетровщине // Скифия и Кавказ / Ред. А.И. Тереножкин. Киев: Наукова думка. С.70-154.

Мошкова М.Г., 1963. Памятники прохоровской культуры (САИ, Д1-10) / Ред. Б.А. Рыбаков. М.: АН СССР. 56 с.

Петренко В.Г., 1967. Правобережье Среднего Приднепровья в V-III вв. до н.э. (САИ, Д1-4) / Ред. Б.А. Рыбаков. М.: Наука. 180 с.

Пшеничнюк А.Х., 1995. Переволочанский могильник // Курганы кочевников Южного Урала / Ред. Б.Б. Агеев. Уфа: Гилем. С. 62-96.

Пшеничнюк А.Х., 2012. Филипповка: Некрополь кочевой знати IV века до н.э. на Южном Урале. Уфа: ИИЯЛ УНЦ РАН. 280 с.

Савченко Е.И., 2004. Могильник скифского времени «Терновое I - Колбино I» на Среднем Дону (погребальный обряд) // Археология Среднего Дона в скифскую эпоху: труды Потуданской археологической экспедиции ИА РАН / Ред. В.И. Гуляев. М.: Институт археологии РАН. С. 53-143.

Силантьева Л.Ф., 1959. Некрополь Нимфея // Некрополи Боспорских городов (МИА, №69) / Ред. В.Ф. Гайдукевич. М.-Л.: АН CCCP. С. 5-107.

Сиротин C.B., 2015. Предметы конской сбруи из насыпей курганов ранних кочевников Южного Урала (по материалам раскопок 2008-2013 годов) // Этнические взаимодействия на Южном Урале: материалы VI Всероссийской научной конференции / Ред. А.Д. Таиров. Челябинск. С. 247-255.

Сиротин С.В. 2016. Об относительной хронологии и датировке Переволочан I // Константин Фёдорович Смирнов и современные проблемы сарматской археологии. Проблемы сарматской археологии и истории / Ред. Л.Т. Яблонский, Л.А. Краева. Оренбург: ОГПУ. С. 253-264 
Скрипкин А.С., 1990. Азиатская Сарматия. Проблемы хронологии и её исторический аспект // Саратов: Изд-во Саратовского ун-та. $300 \mathrm{c.}$

Смирнов К.Ф., 1961. Вооружение савроматов (МИА, № 101). М.: Изд-во АН СССР, 1961. 163 с.

Смирнов К.Ф., 1964. Савроматы. Ранняя история и культура сарматов. М: Наука. 380 с.

Смирнов К.Ф., Петренко В.Г., 1963. Савроматы Поволжья и Южного Приуралья (САИ, Д1-9) / Ред. Б.А. Рыбаков. М.: АН CCCP, $40 \mathrm{c}$.

Таиров А.Д., Боталов С.Г., Плешанов М.Л., 2008. Исследования курганного могильника Кичигино в 2007 году (предварительные результаты) // Ранние кочевники Волго-Уральского региона: материалы междунар. науч. конф. «Ранние кочевники Южного Приуралья в свете новейших археологических открытий» / Ред. Л.Т. Яблонский. Оренбург, 21 -25 апреля 2008 г. Оренбург: ОГПУ. С. 139-145.

Трейстер М.Ю., Яблонский Л.Т. К вопросу об абсолютной дате могильника Филипповка I // Влияние ахеменидской культуры в Южном Приуралье (V-III вв. до н.э.) / Ред. М.Ю. Трейстер, Л.Т. Яблонский. Том 1. М.: Изд-во Таус, 2012. С. 282-284.

Шедевры древнего искусства Кубани. Каталог выставки. 1987. M., 188 c.

Эрлих В.Р., 2002. Новое меотское святилище в Закубанье // Историко-археологический альманах / Ред. Р.М. Мунчаев. Армавир-М.: Армавирский краеведческий музей. С. 7-17.

Эрлих B.P., 2004. Меотское святилище в Абхазии // ВДИ. №1. C. 158-172.

Эрлих B.P., 2010. Узда Колхиды и Центральной Грузии античной эпохи: к проблеме выделения традиций // Археология и палеоантропология евразийских степей и сопредельных территорий: ма- 
териалы и исследования по археологии России (МИАР, №13) / Ред. М.М. Герасимова, В.Ю. Малашев, М.Г. Мошкова. М.: Таус. С. 73-106.

Яблонский Л.Т., 2008. Новые раскопки Филипповского I могильника // Археология Восточно-Европейской степи. Вып. 6. Саратов: Научная книга. С. 253-268.

\section{СПИСОК СОКРАЩЕНИЙ}

АН СССР - Академия наук Союза советских Социалистических Респблик

ВДИ - Вестник древней истории

ВолГУ - Волгоградский государственный университет

ГЭ - Государственный Эрмитаж

ИА РАН - Институт археологии Российской академии наук ИИЯЛ УНЦ РАН - Институт истории, языка и литературы Уфимского

научного центра Российской академии наук

МАР - Материалы по археологии России

МИА - Материалы и исследования по археологии СССР.

МИАР -Материалы и исследования по археологии России.

ОГПУ - Оренбургский государственный педагогические университет

СА - Советская археология

САИ - Свод археологических источников: Археология СССР

СВЕДЕНИЯ ОБ АВТОРЕ.

Мышкин Владимир Николаевич, кандидат исторических наук, Самарский государственный социально-педагогический университет, Самара, Россия, e-mail: vnm59@bk.ru 


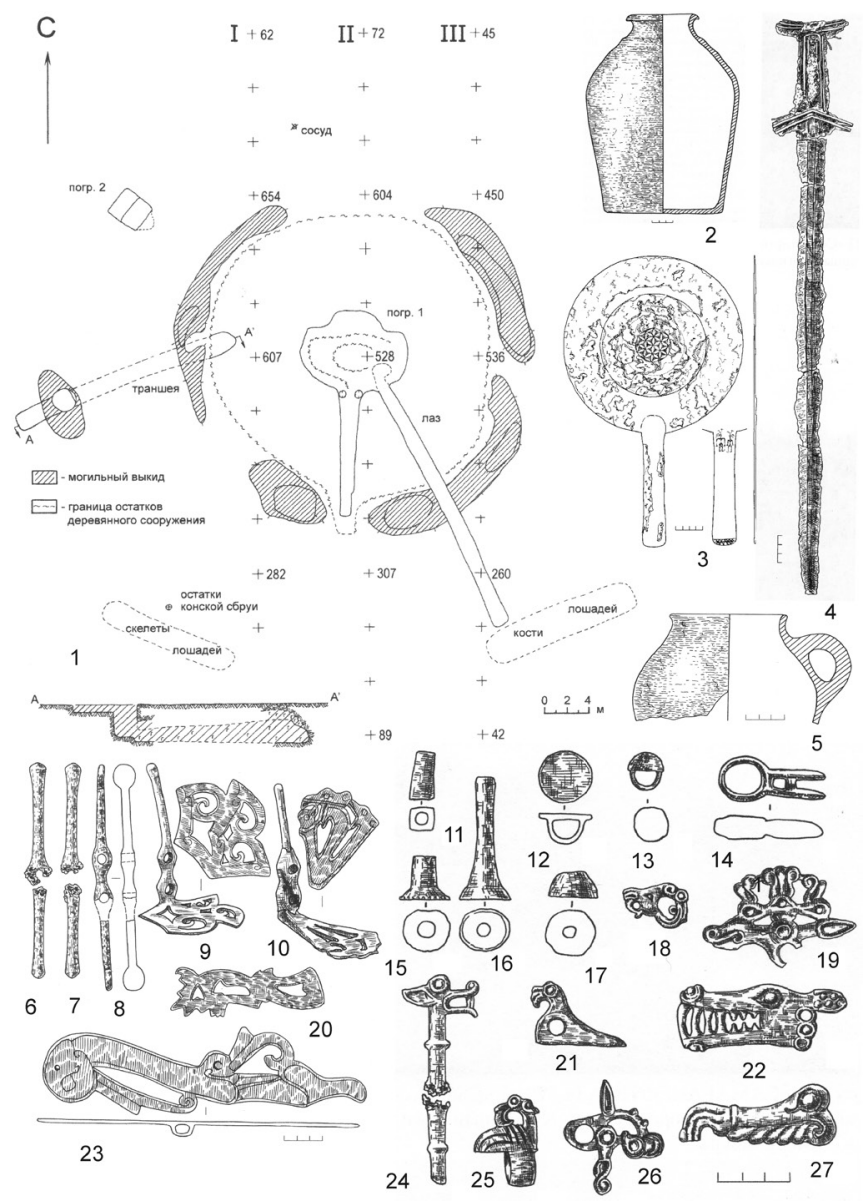

Рис. 1. Могильника Филипповка I. Курган 3. План и вещи из погребений 2 (2) и 1 (3-4), насыпи (5), захоронения коней (627). 1 - план кургана; 2, 5 - сосуды; 3 - зеркало; 4 - меч; 6-10 - псалии; 11, 15-17 - ворворки; 12-13, 18, 22, 27 - бляшки; 14 чумбурный блок; 19, 21, 25, 26 - подвески; 20, 23 - налобники; 24 - наконечники псалия (2, 5 - глина; 4 - железо; 3, 8-27 - бронза; 6-7 - бронза и железо). По: Пшеничнюк, 2012. Рис. 54, 56, 57, $58,65,66,71,1$ 


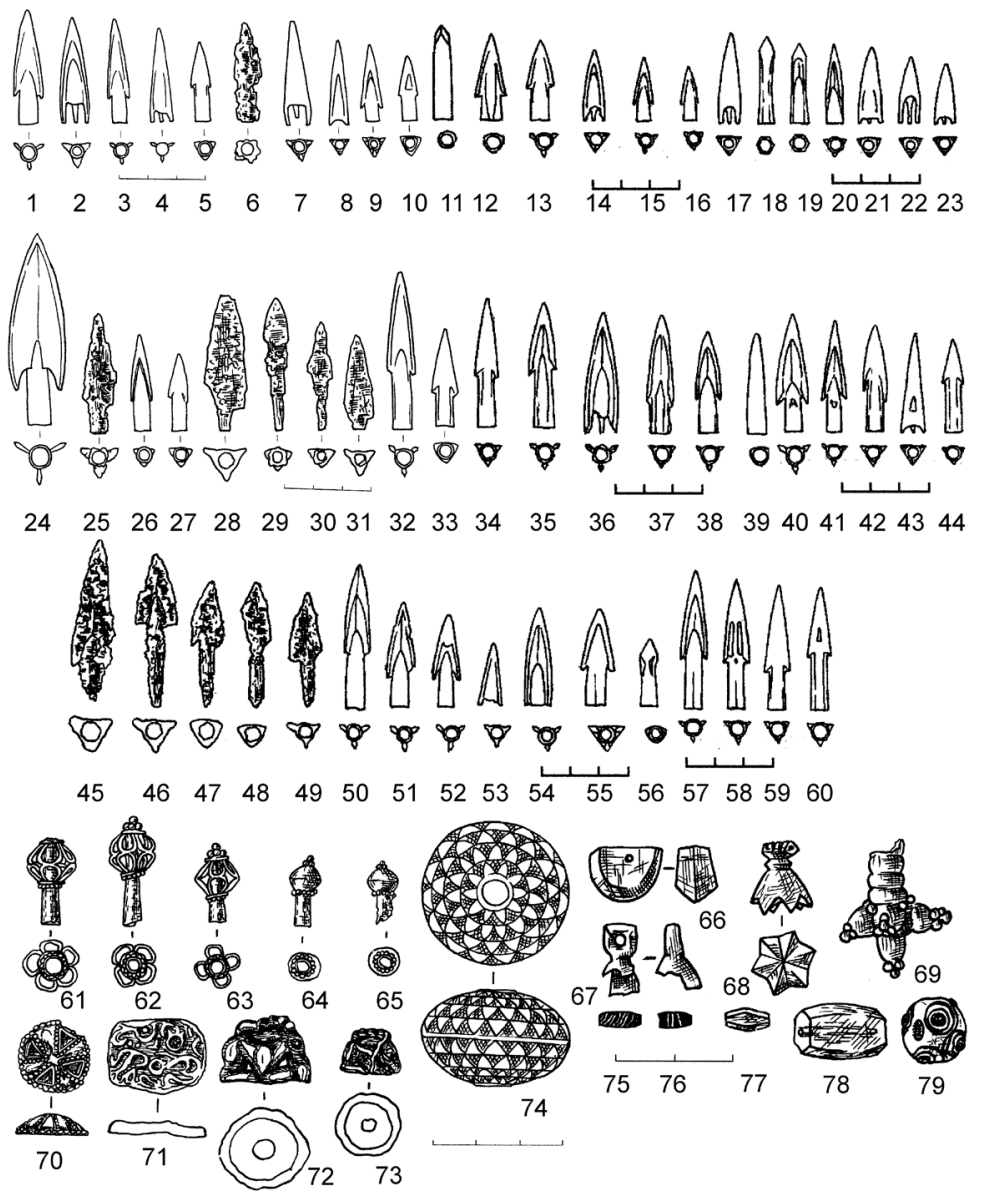

Рис. 2. Могильника Филипповка I. Курган 3. Вещи из погребения 1.

1-60 - наконечники стрел; 60-61 - навершия (наконечники); 66-69, 75-79 - бусы и пронизи; 70 - бляшка; 71 - накладка; $72-73$ - ворворки; 74 - пронизка $(1-5,7-24,26-27,32-44,50-60$ бронза; 6, 25, 28-31, 45-49 - железо; 61-65, 70-71 - золото; 72-73 серебро; 74 - смола и золото; 79 - стекло;). По: Пшеничнюк, 2012. Рис. 60, 61, 63, 68. 


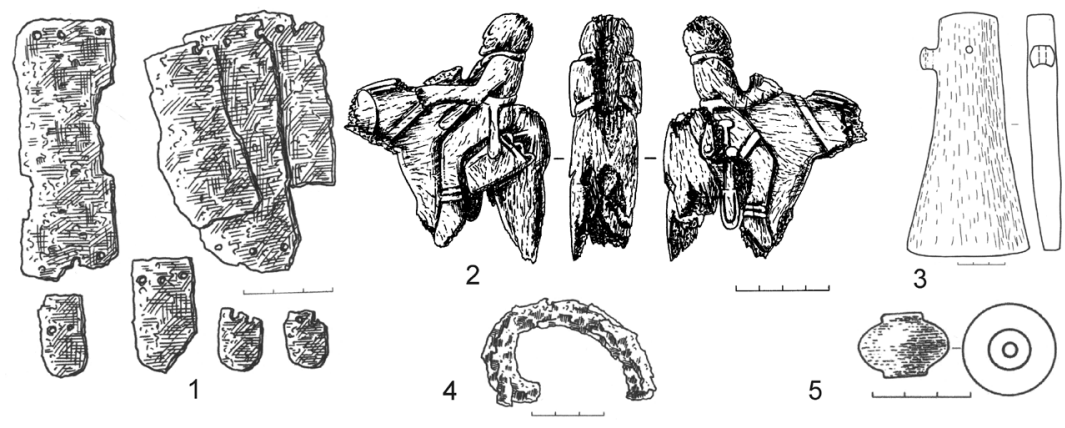

Рис. 3. Могильника Филипповка I. Курган 3. Вещи из погребения 1.

1 - пластины панциря; 2 - статуэтка; 3 - тесло; 4 - крючок; 5 - пряслице (1, 4 - железо; 2, 3 - кость; 5 - мел). По: Пшеничнюк, 2012. Рис. 64: 67, 5, 9, 10; 69. 


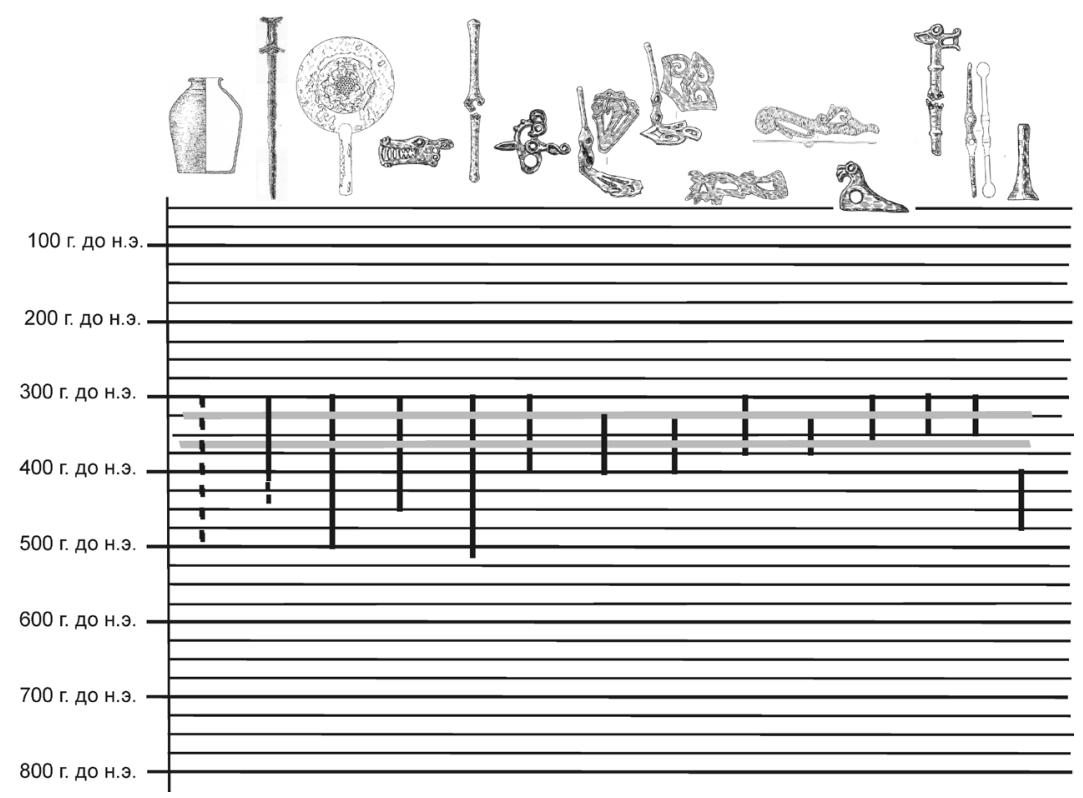

Рис. 4. Хронологическое распределение предметов из кургана 3 могильника Филипповка I. Серыми линиями отмечены вероятные границы даты кургана. 


\section{К.С. Окороков}

\section{Расшитые бисером рукава женского костюма из погребения 2 кургана 1 некрополя Филипповка 1}

Резюме. В статье рассматриваются нашивные украшения женской одежды из погребений курганного некрополя Филипповка I. Данный некрополь принадлежит родовой знати кочевников, обитавших в междуречье Урала и Илека в конце V-IV вв. до н.э. Анализируются в археологическом контексте предметы из драгоценных металлов, ассоциируемые с украшениями одежды ранних кочевников. Публикуется графическая реконструкция бисерной вышивки, украшающей рукава одного из предметов женской одежды, обнаруженных при расчистке погребения 2 кургана 1. Вышивка изображает расположенные друг за другом протомы оленей. Констатируется сходство предметов одежды в погребении 2 кургана1 и погребении 4 кургана 4, где массивными нашивками изображалось шествие кошачьих хищников. В обоих случаях это открытые снизу широкие рукава с декорированной каймой. В обоих случаях благодаря положению небольших нашивок вдоль костей рук реконструируются также платья с длинными узкими рукавами. Учитывая исключительную сохранность данных комплексов, а также обилие различных предметов, соотносимых с одеждой, представляется возможным реконструировать женские костюмы, обнаруженные в погребении 2 кургана 1 и погребении 4 кургана 4 могильника Филипповка I.

Ключевые слова: Южное Приуралье, Филипповка I, курганный могильник, ранние кочевники, детали одежды, женский костюм 


\section{K.S. Okorokov}

\section{Beaded sleeves of a female costume from burial 2 of mound 1 from the necropolis Filippovka 1}

Abstract. The article discusses the women's sewed on clothing decorations from the burials of the mound necropolis Filippovka I. This necropolis belongs to the nobility of nomads living in the interfluve area of the Urals and Ilek at the end of the 5th-4th centuries B.C.E. The precious metal items synonymous with the clothing decorations of the early nomads are analyzed from the perspective of archaeology. A graphic renovation of bead embroidery decorating the sleeves of one of the items of women's clothing found during clearing of burial 2 of mound 1, is published. The embroidery depicts deer protomas located one after another. The similarity of garments in burial 2 of mound 1 and burial 4 of mound 4, on which the procession of feline predators was depicted with large embroidered patches, is stated. In both cases, these are wide sleeves open from the bottom with a decorated border. In both cases, due to the position of the small stripes along the arm bones, dresses with long narrow sleeves are also renovated. Considering the exceptional integrity of these complexes, as well as the abundance of various items that are related to clothing, it turns out to be possible to renovate women's clothing found in burial 2 of mound 1 and burial 4 of mound 4 of the Filippovka I mound.

Key words: Southern Ural area, Filippovka I, mound, early nomads, details of clothing, women's clothing 
В 1986-1988 годах согласно плану экспедиционных исследований Института ИЯЛ БНЦ УрО АН СССР под руководством Пшеничнюка А.Х. был раскопан курган 1 Филипповского I курганного могильника. Были исследованы центральное дромосное погребение и два тайника, где, помимо прочих предметов из драгоценных металлов находились и золотые нашивки, которые украшали предметы одежды кочевой знати.

Всего в тайнике 2 находилось четыре разновидности золотых накладок, выполненных в технике выколотки по деревянной основе: 1) 20 накладок размером 8 на 6 см в виде фигур архаров в спокойной позе. Голова животного объёмная, спаяна из двух половин. На оборотной стороне припаяно 4 ушка для крепления. У 10 фигурок головы повернуты влево, у 10 - вправо; 2) 29 рельефных накладок с изображением сцены борьбы двух верблюдов, размером 5 на 4 см, с проделанными по углам отверстиями для пришивания; 3) 54 накладки с изображением фигуры лежащего оленя с подогнутыми ногами, прямоугольной формы. Размером 2,8 на 2 см, с четырьмя ушками для пришивания. На 20 накладках олень смотрит влево, на 34 - вправо. 4) 63 накладки с изображением головы хищника, размером 2 на 3 см, с двумя петлями для пришивания (Пщеничнюк, 2018. С. 16).

В силу ряда причин курган был раскопан не полностью, восточная пола оставалась неисследованной.

В июле-августе 2013 года Приуральской археологической экспедицией под руководством Яблонского Л.Т. было произведено доследование кургана 1 Филипповского I курганного могильника. Одним из результатов археологических работ стало выявление и исследование погребения 2. Длина перекрытого деревянным накатом погребения подпрямоугольной формы - 520 см, ширина 348 см, глубина - 436 см от уровня погребенной почвы, от уровня которой погребение и было произведено. Длинной осью было вы- 
тянуто меридионально. На дне могильной ямы находился скелет женщины, умершей в возрасте около 35 лет (Яблонскиц̆, 2014. С. 24).

Погребённая лежала на подстилке из органического материала растительного происхождения вытянуто на спине, головой на юг, лицом вверх (рис. 2, 3). Сопровождающий инвентарь сгруппирован в отдельные комплексы и расположен по всей площади могильной ямы. Находки, сделанные непосредственно на теле погребенной можно разделить на две группы:

1) ювелирные украшения, куда относятся золотые перстни на каждом пальце, браслеты из разнообразных бусин, золотые височные подвески-серьги.

2) украшения одежды, куда относятся золотые нашивки разных типов, позволяющие условно выявить различные типы одежды, а именно: платье с узкими рукавами; шаль, или накидка; элемент одежды с широкими открытыми рукавами, декорированными мелкими бусами и бисером (Яблонский, 2014, С. 55-62).

Платье: 1) 4 округлые нашивки размером 25 х 27 мм, расположенные вдоль грудины. На нашивках изображено свернувшееся копытное полорогое животное, предположительно сайгак. На обороте две петли для пришивания.

2) 26 подпрямоугольных нашивок с изображением сцены нападения кошачьего хищника на полорогое копытное животное. Размер нашивок 38 х 20 мм. На обратной стороне 4 петли для пришивания, расположенные по углам. Нашивки располагаются вдоль внешней стороны обеих рук, от плеча почти до запястья - 12 у левой руки, 14 у правой. Интересно, что головы обоих животных с нашивок с правой руки направлены вправо, а на нашивках с левой руки направлены влево. Положение этих нашивок позволяет реконструировать длинные узкие рукава одного из типов одежды погребенной, очевидно, платья. 
3) 2 пришивных украшения обшлагов узких рукавов рубахи или платья, выполненные из золота и сердоликовых бусин. (Аникеева, Яблонский, 2019. С. 14-15, 19). Подобным образом, на наш взгляд, можно интерпретировать и однотипные подвески в виде цепочек с бочонковидной бусиной вверху и головой животного внизу, из кургана 1, не публиковавшиеся вплоть до 2012 года (Фёдоров, 2012. С. 256. Рис. 14, 1).

Шаль: 4) 395 округлых штампованных нашивок в виде розеток, диаметром 26 - 31 мм. На обратной стороне имеется в основном 4 проволочные петли для пришивания, хотя есть и нашивки, где часть петель утрачена, а также есть один подтип розеток в количестве 91 экземпляр, у которой пять петель - 4 по сторонам и одна в центре. Несколько нашивок находилось непосредственно на черепе.

5) 16 наверший для шнуров, расположенные от левого предплечья до тазовой кости, расположены попарно в линию, с интервалом порядка 10 см, что позволяет предположить, что на момент захоронения шнуры были связаны между собой, хотя и возможно не у края самой одежды, а на некотором расстоянии, так как внутри области, ограниченной полосой бахромы и полосой завязок, а также несколько ниже нашивки-розетки отсутствуют.

6) «Бахрома», состоящая из 106 круглых в плане нашивок с двумя отверстиями в бортиках, и 107 подвесок, выполненных из двух спаянных полусфер, с одной стороны которой припаяна пирамидка из зерни, а с другой - золотая трубочка с петлей на конце.

Этот элемент одежды следует ассоциировать с шалью, или накидкой, целиком расшитой нашивками-розетками. Положение «бахромы», которая должна обрамлять лицо, вместе с положением золотых наверший шнуров-завязок относительно костяка позволяет предположить, что в ходе осуществления погребения лицо умершей, а также часть тела до середины грудины было закрыто специально натянутой шалью. 
Это предположение послужило отправной точкой для последующего анализа элементов костюма из погребения 2.

При попытках реконструкции древней одежды необходимо учитывать, что лицевые и оборотные стороны деталей одежды, ткани соотносятся с лицевыми и оборотными сторонами декорирующих элементов (Яценко, 2006. С. 368), в данном случае золотых нашивок. Это и предыдущие наблюдения позволяют сделать следующие выводы.

В процессе стягивания шали вниз и несколько влево относительно костяка низ шали сзади и слева относительно костяка соответственно сместился вверх.

При этом нашивки с левой стороны фиксируют складку ткани, к которой они крепились, в то время как край шали справа расправлен вдоль правой ноги.

Расположение нашивок имеет определенный ритмический рисунок, который в целом можно охарактеризовать как горизонтальные полосы, возможно прямые, возможно волно- или зигзагообразные. Расстояние между полосами больше, чем расстояние между нашивками внутри полосы.

На костяке ниже бахромы практически отсутствуют нашивки, обращенные лицевой стороной к зрителю, как и вообще какие либо предметы, за исключением наверший шнуров, что позволяет разграничить левый и правый борта шали.

Таким образом, исходя из полученного чертежа, представляется возможным соотнести нашивки-розетки всех типов, бахрому с мелкими нашивками и привесками, а также золотые навершия шнуров с одним предметом одежды - предположительно шалью.

Элемент одежды с бисерными рукавами. Под левой и правой руками было обнаружено два скопления разноцветного бисера и мелких бусин из различного материала. Эти скопления были расположены несколько шире костяка, заходя под кости рук лишь 
частично в районе локтей. Оба участка, каждый размером около 40-45 х 18 см, фиксируются от середины плечевой кости приблизительно до середины предплечья. Под спиной погребенной не обнаружено никаких следов бисера, что косвенно подтверждает, что описываемые объекты именно украшенные бисером обшлага рукавов одного из типов одежды, а не декоративная полоса.

Объект под левой рукой сохранился хуже, однако был зафиксирован ряд деталей, позволяющий считать предметы аналогичными - одинаковая площадь, а также отдельные сохранившиеся участки вышивки, на которых видно, что основные элементы идентичны объекту у правой руки.

Оба рукава состоят из одинакового набора бусин и бисера, а именно: бисер из синего, голубого, черного, белого стекла размером 1,5-3 мм; бисер из золота, бирюзы, коралла; мелкие округлые и бочковидные бусины из синего, желтого, белого стекла размером 4 х 6-8 мм; трубчатые пронизи из золота, коралла, сердолика, пирита длиной 5-8 мм (Аникеева, Яблонский, 2019. С. 14).

Отправной точкой для анализа этих объектов было предположение, высказанное в научном отчете Яблонским Л.Т., что трубчатые пронизи маркируют границу изобразительного поля, шириной 75 мм, внутри которой возможно существуют некие фигуры или узоры. Большое количество поврежденных участков, смещенных, перемешанных бусин, частично оставшихся, однако внутри площади участка делало эти изображения неочевидными и сложными для восприятия. В научном отчете данный орнамент описан как две линии, одна из которых заполнена спиралевидными фигурами диаметром 35 мм, а другая заполнена треугольниками размером 50 х 30 мм (Яблонскиц̆, 2014. С. 57).

Необходимо отметить, что оба этих объекта были пропитаны клеящим составом, вырезаны вместе с грунтом и в таком виде сданы в Оренбургский губернаторский историко-краевед- 
ческий музей, что позже позволило сделать ряд фотографий в условиях музейного хранения. Исключительно эти меры сделали возможным данную работу.

Автором была предпринята попытка графической реконструкции правого рукава, как наиболее сохранившегося, для чего каждой бусине был присвоен свой цветовой код, близкий к её естественному цвету. Результатом стало следующее - данный объект является сложенной пополам лентой, действительно ограниченной каймой из золотых трубочек-пронизок, с разрезом с нижней стороны (относительно костяка) - а именно декорированным широким открытым рукавом (рис. 1, 1-3).

Изображения, выявленные на рукаве оказались протомами оленей, шествующими друг за другом, таким образом, спирали превратились в загнутые спирально отростки рогов, а треугольники - в оленьи морды.

Всего на обеих половинах ленты выявлено 7 вышитых бисером фигур, площадь потревоженных участков делает возможным довести эту цифру до 10. Каждая фигура занимает участок 7 х 7 см.

Олени изображены идущими вправо, под длинной мордой с легкой горбинкой изображена согнутая передняя нога с выделенным копытом и клочком шерсти над ним. Пасть животного приоткрыта, передана валиком из бусин, клочок шерсти - борода изображен на подбородке. Массивные рога, занимающие почти треть изображения, состоят из скрученных в спирали отростков от двух до четырех штук. Подтреугольное ухо противопоставлено морде и находится между рогами и частично изображенной спиной. Глаз подтреугольной формы. Сзади изображен завиток, выполненный из того же набора бусин и бисера, что и тело животного, возможно имитирующий поднятую заднюю ногу, однако копыта при этом не изображено.

Тела оленей при этом выполнены из золотых, коралловых, каменных бусин и бисерин, в то время как промежутки между 
фигурами заполнены стеклянным или пастовым бисером, преимущественно голубого цвета, причем нашиты не бессистемно, а линиями, повторяющими контуры тела и последовательными рядами. В составе бусинного набора и фигур и фона присутствуют и все другие типы бусин и бисера, но в меньших количествах. В рукаве у левой руки посередине четко читается одна фигура оленя, рогами к костяку, направлена вправо. Однако учитывая сохранность сложно сказать, является ли этот сохранившийся участок лицевой, или внутренней стороной, в последнем случае изображения были бы направлены влево - зеркально по отношению к фигурам рукава правой руки, подобно фигурам с золотых нашивок с рукавов платья. Можно только предположить, что там изображено так же около 10 оленей, завитки рогов которых также читаются на нескольких участках левого рукава.

Изображённые на рукавах олени, хотя и выполнены в оригинальной технике, тем не менее, являются примером звериного стиля, ассоциируемого с Филипповским могильником. Подобные олени изображены на золотых обкладках деревянных чаш, на некоторых золотых нашивках из других курганов, на некоторых рукоятках роговых ложечек, а также на перстнях из самого погребения 2.

В настоящее время автор не находит возможным называть напрямую предметы одежды такими иранскими терминами, как kas (широкий плащ с длинными шнурами-завязками у шеи), sarapis (платье до щиколоток, зачастую с узкими длинными рукавами), kandis (халат, носимый внакидку, с пустыми рукавами), однако не может не констатировать сходство с ними некоторых деталей костюма из погребения 2 Филипповского кургана 1. В качестве аргумента в пользу kandis можно упомянуть тот факт, что кости рук погребенной лежали на лицевой стороне рукавов, когда кости снимали, бусины под костями остались непотревоженными. 
Женский костюм из погребения 2 не единственный в могильнике, но выделяется наличием многочисленных деталей и оригинальностью исполнения.

Так, помимо описанных выше золотых нашивок из тайника, нашивки находились в парном погребении 4 кургана 4, раскопанного в 2006 году и располагались в непосредственной близости от тела девушки 18-20 лет (рис. 1, 4). Вдоль обеих рук располагались небольшие нашивки размером в среднем 4 на 2 см в виде изогнутых кошачьих хищников, все повернуты влево (Яблонскиц̆, 2008. С. 124-129). Очевидно это платье с длинными узкими рукавами, аналогичное описанному выше. Также вокруг головы и плечевых костей были обнаружены крупные нашивки с эмалевыми вставками в виде оскаленных пантер. 7 пантер ориентированы направо, 7 налево, кроме того 2 нашивки изображают животное в фас, ими декорировались рукава «kandis». В пользу этого предположения работает то, что получившаяся кайма из нашивок изогнута и расположена относительно тела почти аналогично бисерной расшивке из 2-го погребения кургана 1 (рис. 1, 3), только несколько выше - у плечевых суставов. Если это наблюдение верно, то нашивка с изображением пантеры в фас обретает своё место, разделяя нашивки, изображающие шествие животных, на две части на месте сгиба каймы рукава по плечу. Поскольку поверх нашивок у правой руки лежат плечевые кости мужского скелета, можно предположить, что женщина была первой помещена в погребение, почти точно посередине могильной ямы, после чего рядом на край её одежд был положен мужчина.

Отсутствие в данном погребении других нашивок говорит либо об отсутствии здесь такого предмета одежды как шаль, либо о том, что она была сделана из органических материалов (и украшена, допустим, аппликациями) и истлела. Не исключена возможность и полного отсутствия такого предмета одежды в могильнике, вполне вероятно, что золотые нашивки-розетты и украшенные 
бисером рукава принадлежат одному предмету одежды - исключительно богато украшенному «kandis» или его разновидности.

Учитывая сходство в исполнении 54 нашивок в виде объемных фигур оленей из тайника 2 кургана 1 с описанными выше, можно предположить и сходство одежд, на которые они были нашиты.

В погребении 2 кургана 15 (рис. 2, 2) были расчищены нашивки в виде голов оленя, лежащие в стороне от тела, там же были обнаружены и несколько золотых наверший, аналогичных навершиям из погребения 2 кургана 1, но более простых в исполнении. Весь комплекс потревожен землеройными животными. Учитывая тот факт, что кости потревожены лишь частично, но при этом в непосредственной близости описанных нашивок и наверший не обнаружено, можно предположить, что этот предмет одежды был изначально помещён в могилу рядом с умершей, и только потом поврежден животными.

Золотые навершия также зафиксированы в кургане 7 у костяка 2, в погребении 1 кургана 16 и в кургане 12, очевидно все их следует считать навершиями шнуров-завязок и соотносить с одеждой.

В ограбленном центральном погребении 1 кургана 17 обнаружены нашивки и подвески, аналогичные находкам в кургане 15 , оттуда же происходит и массивная золотая нашивка с пастовыми вставками и привесами на золотых цепочках, аналогичная нашивке из погребения 2 кургана 1 , но более простая. Вследствие её нахождения в ограбленном комплексе, как и нахождение подобной в погребении 2 кургана 1 в стороне от костяка можно лишь предположить, что она являлась украшением некоего головного убора.

Элементов одежды, декорированных бисером, более не зафиксировано, возможно, часть из них находится в потревоженных комплексах, а часть неверно интерпретирована, исключение составляет скелет 10 из погребения 1 кургана 1 Филипповского 
II курганного могильника, где полосками бисерной вышивки украшены либо низ штанин, либо верх обуви.

Таким образом, на основе богатейшего археологического материала, полученного в ходе работы экспедиций Института ИЯЛ БНЦ УрО АН СССР и Приуральской археологической экспедиции, представляется возможным осуществить реконструкцию костюмов кочевого населения, оставившего погребальные памятники на территории Южного Приуралья (рис. 3).

\section{ЛИТЕРАТУРА}

Аникеева О.В., Яблонский Л.Т., 2019. Элементы погребального костюма жрицы из Филипповских курганов: материалы к реконструкции // Археология евразийских степей, № 1. Казань: Институт археологии имени А.Х. Халикова Академии наук Республики Татарстан. С. 12-32.

Пшеничнюк А.Х., 2018. Филипповские курганы в центре скифского мира: открытие и исследования // Коллекции Филипповских курганов из фондов Музея археологии и этнографии ИЭИ УФИЦ РАН: каталог / ИЭИ УФИЦ РАН. Уфа: Китап. С. 8-21.

Фёдоров В.К., 2012. Материалы к каталогу неизданных предметов из драгоценных металлов, найденных в кургане 1 Филипповского могильника // Филипповка. Некрополь кочевой знати IV века до н.э. на Южном Урале. Уфа: ИИЯЛ УНЦ РАН. С. 235-257.

Яценко С.А., 2006. Костюм древней Евразии: ираноязычные народы. М.: Вост. лит. 664 с.

Яблонский Л.Т., 2008. Отчёт о раскопках кургана 4 могильника Филипповка 1 на территории Илекского района Оренбургской обл. РФ в 2006 году. Том 1. Архив ИА РАН. Р-1. № 44152.

Яблонский Л.Т., 2014. Отчёт о доследовании кургана 1 могильника Филипповка 1 в 2013 году. Том I. Архив ИА РАН. Р-1. № 41778. 


\section{СВЕДЕНИЯ ОБ АВТОРЕ.}

Окороков Константин Сергеевич, Институт археологии РАН, Москва, Россия, e-mail: okorokov.arx@mail.ru
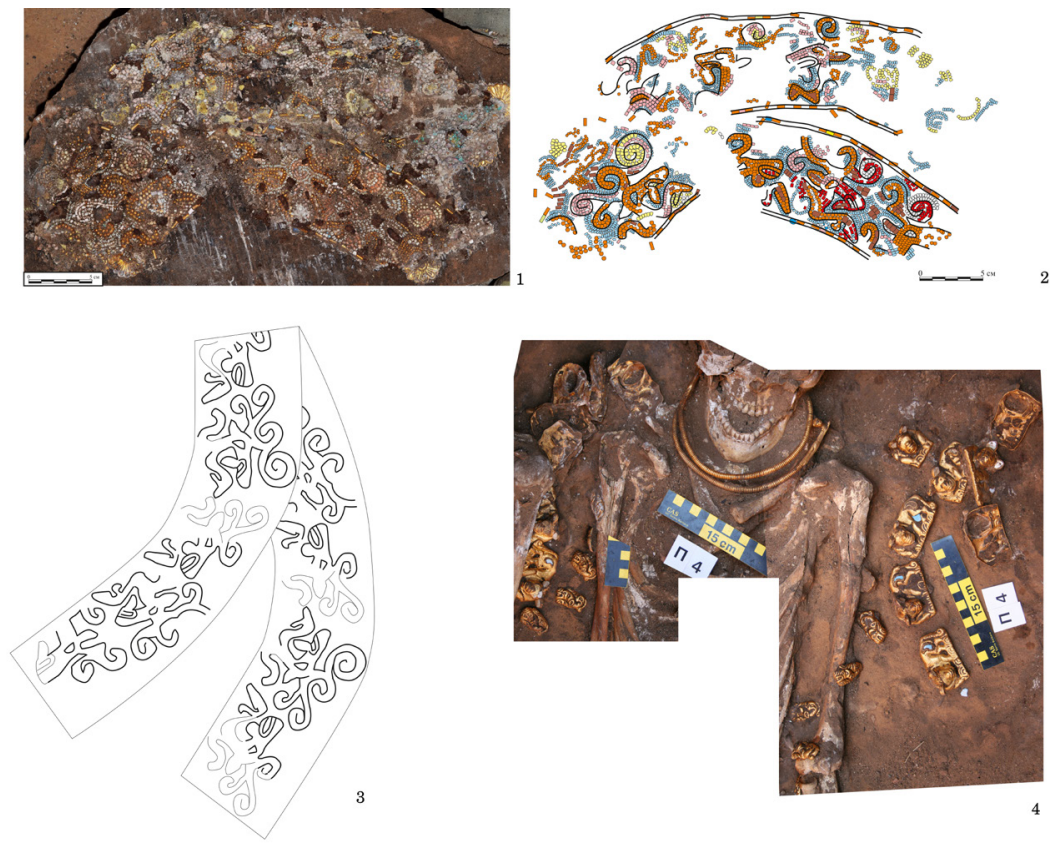

Рис.1. 1 - бисерная расшивка рукава; 2, 3 - графические реконструкции рукава с правой руки; 4 - Филипповка I курган 4 , погребение 4, деталь. 


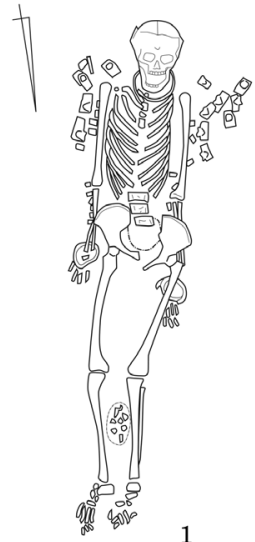

1

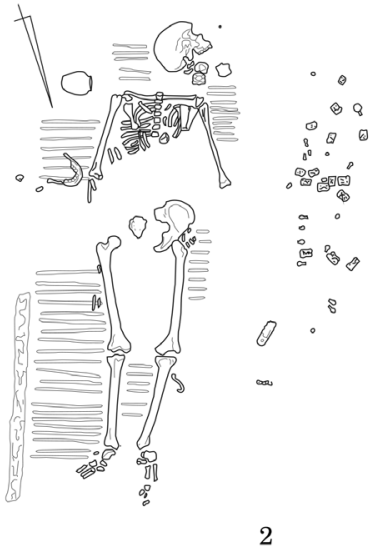

2

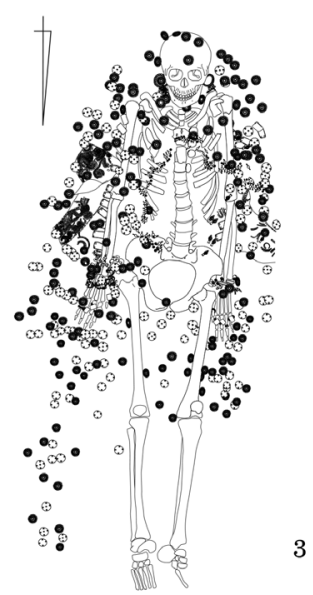

3

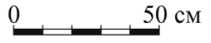

Рис.2. Погребения с золотыми нашивками. 1 - курган 4 , погребение 4; 2 - курган 15, погребение 2; 3 - курган 15, погребение 2.
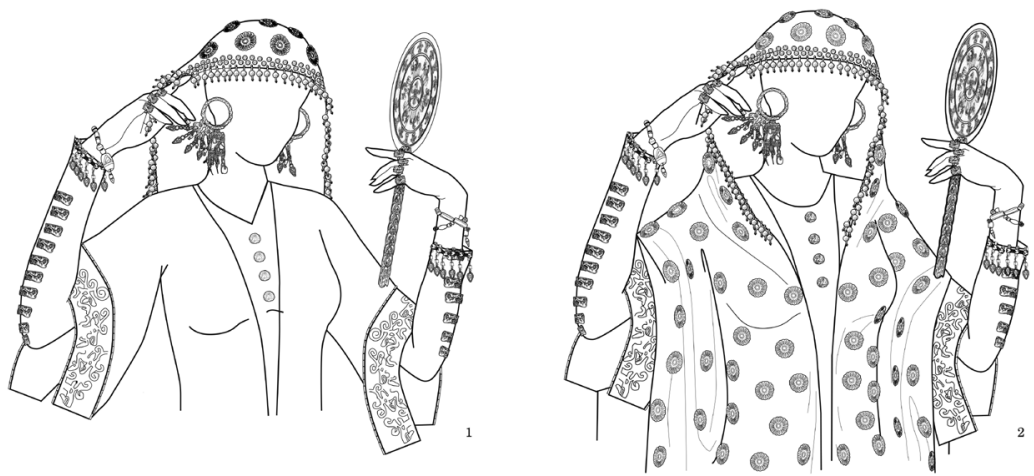

Рис.3. Графические реконструкции женского костюма из погребения 2 кургана 1. 


\section{С.В. Сиротин, Д.С. Богачук, К.С. Окороков}

\section{Филипповские параллели в погребальном обряде больших курганов некрополя «Высокая Могила - Студеникин Мар»}

Резюме. В статье рассматривается погребальный обряд больших курганов некрополя «Высокая Могила - Студеникин Мар». Исследованные курганы имеют похожий погребальный обряд и архитектурную систему. Центральные могилы и архитектура курганов имеют аналогии в курганах известного некрополя Филипповка 1. Можно утверждать, что курганы некрополя «Высокая Могила - Студеникин Мар» относятся к этой же группе памятников. Для них характерен особый погребальный обряд и инвентарь, имеющий параллели в рассматриваемых некрополях. Помимо этого, они имеют близкую хронологическую позицию. Относятся к погребальным памятникам кочевой аристократии Южного Урала.

Ключевые слова: Южный Урал, культура кочевников, погребальный обряд.

\section{S.V. Sirotin, D.S. Bogachuk, K.S. Okorokov.} Parallels from Filippovka in the funeral rite of large mounds of the «Vysokaya Mogila - Studenikin Mar» necropolis.

Abstract: The article discusses the funeral rite of large mounds of the necropolis «Vysokaya Mogila - Studenikin Mar». The investigated burial mounds have a similar burial rite and architectural system. The central graves and the architecture of the mounds have analogies in the mounds of the famous Filippovka 1 necropolis. It can 
be argued that the mounds of the «Vysokaya Mogila - Studenikin Mar» necropolis belong to the same group of monuments. They are characterized by a special burial rite and grave goods, which have parallels in the considered necropolises. In addition, they have a close chronological position. Mounds belong to the burial monuments of the nomadic aristocracy of the Southern Urals.

Key words: South Ural, nomad culture, funeral rite.

Курганный некрополь «Высокая Могила - Студеникин Мар» расположен на территории Оренбургской области в 16 км к югу от с. Дедуровка. Данный памятник представляет собой крупный могильник, в составе которого выделяется несколько курганных групп, насчитывающих более 50 курганов разной величины, включая большие сооружения раннекочевнической знати. В природно-географическом отношении район исследований занимает центральное местоположение в Оренбургской области и располагается на стыке трех природных округов, входящих в состав Общесыртовско-Предуральской возвышенной степной провинции (рис. 1). Курганная группа находится к югу от р. Урал на территории Урало-Илекского ландшафтного округа с условиями типичной степи на южных черноземах (Чибилев, 1996. С. 155-156).

В 2016-2019 гг. Приуральской экспедицией ИА РАН были исследованы три кургана, относящихся к категории больших (курганы №№ 2, 5 группы «Богатырские Могилки» (центрально-восточная часть некрополя) и курган 1 группы «Студеникин Мар» (западная часть некрополя). Помимо этого было исследовано еще четыре кургана, относящихся к позднесарматской культуре. В рамках данной работы будут рассмотрены большие курганы, которые в культурно-хронологическом плане относятся к раннепрохоровскому времени. 
При рассмотрении конструктивных особенностей насыпей исследованных больших курганов, обращает на себя внимание схожесть погребального обряда, архитектура насыпей и планиграфическая организация курганных сооружений. Погребальный обряд и вещевые комплексы некрополя «Высокая Могила - Студеникин Мар» имеют аналогии с материалами некрополя Филипповка 1.

В основании всех трех исследованных курганов в центре подкурганной площадки выявлены погребения с дромосами, в которых исследованы коллективные захоронения.

В кургане 2 группы «Богатырские Могилки» центральное погребение (погребение 1) представляло собой яму подпрямоугольной в плане форму с примыкающим к ней с юго-востока коротким дромосом. Длинной осью дромос был ориентирован по линии юго-восток - северо-запад. Около начала дромоса в материке фиксировались столбовые ямки. Ко времени исследования могильная яма центрального погребения была значительно разрушена вследствие многочисленных ограблений. Особенно сильные разрушения от экскаватора фиксировались в западной части ямы (рис. 1, 2, 2,1).

В дромосе был найден разбитый и смятый в древности бронзовый котел. В заполнении могильной ямы на разной глубине были найдены бронзовые наконечники стрел, бронзовые и железные ворворки, бронзовые бляхи, железный вток копья, железный колчанный крючок и ряд других категорий инвентаря.

На стенке могильной ямы in situ были обнаружены два уздечных набора, включающих железные удила, железные стержневидные двудырчатые псалии, биметаллические псалии С-видной схемы, пластинчатые орнаментированные налобники, железные дуговидные нахрапники, украшения узды (рис. 1, 4).

В кургане 5 группы «Богатырские Могилки» могильная яма центрального погребения (погребение 2) имела подквадратную в плане форму с закругленными с севера углами (рис. 1, 3, 3,1). С 
юго-востока к яме примыкал дромос. Дромос был ориентирован по линии юго-юго-восток - северо-северо-запад. В 1 м от устья дромоса по краям фиксировались две столбовые ямы от опорной конструкции. В устье дромоса были обнаружены три бронзовых котла. В одном из котлов был уложен бронзовый ковш.

В основе погребальной конструкции кургана 1 группы «Студеникин Мар» также находилось центральное погребение с дромосом (погребение 4). Яма округло-овальной формы, к которой с юга примыкал дромос (рис. 2, 1, 1,1). В погребении обнаружено коллективное захоронение. В западной части ямы были расчищены остатки деревянного ящика, в котором находился мужской костяк, ориентированный в южный сектор (рис. 2, 1, 2). Были зафиксированы остатки деревянного перекрытия ящика и фрагменты стенок. Дно погребального ящика представляло собой погребальное ложе из хорошо обработанных и плотно подогнанных поперечных плах. В северной части ямы были расчищены еще три костяка, уложенных на погребальные ложа (носилки?) из продольных деревянных плах, скрепленных поперечинами (рис. 2, 1, 3). Из инвентаря в центральном погребении были найдены железный колчанный крюк, бронзовые наконечники стрел и ряд других вещей.

Дромосные погребальные сооружения широко известны в степных комплексах Евразии VI-IV вв. до н. э. Вопросы, связанные с появлением погребений дромосного типа в южноуральских степях до сих пор остаются открытыми (Смирнов, 1978; Исмагилов, 1996; Яблонский, 2011а). Их появление фиксируется еще в конце VI-V вв. до н. э., однако их наибольшее распространение относится к концу V-IV вв. до н. э. (Мошкова, Малашев, Мещеряков, 2011).

На Южном Урале дромосные сооружения представлены в могильниках единичными случаями (Переволочан I, Teмир, Большой Климовский курган и др.) и лишь в Филипповке 
данный тип погребений выявлен в подавляющем большинстве курганов. Из 30 курганов только лишь в семи сооружениях наблюдается иной тип центральных погребений. Не исключена подобная ситуация в курганах некрополя «Высокая Могила - Студеникин Мар». Разумеется, на основании раскопок трех больших курганов преждевременно делать абсолютные выводы применительно ко всем его курганным сооружением, однако само по себе нахождение дромосных могил во всех исследованных к настоящему времени курганах, факт весьма примечательный. Вполне вероятно, что данный тип погребального сооружения в данном некрополе, также как в Филипповке окажется преобладающим.

Известно, что погребальные камеры с дромосами в курганах Филипповского могильника имели прямоугольную, округлую/овальную или крестообразную форму (Пшеничнюк, 2012; Яблонский, 2013). Сложно объяснить с достаточной долей достоверности такое разнообразие форм погребальных камер в дромосных могилах. Вряд ли это было связано с фактором социальных различий. Вероятнее всего, наличие округлых, прямоугольных и крестообразных камер могло быть связано с определенными этнографическими различиями отдельных групп родовой знати, входящих в ядро военно-племенного объединения номадов Урало-Илекского междуречья и удостоившихся быть погребенными на элитарном некрополе.

Центральное погребение кургана 1 группы «Студеникин Мар», имеющее округлуюlовальную форму имеет аналогии в самой немногочисленной группе курганов Филипповки (курганы $1,10,13,14,26)$. Центральные погребения курганов 2 и 5 группы «Богатырские Могилки», имеющие подпрямоугольную\подквадратную форму, напротив сопоставимы с самой представительной группой курганов Филипповского некрополя (курганы 11, $12,17,23,25,27,28,29,30)$. 
Характерной конструктивной чертой курганов, имеющих дромосные погребения в Филипповском могильнике, является наличие круговых валиков из материкового суглинка, полученного при сооружении ямы. Такие валики могли быть сплошным или иметь один или несколько разрывов, в том числе, с юга или юго-востока. Валики фиксируются в 20 из 21 кургана с дромосными погребениями. Во всех трех исследованных курганах некрополя «Высокая Могила - Студеникин Мар» зафиксированы валики, выполненные в такой же конструктивной манере.

В центральной части всех трех исследованных курганов были выявлены участки сильно прокаленной почвы и остатки сгоревшей деревянной конструкции. Во всех курганах деревянные конструкции выгорели практически полностью, в связи с чем, проследить их архитектурный характер не представлялось возможным. Можно лишь предполагать, что исходя из общей архитектуры кургана, конструкция могла быть устроена в виде радиально уложенных бревен, так называемого «шатрового» типа. Следы мощного кострища фиксировались в стратирафических разрезах контрольных бровок, на погребенной почве и на материковой поверхности.

В Филипповке остатки деревянных надмогильных конструкций выявлены в 16 курганах, имеющих в своей основе дромосные могилы (Пшеничнюк, 2012; Яблонский, 2013).

Деревянные надмогильные сооружения представляли собой перекрытие из радиально уложенных бревен. Деревом накрывался и дромос, о чем свидетельствуют столбовые ямки по краям хода. Надмогильное перекрытие в виде радиально уложенных бревен получило в литературе название «шатрового». В этой связи, следует отметить, что в настоящее время среди исследователей нет единой точки зрения о характере данной конструкции. А.Х. Пшеничнюк считал, что бревна, опираясь на валик, устанавливались под острым углом, создавая полую конструкцию, над кото- 
рой затем возводилась насыпь из земли, либо дерновых блоков. Затем, в данное сооружение через дромос, по мере необходимости, совершались дополнительные подзахоронения (Пшеничнюк, 2012, С. 62-63). На наш взгляд более предпочтительной является точка зрения, согласно которой считается, что радиально уложенные бревна являются лишь имитацией или моделью шатра над центральным погребением и возведение насыпи или «закрытие» кургана осуществлялось после того, как могильная яма была заполнена (Яблонскиц̆, 2013, С. 43; Сиротин и др., 2019). Вероятнее всего, бревна перекрытия укладывались в радиальном направлении над центральным погребением, образуя невысокую конструкцию, а не выстраивались в виде островерхого полого шатра. Этим, вероятно, объясняется современный внешний вид насыпей больших курганов в Южном Приуралье. Все они, в отличие от скифских курганов, более островерхих, собранных и компактных, имеют растянутые параметры насыпи и сильно уплощенную вершину.

В Филипповке бревна перекрытия в ряде курганов имеют следы обугливания, когда горение осуществляется без доступа воздуха. Следы горения или обугливания конструкции были зафиксированы в 11 курганах из 19, имеющих деревянные надмогильные конструкции (Пшеничнюк, 2012; Яблонскиц̆, 2011; 2013). Применительно к курганам из некрополя «Высокая Могила - Студеникин Мар» следует обратить внимание на то, что деревянные конструкции выгорели полностью, оставив мощные прокалы в центральной части курганных сооружений. На Южном Урале подобная ситуация зафиксирована лишь в двух курганах (курган 2 и 5) могильника «Ивановские I курганы» (Пшеничнюк, 1983; Сиротин, 2018).

К настоящему времени однозначного ответа на вопросы, связанные с горением надмогильных сооружений в курганах ранних кочевников Южного Урала нет. Одни исследователи связывают поджог деревянной конструкции с действиями грабите- 
лей (Пженичнюк, 2012; Таиров, 2014), другие считают их принадлежностью погребального ритуала.

Следует отметить, что обе эти версии не вполне объясняют своеобразную избирательность в совершении огненного ритуала или же поджога в результате грабежа, поскольку не все деревянные конструкции в курганах имели признаки горения. Возможно, огненный ритуал при совершении обрядовых действий полагался определенной группе, но увязать это достоверно с социальным или культовым статусом умерших сложно. На наш взгляд, в данной ситуации, можно предполагать наличие определенного этнографического элемента, связанного с применением огненных практик в системе погребальной обрядности Филипповского некрополя, могильников Переволочан I, «Ивановские I курганы» и ряда других. Если допустить версию грабительского происхождения горения, то такая избирательность грабителей в поджогах надмогильных сооружений при ограблении курганов не вполне понятна.

Трудно объяснить и разницу в характере горения надмогильных сооружений. Отчетливо фиксируется группа курганов с обугленными конструкциями, когда горение осуществляется без доступа воздуха (Филипповка, Переволочан I) и группа курганов, где конструкция выгорела полностью, не испытывая недостатка кислорода (могильники «Высокая Могила - Студеникин Мар», «Ивановские I курганы»). Вероятно, такая ситуация может быть связана с конструктивными особенностями надмогильного сооружения и курганной насыпи. В этом случае в условиях горения надмогильного перекрытия кислорода было достаточно, в отличие от курганов с обугленными конструкциями.

При анализе конструктивных особенностей курганов некрополя «Высокая Могила - Студеникин Мар» следует обратить внимание на выявленные в курганах 2 и 5 группы «Богатырские Могилки» подземные ходы. В кургане 2 был исследован 
подземный ход, длиной более 15 м, устье которого заходило в центральное погребение (рис. 2, 4). Подземный ход располагался в восточной поле. Начало хода находилось за пределами вала вокруг центрального погребения и, вероятнее всего, у границы первоначальной насыпи. Длинной осью ход был ориентирован по линии восток-северо-восток - запад-юго-запад. Глубина хода от материковой поверхности составила до 1,7 м.

Около входа в подземный ход был найден массивный бронзовый ковш, в который были уложены два уздечных набора, включавших в себя железные удила, стержневидные двудырчатые псалии, бронзовый орнаментированный пластинчатый налобник, бронзовые пронизи, бронзовые уздечные бляхи (рис. 2, 5).

На подкурганной площадке кургана 5 было расчищено два подземных хода. Подземные ходы были устроены в северной части, ориентированы по линии северо-северо-запад - юго-юго-восток и соединялись в 2-5 м от ямы центрального погребения. Длина хода I составила около 11,5 м, длина хода II до его соединения с ходом I составила около 7,5 м, глубина от уровня материковой поверхности 1,33 м (ход I) - 1,76 м (ход II). Подземные ходы пробивали северную стенку ямы ближе к ее восточному углу. В заполнении входной ямы хода I были найдены бронзовые трехлопастные наконечники стрел и железные панцирные чешуйки.

Подземные ходы, ведущие от полы насыпи к центру, выявлены в пяти курганах Филипповского могильника. А.X. Пшеничнюком такие ходы интерпретировались как грабительские лазы (Пиеничнюк, 2012. С. 66). Однако находки, сделанные в этих ходах, в том числе ритуальные человеческие жертвоприношения, кости лошади в анатомическом сочленении, позволяют предполагать их ритуальный характер и рассматривать как часть погребально-ритуальной архитектуры (Яблонский, 2013. С. 43-45; Яблонский, 2017. С. 189). Приме- 
чательным является факт нахождения богатого жертвенного комплекса около входной ямы подземного хода в кургане 2 группы «Богатырские Могилки» (Сиротин и др., 2018). Подобные ходы известны в кургане 11 могильника Переволочан I (Сиротин, 2010; 2016) в юго-восточной Башкирии, в курганах Бесшатырского могильника в Семиречье и некоторых скифских курганных сооружениях Северного Причерноморья.

При исследовании насыпей курганов, в южной поле были найдены скопления костей лошади. Подобная картина расположения костей лошади, символизирующая присутствие коня в погребальном ритуале фиксируется также в 20 курганах Филипповки.

В кургане 5 группы «Богатырские Могилки» и кургане 1 группы «Студеникин Мар» вокруг центрального погребения располагались впускные захоронения. Практически все выявленные впускные погребения в исследованных курганах располагались за пределами глиняного валика, и лишь одно захоронение (погребение 5 кургана 1 группы «Студеникин Мар») погребение было устроено в пределах первоначальной конструкции вблизи центральной могилы. Конструктивно выявленные впускные захоронения в курганах 5 группы «Богатырские Могилки» и кургане 1 группы «Студеникин Мар» относятся к подбойным погребениям (4 погребения), одно погребение в простой яме, одно погребение катакомбного типа (І тип по К.Ф. Смирнову) и одно совершено на древнем горизонте. Все они, за исключением погребения классического прохоровского времени II в. до н.э. (погребение 1, курган 5 группы «Богатырские Могилки»), относятся к одному культурно-хронологическому горизонту вместе с центральными погребениями.

Анализ вещевых комплексов также обнаруживает близкие параллели с определенным кругом вещей из Филипповки. Прежде всего, это элементы конского снаряжения, бронзовые котлы и ряд других категорий. Хронологически исследованные курга- 
ны некрополя «Высокая Могила - Студеникин Мар» относятся к последней трети - концу IV - рубежу IV-III вв. до н.э.

В этой связи, обращает на себя внимание, что на Южном Урале выделяется целая серия курганных могильников и больших одиночных курганов сходных по обрядовым характеристикам, планиграфии и архитектуре, по инвентарю, расположенных в Урало-Илекском (Филипповка 1, Филипповка 2, «Высокая Могила - Студеникин Мар») и Урало-Сакмарском междуречье (Переволочан I, Яковлевка II, Ивановские I курганы), а также в верховьях р. Урал (Темир).

\section{ЛИТЕРАТУРА}

Исмагилов Р.Б., 1996. Сарматское окно в Европу // Актуальные проблемы древней истории и археологии Южного Урала / ред. Н. А. Мажитов, М. Ф. Обыденнов. Уфа: Изд-во «Восточный университет». С. 32-71.

Мошкова М.Г., Малашев В.Ю., Мешеряков Д.В., 2011. Дромосные и катакомбные погребения Южного Приуралья в савроматское и раннесарматское время // Погребальный обряд ранних кочевников Евразии. Материалы и исследования по археологии юга России / Ред. Л.Т. Яблонский, С.И. Лукьяшко. Ростов-на-Дону: Изд-во ЮНЦ РАН. Вып. III. С. 162-167.

Пшеничнюк A.X., 1983. Культура ранних кочевников Южного Урала. М.: Наука. 199 с.

Пшеничнюк A.X., 1995. Переволочанский могильник // Курганы кочевников Южного Урала / Ред. Агеев Б.Б. Уфа: Гилем. C. 62-96.

Пиеничнюк A.X., 2012. Филипповка. Некрополь кочевой знати IV века до н.э. на Южном Урале / Отв. ред. Н.С. Савельев. Уфа: ИИЯЛ УНЦ РАН. 280 с. 
Сиротин С.B., 2010. Курган № 11 курганного могильника Переволочан в Зауральской Башкирии // Археология и палеоантропология евразийских степей и сопредельных территорий (МИАР, № 13) / ред. Герасимова М. М., Малашев В. Ю., Мошкова М. Г. М.: Таус. С. 323-337.

Сиротин С.В., 2016. Об относительной хронологии и датировке Переволочан I // Константин Фёдорович Смирнов и современные проблемы сарматской археологии. Проблемы сарматской археологии и истории / Ред. Л.Т. Яблонский, Л.А. Краева. Оренбург: ОГПУ. С. 253-264.

Сиротин С.В., 2018. Хронология и планиграфия курганного некрополя Ивановские I курганы в Зауральской Башкирии // Этнические взаимодействия на Южном Урале. Сарматы и их окружение: материалы VII Всерос. (с международном участием) науч. конф. / отв. ред. А.Д. Таиров. Челябинск: Государственный исторический музей Южного Урала. С. 132-139.

Сиротин С.В., Богачук Д.С., Окороков К.С., 2018. Курганная группа «Богатырские могилки» № 4 (Оренбургская область, Оренбургский район) // Города, селища, могильники. Раскопки 2017. Материалы спасательных археологических исследований / А.В. Энговатова (отв. ред.). М.: Институт археологии РАН. Т. 25. С. 334-339.

Сиротин С.В., Маслов В.Е., Богачук Д.С., 2019. Аристократия кочевников Южного Урала. Филипповские курганы // Природа. № 1. С. 50-56.

Смирнов К.Ф., 1978. Дромосные могилы ранних кочевников Южного Приуралья и вопрос происхождения сарматских катакомб // Вопросы древней и средневековой археологии Восточной Европы / ред. В.И. Козенкова, Ю.А. Краснов, И.Г. Розенфельдт. М: Наука. С. 56-64.

Таиров А. Д., 2014. Сожжение как результат ограбления (по 
материалам Южного Зауралья) // Труды IV (XX) Всероссийского археологического съезда в Казани. Т. 2 / Отв. ред. А. Г. Ситдиков, Н. А. Макаров, А. П. Деревянко. Казань: Отечество. С. 241-243.

Яблонский Л.Т., 2011. Новые раскопки могильника Филипповка 1 // Естественно-научные методы в изучении Филипповского 1 могильника / Отв. ред. Л. Т. Яблонский. Москва: ТАУС. С. 7-19.

Яблонский Л.Т., 2011а. Погребальный обряд ранних кочевников Приуралья переходного времени и вопросы археологической периодизации памятников // Погребальный обряд ранних кочевников Евразии. Материалы и исследования по археологии юга России / Ред. Л.Т. Яблонский, С.И. Лукьяшко. Ростов-на-Дону: Изд-во ЮНЦ РАН. Вып. ІІІ. С. 235-240.

Яблонский Л.Т., 2013. Золото сарматских вождей. Элитный некрополь Филипповка 1 (по материалам раскопок 20042009 гг.). Каталог коллекции. Книга 1. М: ИА РАН. 232 с.

Яблонский Л.Т., 2017. На востоке скифской ойкумены. М.: Грифон. 400 с.

\section{СВЕДЕНИЯ ОБ АВТОРАХ:}

Сиротин Сергей Викторович, к.и.н., Институт археологии РАН, Москва, Россия, e-mail: sirotinsv70@mail.ru

Богачук Дарья Сергеевна, Институт археологии РАН, Москва, Россия, e-mail: BogachukDS@iaran.ru

Окороков Константин Сергеевич, Институт археологии РАН, Москва, Россия, e-mail: okorokov.arx@mail.ru 

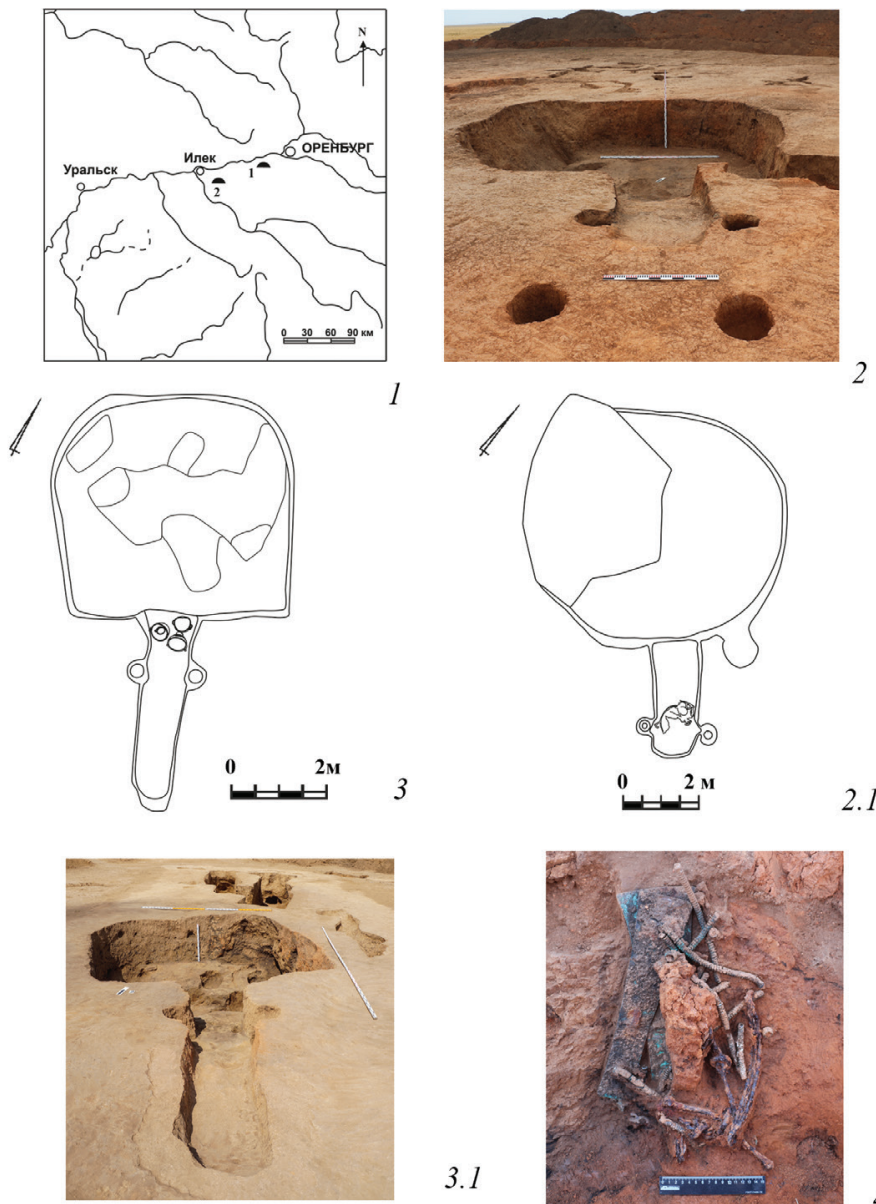

3.1

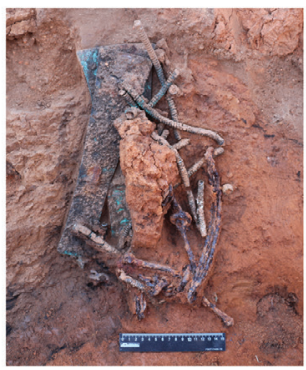

Рис. 1. Курганный могильник «Высокая Могила - Студеникин Мар». Группа «Богатырские Могилки». 1 - расположение некрополя в Оренбургской области; 2 - 2.1 - центральное погребение кургана 2 группы «Богатырские Могилки»; 3 - 3.1 - центральное погребение кургана 5 группы «Богатырские Могилки»; 4 - уздечные наборы в центральном погребении кургана 2 группы «Богатырские Могилки». 

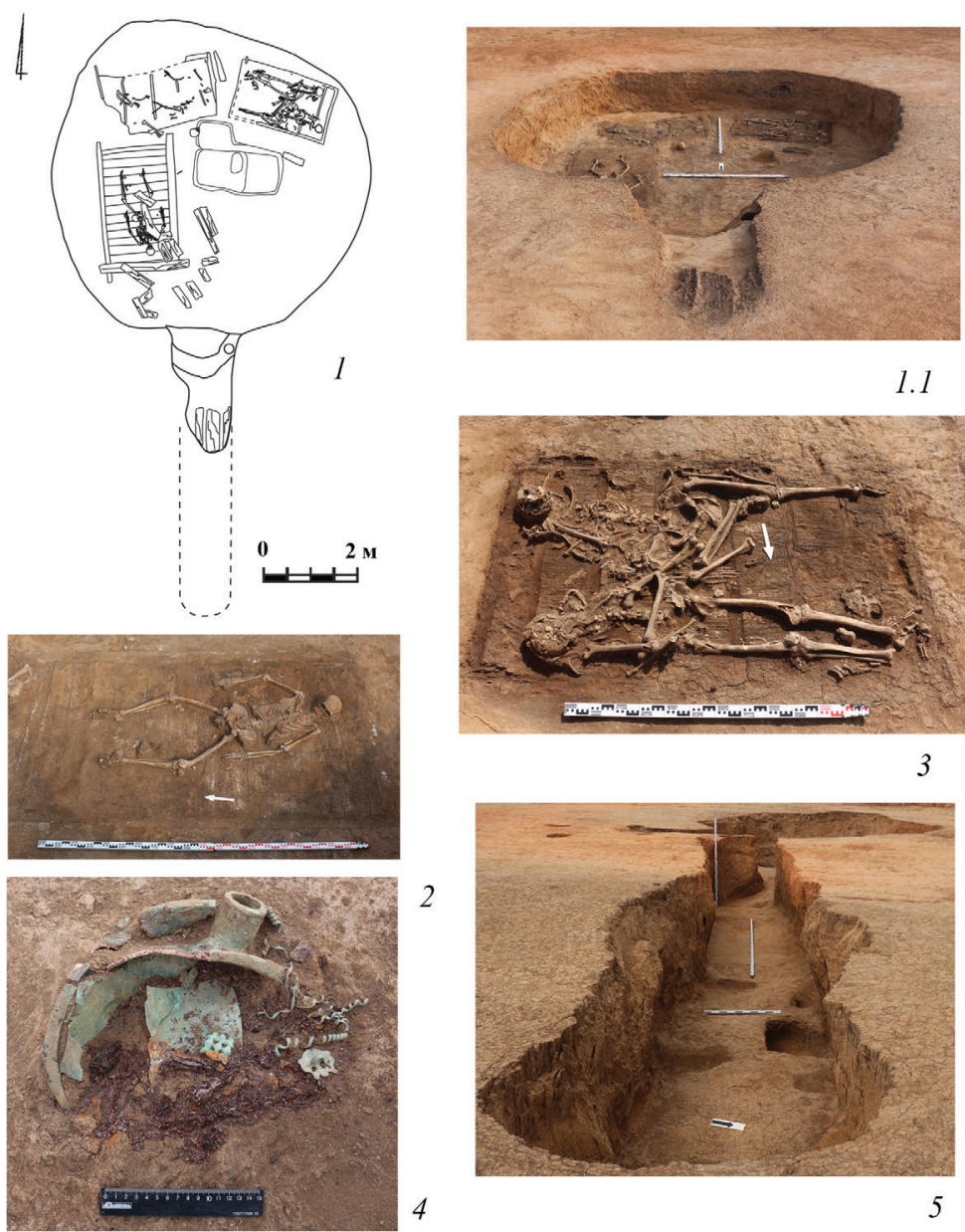

Рис. 2. Курганный могильник «Высокая Могила - Студеникин Мар». Группа «Студеникин Мар» и «Богатырские Могилки». 1 - 3 - центральное погребение кургана 1 группы «Студеникин Мар»; 4 - жертвенный комплекс около входной ямы подземного хода кургана 2 группы «Богатырские Могилки»; 5 - подземный ход в кургане 2 группы «Богатырские Могилки». 


\section{С.В. Сиротин, Д.С. Богачук, К.С. Окороков}

\section{Позднесарматские комплексы курганной группы «Высокая Могила» на Южном Урале.}

Резюме: В статье представлены предварительные результаты работ Приуральской археологической экспедиции Института археологии РАН в Оренбургской области в 2018 г. В курганах № 7, 25 группы «Высокая Могила» выявлено по два погребения. В погребениях найдены фрагменты керамических сосудов, фрагменты бронзового зеркала, длинный железный нож и другие категории инвентаря. Черепа погребенных имеют следы искусственной деформации. Погребальный обряд и инвентарь имеют аналогии в комплексах позднесарматской культуры Азиатской Сарматии II-III вв. н.э. Исследованные курганы определяют верхнюю хронологическую границу некрополя.

Ключевые слова: курганы, погребальный обряд, Южный Урал, ранние кочевники, позднесарматская культура.

\section{S.V. Sirotin, D.S. Bogachuk, K.S. Okorokov}

\section{Late Sarmatian complexes of the «Vysokaya Mogila» kurgan group in the South Urals.}

Abstract: The article presents the preliminary results of the work of the Ural archaeological expedition of the Institute of Archeology RAS the Orenburg region in 2018. In kurgans No. 7, 25 of the «Vysokaya Mogila» group, two burials were found. Fragments of ceramic vessels, fragments of a bronze mirror, a long iron knife and other categories of inventory were found in the burials. The skulls of people buried in graves have traces of artificial deformation. The 
burial rite and implements have analogies in the complexes of the Late Sarmatian culture of Asiatic Sarmatia in the 2nd - 3rd centuries AD. The investigated burial mounds define the upper chronological border of the necropolis.

Key words: burial mounds, burial rite, South Urals, early nomads, late Sarmatian culture.

В 2018 г. Приуральской экспедицией Института археологии РАН в Оренбургской области проводились спасательные археологические исследования на курганной группе «Высокая Могила» № 1, входящей в состав некрополя «Курганное поле «Высокая Могила - Студеникин Мар».

Исследования 2018 г. на курганном некрополе являлись продолжением работ, начатых в 2016-2017 гг., в ходе которых в больших курганах, имевших в своем основании дромосные погребения и сгоревшие деревянные конструкции, были выявлены комплексы последней трети IV в. до н.э. и комплекс III-II вв. до н.э., а в малых курганах были исследованы комплексы позднесарматской культуры II-III вв. н.э. (Сиротин и др., 2018; Сиротин, Богачук, 2018).

Курганная группа «Высокая Могила» № 1 занимает центральное положение в некрополе «Курганное поле «Высокая Могила - Студеникин Мар». Основной задачей экспедиции в 2018 г. являлось изучение малых курганов, входивших в состав группы «Высокая Могила» и располагавшихся в непосредственной близости от самого крупного кургана в некрополе, «царского» - кургана № 1 (диаметр 140 м, высота 7 м). Исследования проводились с целью выяснения их культурно-хронологической принадлежности в контексте дальнейшего исследования планиграфической организации и хронологии некрополя. 
В двух курганах, исследованных в 2018 г. были найдены комплексы позднесарматской культуры (курганы №№ 7, 25).

В насыпи кургана № 7 (диаметр 16 м, высота 0,12 м) были найдены остатки тризн в виде отдельных костей животных (лошади). Помимо этого, в насыпи кургана были найдены фрагменты от четырех лепных сосудов. Необходимо отметить, что находки костей животных и керамики в насыпях курганов позднесарматского времени - достаточно распространенное явление на территории Азиатской Сарматии (Мошкова, 2009. С. 91).

В юго-западном секторе, в 7,5 м юго-западнее условного центра кургана, практически у современной границы насыпи, на уровне древней поверхности, было выявлено скопление лепной керамики (сосуд № 1) (рис. 1, 1). В западной поле кургана были найдены фрагменты лепного тонкостенного сосуда № 2. В юго-западном секторе кургана был найден фрагмент красноглиняного гончарного сосуда (сосуд № 3).

В восточной поле кургана были найдены фрагменты лепного сосуда № 4 (рис. 1, 2). Судя по найденным фрагментам, этот сосуд представлял собой небольшую курильницу прямоугольной формы, встречающихся в комплексах позднесарматской культуры Азиатской Сарматии II-III вв. до н.э. (Скрипкин, 1984. С. 57; Мошкова, 1989. Табл. 80; Малашев, Яблонский, 2008. С. 66).

Помимо этого, в центральной части кургана, юго-восточнее условного центра были найдены четыре бронзовые накладки, а также два бронзовых предмета округлой и овальной формы. Вероятнее всего, эти предметы были вынесены степными грызунами из погребения № 2 .

На подкурганной площадке выявлено два погребения. Одно погребение (погребение № 1) (рис. 1, 3, 3.1). было найдено в северо-западном секторе кургана. Захоронение совершено в яме подбойной конструкции, ориентированной длинной 
осью в меридиональном направлении. Входная яма и подбойная ниша узкие, вытянутых пропорций, что традиционно отличает познесарматские подбои от подбойных могил савроматского и раннесарматского времени. Входная яма неправильной подпрямоугольной формы имела размеры по линии дна 1,8х0,35 м, ориентирована по линии север-юг, углублена в материк до 0,18-0,24 м. Дно входной ямы представляло собой предвходовую ступень, и было выше дна погребальной камеры на 0,37-0,4 м. Подбой был устроен в длинной восточной стенке. Погребальная камера неправильной вытянутой подтрапециевидной формы размерами по линии дна 1,95х0,6-0,65 м, ориентирована по линии север-юг, углублена в материк до 0,65-0,68 м. Подбойные погребения узких пропорций достаточно широко представлены в погребальных памятниках позднесарматской культуры южноуральского региона в таких памятниках как Лебедевка, Покровка 10 и др. (Мошкова, 2009. С. 133; Малашев, Яблонский, 2008. С. 44).

В погребении был найден мужской костяк, ориентированный головой на север. Череп погребенного имел следы искусственной деформации. Северная ориентировка и искусственная деформация черепа, в целом, характерны для широкого круга комплексов позднесарматского времени, но, вместе с тем, их особо высокая концентрация отмечается для южноуральских памятников (Мошкова, 2009. С. 133).

Из погребального инвентаря примечательной находкой является, найденный около правого крыла таза железный нож с прямой спинкой (рис. 1, 4), на рукояти которого фиксировались остатки деревянных накладок и бронзовая двусоставная обойма, крепившаяся к полотну рукояти железными штифтами-заклепками. На окончание рукояти ножа был надет бронзовый фигурный наконечник-навершие, состоящий из двух половин с плоской дисковидной шляпкой. Общая 
длина ножа 23,5 см, ширина лезвия до 1,3 см, длина рукояти до 10,5 см, ширина рукояти до 1,5 см.

Такие ножи имеют аналогии в позднесарматских памятниках Южного Приуралья (Мошкова, 1989. С. 199) и, в целом, широко представлены в комплексах на обширной территории от Нижнего Поволжья до Средней Азии (См. обзор: Малашев, Яблонский, 2008. С. 65). На Южном Урале подобные ножи были найдены в могильниках Комсомольский VI (Пшеничнюк, 1983. Табл. LVI, 9), Темясово (Пшеничнюк, Резяпов, 1976. Рис. 1, 7), Агаповка, Георгиевский Бугор, Восточно-Курайлинский, Целинный I (Боталов, Гуцалов, 2000. Рис. 17, 9; 23, 3; 26, 10; 28, 3; $33,18)$. Наиболее близкие аналогии происходят из курганов 41 и 43 могильника Покровка 10 в Оренбургской области (Малашев, Яблонский, 2008. Рис. 162, 9; Рис. 204, 1). Дата комплексов с такими ножами определяется в пределах второй половины II - III в. до н.э. (Малашев, Яблонский, 2008. С. 65).

Погребение № 2 (рис. 1, 5, 5.1). было найдено в юго-восточном секторе кургана и было совершено в простой яме узкой подпрямоугольной формы размерами 2,2х0,55 м. Такие ямы, наряду с подбойными погребениями также составляют значительную количественную группу погребальных сооружений в позднесарматских памятниках Южного Приуралья (Мошкова, 2009. С. 133). Длинной осью яма ориентирована по линии запад-северо-запад - восток-юго-восток, углублена в материк до 1,41-1,45 м. При исследовании ямы был обнаружен тлен от древесной коры (береста?), в которую был завернут костяк, найденный на дне ямы. Был расчищен костяк взрослого человека (мужской?) в вытянутом положении, ориентированный головой на запад-северо-запад. В области грудной клетки отсутствовала большая часть позвоночника и ребра. Разрушения скелета произведены, вероятнее всего, степными грызунами, норы которых 
фиксировались в заполнении и стенках ямы. Череп погребенного имел следы искусственной деформации.

Около левой голени был найден бронзовый литой сосудик-черпачок с характерной втулкой для рукояти (рис. 1, 6), аналогии которому в комплексах Южного Урала неизвестны. Здесь же был найден длинный (длина 29,7 см) четырехгранный каменный оселок (рис. 1, 7). Кроме того, в погребении, около правой голени найдена бронзовая пронизь.

Помимо двух погребений на подкурганной площадке, в южной поле были найдены две пустые ямы подпрямоугольной формы (яма 1 и 2).

Курган № 25 (диаметр 32 м, высота 0,24 м) располагался с северо-западной стороны от кургана № 1. При исследовании насыпи были найдены многочисленные фрагменты (более 160 фр.) лепных керамических сосудов (сосуды №№ 1-8, 10) и гончарного сосуда (сосуд № 9). Большая часть находок концентрировалась в северных секторах. В восточной поле кургана найдена костяная проколка. Помимо этого, в насыпи встречались кости лошади, как в разрозненном виде, так и в виде скоплений. Под насыпью, в юго-восточном секторе, было выявлено два погребения совершенных в простых ямах вытянутых пропорций.

Погребение № 1 было найдено к востоку от центра кургана. Захоронение было совершено в простой подпрямоугольной яме размерами 2,34х0,65-0,75 м. Длинной осью яма ориентирована по линии северо-северо-восток - запад-юго-запад. Яма углублена в материк до 0,5-0,52 м. В северной части ямы, на дне были обнаружены кости взрослого человека. Кости были сложены компактно, вне анатомического порядка. Среди костей был найден череп, который имел следы искусственной деформации. Из погребального инвентаря в заполнении ямы были найдены железные изделия в виде коротких столбиков со шляпками (заклепки?). 
Погребение № 2 было выявлено к юго-востоку от центра и совершено в яме подпрямоугольной формы размерами 2,7х0,8 м. Длинной осью яма ориентирована по линии запад-восток. Яма углублена в материк до 0,27 м. В погребении найдено женское захоронение с богатым инвентарем. Большая часть скелета не сохранилась. Сохранились лишь череп, фрагменты таза и трубчатых костей. Судя по сохранившейся части скелета, погребенная располагалась в вытянутом на спине положении и ориентирована головой на запад. На правом предплечье был найден бронзовый браслет с несомкнутыми и слегка раскованными или расплющенными концами (рис. 1, 8). Подобные браслеты были найдены в позднесарматских погребениях Дербеневского и Салиховского могильников в Южном Приуралье (Пшеничнюк, 1992. Рис. 6, 5,9; Боталов, Гуцалов, 2000. С. 134). Около правого предплечья были найдены остатки деревянной шкатулки (?), поверх которой лежало бронзовое зеркало. Под зеркалом, в коробочке находился деревянный двусторонний гребень (рис. 1, 9). Около этого вещевого комплекса была найдена бронзовая каплевидная орнаментированная подвеска.

Оба кургана, исходя из особенностей погребального обряда, найденного в насыпях и погребениях инвентаря, датируются позднесарматским временем II-III вв. н.э. Примечательным является наличие большого количества керамики в насыпи кургана № 25, что связано, вероятнее всего, с совершением определенных культово-ритуальных действий.

Таким образом, в результате работ полевого сезона 2018 г., учитывая проведенные исследования в предшествующие годы, получены данные, на основании которых предварительно можно предполагать, что большие курганы некрополя (исследованные в 2016-2017, 2019 гг.) хронологически и типологически относятся к памятникам «филипповского» круга и находят близкие 
параллели с курганами известного могильника Филипповка 1. Они имеют сходную организацию подкурганного пространства, планиграфию, архитектуру курганных сооружений, устройство могильных ям и погребальный инвентарь. Что касается группы малых курганов, как показали исследования 2017-2018 гг., они не связаны напрямую с большими курганными сооружениями и относятся к другому культурно-хронологическому горизонту. Исходя из погребального обряда, вещевых комплексов, характерных следов искусственной деформации черепов, дата их сооружения относится к позднесарматскому времени (II-III вв. н.э.) и определяет верхнюю хронологическую границу некрополя.

\section{ЛИТЕРАТУРА}

Боталов С.Г., Гуиалов С.Ю., 2000. Гунно-сарматы Урало-Казахстанских степей. Челябинск: Рифей. 265 с.

Малашев В.Ю., Яблонский Л.Т., 2008. Степное население Южного Приуралья в позднесарматское время: по материалам могильника Покровка 10. М.: Восточная литература. 365 с.

Мошкова М.Г., 1989. Позднесарматская культура // Степи европейской части СССР в скифо-сарматское время / А.И. Мелюкова (отв. ред.). М.: Наука. С. 191-202.

Мошкова М.Г., 2009. Анализ сарматских погребальных памятников II - IV вв. до н.э. // Статитстическая обработка погребальных памятников Азиатской Сарматии. Вып. IV. Позднесарматская культура // отв. ред. И.М. Гарскова. М.: Восточная литература. С. 21-162.

Скрипкин А.С., 1984. Нижнее Поволжье в первые века нашей эры. Саратов: Изд-во Саратовского университета. 150 с.

Сиротин С.В., Богачук Д.С., 2018. Погребальные конструкции курганов 2, 5 некрополя эпохи ранних кочевников «Высокая Мо- 
гила - Студеникин Мар» в Южном Приуралье // «Маргулановские чтения - 2018. Духовная модернизация и археологическое наследие». Сборник материалов Международной научно-практической конференции (19-20 апреля, 2018). Алматы-Актобе. С. 343-348.

Сиротин С.В., Богачук Д.С., Окороков К.С., 2018. Курганная группа «Богатырские могилки» № 4 (Оренбургская область, Оренбургский район) // Города, селища, могильники. Раскопки 2017. Материалы спасательных археологических исследований / А.В. Энговатова (отв. ред.). М.: Институт археологии РАН. Т. 25. С. 334-339.

Пшеничнюк А.Х., 1992. Дербеневский курганный могильник позднесарматского времени в Западном Приуралье // Проблемы хронологии сарматской культуры / А.С. Скрипкин (отв. ред.). Саратов: Изд-во саратовского университета. С. 67-84.

Пшеничнюк А.Х., 1983. Культура ранних кочевников Южного Урала. М.: Наука. 199 с.

Пшеничнюк А.Х., Рязапов М.Ш., 1976. Темясовские курганы позднесарматского времени на юго-востоке Башкирии // Древности Южного Урала / ред. Кузеев Р.Г., Мажитов Н.А., Пшеничнюк А.Х. Уфа: БФАН СССР. С. 132-149.

\section{СВЕДЕНИЯ ОБ АВТОРАХ:}

Сиротин Сергей Викторович, к.и.н., Институт археологии РАН, Москва, Россия, e-mail: sirotinsv70@mail.ru

Богачук Дарья Сергеевна, Института археологии РАН, Москва, Россия, e-mail: BogachukDS@iaran.ru

Окороков Константин Сергеевич, Института археологии РАН, Москва, Россия, e-mail: okorokov.arx@mail.ru 

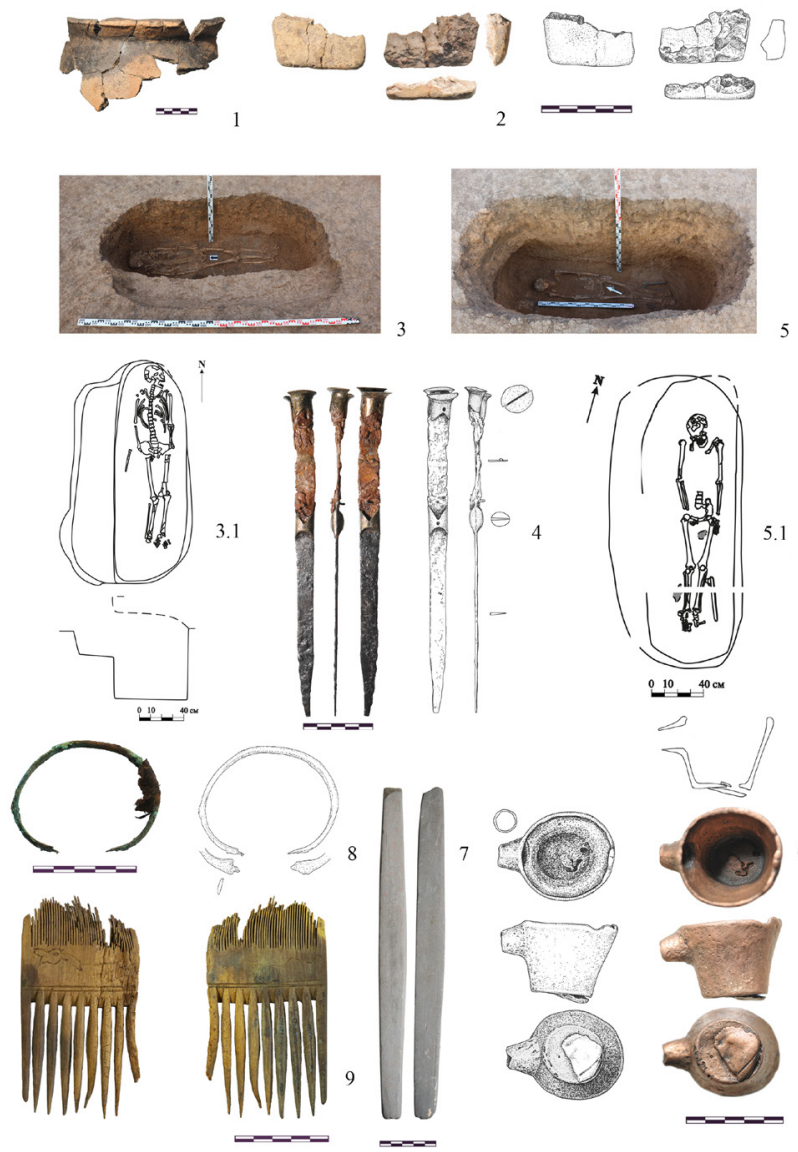

Рис. 1. Курганный могильник «Высокая Могила - Студеникин Мар». Группа «Богатырские Могилки». Курган 7: 1 - насыпь кургана, фрагменты сосуда № 1; 2 - насыпь кургана, фрагменты сосуда № 1; 3 - 3.1 - погребение 1; 4 - железный нож из погребения 1; 5 - 5.1 - погребение 2; 6 - бронзовый сосудик из погребения 2; 7 - каменный оселок. Курган 25: 8 - бронзовый браслет из погребения 2; 9 - деревянный гребень из погребения 2. 


\section{М.Ю. Трейстер}

\section{Алебастровая статуэтка из сарматского погребения в Южном Приуралье}

Резюме. Рассматривается уникальная алебастровая фигурка, обнаруженная в детском погребении № 1 кургана № 3/1995 могильника Нижняя Павловка-I, которое датируют достаточно ординарным погребальным инвентарем в рамках конца I в. до н.э. - начала II в. н.э. Публикуемая фигурка отличается от примитивных женских фигурок, как правило, из мела, найденных в сарматских погребениях, не только материалом и техникой изготовления, но и качеством работы. Изначально установленная на постаменте фигурка с украшениями, характерными как для культуры Парфии и Хорезма, так и кочевников Сарматии II-I вв. до н.э., вряд ли может датироваться позднее этого времени. Парфянское происхождение фигурки маловероятно, учитывая стиль изображения. Сложнее обстоит вопрос с возможностью изготовления такой фигурки в Хорезме, но среди известных мне среднеазиатских фигурок нет образцов с подобным положением рук. Соответственно, нельзя исключать и работу профессионального мастера специально с учетом вкусов заказчика.

Ключевые слова: Азиатская Сарматия, Южное Приуралье, Хорезм, Парфия, женские фигурки из алебастра, многовитковые браслеты и гривны. 


\section{Yu. Treister}

\section{Alabaster figurine from a Sarmatian burial in the Southern Urals}

Abstract. A unique alabaster figurine discovered in the children's burial No. 1 of the Burial-mound No. 3/1995 of the Nizhnyaya Pavlovka-I Burial-ground, which is dated by a fairly ordinary funeral inventory in frames of the late $1^{\text {st }}$ c. BC. - early $2^{\text {nd }}$ c. AD. The figurine discussed varies from the primitive female figures made, as a rule, from chalk, found in Sarmatian burials, not only by the material and manufacturing technique, but also by the quality of its execution. Initially mounted on a pedestal, a statuette with ornaments characteristic to the culture of Parthia and Chorasmia, as well as the nomads of Sarmatia of the $2^{\text {nd }}-1^{\text {st }} c$. BC, can be hardly dated later. The Parthian origin of the figure is unlikely, given its stylistic features. More difficult is the question of the possible Chorasmian origin, but among the Central Asian figurines I do not know examples with a similar position of the hands. Accordingly, one cannot exclude the work of a professional craftsman, who created the piece taking into account the tastes of the customer.

Key Words: Asian Sarmatia, South Urals, Chorasmia, Parthia, female alabaster figurines, multi-turn bracelets and torcs.

Во впускном погребении № 1 кургана № 3/1995 могильника Нижняя Павловка-I, которое датировалось достаточно ординарным погребальным инвентарем в рамках конца I в. до н.э. - начала II в. н.э., и содержало погребение ребенка 7-9 лет, вероятно девочки (Богданов, 1998. С. 45-47, 49-52. Рис. 2-5; 2018. С. 110-112. Рис. 4-5), была сделана уникальная находка, опубликованная автором раскопок (Богданов, 1998. С. 46, 50. Рис. 3; 2018. С. 111-112. 
Рис. 5; С. 122-130). Это фигурка из штука (алебастра) стоящей обнаженной широкоплечей молодой женщины или девушки со сведенными под грудью руками, со следами раскраски черной краской головного убора, глаз и лобка. Непропорционально короткие ноги согнуты в коленях; ступни не проработаны - снизу сведенные ноги разделены канавкой треугольного профиля. Спина и ягодицы уплощены. Округлым отверстием показан пупок в нижней части живота. Узкие миндалевидные глаза и брови выделены очень рельефно, нос уплощен (рис. 1-3)*

В сарматских погребениях Подонья, Поволжья и Южного Приуралья ранне- и среднесарматского времени, преимущественно погребениях девочек и молодых женщин, неоднократно были найдены примитивные женские антропоморфные фигурки, как правило, вырезанные из мела, реже и кости (Богданов, 1998. С. 46-47; 2018. С. 122-125; Скрипкин, 2010. С. 66-74), однако, публикуемая фигурка отличается от них не только материалом, техникой изготовления, но и большей детализацией изображения - совершенно очевидно, что она изготовлена профессиональным мастером. С некоторыми статуэтками из сарматских погребений (Богданов, 1998. С. 44-45. Рис. 1, 1; Скрипкин, 2010. Рис. 74, 2, 2-3) ее сближает лишь положение рук в горизонтальной плоскости под грудью.

Алебастр (штук) широко использовался в Греко-Бактрии и в Парфии, не только в качестве материала архитектурного декоpa (Mathiesen, 1992. P. 177-182. Nos. 99-134), но для изготовления

\footnotetext{
* Оренбург, Губернаторский историко-краеведческий музей, инв. № Ором 17703/88. Автор выражает искреннюю благодарность О.А. Халяпиной за возможность работы с комплексом погребения и С.В. Богданову за консультации. Представленная публикация выполнена в рамках проекта, финансируемого DFG и РГНФ «Формы и пути культурных контактов кочевников Азиатской Сарматии. Импорты в сарматских памятниках II в. до н. э. - III в. н. э.» (FL-334/15-1). Партнер проекта с российской стороны - Б.А. Раев.
} 
скульптур (Литвинскиц̆, 2010б. С. 239-269. Илл. 17-19) и статуэток (Parlasca, 1991. S. 51; Tallon, 1999. P. 229-243. Figs. 1-5; Kat. Mannheim, 2009. S. 310. Nr. 165; Литвинский, 2010а. С. 86-90. Рис. 1), а также элементов терракотовых фигурок. И элементы архитектурного декора, и статуэтки покрывались росписями. Парфянские алебастровые статуэтки часто имели дополнительные украшения из цветного камня (вставные глаза), реже из золота (серьги, гривна), как датируемая I в. до н.э. - I в. н.э. фигурка из погребения некрополя Хиллах в Вавилоне (Tallon, 1999, Р. 229243. Fig. 1; Bahrani, 2017. Р. 327-328. Fig. 14.4). Как правило, алебастровые фигурки из Месопотамии представляли собой обнаженную стоящую (Tallon, 1999. P. 229-243. Figs. 1-5; Cat. New York, 2000. P. 118-119. Fig. 91) или полулежащую (Cat. New York, 2000. P. 118-119. Fig. 90; Kat. Mannheim, 2009. S. 310. Nr. 165; Bahrani, 2017. P. 328-329. Figs. 14.7-8) женскую фигуру. Они выполнены в традициях эллинистического искусства.

С этой точки зрения фигурка из Нижней Павловки не имеет ничего общего с парфянскими алебастровыми статуэтками, ни по манере изображения, ни по головному убору и другим атрибутам, хотя положение рук, согнутых в локтях и положенных одна на другую под грудью, и напоминает положение рук парфянских костяных (Boucharlat, Haerinck, 1994. P. 193. Nos. 9-10; P. 194. Figs. 9-10), терракотовых (Curtis, 1979. P. 311, 312. Pl. 3 , внизу справа), изготовленных из слоновой кости (Bahrani, 2017. P. 338, 340. Fig. 14.19) фигурок, а также изображений женских фигур на граффити из Дура-Европос (Downey, 2003. P. 85. Fig. VIII). Близким образом трактованы руки статуэток и плакеток из штука первых веков н.э. из Северной Сирии, но в положенной сверху руке, как правило, находится чаша (Parlasca, 1991. S. 49-53. Taf. $20 ; 21, a . c)$. Скорее можно говорить о близости к выполненным в аналогичной технике статуэткам из Хорезма. Так, среди находок 
с городища Кой-Крылган-Кала имеется фрагмент обнаженной сидящей статуэтки с раскраской, от которой сохранилась только нижняя часть (Воробъева, 1967. С. 207. № 4. Табл. XXXIII, 3). На фрагменте другой женской фигурки с отбитой головой и руками на шее проработана гривна (Воробъева, 1967. С. 208. № 7).

Особенностью фигурки из Нижней Павловки является головной убор в форме низкого усеченного конуса (сужающегося кверху), из-под которого на затылочную часть спускается прическа. В центральной части верхней поверхности убора имеется углубление с вертикальными стенками округлой в плане формы. В узком канте на верхнем крае головного убора слева высверлено небольшое округлой формы углубление, возможно для вставки украшения из органического материала (рис. 1, 2; 2, 3; 3, 3). Поскольку отверстие расположено не по центральной оси статуэтки и внутри него нет никаких следов коррозии трудно предполагать его иное функциональное назначения, например, для крепления диска зеркала, как в находке из Соколовой Могилы (Ковпаненко, 1986. С. 66-72. Рис. 70-73). Головной убор фигурки очень необычен и аналогии ему мне не известны.

Не менее примечательно и то, что шея персонажа украшена спиральной 4-витковой гривной, запястья рук - 5-витковыми спиральными браслетами, щиколотки ног - 4-витковыми спиральными браслетами.

Изображения многовитковых гривен, в некоторых случаях с зооморфными окончаниями, мы встречаем на мужских портретах на датированных около середины I в. до н.э. фресках из Акхакан-Калы в Хорезме (Yagodin et al., 2009. P. 20. Figs. 6, 7, 10, 13; Kidd, 2011. P. 246-249. Fig. 5; Kidd et al., 2012. P. 112-113. Fig. 5.5). На терракотовых женских статуэтках из Кой-Крылган-Калы также встречаются изображения многовитковых гривен, на которые указывает Ф. Кидд (Kidd, 2011. Р. 248. Note 101), хотя, судя 
по описаниям терракот в публикации, лишь в одном случае издатели уверенно интерпретируют изображение как 4-витковую гривну (Воробъева, 1967. С. 180. Табл. XXVII, 19).

Подобные же многовитковые гривны изображаются на портретах парфянских царей на монетах, датирующихся преимущественно I в. до н.э. (Yagodin et al., 2009. Р. 20: 127 г. до н.э. 2 г. н.э.; cp. Kidd et al., 2012. Р. 113: ок. 88 г. до н.э. - 2 г. н.э.) Аналогичная золотая гривна украшает алебастровую статуэтку из Вавилона (Tallon, 1999. Р. 229-243. Fig. 1).

Спиральные гривны и браслеты изображены у воинов на каменных стелах из святилищ Байте III и Карамунке на плато Устюрт (Самашев и др., 2007. С. 233-235, 242-243, 249, 255, 257, 259-261) и у персонажа на фаларе из Янчокракского клада (Mordvinceva, 2001. S. 79. Nr. 69. Taf. 37). Известны реальные находки таких золотых гривен и браслетов в погребениях кочевников как Азиатской Сарматии, так и Прикубанья II-I вв. до н.э. (Трейстер, 2007. С. 98-99, 141-142). В это же время была распространена мода ношения ножных, как правило, многовитковых браслетов, причем как в античных городах Малой Азии и Северного Причерноморья, так и у кочевников (Трейстер, 2007. С. 150-151).

Есть основания предполагать, что изначально фигурка была закреплена на постаменте. Нижние части ног не проработаны - ступни отсутствуют. Сами ноги сведены и сходятся на конус ниже браслетов. Снизу на торце - продольная канавка треугольного профиля (рис. 1, 3).

Таким образом, украшения на рассматриваемой алебастровой фигурке отражают реалии, характерные как для культуры Парфии и Хорезма, так и кочевников Сарматии II-I вв. до н.э., что делает маловероятной ее датировку более поздним временем. Вопрос о месте производстве фигурки остается открытым. Мне 
трудно представить себе, чтобы кочевники овладели техникой изготовления фигурок из штука, тем более что все известные фигурки идолов из погребений кочевников Азиатской Сарматии, представляют собой довольно примитивные изделия, вырезанные, как правило, из мела. Парфянское происхождение фигурки маловероятно, учитывая стиль изображения. Сложнее обстоит вопрос с возможностью изготовления такой фигурки в Хорезме. Среди известных мне среднеазиатских терракотовых статуэток, изображающих стоящую обнаженную женскую фигуру, я не знаю образцов с подобным положением рук. Как правило, левая рука таких статуэток опущена вниз и положена кистью на бедро или лобок (Воробьева, 1967. С. 182. Рис. 71; С. 186. Табл. XXVII, 25; XXIX, $40-$ 41; Двуреченская, Новиков, 2013. С. 498-499, 532-533. № 4-5; С. 545. № 33 - с зеркалами в руках; С. 556. № 57). Соответственно, нельзя исключать в данном случае и работу профессионального мастера специально с учетом вкусов заказчика. Продолжать спекуляции на эту тему с учетом того, что рассматриваемый памятник был найден в рядовом детском погребении, бессмысленно, тем более, что не исключено, что на момент погребения (если действительно захоронение относится к I или даже началу II в. н.э., как полагает автор раскопок, фигурка уже была антикварным предметом, с повреждениями и утраченным постаментом.

\section{ЛИТЕРАТУРА}

Богданов С.В., 1998. Идолы и амулеты сарматских погребений Урало-Казахстанских степей // Уфимский археологический вестник. Вып. 1. С. 44-52.

Богданов С.В., 2018. Культурно-хронологические комплексы скифо-сарматской эпохи I Нижнепавловского курганного могильника в степном Приуралье // Stratum plus. № 3. С. 103-133. 
Воробъева М.Г., 1967. Терракоты, рельефы и алебастровые статуэтки // Кой-Крылган-кала - памятник культуры древнего Хорезма IV в. до н.э. - IV в. н.э. / Ред. С.П. Толстов, Б.И. Вайнберг. М.: Наука. С. 173-214.

Двуреченская Н.Д., Новиков С.В., 2013. Терракотовая пластика Маргианы (по материалам Среднеазиатской археологической экспедиции 1980-2003 гг.) // Scripta antiqua. Вып. 3. С. 483-573.

Ковпаненко Г.Т., 1986. Сарматское погребение I в. н.э. на Южном Буге. Киев: Наукова думка.

Литвинский Б.А., 2010а. Парфяно-бактрийские перекрестки // Проблемы истории филологии, культуры. № 1. С. 84-103.

Литвинский Б.А., 2010б. Храм Окса в Бактрии (Южный Таджикистан). Т. 3. Искусство. Художественное ремесло. Музыкальные инструменты. М.: Восточная литература.

Самашев 3., Кушербаев К., Аманшаев Е., Астафьев А., 2007. Сокровища Устюрта и Манкыстау. Алматы: изд-во не указано.

Скрипкин А.С., 2010. Сарматы и Восток. Волгоград: Изд-во ВолГУ.

Трейстер М.Ю., 2007. Торевтика и ювелирное дело в Северном Причерноморье. II в. до н.э. - II в. н.э. (эллинистическая традиция) // Мордвинцева, В.И., Трейстер М.Ю. Произведения торевтики и ювелирного искусства в Северном Причерноморье. II в. до н.э. - II в. н.э. Том 1. Симферополь-Бонн: Тарпан. С. 15194.

Bahrani Z., 2017. La Mesopotamia. Arte e architettura. Torino: Giulio Einaudi editore s.p.

Boucharlat R., Haerinck E., 1994. Das Ewig-Weibliche: Figurines en os d'époque parthe de Suse // Iranica Antiqua. Vol. 29. P. 185-199.

Cat. New York, 2000. The Year One. Art of the Ancient World. East and West / E. J. Milleker (ed.). New York: Metropolitan Museum of Art; Yale University Press. 
Curtis J., 1979. Loftus' Parthian Cemetery at Warka // Akten des VII. Internationalen Kongresses für Iranische Kunst und Archäologie, München 7-10 September 1976 (Archäologische Mitteilungen aus Iran Ergänzungsband 6) Berlin: D. Reimer. P. 309-317.

Downey S.B., 2003. Terracotta Figurines and Plaques from Dura-Europos. Ann Arbor: Univ. of Michigan Press.

Kat. Mannheim, 2009. Alexander der Grosse und die Öffnung der Welt / S. Hansen, A. Wieczorek, M. Tellenbach (Hrsg.). Regensburg: Schnell + Steiner.

Kidd F., 2011. Complex Connections: Figurative Art from Akchakhan-Kala and the Problematic Question of Relations between Khorezm and Parthia // Topoi. T. 17.1. P. 229-276.

Kidd F., Negus Cleary M., Baker Brite E., 2012. Public vs. Private. Perspectives on the Communication of Power in Ancient Chorasmia // Regimes and Revolutions: Power, Violence, and Labor in Eurasia Between the Ancient and the Modern / C. Hartley, G. Bike Yazıcıoğlu, A.T. Smith (eds.). Cambridge: Cambridge Univ. Press. P. 91-121.

Mathiesen H.E., 1992. Sculpture in the Parthian Empire. A Study in Chronology. Aarchus: Aarhus Univ. Press.

Mordvinceva V.I., 2001. Sarmatische Phaleren (Archäologie in Eurasien 11). Rahden: Leidorf.

Parlasca K., 1991. Einige Meisterwerke syrischer Kleinkunst des Hellenismus und der frühen Kaiserzeit // Damaszener Mitteilungen. Bd. 5. S. 49-58.

Tallon F., 1999. Les rubis d'Ishtar: étude archéologique // Cornaline et pierres précieuses: la Méditerranée, de l'Antiquité à l'Islam. Actes du colloque organisé au musée du Louvre par le Service culturel, les 24 et 25 novembre 1995 / A. Caubet (ed.). Paris: La Documentation française. P. 229-243.

Yagodin V.N., Betts A.V.G., Kidd F., Baker Brite E., Khozhaniyazov G., Amirov S., Yagodin V.V., Fray G., 2009. Karakalpak-Australian 
Excavations in Ancient Chorasmia. An Interim Report on the Kazakly-yatkan Wall Paintings: the "Portrait" Gallery // Journal of Inner Asian Art and Archaeology. Vol. 4. P. 7-41.

\section{СВЕДЕНИЯ ОБ АВТОРЕ}

Михаил Юрьевич Трейстер, д.и.н., научный сотрудник, Германский археологический институт, Podbielskiallee 69-71, 14195 Berlin, Germany, mikhail.treister@dainst.de, mikhailtreister@ yahoo.de.

ORCID iD: 0000-0001-7451-3325 


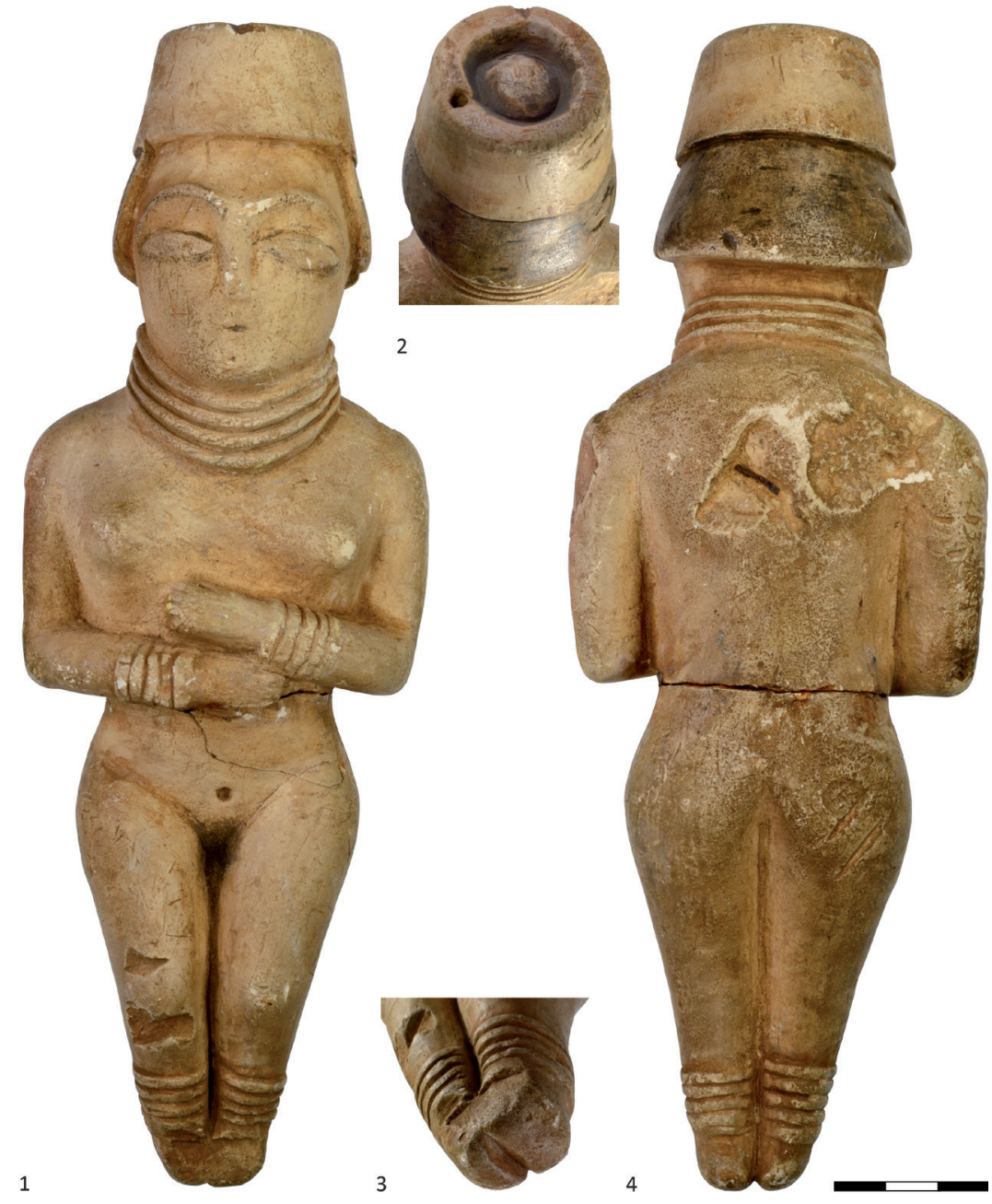

Рис. 1. Нижняя Павловка-І. Курган № 3/1995. Погребение № 1. Алебастровая статуэтка.

Оренбург, Губернаторский историко-краеведческий музей, инв. № Ором 17703/88. Фото М.Ю. Трейстера, 2015. 

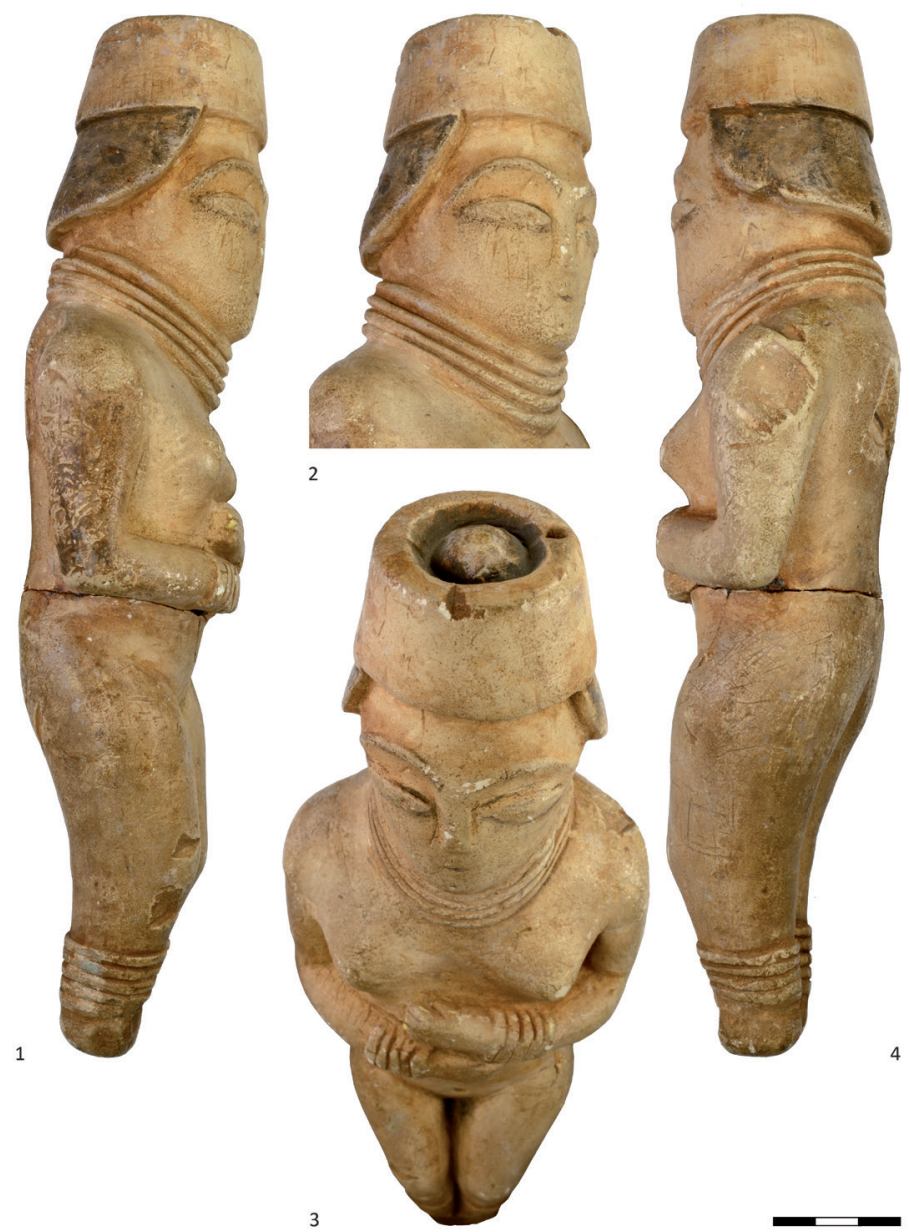

Рис. 2. Нижняя Павловка-I. Курган № 3/1995. Погребение № 1. Алебастровая статуэтка.

Оренбург, Губернаторский историко-краеведческий музей, инв. № Ором 17703/88. Фото М.Ю. Трейстера, 2015. 

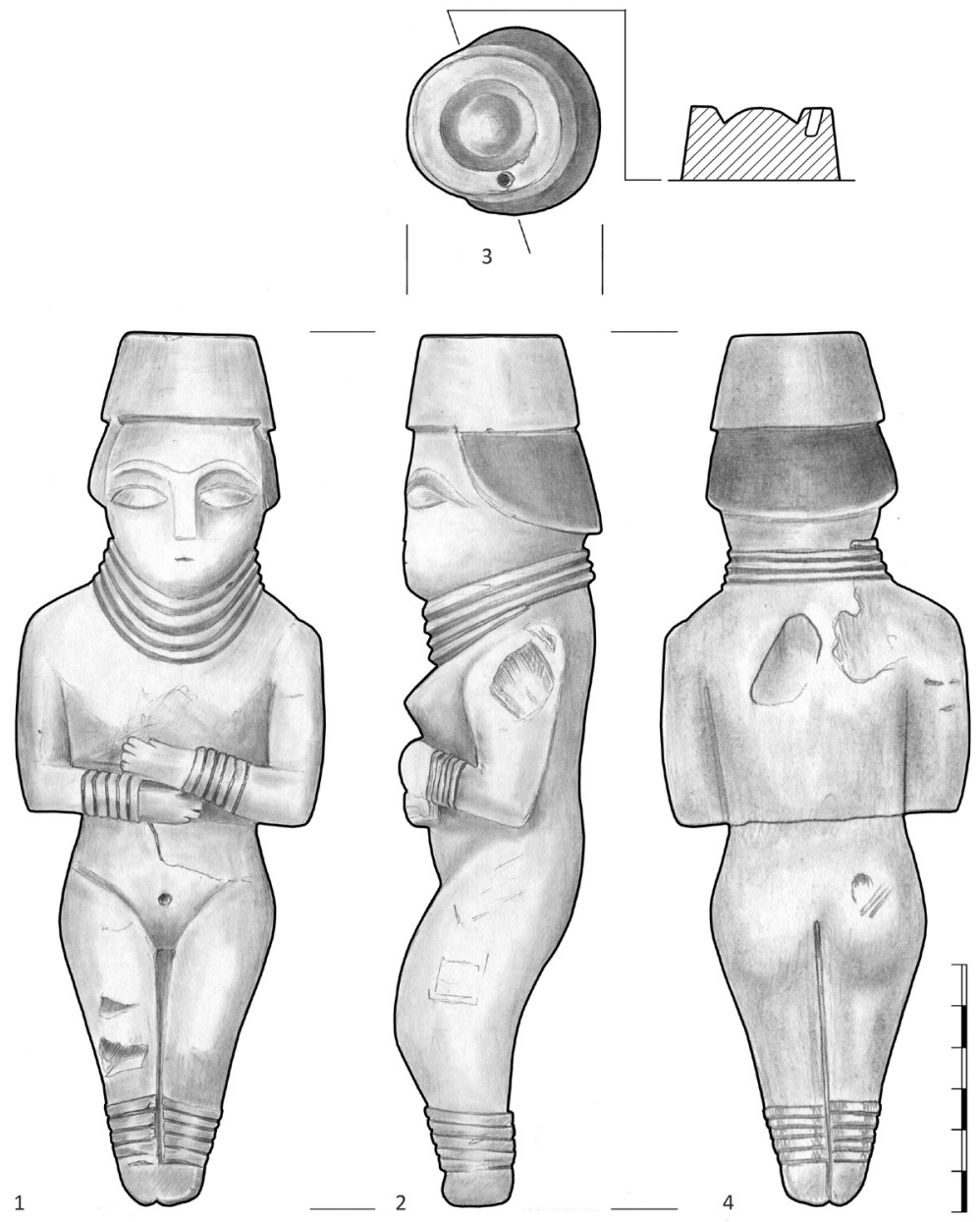

Рис. 3. Нижняя Павловка-І. Курган № 3/1995. Погребение № 1. Алебастровая статуэтка.

Оренбург, Губернаторский историко-краеведческий музей, инв. № Ором 17703/88. Рисунки Н.Е. Беспалой †, 2015. 
Early nomads of the Southern Urals and the Lower Volga region. Materials of the panel discussion "Archeology of the Early Nomads of the Eurasian Steppe: Current Problems and Prospects for Their Solution". To the anniversary of M. G. Moshkova / The Institute of Archaeology of the RAS. - Moscow : MAKS Press, 2020. -240 p.

ISBN 978-5-317-06506-5

https://doi.org/10.25681/IARAS.2020.978-5-317-06506-5

The collection contains materials of the Round Table with international participation "Archeology of the Early Nomads of the Eurasian Steppe: Current Problems and Prospects for Their Solution". The panel discussion took place at the Institute of Archeology of the Russian Academy of Sciences on November 12-13, 2019. The articles consider issues related to the controversial issues of the history and archeology of the early nomads of the Southern Urals and the Lower Volga region of the Scythian and Sarmatian eras, as well as represent new materials from field research in the context of cultural genesis, burial rituals, chronology, etc.

The publication is intended for specialists in the field of archeology and history.

Key words: archaeological culture, early nomads, Scythian, Savromat and Sarmatian culture, South Urals, Lower Volga region, Ciscaucasia. 
Научное издание

\section{РАННИЕ КОЧЕВНИКИ ЮЖНОГО УРАЛА И НИЖНЕГО ПОВОЛЖЬЯ}

Материалы круглого стола

«Археология ранних кочевников евразийской степи: актуальные проблемы и перспективы их решения» К юбилею доктора исторических наук М. Г. Мошковой

Издательство «МАКС Пресс»

Главный редактор: E. M. Бугачева

Компьютерная верстка, обложка: $A$. В. Кононова

Подписано в печать 09.12.2020 г. Формат 60х90 1/16. Усл. печ. л. 15,0.

Тираж 100 экз. Изд. № 193.

Издательство ООО «МАКС Пресс» Лицензия ИД N00510 от 01.12.99 г.

119992, ГСП-2, Москва, Ленинские горы,

МГУ им. М. В. Ломоносова, 2-й учебный корпус, 527 к.

Тел. 8(495) 939-3890/91. Тел./Факс 8(495) 939-3891

Отпечатано в полном соответствии с качеством предоставленных материалов в ООО «Фотоэксперт»

115201, г. Москва, ул. Котляковская, д.3, стр. 13. 